UNIVERSIDADE DE SÃO PAULO

FACULDADE DE FILOSOFIA, LETRAS E CIÊNCIAS HUMANAS

DEPARTAMENTO DE LINGUÍSTICA:

PROGRAMA DE PÓS-GRADUAÇÃO EM SEMIÓTICA E LINGUÍSTICA GERAL

SUELI MARIA RAMOS DA SILVA

Discurso de divulgação religiosa:

Semiótica e Retórica

\author{
V. 1 \\ Versão Corrigida
}

São Paulo

2011 


\section{Discurso de divulgação religiosa: Semiótica e Retórica}

Tese apresentada ao Programa de Pós-Graduação em Semiótica e Linguística Geral, do Departamento de Linguística Faculdade de Filosofia, Letras e Ciências Humanas da Universidade de São Paulo, para obtenção do título de Doutor em Linguística.

Área de Concentração: Semiótica e Linguística Geral Orientador: Profa. Dra.Norma Discini de Campos

Versão corrigida da tese: o exemplar original se encontra disponível no CAPH da FFLCH (Centro de Apoio à Pesquisa Histórica).

De acordo do orientador:

Profa. Dra. Norma Discini de Campos

V.1

São Paulo 
AUTORIZO A REPRODUÇÃO E DIVULGAÇÃO TOTAL OU PARCIAL DESTE TRABALHO, POR QUALQUER MEIO CONVENCIONAL OU ELETRÔNICO, PARA FINS DE ESTUDO E PESQUISA, DESDE QUE CITADA A FONTE.

Catalogação na Publicação

Serviço de Documentação do Sistema Integrado de Bibliotecas - SIBI

Faculdade de Filosofia, Letras e Ciências Humanas

RAMOS-SILVA, Sueli Maria.

Discurso de divulgação religiosa: semiótica e retórica / Sueli Maria Ramos da Silva; orientador Norma Discini de Campos - São Paulo, 2011.

$337 f$.

Tese (Doutorado- Programa de Pós-Graduação em Semiótica e Linguiística Geral. Área de Concentração: Semiótica e Linguística Geral) - Faculdade de Filosofia, Letras e Ciências Humanas.

1. Semiótica 2. Retórica 3. Estilo 4. Discurso religioso I. Título. 
Nome: RAMOS-SILVA, Sueli Maria

Título: Discurso de divulgação religiosa: Semiótica e Retórica

Tese apresentada ao Programa de Pós-Graduação em Semiótica e Linguística Geral, do Departamento de Linguística Faculdade de Filosofia, Letras e Ciências Humanas da Universidade de São Paulo, para obtenção do título de Doutor em Linguística.

Área de Concentração: Semiótica e Lingüística Geral

Aprovado em: 09 de março de 2012

BANCA EXAMINADORA

Prof. Dr. Norma Discini de Campos (Presidente) Instituição FFLCH-USP

Julgamento Assinatura

Prof. Dr. Sirio Possenti (Titular) Instituição UNICAMP - Externo

Julgamento Assinatura

Prof. Dr. Jean Cristtus Portela (Titular)

Instituição UNESP - Externo

Julgamento Assinatura

Prof. Dr. Ivã Carlos Lopes (Titular)

Instituição FFLCH-USP

Julgamento

Assinatura

Prof. Dr. Waldir Beividas

Instituição FFLCH-USP

Julgamento Assinatura 
À Norma Discini, mestra singularíssima, por me impulsionar sempre a ir além daquilo que eu julgava ser capaz.

À minha família, pelo amor e dedicação incondicional com o qual acompanharam e incentivaram minha trajetória acadêmica.

Ao meu amado Alberto Benicio, por todo apoio, carinho, zelo, paciência e companheirismo constantes. 


\section{AGRADECIMENTOS}

À Profa. Dra. Norma Discini de Campos, pela sua extraordinária competência, atenção, apoio e acompanhamento criterioso durante todo o processo de orientação.

Aos Profs. Drs. Ivã Carlos Lopes e Waldir Beividas, pelos preciosos apontamentos apresentados, tanto no exame de qualificação, quanto em toda minha trajetória acadêmica.

Aos Profs. Drs. Jean Cristtus Portela e Matheus Nogueira Schwartzmann por tantos apontamentos valiosos, pela parceria e ótima companhia em inúmeros Congressos de Semiótica.

Aos Profs. Drs. de Graduação e Pós-Graduação do Departamento de Linguística da Universidade de São Paulo, por terem sedimentado as bases sólidas necessárias à realização da minha trajetória acadêmica.

Aos funcionários do Departamento de Lingüística, Érica, Robson e Ben Hur, pela presteza no atendimento aos alunos.

À Juliana Attie, pela revisão cuidadosa deste trabalho e pelas valiosas sugestões apresentadas.

À Juliana Pacheco e Bruna Paola Zerbinatti, pelo zelo com o qual me auxiliaram nas questões referentes à revisão e tradução.

Aos amigos e colegas do Programa de Pós Graduação em Semiótica e Linguística Geral, pelo apoio e incentivo. Muitos poderiam aqui ser nomeados, dentre esses, não há como ressaltar: Eliane Soares de Lima, Carolina Tomasi, Bruna Paola Zerbinatti, Cíntia Marinho, Taís de Oliveira, Lidia Lima da Silva, Sonia Lindblom, Ivanete Belém do Nascimento, Natalia Guirado, Alexandre Marcelo Bueno, Oriana Fulaneti entre tantos outros.

Ao Conselho Nacional de Desenvolvimento Científico e Tecnológico (CNPQ) pela concessão da bolsa de doutorado e pelo apoio financeiro necessário à realização desta pesquisa. 
Mosaicos são obras de arte. São feitos com cacos. [...] Muitos são os mosaicos que podem ser feitos com um monte de cacos. Muitas são as músicas que podem ser feitas com as doze notas da escala cromática. [...] Cada religião é um mosaico, um jeito de ajuntar os cacos. Cada religião é uma sonata: uma rede de temas. Escolhi os cacos de que mais gosto para fazer o meu mosaico, o meu livro de estórias, a minha sonata, o meu altar à beira do abismo. 
RAMOS-SILVA, Sueli Maria. Discurso de divulgação religiosa: Semiótica e Retórica. 2011. 337f. Tese (Doutorado) - Faculdade de Filosofia, Letras e Ciências Humanas, Universidade de São Paulo, São Paulo, 2011.

Amparados no desenvolvimento da noção semiótica de estilo com a operacionalização da noção de éthos proposta por Discini (2004b), buscamos evidenciar nosso ponto de vista que procura expandir os desenvolvimentos ora apresentados, mediante a proposição de uma revitalização da retórica, associando-a ao ponto de vista tensivo da semiótica. Nessa direção procuramos agregar a noção de estilo enquanto éthos, tom de voz, caráter e corporalidade depreensível de uma totalidade de discursos (Discini, 2004b), ao ponto de vista tensivo proposto por Zilberberg (2006a) em referência às noções de estilo ascendente e descendente estabelecidas pelo autor. Pretendemos, dessa forma, delinear de forma mais abrangente o modo de presença dos enunciados enfeixados pelo discurso de divulgação religiosa e, por conseguinte, do próprio discurso religioso. A partir da observação das recorrências dos mecanismos de construção do sentido dos enunciados reunidos por meio desta tese procuramos estabelecer uma distinção entre os três níveis de práticas no que concerne ao discurso religioso: a) discurso fundador; b) discurso de fidelização religiosa; c) e discurso de divulgação religiosa. Propomos delinear uma tipologia dos discursos de divulgação religiosa, relacionando-a aos diferentes modos segundo os quais se processualiza o paradigma da crença preconizado por Zilberberg (2006a). Destacamos o caráter inovador da tipologia proposta, na medida em que a realizamos, tendo por princípio o enunciatário almejado por tais discursos. Procedemos, assim, ao estabelecimento de cinco cenas enunciativas diferenciadas: a) divulgação religiosa especializada; b) divulgação religiosa instrucional; c) discurso de conscientização social; d) divulgação religiosa propagandista; e) divulgação religiosa midiática. Nosso trabalho espera contribuir com as perspectivas contemporâneas de retorno em direção à retórica mediante o estudo dos discursos de fundação, de fidelização e de divulgação religiosa, com o exame da própria esfera de circulação do sentido religioso, ou seja, com reflexões a respeito do discurso religioso, como enunciado, enunciação, éthos, estilo e aspecto.

Palavras-Chave: Semiótica tensiva; Retórica; estilo; éthos; discurso religioso. 
RAMOS-SILVA, Sueli Maria. Dissemination of religious discourse: semiotic and rhetoric. 2011. 337f. Tese (Doutorado) - PhD Degree - Faculdade de Filosofia, Letras e Ciências Humanas, Universidade de São Paulo, São Paulo, 2011.

Our aim in this thesis is to show our point of view that seeks to expand the developments presented here, by proposing a revival of rhetoric and association, associating these ideas to the tensive point of view of semiotics. Our work is supported by the development of the Semiotic sense of style with the operationalization of the notion of ethos proposed by Discini (2004b). In this direction we seek to add the notion of ethos as style, tone, voice, character and corporeality which can be understood as a totality of discourses (Discini, 2004b), to the tensive point of view proposed by Zilberberg (2006a) in reference to the notions of upward and downward motions style set forth by the author. We propose, therefore, to delineate more fully the manner of presence of the enunciation set out to disseminate religious speech and therefore of their own religious discourse. From the observation of recurrences of the mechanisms of construction of meaning on the statements gathered by this thesis, we seek to distinguish between the three levels of practices with regard to religious discourse: a) founding discourse b) discourse of religious loyalty, c) and dissemination of religious discourse. We propose to outline a typology of dissemination of religious discourses, relating it to the different ways in which the paradigm of belief is processed according to Zilberberg (2006a). We'd like to highlight the innovative character of the proposed typology, as it has in principle to carry out the enunciatee pursued by such discourses. We proceed thus to the establishment of five different enunciative scenes: a) religious promotion specialist b) instructional religious promotion c) speech aiming at social conversion d) religious promotion aiming to advertize e) religious promotion media. Our work tries to contribute to the contemporary perspectives of return toward the Rhetoric study based on foundation speeches, religious loyalty and promotion by examining one's own sphere of circulation of the religious sense, that is, with reflections on the religious discourse, as stated, enunciation, ethos, style and appearance.

Keywords: Tensive semiotic; Rhetoric; style; ethos; religious discourse . 
RAMOS-SILVA, Sueli Maria. Discours de divulgation religieuse: sémiotique et rhétorique. 2011. 337f. Tese (Doutorado) - Faculdade de Filosofia, Letras e Ciências Humanas, Universidade de São Paulo, São Paulo, 2011.

En nous basant sur les développements de la notion de style et l'opérationnalisation de la notion d'éthos proposée par Discini (2004b), nous avons cherché à mettre en évidence notre point de vue qui entend étendre les développements existants moyennant la proposition d'une revitalisation de la rhétorique, en l'associant au point de vue tensif de la sémiotique. Dans cette perspective, nous nous sommes attachée à faire dialoguer les notions de style en tant qu'éthos, de ton de la voix et de caractère et corporalité extractibles d'une totalité de discours (Discini, 2004b), avec le point de vue tensif proposé par Zilberberg (2006a), et plus spécifiquement avec les notions de style ascendant et descendant développées par l'auteur. Nous proposons ainsi de délimiter de façon plus large le mode de présence des énoncés enchaînés par le discours de divulgation religieuse et, par conséquent, par discours religieux lui-même. À partir de l'observation de la récurrence des mécanismes de construction du sens des énoncés réunis au sein de cette thèse, nous avons cherché à établir une distinction entre les trois niveaux de pratiques concernant le discours religieux: 1. Discours fondateur; 2. Discours de fidélisation religieuse 3. Discours de divulgation religieuse. Nous proposons d'établir une typologie des discours de divulgation religieuse en les reliant aux différents modes selon lesquels se processualise le paradigme de la croyance avancé par Zilberberg (2006a). Nous avons mis en relief le caractère novateur de la typologie proposée à mesure que nous la réalisions, en tenant pour principe de différenciation l'énonciataire projeté par ces discours. Nous avons procédé ainsi à l'établissement de cinq scènes énonciatives différenciées: 1. Divulgation religieuse spécialisée; 2 . Divulgation religieuse institutionnelle ; 3. Discours de conversion sociale ; 4. Divulgation religieuse propagandiste ; 5. Divulgation religieuse médiatique. Avec ce travail, nous espérons avoir contribué, d'une part, aux perspectives contemporaines de réactualisation de la rhétorique en vue de l'étude des discours de fondation, de fidélisation et de divulgation religieuse et, d'autre part, à l'examen de la sphère de circulation du sens religieux, c'est-à-dire, aux réflexions portant sur le discours religieux comme énoncé, énonciation, éthos, style et aspect.

Mots-clés : Sémiotique tensive ; Rhétorique ; style ; éthos ; discours religieux. 


\section{Volume I}

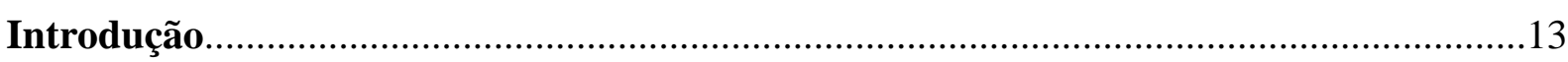

CAPÍTULO I. O Discurso Fundador na Esfera Religiosa..............................................23

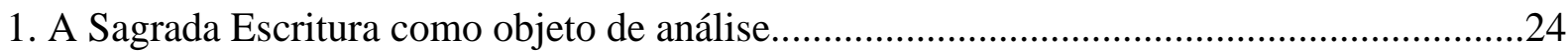

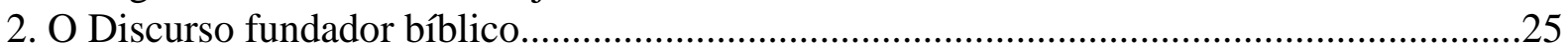

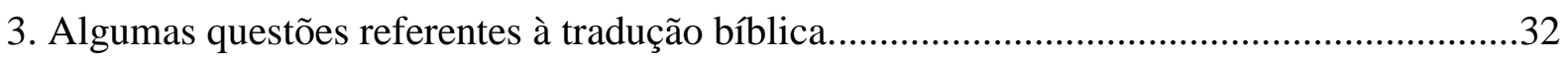

4. A Análise semiótica como princípio de método para uma exegese.....................................34

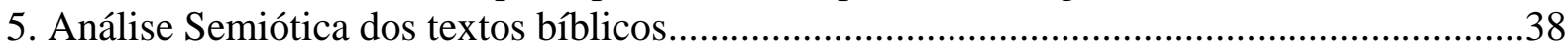

5.1 Análise do discurso fundador: a narrativa bíblica de Caim e Abel (Gn 4, 1-16) T2.........38

5.2 Análise Semiótica da Narrativa de Atos dos Apóstolos (At, 1-3)......................................46

\section{CAPÍTULO II. Discurso de fidelização religiosa: a experiência da Palavra na Prática}

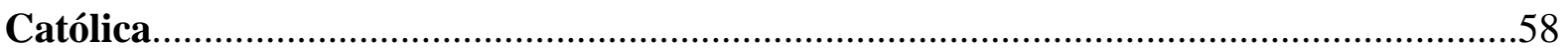

1. Estrutura do campo da prática de fidelização religiosa ....................................................59

2. Análise dos enunciados de fidelização religiosa.........................................................66

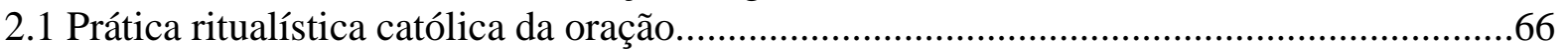

2.1.1 Ladainha de Nossa Senhora (ladainha lauretana): Análise Semiótica ..........................67

2.2. O Rito da Missa enquanto Prática Sacramental Católica................................................78

2.2.1 Folheto Litúrgico - Semanário Litúrgico-Catequético: Análise Semiótica.....................78

2.3 Prática Semiótica: Roteiro Preparatório de Confissão......................................................98

\section{CAPÍTULO III. A Totalidade Discursiva de Divulgação Religiosa..............................105}

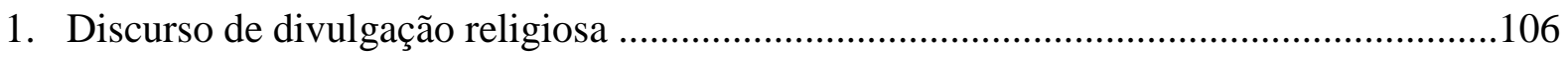

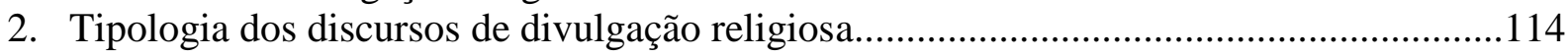

3. Análise dos enunciados de divulgação religiosa...............................................................119

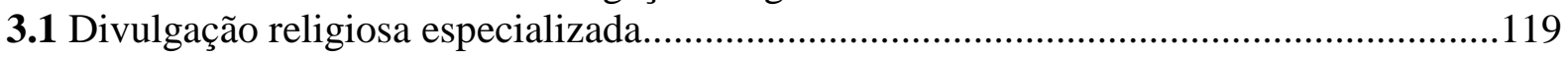

3.1.1 Análise semiótica da encíclica Evangelium Vitae .....................................................122

3.1.2 O éthos da divulgação religiosa especializada...........................................................133

3.1.3 Breves considerações sobre o éthos da divulgação religiosa especializada....................140

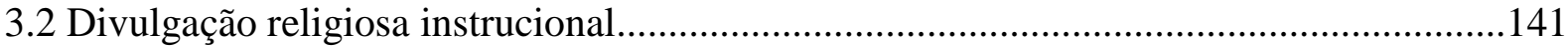

3.2.1 Análise de um gênero de divulgação religiosa instrucional: Compêndio do Catecismo da

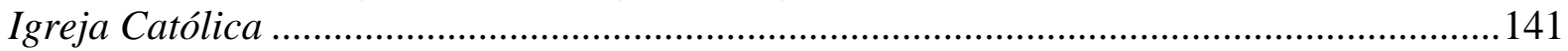

3.2.1.1 Análise de uma unidade "Capítulo Terceiro: A vida de oração" (T9)........................143

3.3 Divulgação $\quad$ para $\quad$ conscientização

3.3.1 Campanha da fraternidade (CF 2008): o sujeito divulgador na ação

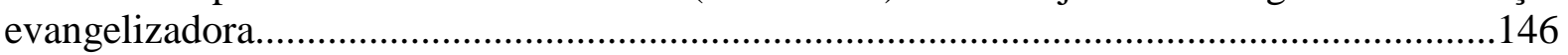

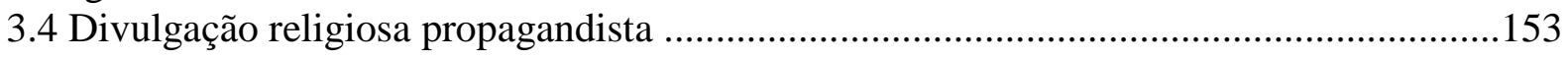


3.5. Divulgação religiosa midiática.

161

3.5.1. $\mathrm{O}$ sujeito divulgador no campo discursivo religioso

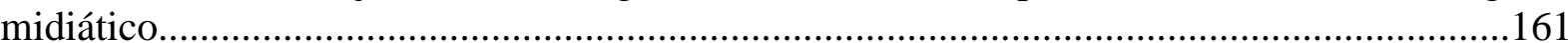

3.5.2 Relações polêmicas no campo de informação midiática............................................172

3.5.2.1 A polêmica do sujeito divulgador no campo discursivo religioso de informação midiática.

CAPÍtULO IV. A noção de éthos: fundamentos teóricos e bases para

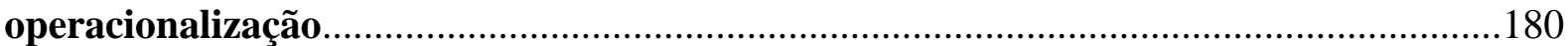

1. Semiótica e Retórica: fundamentos teóricos e bases para a operacionalização da noção de éthos

2. A operacionalização da noção de éthos no domínio religioso: a proposição de uma tipologia calcada no enunciatário

Conclusão

Vol. II Anexos 


\section{INTRODUÇÃO}

Os meios que dizem respeito à afetividade são, por um lado, o éthos, o caráter que o orador deve assumir para chamar a atenção e angariar a confiança do auditório e, por outro lado, o páthos, as tendências, os desejos, as emoções do auditório das quais o orador poderá tirar partido.

Olivier Reboul $^{1}$ 


\section{Problemáticas teóricas e analíticas}

Esta tese de doutorado tem por objetivo amplo estabelecer algumas reflexões no que diz respeito à concatenação entre o nível profundo e as instâncias enunciativas, tendo por base não só os princípios da semiótica greimasiana padrão, mas também o ponto de vista tensivo proposto pela semiótica. Procuramos desenvolver algumas interpelações concernentes à conexão entre o nível profundo da geração do sentido e a instância enunciativa, considerado o ponto de vista tensivo que, segundo Zilberberg (2006a), torna possível a articulação da tensividade com a retórica.

Partimos do exame de enunciados pertencentes ao domínio religioso, para o qual propomos três totalidades diferenciadas: a) discurso fundador; b) discurso de fidelização religiosa; c) discurso de divulgação religiosa.

A fundamentação teórica utilizada, a fim de que pudéssemos nos adequar aos objetivos do estudo proposto, consiste das bases da semiótica greimasiana de linha francesa, tomada também em seus desenvolvimentos tensivos por Zilberberg (2006a), e dos enfoques contemporâneos da Nova Retórica obtidos, principalmente, por meio dos trabalhos de Meyer (2007), Perelman e Olbrechts-Tyteca (2005). Ressaltamos a utilização de alguns conceitos advindos da Análise do Discurso Francesa, com a devida incorporação à teoria semiótica, dos quais vale realçar a noção de éthos ${ }^{2}$. Para isso, temos respaldo nos desenvolvimentos da noção de éthos elaborada por Maingueneau (2005b), quando o autor ultrapassa e expande o conceito retórico tradicional de éthos. Tomamos, ainda, a noção de éthos, associada à noção de estilo, tal como desenvolvida por Discini (2004b). O estilo, segundo Bakhtin (2003), refere-se às marcas linguísticas exigidas por um determinado gênero e que o caracterizam, e mais do que isso, conforme Discini (2004b), o estilo se refere ao éthos do gênero: o estilo do gênero.

No que diz respeito aos estudos referentes à noção de estilo que vêm sendo feitos no âmbito da semiótica e da Análise do Discurso de linha francesa, merecem destaque os estudos desenvolvidos por Discini (2004b), caracterizados pelo exame, basicamente, de duas ideias centrais: a) como estabelecer o estilo como "efeito de individuação de uma totalidade discursiva"; b) como determinar que "estilo é éthos, é corpo, é voz, é caráter de uma

\footnotetext{
${ }^{2}$ Notamos diferentes usos da palavra éthos nos diferentes domínios da linguagem nos quais o termo tem se consolidado. Dentre esses destacamos o emprego das notações "etos" pela retórica e "ethos" pela Análise do Discurso. Ressaltamos, entretanto, que optamos por usar a notação tal como tem sido utilizada pelos trabalhos dentro da teoria semiótica, na qual esta tese se situa, o que explica a utilização do termo éthos, grafado desta forma, ao longo de toda a tese.
} 
totalidade, sendo que o corpo da totalidade enunciada remete ao corpo do ator da enunciação" (DISCINI, 2004b, p. 28-30).

Buscamos depreender, por meio das relações entre enunciado e enunciação, o modo próprio de ver e perceber o mundo do sujeito inscrito em uma formação discursiva determinada. Mas a esse sujeito será acrescentada a investigação de seu corpo, voz, tom de voz e caráter, que é o éthos, princípio que orienta a noção de estilo e que ultrapassa o que Bakhtin (2003) propõe.

Faz-se necessário esclarecer a noção de formação discursiva empregada no decorrer desta tese. Consideramos a noção de formação discursiva, de acordo com a concepção da Análise do Discurso (AD), como "um conjunto de crenças, valores e ideais que materializa uma dada visão de mundo" (FIORIN, 2003, p. 32). O conceito de formação discursiva, "designa todo sistema de regras que funda a unidade de um conjunto de enunciados sóciohistoricamente circunscrito" (MAINGUENEAU, 2006, p. 68). Portanto, ao remetermos ao conceito de formação discursiva, consideramos que "no interior de um idioma particular, para uma sociedade, para um lugar, um momento definidos, só uma parte do dizível é acessível, que esse dizível constitui um sistema e delimita uma identidade" (MAINGUENEAU, 2005, p. 16).

Longe de qualquer posicionamento referente às ideias de uma formação discursiva considerada, ressaltamos a caracterização desta tese como um estudo dos procedimentos argumentativos empregados pelo enunciador, ao que corresponde a depreensão do éthos, do modo de dizer e de habitar o espaço social em que um determinado discurso se insere.

Desse modo, tomaremos e ampliaremos o diálogo proposto por Zilberberg (2006a) entre o ponto de vista tensivo da semiótica e a retórica. Esta será a base necessária para a articulação da noção de estilo e de éthos à semiótica tensiva.

Procuramos, mediante esse diálogo, fornecer os fundamentos para a operacionalização da noção de éthos, observado nos discursos de fundação, de fidelização e de divulgação religiosa.

Apoiados nos desenvolvimentos de Discini (2004b, p. 17), visamos desenvolver uma proposta de conceituação da noção de estilo, ao retomar as partes componentes do sistema retórico - inventio (busca de argumentos e de outros meios de persuasão), dispositio (ordenação dos argumentos), elocutio (estilo, conversão em linguagem do material das fases 
anteriores), actio (proferição efetiva do discurso) e memória (memorização do discurso) -, reexaminando-as sob o prisma da teoria semiótica.

Partiremos do princípio, tal como elencado pela autora (Idem, p.17), de que a linguagem humana constrói mundos e, além disso, é indissociável do homem, conforme afirma Benveniste (1976, p. 286): “é na linguagem e pela linguagem que o homem se constitui como sujeito; porque só a linguagem fundamenta na realidade, na sua realidade que é a do ser, o conceito de "ego"”. Assim, esse sujeito que faz e que constitui um determinado estilo será reconstruído na totalidade discursiva da totalidade dos enunciados em exame.

Aproximando a retórica da semiótica, será possível estudar as partes componentes do sistema retórico como o aparato teórico da semiótica greimasiana. A análise dos mecanismos sintáticos do discurso tornará admissível a operacionalização do conceito de éthos e das bases tensivas da teoria semiótica.

Dessa forma, o projeto que ora apresentamos vem se inscrever dentro da perspectiva daquilo que Greimas e Courtés (1986), no "Avant-Propos" da segunda edição do Dictionnaire Raisonné de la Théorie du Langage, estabeleceu como a "atração pela profundidade", mas em uma perspectiva diferenciada.

Ao pretendermos, portanto, alcançar algum aprimoramento epistemológico e técnico do modelo semiótico, nosso trabalho também tem como preocupação as questões recentes tomadas na perspectiva dos estudos do texto e do discurso, pautadas pela problemática da enunciação e da noção dos gêneros do discurso.

O dilema principal observado dentro do campo de estudos semióticos é a dissociação entre o que se considera uma semiótica greimasiana padrão e seus desdobramentos tensivos. Os desdobramentos tensivos da semiótica não se opõem à concepção da semiótica dita discursiva, embora procure atentar de maneira mais evidente a uma recategorização do nível profundo.

Sugerimos, dessa forma, por meio da tentativa de conexão entre esses dois desdobramentos da teoria semiótica, realizar uma iniciativa de aprimoramento do modelo, tal como se faz necessária aos trabalhos recentes produzidos no âmbito da teoria semiótica.

Tatit (1997, p. 35) alerta-nos para o fato de que a proliferação de trabalhos pautados pela análise de figuras passionais, que compreendem o estudo das modulações dos estados de alma do sujeito, por exemplo, o desespero, a indiferença, a cólera etc, empreendidos ao longo 
da década de 1980, incutem a "necessidade urgente de revisão das instâncias intermediárias e profundas do modelo gerativo".

Para a elaboração da referida proposição, apoiamo-nos nos desenvolvimentos da teoria, da forma como propõe Zilberberg (2006b), ao incluir a noção de afetividade na direção do processo de produção do sentido.

A escolha da problemática aqui proposta justifica-se também pelo fato de os conceitos ora escolhidos como determinantes dessa análise, isto é, a noção de afeto, aspecto, ritmo e presença, encontrarem-se longe de estar completamente definidos dentro da teoria semiótica. Essas categorias têm sido relegadas a um segundo plano, na maioria das vezes, em oposição ao privilégio concedido à narratividade oriunda de Propp.

Aliada a essa problemática teórica, acrescentamos a justificativa de análise do corpus religioso ora delimitado aos propósitos desta tese.

Tal como veremos no primeiro Capítulo desta tese, que tem como um de seus objetivos apresentar o histórico dos estudos bíblicos em semiótica, notamos que a inclusão dessas pesquisas no âmbito da semiótica greimasiana coincide com a publicação da obra $D u$ Sens (GREIMAS, 1970). Merece destaque a presença da semiótica no campo dos estudos exegéticos.

Entretanto, estudos referentes ao campo discursivo religioso no âmbito semiótico, no que diz respeito à noção de discurso de divulgação religiosa, bem como a um maior entendimento das noções de divulgação e de fidelização religiosa requerem maior aprofundamento e explicitação. A escassez de trabalhos que já teriam versado sobre esse tema, somada à presença cada vez mais constante do discurso religioso em todos os tipos de mídias contemporâneas foram determinantes para a escolha da temática desta tese.

Pesquisas relativas ao campo discursivo religioso, além de serem escassas, na maioria das vezes são restritas ao aspecto sociocultural, tal como se pode notar nos trabalhos efetuados por Bourdieu (1974), entre outros.

Mas, dentre os trabalhos desenvolvidos, pautados pelo exame do estabelecimento da crença como fundamento da fé religiosa, podemos ressaltar: Chabrol e Marin (1980); Derlorme e Geoltrain (1992); Discini (2005a); Fiorin (1988); Maingueneau (1983, 2005a); Jadon (2005); Martino (2003); Mendes (2009); Orlandi (1996); Panier (1986, 2008); RamosSilva (2007); Silva (2008); Thériault (2006); bem como os periódicos da Revista trimestral 
Semiotique et Bible, publicados sob a direção do centro para análise do discurso religioso de Lyon (CADIR).

A própria noção de discurso de divulgação religiosa, termo cunhado em trabalho que recentemente desenvolvemos (RAMOS-SILVA, 2007), requer maior aprofundamento e explicitação mediante um corpus de análise mais abrangente do que o anteriormente proposto. Para tanto, fez-se necessário, dentro do campo discursivo religioso, que procedêssemos à delimitação de três totalidades diferenciadas, as quais designamos: a) discurso fundador; b) discurso de fidelização religiosa; c) discurso de divulgação religiosa.

Concluímos nossa dissertação de mestrado, desejosos de que pudéssemos ter contribuído para a ampliação do entendimento da cena fundadora, a Bíblia Sagrada, do próprio discurso religioso e do espaço discursivo de divulgação religiosa.

Entretanto, a análise deixou aberta a possibilidade de ampliar a relação estabelecida entre os diversos gêneros discursivos pertencentes à divulgação religiosa

Partimos com o olhar analítico dos textos de divulgação religiosa, como continuidade do nosso trabalho de mestrado, em que analisamos semioticamente os diferentes mecanismos de construção do sentido dos enunciados de divulgação religiosa de duas religiões (Católica e Testemunha de Jeová).

Contudo, no que concerne à seleção do corpus da presente pesquisa, estabelecemos como critério o exame de textos de divulgação religiosa relativos à Igreja Católica (doravante IC), o que motivou o inevitável reconhecimento de diversos gêneros discursivos atrelados a essa totalidade. Orientados pelo princípio de que o sentido só de define relacionalmente, ao longo do desenvolvimento de nossa pesquisa, cotejamos o modo próprio de habitar o espaço social via divulgação religiosa. Para isso, como método, priorizamos o exame dos textos relativos à divulgação promovida pela Igreja Católica (IC), textos aproximados com outros, que abordassem temáticas semelhantes, também voltados para a divulgação religiosa, em especial aqueles representativos da Igreja Universal do Reino de Deus (IURD) e da Igreja das Testemunhas de Jeová (TJ). Desse modo, procuramos entender o estatuto identitário, a voz social, o corpo sensível da IC apreensível nos textos de divulgação religiosa, em contraste com textos de outras instituições.

Diferentes apreensões do sujeito farão emergir diferentes modos de presença, oriundos de uma mesma totalidade discursiva de divulgação, para os quais delimitamos a configuração de um modo mais arrebatado ou menos arrebatado de presença. 
Portanto, a pesquisa, em relação à utilização de diversos gêneros do campo discursivo religioso (artigo jornalístico de divulgação religiosa, entrevista, semanário litúrgicocatequéticos, roteiro preparatório à confissão, encíclica, catecismo, tratado, oração etc), poderia delinear, de forma mais abrangente, a tipologia dos discursos de fundação, fidelização e divulgação religiosa que buscamos propor neste estudo.

Destacamos que optamos por recortar dos textos passagens essencialmente representativas, que pudéssemos analisar com vistas à exaustividade. Esse procedimento justifica outro: os textos na íntegra constam de um anexo e compõem o segundo volume da tese.

Mediante essas considerações, esperamos poder contribuir com o estudo dos discursos de divulgação religiosa, com o exame da própria esfera de circulação do sentido religioso, ou seja, com reflexões a respeito do discurso religioso, como enunciado, enunciação, éthos, estilo e aspecto (ritmo).

Elencamos, abaixo, os objetivos principais segundo os quais esta tese se desenvolve:

a) desenvolver a noção semiótica de estilo, visando a propostas de operacionalização para a noção de éthos, conforme subsídios encontrados tanto numa estilística discursiva, como no referido "ponto de vista tensivo sobre o sentido";

b) dar prosseguimento aos trabalhos de Discini (2004a, 2005c, 2010), ao realizar a homologação da noção de estilo, éthos, com a operacionalização da noção do sujeito como aspecto. Propomos, dessa forma, respaldados pelos desenvolvimentos de Discini (Idem), promover a articulação da noção de estilo à aspectualização do ator da enunciação;

c) delinearemos, portanto, como se constitui "o aspecto do ator da enunciação como efeito de individualidade dado por uma tendência contínua e predominante, quer à aceleração, quer à desaceleração perceptiva" (DISCINI, 2004a, p. 1);

d) associar as noções de éthos ao conceito de presença, noção concernente à semiótica tensiva, e, nesse sentido, com apoio na noção de ritmo, assinalar a noção do observador que, ao imprimir um ritmo aos seus discursos, contribui para a fundamentação do éthos; 
e) organizar uma tipologia dos discursos de divulgação religiosa calcada no enunciatário e determinar como os textos que materializam a divulgação religiosa alcançam certa especificidade rítmica para que se defina a cena enunciativa;

f) dessa maneira, mediante as noções teóricas esboçadas, estabeleceremos, com mais profundidade, as diretrizes dos mecanismos de construção do sentido que constroem os enunciados enfeixados pelo discurso de divulgação religiosa;

g) procurar instituir as particularidades que distinguem o discurso religioso, o discurso fundador, o discurso de fidelização e o discurso de divulgação religiosa, a partir das análises dos enunciados;

h) observar as recorrências dos mecanismos de construção do sentido dos enunciados reunidos por ambos os discursos;

i) depreender como a própria escolha dos recursos gramaticais reflete, por meio da entonação expressiva empregada, o tom do sujeito divulgador.

\section{Estrutura da tese}

A tese está organizada estruturalmente em três conjuntos discursivos: a) discurso fundador; b) discurso de fidelização religiosa; c) discurso de divulgação religiosa. Permeando todo esse fazer relativo à divulgação religiosa (Capítulo I), que supõe uma articulação com o modo próprio de ser do sujeito depreensível de tais textos, está o discurso fundador, do qual analisamos semioticamente excertos extraídos da Bíblia Sagrada. Dos conceitos advindos da Análise do Discurso francesa, destacamos as noções de "discurso fundador" (ORLANDI, 2003), "dêixis fundadora" (MAINGUENEAU, 1997), "cena validada" (Idem, 2005) e "hiperenunciador" (Idem, 2008). Buscamos compreender os mecanismos de construção do sentido que tornam possível o entendimento da cena fundadora, tida como verdade revelada discursivamente, a Bíblia Sagrada. Propomos analisar, com o auxílio de um instrumento 
teórico-metodológico, o percurso gerativo do sentido, excertos extraídos do Antigo e do Novo Testamento do discurso fundador bíblico. Do Antigo Testamento, recortamos a narrativa bíblica de Caim e Abel (Gn 4, 1-16), que se constitui como discurso fundador do enunciado da encíclica "Evangelium Vitae", apresentada como o relato inaugural da violência contra a vida. A encíclica será objeto de análise do terceiro Capítulo desta tese. No que concerne ao Novo Testamento, tomamos a narrativa bíblica dos Atos dos Apóstolos (At, 1-3), considerada o primeiro relato de divulgação dos ideais cristãos da Igreja Primitiva. Tencionamos demonstrar como o próprio entendimento da cena fundadora bíblica tornará possível depreender o éthos tido como modo de ser e de habitar o espaço social desse discurso.

Para a análise dos enunciados de fidelização religiosa (Capítulo II), teremos como base os preceitos da semiótica greimasiana, sobretudo no que diz respeito ao exame da dimensão passional do discurso (GREIMAS, 1993), seus recentes desenvolvimentos tensivos (ZILBERBERG, 2006a) e da noção de "práticas semióticas" (FONTANILLE, 2008). Destacamos também alguns conceitos advindos da Análise do Discurso Francesa: as noções de participação (MAINGUENEAU, 2008) e de fórmula discursiva (KRIEG-PLANQUE, 2010).

Dentro da perspectiva de estudo da crença no âmbito semiótico, além das noções de divulgação religiosa e de discurso fundador, procuramos analisar ainda textos que julgamos por bem nomeá-los como pertencentes à experiência da palavra e dos quais nos ocupamos no segundo Capítulo. Para esses textos, temos: oração, ladainha, roteiro de preparação para confissão, novena, folheto de missa (suporte do rito eucarístico), este último também denominado semanário litúrgico catequético. Sob essa "rubrica", reunimos gêneros que não contradizem a orientação enunciativa de divulgação religiosa, mas que, ao mesmo tempo, não se restringem a tal divulgação. São gêneros representativos da prática religiosa católica, voltada para arrebanhar mais e mais fiéis no exercício da própria fidelização. O folheto de missa, por exemplo, com propriedade designado como semanário litúrgico-catequético, é um desses gêneros de fronteira entre a divulgação e a fidelização religiosa. Tais gêneros foram reunidos neste trabalho, porque se emparelham àqueles de divulgação, para que se possa depreender o éthos católico, tal como um sujeito com caráter próprio.

Ressaltamos como objetivo específico do terceiro Capítulo desta tese entender o éthos do enunciador da divulgação religiosa como efeito de sentido de uma totalidade enunciada (Capítulo III). Deliberamos partir de uma totalidade, a divulgação religiosa. Dentro da 
perspectiva de exame dos enunciados que compõem a totalidade de divulgação, reconhecemos e isolamos metodologicamente diferentes níveis hierárquicos em que a divulgação se realiza. Procuramos, assim, formular uma tipologia do discurso de divulgação religiosa, tendo, como base, o estabelecimento de cinco cenas enunciativas diferenciadas: a) divulgação religiosa especializada; b) divulgação religiosa instrucional; c) divulgação para conscientização social; d) divulgação religiosa propagandista; e) divulgação religiosa midiática.

Procedemos, diante disso, à análise dos enunciados de divulgação que compõem cada uma das cinco cenas consideradas, mediante a utilização do percurso gerativo do sentido como ferramenta necessária para depreendemos as marcas da enunciação deixadas pelo enunciado. Como o todo está nas partes, buscamos, nesse sentido, por meio da análise dos enunciados de divulgação, estabelecer recorrências que compõe a materialidade discursiva da totalidade, a enunciação de divulgação enquanto éthos. Portanto, permeando o fazer relativo à divulgação religiosa, que supõe uma articulação com o modo próprio de ser do sujeito depreensível de tais textos, nossa intenção é pensar a tipologia dos discursos de divulgação religiosa proposta, relacionando-a aos diferentes modos segundo os quais se processualiza o paradigma da crença. Propomos, dessa forma, delinear de maneira mais abrangente o modo de presença dos enunciados enfeixados pelo discurso de divulgação religiosa e, por conseguinte, o modo próprio de presença da totalidade recortada e, até mesmo, do próprio discurso religioso.

Reservamos, para o Capítulo IV, o espaço necessário para os tópicos que pretendemos elencar, seja como base para a operacionalização da noção de éthos, seja como base para a depreensão de modos de construção dos próprios gêneros cotejados. 
Cap. I

O DISCURSO FUNDADOR NA ESFERA RELIGIOSA

As Sagradas Escrituras são um livro cheio de cacos. [...] Ao ler as Escrituras comportamo-nos como um artista que seleciona cacos para construir um mosaico ou como um compositor a compor a sua sonata.

Rubem Alves ${ }^{3}$

${ }^{3}$ Alves (2007, p.16). 


\section{A Sagrada Escritura como objeto de análise}

O sentido não está por detrás do texto: ele é o sistema de regras que permite gerar o jogo diferencial das oposições, que ordena minha leitura ao longo de um texto "infinito", do qual o texto que leio nada mais é do que uma atualização limitada acidentalmente, isto é, historicamente limitada.

C. Chabrol $^{4}$

Desvendar o processo de significação do discurso bíblico, um dos textos fundadores de nossa cultura, e que até hoje molda a mente dos cristãos, revestido por uma aura mítica de sacralidade e intocabilidade, tem o status de uma empreitada, no mínimo, desafiadora.

A própria definição do que seja o discurso bíblico apresenta uma enorme dificuldade para o analista. Para os cristãos, membros de uma fé comum, essa questão não se coloca, pois, para eles, a Bíblia é o livro da vida da comunidade de Jesus. Entendemos por "comunidade de Jesus" a comunidade de Israel na qual nasceu Jesus, aquela que surge a partir dele e, por conseguinte, a comunidade dos fiéis da contemporaneidade que pretendem manter-se fiéis ao modo de vida e aos ensinamentos deixados por Jesus. O sentido da Escritura seria, portanto, a história e a realização salvífica na pessoa de Cristo.

Como muitos outros considerados fundadores de diversas religiões ou religiosidades, Jesus nada deixou documentado a respeito de seu pensamento e doutrina. Tudo de que dispomos se encontra presente nos Evangelhos. De acordo com sua etimologia, a palavra Evangelho, originária do grego evangélion, besoura em hebraico, teria como significado "Boa Nova". Essa expressão era utilizada originalmente nos textos primitivos para designar os ensinamentos da doutrina cristã, e, posteriormente, passa a ser empregada como designação dos livros ou documentos que contêm a história das origens do cristianismo.

A Bíblia, advinda do termo grego ta bíblia 'os livros', constitui-se como a coleção de livros considerados como escritos sob inspiração do Espírito Santo, livros em que judeus e cristãos reconhecem a palavra de Deus. A própria designação ta bíblia exprime a origem e a autoridade de tais escritos considerados "os livros por excelência”. A Bíblia é composta de 73 escritos e divide-se em duas partes, denominadas Antigo e Novo Testamento. O cânone das Escrituras na tradição católica constitui-se de 46 livros pertencentes ao Antigo Testamento e

\footnotetext{
${ }^{4}$ Chabrol (1980, p.4)
} 
de 27, ao Novo Testamento. Na versão protestante, a Bíblia apresenta 66 livros, divididos em 39 para o Antigo Testamento e 27, para o Novo.

O discurso bíblico dispõe de uma diversidade de gêneros, dentre os quais podemos destacar: a) fragmentos de epopéia; b) narrações históricas; c) listas genealógicas; d) narrações episódicas ou romanceadas; e) oráculos proféticos; f) sermões; g) textos legislativos; h) poemas; i) orações; j) ensaios filosóficos; k) cantos de amor; 1) cartas.

Todo o Cristianismo baseia-se nos escritos bíblicos tidos como autoridade suprema por expressarem a "Palavra de Deus".

A Sagrada escritura se institui para a comunidade de fé enquanto uma cena fundadora, um discurso divinamente inspirado, assim como a interpretação que dela se realiza.

\footnotetext{
As coisas divinamente reveladas, que se encerram por escrito e se manifestam na Sagrada Escritura, foram consignadas sob a inspiração do Espírito Santo. [...] Portanto, já tudo o que os autores inspirados ou os hagiógrafos afirmam deve ser tido como afirmado pelo Espírito Santo, devese professar que os livros da Escritura ensinam com certeza, fielmente e sem erro a verdade que Deus em vista da nossa salvação quis fosse consignada nas Sagradas Escrituras (PAULO VI, 2007, p. XV).
}

A redação dos livros sagrados é entendida, por essa comunidade de fé, como uma escolha proveniente de Deus. Este teria procedido à seleção de alguns homens para que escrevessem, na condição de autores verdadeiros, aquilo mesmo que estivesse dentro dos desígnios divinos.

Desse modo, poder-se-ia, inicialmente, definir a Bíblia como o conjunto de todos os livros do Antigo e do Novo Testamento, considerados como sagrados e canônicos, segundo a fé apostólica, pois escritos sob inspiração do Espírito Santo.

Entretanto, a questão da Escritura como divinamente inspirada não faz parte da preocupação da prática de estudos semióticos. Para o analista, o texto bíblico possui o mesmo estatuto de qualquer outro texto que se oferece como objeto de análise.

\section{O Discurso fundador bíblico}

A noção de discurso fundador pode ser entendida como um discurso que "funciona como referência básica no imaginário constitutivo" (ORLANDI, 2003, p. 13). 
$\mathrm{O}$ que o caracteriza como fundador - em qualquer caso, mas precipuamente nesse - é que ele cria uma nova tradição, ele re-significa o que veio antes e institui aí uma memória outra. É um momento de significação importante, diferenciado. [...] [Ele institui um outro lugar de sentido] estabelecendo uma outra região para o repetível (a memória do dizer), aquela que a partir de então vai organizar outros e outros sentidos [...]. É a isto que chamamos discurso fundador (ORLANDI, 2003, p. 13-15).

Para a perspectiva da $\mathrm{AD}$, aqui também herdada pela Semiótica, temos a noção de "dêixis fundadora", passível de homologação ao discurso fundador. A dêixis fundadora "deve ser entendida como a(s) situação(ões) de enunciação anterior(es) que a dêixis atual utiliza para a repetição e da qual retira boa parte de sua legitimidade" (MAINGUENEAU, 1997, p. 42).

Pensar a Bíblia enquanto expressão autoritária (palavra revelada e divinamente inspirada) e orientada para a sua práxis (norma para uma comunidade de fé) pressupõe o devido entendimento por essa comunidade do sentido do texto herdado pela tradição e que lhe conferiu o caráter sagrado. Ressaltamos que esse "sentido" será analisado como "efeito de sentido" presente no enunciado bíblico e estará indissoluvelmente ligado à práxis da comunidade. Isso, pois, "fora da comunidade e sua práxis que interpreta o texto, não se pode garantir que o texto suscite o sentido em razão do qual ele foi conservado e transmitido" (COHN e NASCIMENTO, 2009, p. 113).

Essa relação do discurso bíblico como discurso vinculado à práxis de uma determinada comunidade de fé remete ao conceito de memória, conjunto de saberes e de crenças partilhados pela tradição de uma determinada comunidade discursiva.

Associamos o conceito de memória à noção de configuração discursiva, tal como apresentado pela teoria semiótica.

\footnotetext{
As configurações discursivas aparecem como espécies de micronarrativas que têm uma organização sintático-semântica autônoma e são suscetíveis de se integrarem em unidades discursivas mais amplas, adquirindo então significações funcionais correspondentes ao dispositivo de conjunto. [...] Quer isso dizer que uma configuração não é dependente de seu contexto, mas pode ser dele extraída e manifestada sob a forma de um discurso autosuficiente (GREIMAS; COURTÉS, 2008, p. 87-88).
}

A análise da configuração discursiva torna possível que se reconheça nela "todos os níveis e todos os componentes de um discurso examinado através das diferentes instâncias de seu percurso gerativo" (Idem, p. 89). Essa organização subjacente, dada pelo discurso 
fundador bíblico, é o que permeará a análise dos enunciados de fidelização e de divulgação religiosa, objetos de análise dos capítulos subsequentes.

Tendo essas concepções em mente, retomemos, então, a definição das características do discurso fundador bíblico. Para isso, reiteramos inicialmente uma questão frequentemente trazida à tona pelos pesquisadores de religião ou de religiosidades. Como caracterizar o discurso fundador bíblico: mito, história ou literatura? Para o desenvolvimento deste trabalho, lembramos a perspectiva da religião entendida na acepção de mito ${ }^{5}$.

Tomemos as proposições de Eliade (2004, p. 11) concernentes à conceituação de mito. Segundo o autor, os mitos se caracterizam, primordialmente, pelo seu caráter veridictório, “o mito fala apenas do que realmente ocorreu, do que se manifestou plenamente, por oposição às fábulas e contos, que não precisam apresentar necessariamente esse caráter de veridicção".

Conforme Eliade (1993), o mito possui como função fundamental fornecer e fixar modelos e justificativas de todos os ritos e ações humanas significativas.

Qualquer que seja a sua natureza, o mito é sempre um precedente e um exemplo, não só em relação às ações - "sagradas" ou "profanas" - do homem, mas também em relação à sua própria condição. Ou melhor: um precedente para os modos do real em geral. "Nós devemos fazer o que os deuses fizeram no princípio". "Assim fizeram os deuses, assim fazem os homens" (ELIADE, 1993, p. 339).

A verdade proposta pelo mito é uma verdade simbólica: "ela propõe para o mundo, para a vida e para as relações humanas, um sentido que não se pode impor nem demonstrar; ou embarcamos nele ou não, ou o poder do fascínio do mito exercerá seu efeito, ou não nos atingirá!" (DABEZIES, 1997, p. 734).

Entretanto, se consideramos o discurso fundador como o que está comprometido com valores ideológicos éticos e morais, em conformidade com a formação ideológica na qual ele se acha instaurado, nossa leitura afasta a Bíblia do puro mito.

Observamos que a ação simbólica mobilizada pela religião consiste mais em incutir valores ideológicos, éticos e morais e menos em circunscrever seu dizer ao mito: assim se dá o discurso fundador no campo religioso.

\footnotetext{
5 "O mito é uma explicação das origens do homem, do mundo; da linguagem; explica o sentido da vida, a morte, a dor, a condição humana. Vive porque responde à angústia do desconhecido, do inexplicável; dá sentido àquilo que não tem sentido" (FIORIN, 2002, p. 10).
} 
Segundo Mendes (2009, p.45), a especificidade do mito, no que tange ao nível discursivo do percurso gerativo do sentido, estaria presente nos processos de actorialização (os atores se situam num plano infra ou supra-humano), temporalização (o tempo é sempre uma referência interna) e espacialização (o espaço do mito estaria ancorado em lugares definidos dentro de sua respectiva cultura).

Ao tomarmos o nível das estruturas semionarrativas no discurso fundador, verificaremos que este apresenta, em seus diversos gêneros, a figura de um destinador (hiperenunciador divino) que manipula e sanciona a competência dos sujeitos responsáveis pela performance das ações de religamento do homem (fiel) a Deus, por intermédio do agente religioso (padre, por exemplo). Assim sendo, o objetivo fundamental dessa narrativa é se posicionar como justificativa de uma prática social em uma determinada cultura. Notamos o enfraquecimento do impacto do mito, à medida que ascende o poder institucional. Como no discurso fundador o agente religioso está apagado, temos, contrariamente, a ascensão do poder do mito (acento mítico) e o arrefecimento da força institucional.

De acordo com Chauí (2006, p. 70), o tempo bíblico, de modo diferente do tempo cósmico (natural) e épico (histórico), “é dramático, pois a história sagrada é não somente sagrada, mas também, o drama do afastamento do homem de Deus e da promessa de reconciliação de Deus com o homem". O termo "testamento" que caracteriza a composição bíblica substitui o antigo termo grego que significava pacto ou aliança. O relato bíblico é a aliança feita por Deus com os homens por intermédio de Moisés (Antigo Testamento) e, posteriormente, pelo ministério de Jesus Cristo (Novo Testamento). De fato, a cristologia nasce em dois movimentos sucessivos: no primeiro movimento, o Antigo Testamento é interpretado como profecia do advento do Messias; no movimento seguinte (quando, historicamente, o mundo não acabou depois da Ressurreição de Cristo e o Juízo Final tarda a acontecer enquanto o mal se espalha por toda a parte), o Novo Testamento passou a ser interpretado como profecia do Segundo Advento, a Segunda Vinda do Messias no fim dos tempos, com o que, finalmente, a história estaria completamente consumada (CHAUÍ, 2006, p. 72).

Dessa forma, o tempo bíblico não exprime a circularidade dos ciclos da natureza, nem tampouco a narração de feitos humanos, mas configura-se como um tempo sagrado, caracterizado como o drama do reencontro do homem com Deus. Portanto, podemos conceber a história cristã como uma operação de Deus no tempo. Falamos de um tempo semantizado de 
modo próprio. Para esclarecer, lembramos que a não temporalização e a não espacialização dizem respeito a efeitos de sentido dados no texto e pelo texto.

Tomemos a narrativa bíblica do nascimento miraculoso de Jesus ${ }^{6}$ :

Ora, a origem de Jesus Cristo foi assim:

Maria, sua mãe, estava prometida em casamento a José e, antes de passarem a conviver, ela encontrou-se grávida pela ação do Espírito Santo. José, seu esposo, sendo justo e não querendo denunciá-la publicamente, pensou em despedi-la secretamente. Mas, no que lhe veio esse pensamento, apareceu-lhe em sonho um anjo do Senhor, que lhe disse: "José filho de Davi, não tenhas receio de receber Maria, tua esposa; o que nela foi gerado vem do Espírito Santo. Ela dará a luz a um filho, e tu lhe porás o nome de Jesus, pois ele vai salvar o seu povo dos seus pecados". Tudo isso aconteceu para se cumprir o que o Senhor tinha dito ao profeta: "Eis que a virgem ficará grávida e dará a luz a um filho. Ele será chamado pelo nome de Emanuel, que significa: Deus conosco" (Mt 1, 18-23, BÍBLIA SAGRADA, CNBB, 2007, p. 1202).

O nascimento de Cristo é tido por esse discurso como uma obra divina que ultrapassa toda compreensão e possibilidade humanas. Ainda que não se admita que uma virgem possa dar a luz a um filho, isso é possível no âmbito contratual da fé como obra do Espírito Santo. Embora a modalidade concessiva (ZILBERBERG, 2004), situada no âmbito do acontecimento, tenha o poder de instaurar um programa dado como irrealizável em outras dimensões, o resíduo mítico impede que se instaure a lógica concessiva na Bíblia. O nascimento miraculoso de Jesus é tido como verdade indiscutível, é palavra revelada, e, portanto, pertencente à doxa, à lógica implicativa do âmbito contratual da fé.

Conforme Bauer (1988), o milagre, ao constituir-se como algo inexplicável, é atribuído à figura de um enunciador divino que nele revela, sobretudo, o seu poder, mediante a exposição de suas ações na narrativa.

Os motivos miraculosos consistem, portanto, em narrativas de caráter simbólico cujo objetivo central reside na crença inquestionável e posterior adesão do sujeito (enunciatário) ao âmbito contratual da fé proposto pelo enunciado.

Como exemplos dessas narrativas, temos: a multiplicação dos pães $(\mathrm{Jo}, 6,1)^{7}$, a cura de um cego $(\text { Jo, } 9,1-7)^{8}$, entre outras.

\footnotetext{
6 "Desde as primeiras formulações da fé, a Igreja confessa que Jesus foi concebido exclusivamente pelo poder do Espírito Santo no seio da Virgem Maria, afirmando também o caráter corporal deste evento: Jesus foi concebido do Espírito Santo, sem sêmem" (PAULO II, 2001, p. 140).

7 “Levantando os olhos e vendo uma grande multidão que vinha até ele, Jesus disse a Felipe: 'Onde vamos comprar pão para que estes possam comer?' Disse isso para testar Felipe, pois ele sabia muito bem o que ia fazer. Felipe respondeu: 'Nem duzentos dinários de pão bastariam para dar um pouquinho a cada um'. Um dos discípulos, André, irmão de Simão Pedro, disse: 'Está aqui um menino com cinco pães de cevada e dois peixes.
} 
A narrativa dos milagres reflete, por conseguinte, dado o seu caráter figurativo, uma estreita relação do indivíduo com a comunidade. Ao receberem uma significação central, o discurso argumentativo por ela pressuposto visa, de acordo com Fontanille (2008, p. 42), a uma fase que lhe é posterior: a crença, a adesão e, por fim, a decisão.

À presença do sagrado, transformado pelo acontecimento miraculoso e realizado mediante a intervenção divina, segue-se o reconhecimento por parte do enunciatário; a adesão a esse discurso e, finalmente, à decisão de integrar-se a comunidade de fé que tem a narrativa bíblica como cena fundadora. Ressaltamos, ainda, o caráter elocutório e perlocutório da enunciação do texto bíblico, pois o ato de discurso também se realiza no enunciado como uma ação. A própria significação religiosa da comunidade pressupõe o contrato fiduciário que tem como condição prévia a crença e a confiança no poder-fazer de Cristo.

Concordamos com a afirmação de Mendes (2009, p. 49) segundo a qual o discurso bíblico pode ser definido como "um discurso em eterna enunciação". Isso, porque, tal como ressalta a autora, "há dois mil anos ele vem sendo falado, escrito, compilado, editado, lido e ouvido nos lares e nas igrejas em determinados pontos do mundo". Entretanto, antes de tratarmos da transmissão do discurso fundador, presente na vida da Igreja e de uma comunidade de fé, por intermédio das práticas de fidelização religiosa, e que serão objeto de análise do segundo Capítulo desta tese, cabe-nos destacar o aspecto incoativo do enunciado bíblico em $\mathrm{si}^{9}$.

Temos de levar em conta a passagem do enunciado bíblico enquanto cena validada, enunciado destacado, apresentado como modelo ou antimodelo de uma cena de discurso, à sua transmissão, seja pelas práticas de fidelização, seja pelos enunciados de divulgação ${ }^{10}$.

\footnotetext{
Mas, que é isso para tanta gente?' Jesus disse: 'Fazei as pessoas sentar-te'. Naquele lugar havia muita relva, e lá se sentaram os homens em número de aproximadamente cinco mil. Jesus tomou os pães, deu graças e distribuiu aos que estavam sentados, tanto quanto queriam" (Jo, 6-1-11, BÍBLIA SAGRADA, CNBB, 2007, p. 1318).

8 "Jesus vinha passando, quando viu um cego de nascença. Os seus discípulos lhe perguntaram: 'Rabi, quem pecou para que ele nascesse cego, ele ou seus pais?' Jesus respondeu: 'Nem ele, nem seus pais pecaram, mas é uma ocasião que se manifestem nele as obras de Deus. É preciso que façamos as obras daquele que me enviou, enquanto é dia. Vem a noite, quando ninguém poderá trabalhar. Enquanto estou no mundo, sou a luz do mundo'. Dito isso, cuspiu no chão, fez barro com a saliva e aplicou-a nos olhos do cego. Disse-lhe então: 'Vai lavar-te na piscina de Siloé' (que quer dizer: Enviado). O cego foi, lavou-se e continuou enxergando" (Jo, 9,1-7, BÍBLIA SAGRADA, CNBB, 2007, p. 1323)".

${ }^{9}$ A concepção linguística de aspecto se refere aos diferentes graus de desenvolvimento, de realização de um processo, bem como à maneira de conceber-se o processo em si. Por aspecto incoativo entendemos o início de um novo estado, de uma ação ou de um processo (TRAVAGLIA, 2006).

10 "A cena validada é ao mesmo tempo exterior e interior ao discurso que a evoca. É exterior no sentido que lhe preexiste, em algum lugar do interdiscurso; mas é igualmente interior, uma vez que é também o produto do discurso, que a configura segundo seu universo próprio" (MAINGUENEAU, 2005. p. 82).
} 
A cena validada corresponde ao estoque de cenas disponíveis e que pode variar de acordo com os discursos (MAINGUENEAU, 2005, p. 81).

De acordo com Maingueneau (2008b, p. 95), a participação pressupõe a existência da figura de um hiperenunciador, "cuja autoridade garante menos a verdade do enunciado - no sentido estrito de uma adequação a um estado de coisas do mundo -, e mais amplamente sua 'validade', sua adequação aos valores, aos fundamentos de uma coletividade”. No caso das religiões escritas, tal como é o caso do cristianismo, o Thesaurus que torna possível a participação coincide com um único livro, a Bíblia, cujo hiperenunciador é o próprio Deus. Maingueneau (Idem) ressalta ainda que, embora a maior parte da Bíblia não seja constituída de falas que emanem diretamente de Deus, mas de autores anônimos ou míticos, para os “membros da comunidade, os múltiplos 'autores' da Escritura são apenas porta-vozes do único e verdadeiro Autor (o Espírito de Deus) que os inspira e garante o conteúdo dos textos, indiferente à diversidade dos gêneros e das épocas" (Idem, p. 102).

Podemos afirmar que há, no relato bíblico, "um discurso não-temporalizado e nãoespacializado, que se temporaliza e se espacializa no comentário ${ }^{11 "}$ (FIORIN, 1988, p. 142). Temos, assim, uma aspectualidade incoativa no discurso fundador, cena validada e enunciado destacado, que se realiza mediante a celebração periódica das prescrições rituais referentes às práticas de fidelização de uma comunidade de fé (aspectualidade durativa ${ }^{12}$ ) e que se temporaliza e se espacializa no comentário (discurso de divulgação religiosa).

O esquematismo tensivo (ZILBERBERG, 2004) consiste na mistura de duas ordens ou dimensões, uma dimensão da intensidade (do sensível) e uma dimensão da extensidade (do inteligível). Cada uma dessas dimensões é analisável em valências que segmentam um intervalo de referência, ao que associamos uma sintaxe específica. Para a dimensão da intensidade, o intervalo de referência [impactante vs. fraco] refere-se a uma sintaxe

\footnotetext{
11 "O texto comentado não é fonte nem matriz dos discursos que a ele se referem. O comentário não designa o significado do texto comentado, mas produz significantes para oferecer ao texto um novo contexto, que permite efetuar dois tipos de recategorização. De um lado, enunciados narrativos deslocam-se ao longo do esquema narrativo. De outro, as figuras do texto comentado podem encontrar-se em configurações discursivas, no seio das quais o comentário seleciona outros percursos e outros valores. Por exemplo, pode-se entender a morte de Cristo como sanção ou atribuição de competência; a paixão pode ser lida no percurso da morte ou do assassinato. Essa recategorização permite variar a leitura do texto comentado. Em síntese, o discurso religioso militante designa explicitamente o seu outro, tendo uma função citativa bem clara, e tira dele sua autoridade, ao mesmo tempo que torna seus significantes disponíveis para outro uso" (FIORIN, 1988, p. 142).

${ }^{12}$ Por aspectualidade durativa, temos a introdução da progressividade a uma situação anteriormente pontual.
} 
ascendente ou decadente. Para a dimensão da extensidade, o intervalo de referência [concentrado vs. difuso] opera a sintaxe da extensidade mediante triagens e misturas.

Tomemos a sintaxe da extensidade, ao verificar "a divisão das grandezas em classes enumeráveis e a instabilidade dessa divisão" (Idem, p. 73).

Estabelecemos, assim, mediante a recursividade das operações de triagem e de mistura, a concepção do tratamento analítico do afeto por meio da instituição dos estados aspectuais "caracterizados pelas tensões e ambivalências que os modos de existência peculiares à sintaxe discursiva determinam" (Idem, p. 76).

Temos, no discurso fundador, a prevalência das operações de triagem. O predomínio da homogeneidade ${ }^{13}$, da dissociação e do acento mítico, nesse discurso, confirma a presença dos valores de absoluto, voltados para a exclusividade e unicidade (Idem, p.90).

Procuraremos analisar, nos capítulos subsequentes, como são evocadas as cenas validadas (discurso fundador) que situam os enunciados de fidelização e de divulgação religiosa e que tornam possível a depreensão do éthos católico enquanto um sujeito com caráter próprio.

\section{Algumas questões referentes à tradução bíblica}

Algumas considerações se fazem necessárias no que diz respeito à questão da tradução bíblica. Não se possui manuscrito autógrafo algum dos textos bíblicos. As cópias antigas, em manuscritos, únicas das quais se dispõem, apresentam algumas variações. Ressaltam Conh e Nascimento (2009, p. 109) que, diante disso, “o tradutor moderno, normalmente, segue uma 'edição crítica', que fez de antemão a seleção de formas textuais que tem maior probabilidade de serem originais". A tradução deve "transportar", trans-ducere, o texto a fim de que o enunciatário compreenda o seu sentido, com a maior probabilidade de originalidade.

Uma boa tradução bíblica não pode escapar da incumbência de "transmitir" a mensagem em forma verificável. Daí a necessidade de manter minimamente a forma do texto original. Quanto mais a interpretação no afã interpretativo, se afasta do texto original, mais necessita de notas explicativas (COHN; NASCIMENTO, 2009, p. 117).

\footnotetext{
${ }^{13}$ Importante ressaltar uma importante consideração a respeito da retificação que realizamos em relação ao termo "heterogeneidade", indicado incorretamente como "heterogeneidade" (sic) no texto original (Zilberberg, 2004).
} 
"A Bíblia é o livro da comunidade e só se abre para quem tem a devida iniciação na comunidade" (Idem, p.118). Destacamos o caráter "circunscritivo" dessa afirmação. A comunicação intrapares se insere no domínio da triagem. O "devido entendimento" do enunciado bíblico colocar-se-ia como acessível apenas aos membros de uma determinada comunidade de fé. Ressalvamos, mais uma vez, que esse "devido entendimento" será considerado como efeito de sentido a ser depreendido dentro de uma formação discursiva determinada.

A Bíblia é entendida enquanto um conjunto de textos normativos à práxis de uma determinada comunidade de fé, que tem por objetivo uma utilização litúrgica, ou paralitúrgica.

A assembléia é o lugar por excelência da proclamação da Palavra. "Na Assembléia, a palavra de Deus deve ser levada à atualidade, confrontada com a vida dos fiéis, interpretada para a vida de hoje" (Idem, p. 120). Tal é o papel apresentado pela homilia, dentro do ritual eucarístico da Santa Missa.

Assim sendo, qual seria a finalidade da tradução? De acordo com os autores, "a arte do tradutor consistirá em 'criar o espaço linguístico adequado' para o diálogo entre os ouvintes da Palavra de hoje e o texto original em sua alteridade" (Idem, p. 121).

No que concerne ao panorama de tradução bíblica no campo católico, observamos que não há unanimidade quanto à tradução da Bíblia. Cabe evidenciar que a própria escolha da tradução reflete o enunciatário visado por tal discurso. Não temos uma tradução revestida de autoritarismo, tida como uma versão única, comum a toda comunidade de fé. Dentre as traduções existentes, citamos: a) as bíblias de estudo, das quais destacamos a Bíblia de Jerusalém, a Bíblia do Peregrino e a tradução da Bíblia Sagrada da CNBB, embora esta última apresente as introduções e notas de forma mais condensada; b) bíblias pastorais, em estilo e linguagem próximos ao cotidiano e com poucos detalhes para o estudo do texto, tais como a Bíblia Sagrada (Ed. Ave Maria) e a Bíblia Mensagem de Deus (Ed. Loyola), entre outras.

No que diz respeito à versão bíblica na qual baseamos nosso trabalho, utilizamos a tradução da Bíblia Sagrada da CNBB, texto de referência para os documentos oficiais da Conferência Nacional dos Bispos do Brasil. 


\section{A Análise semiótica como princípio de método para uma exegese}

A interpretação da Sagrada Escritura é de fundamental importância para a fé cristã e para a vida da Igreja (PONTIFÍCIA COMISSÃO BÍBLICA, 2009, p. 6). As Sagradas Escrituras, dentro da formação ideológica católica, são consideradas como um meio estável de comunicação e de comunhão entre Deus e os fiéis.

A Igreja, efetivamente, não considera a Bíblia simplesmente como um conjunto de documentos históricos concernentes às suas origens, acolhe-a como palavra de Deus que se dirige a ela e ao mundo inteiro no tempo presente (PONTIFÍCIA COMISSÃO BÍBLICA, 2009, p. 139).

A questão da interpretação e da transmissão do discurso bíblico torna-se indissoluvelmente ligada à figura do exegeta. Por exegese pode-se entender o comentário, aplicado essencialmente em relação ao texto bíblico, que tem por finalidade apresentar uma interpretação minuciosa do texto tendo por objetivo definir o seu sentido exato. Seria tarefa do exegeta alcançar o sentido autêntico do texto sagrado para, em seguida, comunicar esse sentido ao destinatário da Sagrada Escritura que é, se possível, toda a pessoa humana (PONTIFÍCIA COMISSÃO BÍBLICA, 2009, p.21).

Tomemos o documento intitulado "A interpretação da Bíblia na Igreja”, de autoria da Pontifícia Comissão Bíblica, na medida em que ele procura fornecer uma visão geral do panorama dos métodos contemporâneos em exegese. Para isso, o documento visa fazer uma breve descrição dos diversos métodos de exegese empregados, indicando suas possibilidades e seus limites. Ele busca, ainda, examinar algumas questões de hermenêutica ${ }^{14}$ e propor uma reflexão sobre as dimensões características da interpretação católica da Bíblia em relação a outras disciplinas teológicas, além de considerar, por fim, o lugar que ocupa a interpretação da Bíblia na vida da Igreja.

Dentre as perspectivas utilizadas para a interpretação, o documento destaca: a) método histórico-crítico; b) novos métodos de análise literária (análise retórica, análise narrativa e

\footnotetext{
${ }^{14}$ Para a noção de hermenêutica aludimos à definição de ciência, que tem por objeto a interpretação de textos religiosos ou filosóficos, especialmente das Sagradas Escrituras (HOUAISS, 2010).
} 
análise semiótica); d) abordagens baseadas na tradição; e) abordagem através das ciências humanas; f) abordagens contextuais; h) leitura fundamentalista.

No que se refere à exegese católica, notamos, mediante a análise do documento da Pontifícia Comissão Bíblica (2009), o uso de diversos métodos e abordagens teóricas. Neste nosso trabalho, destacamos a semiótica.

A semiótica procura distinguir-se de outras teorias do texto (histórico-crítica, pragmática, etc) "e de outras problemáticas da recepção e da interpretação que se apresentam atualmente na exegese bíblica e que intervêm na elaboração de reflexões teológicas" (PANIER, 1989, p. 19).

Amparados pelos desenvolvimentos de Chabrol (1980), Panier (1989, 2008), Delorme (1992, 1993) e Thériault (2006), procuramos caracterizar o histórico desses estudos e traçar algumas considerações a respeito de como se processa o projeto teórico da semiótica dentro da teologia bíblica.

Therialt (2006) ressalta que a emergência de uma crise da problemática histórica dentro dos estudos bíblicos abre a necessidade de uma reflexão fundamental sobre a exegese e seus métodos.

A inclusão dos estudos bíblicos no âmbito da semiótica greimasiana coincide com a publicação da obra Du Sens (GREIMAS, 1970). Thériault (2006) e Panier (2008), ao elaborarem o histórico desses estudos, expõem a importância de uma seção de três dias realizada no Grand Semináire de Versailles, em setembro de 1968, como o marco inaugural dos estudos em semiótica bíblica. Panier (1989) destaca ainda que a presença da semiótica no debate do campo de estudos exegéticos tem início na França, a partir do Congresso de 1969 da Associação Bíblica Francesa para o estudo da Bíblia (A.C.F.E.B). Os debates provenientes desse encontro foram publicados sob o título Exégèse et Hermenéutique, Paris, Seuil, Col. Parole de Dieu, 1971. Esses estudos tiveram posterior desenvolvimento em Lyon, por meio da criação, por iniciativa de J. Delorme e J. Calloud, do Centre pour l'Analise Du Discours Religieux (CADIR), com a publicação do periódico Sémiotique et Bible.

$\mathrm{O}$ interesse do exegeta por tais questões repousava principalmente na maneira de abordar o texto tal como ele se dava a ler na materialidade de seu enunciado. Enfatizamos uma mudança radical de ponto de vista por parte dos exegetas, habituados aos métodos históricos, uma "conversão radical na maneira de ler os textos e de apreender o sentido: passar 
de uma leitura diacrônica a uma leitura imanente e sincrônica"15 (THÉRIAULT, 2006, p. 68).

O exegeta, adepto da análise histórica, dispunha de um conjunto de métodos que tinham como objetivo fundamental reconstruir e resgatar a história de composição do sentido original dos textos, em verificar o sentido das palavras e o valor histórico dos acontecimentos relatados na Bíblia (Idem, p. 68).

A entrada da semiótica na exegese bíblica marca uma ruptura de isotopia ${ }^{16}$ ao incluir um horizonte epistemológico completamente diferente.

Habituados à dissecação em pequenas unidades literárias, aos extratos de composição e à pesquisa das raízes, muitos biblistas resistiram - e resistem ainda - a esta análise que se interessa pelo texto simplesmente como ele se dá a ler (Idem, 2006, p. 68).

A análise semiótica, de modo diferencial, ancora-se em dois axiomas fundamentais: o princípio da imanência e o princípio da diferença. Ela não é simplesmente um método posto ao lado de outros para a interpretação dos textos: "ela toca as questões mais fundamentais em pesquisa bíblica, as convicções primeiras da busca do sentido - se ele é originário da produção ou da geração do sentido" (Idem, 2006, p.68). A introdução da semiótica no campo de estudos bíblicos abre a estrutura da Bíblia às novas perspectivas fornecidas pelas ciências da linguagem.

O projeto semiótico aplicado aos textos bíblicos tem como objetivo fundamental esclarecer questões relativas à interpretação e assinalar algumas perspectivas para a reflexão teológica.

O conteúdo que interessa ao analista não é (ao menos numa primeira etapa), o conjunto do contexto sociológico, e sim o contexto mitológico ou, mais globalmente textual, que se apresenta [...] sob a forma de conteúdos investidos, independentes da própria narrativa e, posteriormente, sustentados pelo modelo narrativo (CHABROL, 1980, p. 6).

\footnotetext{
15 “Qualificam-se como sincrônicos os estudos que visualizam a língua, num momento dado, como um sistema estável (estudo, pesquisa, linguística sincrônicos), os fatos que são estudados como elementos de um sistema que funciona num momento dado e considerados como estáveis (fatos, dados sincrônicos)" (DUBOIS, 2001, p. 552). 16 Por isotopia, temos este esclarecimento: "Recorrência de um elemento semântico no desenvolvimento sintagmático de um enunciado, que produz um efeito de sentido de continuidade e permanência de um efeito de sentido ao longo da cadeia do discurso. Diferentemente do campo lexical [...] a isotopia não tem por horizonte a palavra, mas o discurso. Ela pode assim referir-se ao estabelecimento de um universo figurativo (isotopias de atores, tempo e espaço), mas também à tematização desse universo (isotopias temáticas, abstratas, axiológicas), e sobretudo à hierarquia entre as isotopias de leitura (por identificação de um núcleo isotopante que rege as isotopias de nível inferior" (BERTRAND, 2003, p. 421).
} 
Temos o percurso gerativo do sentido enquanto simulacro metodológico das abstrações que o leitor faz ao longo da leitura de um texto. Esse instrumento tem por objetivo permitir compreender os mecanismos de construção do sentido desse discurso fundador.

Ressaltamos os desenvolvimentos apresentados por esse quadro teórico no que concerne aos estudos bíblicos, principalmente na concepção de enunciação e dos mecanismos de instauração do leitor. O leitor é, ao mesmo tempo, sujeito do ato de interpretação e instância pressuposta. Com essa instância pressuposta, remetemos ao conceito de phátos, concebido como imagem que o enunciador tem do enunciatário e que estabelece coerções para o discurso.

Associamos a experiência eclesial da leitura do enunciado bíblico ao corpo da comunidade de fiéis, o que configura a prática de leitura na experiência de um sujeito. A leitura semiótica dos textos bíblicos se estabelece como o lugar do sujeito da enunciação no discurso. A própria palavra de Deus na Escritura é dada segundo uma dupla perspectiva: a) revelação como comunicação (mensagem); b) manifestação de um sentido para o homem.

A multiplicidade de traduções, citações e comentários concernentes à tradição de leitura da Bíblia fornece amplo material ao questionamento semiótico e coloca como central a questão da enunciação divina presente na Escritura. A própria escritura bíblica teria a função de transmitir a mensagem de Deus, "Palavra de Deus", na "palavra" (Escritura), configurando uma mediação dada mediante o narrador instaurado no texto.

A experiência da leitura do enunciado bíblico reflete por parte do sujeito "um saber sobre o desejo que instaura uma relação particular de interlocução em que se faz sua leitura" (CHABROL, 1980, p. 3).

De acordo com Chabrol (Idem, p. 3), a relação actancial destinador-destinatário, na experiência de leitura do enunciado fundador bíblico, além de privilegiar a transmissão de um objeto de comunicação ou um de saber sobre um objeto de desejo, organiza-se a partir de um fazer (querer, saber e poder) pressuposto, ao qual deverá corresponder no destinatário um querer do querer, saber do poder e poder do poder igualmente pressupostos.

Retomando a perspectiva greimasiana de estudos bíblicos, tal como exposta por Thériault (2006) e Panier (2008), nosso trabalho tem como objetivo específico depreender mecanismos de construção do sentido de alguns excertos extraídos do Antigo e do Novo Testamento, tidos como cenas fundadoras dos enunciados de divulgação e de fidelização religiosa. 


\section{Análise Semiótica dos textos bíblicos}

\subsection{Análise do discurso fundador: a narrativa bíblica de Caim e Abel (Gn 4, 1-16) T2}

O homem se uniu a Eva, sua mulher, ela concebeu e deu à luz Caim, dizendo: "Ganhei um homem com a ajuda do Senhor". Tornou a dar à luz e teve Abel, irmão de Caim. Abel tornouse pastor de ovelhas e Caim pôs-se a cultivar o solo. Aconteceu, tempos depois, que Caim apresentou ao Senhor frutos do solo como oferta. Abel, por sua vez, ofereceu os primeiros cordeirinhos e a gordura das ovelhas. E o Senhor olhou para Abel e sua oferta, mas não deu atenção a Caim com sua oferta. Caim ficou irritado e com o rosto abatido. Então o Senhor perguntou a Caim: "Por que andas irritado e com o rosto abatido? Não é verdade que, se fizeres o bem, andarás de cabeça erguida? E se fizeres o mal, não estará o pecado espreitandote à porta? A ti vai seu desejo, mas tu deves dominá-lo". Caim disse a seu irmão Abel: "Vamos ao campo!" Mas, quando estavam no campo, Caim atirou-se sobre seu irmão Abel e o matou. O Senhor perguntou a Caim: "Onde está teu irmão Abel?" Ele respondeu: "Não sei. Acaso sou o guarda do meu irmão?" - "Que fizeste?", perguntou ele. "Do solo está clamando por mim a voz do sangue do teu irmão! Por isso, agora serás amaldiçoado pelo próprio solo que engoliu o sangue do teu irmão que tu derramaste. Quando cultivares o solo, ele te negará seus frutos e tu virás a ser um fugitivo, vagueando sobre a terra". Caim disse ao Senhor: "Meu castigo é grande demais para que eu o possa suportar. Se hoje me expulsas deste chão, devo esconder-me de ti, quando estiver fugindo e vagueando pela terra; quem me encontrar vai matar-me". Mas o Senhor lhe disse: "Se matarem Caim, ele será vingado sete vezes". O Senhor pôs então um Sinal em Caim, para que, ninguém, ao encontrá-lo, o matasse. Caim afastou-se da presença do Senhor e foi habitar na região de Nod, a leste do Éden (Gn 4, 1-16, BÍBLIA SAGRADA, CNBB, 2007, p. 18).

A análise não poderia deixar de incluir o livro de Gênesis (Gn). A tradição judaica designa esse livro pelas palavras iniciais bereshit "no princípio", o que remete ao seu significado enquanto "origem" (do mundo e da humanidade).

A narrativa bíblica de Caim e Abel (Gn 4, 1-16) institui-se como fonte primeira e fiadora do discurso instrucional do enunciado da encíclica "Evangelium Vitae", objeto de análise do terceiro Capítulo desta tese, graças ao caráter de autoridade proporcionado pela Palavra Revelada. A encíclica apresenta esta narrativa bíblica como o relato inaugural da violência contra a vida.

Reproduzimos, abaixo, o excerto da encíclica que apresenta o discurso fundador de Gênesis por meio do procedimento interdiscursivo da citação. Dessa forma, a fim de esclarecer como os recursos temáticos e figurativos do texto de fundação se encontram retomados no enunciado da encíclica (Cap. III), procedemos, inicialmente, à análise semiótica do discurso da narrativa bíblica citado por esse enunciado. 
O Evangelho da vida, que ressoa, logo ao princípio, com a criação do homem à imagem de Deus para um destino de vida plena e perfeita (cf. Gn 2, 7; Sab 9, 2-3), vê-se contestado pela experiência dilacerante da morte que entra no mundo, lançando o espectro da falta de sentido sobre toda a existência do homem. A morte entra por causa da inveja do diabo (cf. Gn 3, 1.45 ) e do pecado dos primeiros pais (cf. Gn 2, 17; 3, 17-19). E entra de modo violento, através do assassínio de Abel por obra do seu irmão: "Logo que chegaram ao campo, Caim levantou a mão contra o irmão Abel e matou-o" $(G n 4,8)$. Este primeiro assassínio é apresentado, com singular eloquência, numa página paradigmática do Livro do Gênesis: página transcrita cada dia, sem cessar e com degradante repetição, no livro da história dos povos. Queremos ler de novo, juntos, esta pagina bíblica, que, apesar do seu aspecto arcaico e extrema simplicidade, se apresenta riquíssima de ensinamentos.

\begin{abstract}
Abel foi pastor; e Caim, lavrador. Ao fim de algum tempo, Caim apresentou ao Senhor uma oferta de frutos da terra. Por seu lado, Abel ofereceu primogênitos do seu rebanho e as gorduras deles. O Senhor olhou favoravelmente para Abel e para a sua oferta, mas não olhou para Caim nem para a sua oferta. Caim ficou muito irritado e o rosto transtornou-se-lhe. $O$ Senhor disse a Caim: "Porque estás zangado e o teu rosto abatido? Se procederes bem, certamente voltarás a erguer o rosto; se procederes mal, o pecado deitar-se-á à tua porta e andará a espreitar-te. Cuidado, pois ele tem muita inclinação para ti, mas deves dominá-lo". Entretanto, Caim disse a Abel, seu irmão: "Vamos ao campo". Porém, logo que chegaram ao campo, Caim levantou a mão contra o irmão Abel e matou-o.O Senhor disse a Caim: "Onde está Abel, teu irmão?" Caim respondeu: "Não sei dele. Sou, porventura, guarda do meu irmão?" O Senhor replicou: "Que fizeste? A voz do sangue do teu irmão clama da terra até Mim. De futuro, serás maldito sobre a terra que abriu a sua boca para beber da tua mão o sangue do teu irmão. Quando a cultivares, negar-te-á as suas riquezas. Serás vagabundo e fugitivo sobre a terra". Caim disse ao Senhor: "A minha culpa é grande demais para obter perdão! Expulsas-me hoje desta terra; obrigado a ocultar-me longe da tua face, terei de andar fugitivo e vagabundo pela terra, e o primeiro a encontrar-me matar-me-á". O Senhor respondeu: "Não, se alguém matar Caim, será castigado sete vezes mais". E o Senhor marcou-o com um sinal, a fim de nunca ser morto por quem o viesse a encontrar. Caim afastou-se da presença do Senhor e foi residir na região de Nod, ao oriente do Éden » (Gn 4, 2-16) (JOAO PAULO II, 2005, p.18-19)
\end{abstract}

Tomando por base o enunciado fundador, apreendido de forma intertextual no enunciado da encíclica (divulgação religiosa), observamos que a oposição semântica fundamental é estabelecida entre os termos contrários (vida e morte) e seus contraditórios (não-morte e não-vida), que se relacionam, por sua vez, aos termos integração e transgressão. O termo "morte" é representado pelo domínio das pulsões individuais do indivíduo e o termo "vida" pelo domínio sagrado da religião e da comunhão com os valores propostos pelo enunciador divino.

Os termos do quadrado semiótico são axiologizados dentro da ideologia católica da seguinte forma: os termos (vida e integração) são axiologizados com valores eufóricos e os termos (morte e transgressão) são axiologizados com valores disfóricos.

Ao adotarmos a posição do narrador da narrativa bíblica de Caim e Abel, vemos que a operação que vai da não transgressão à integração manifesta uma tendência euforizante, por 
oposição à operação que vai da não integração à transgressão, efetuada na narrativa, e de tendência disforizante. Observamos, na narrativa bíblica, a presença da disforia que marca a passagem das continuidades às descontinuidades com a geração das tensões. A narrativa se desenvolve por meio de uma contenção inicial (parada da continuação), na qual o sujeito, ao não ser recompensado e movido pelo ciúme, nega o contrato de manipulação exercido pelo destinador divino. A transgressão realiza-se por meio da retenção (continuação da parada), expressa pelo antiprograma narrativo desenvolvido pelo sujeito ao executar seu próprio irmão, culminando na distensão (parada da parada) com o reconhecimento da culpa pela performance executada.

Inicialmente, no percurso do destinador-manipulador, temos uma espécie de contrato (manipulação pressuposta) entre as funções sintáticas de destinador-manipulador (o Senhor) e de destinatário-manipulado (irmãos: Caim e Abel). Segundo esse contrato pressuposto, o "Senhor" manipula os actantes-sujeitos (irmãos) a dever-fazer, ou seja, a dever apresentar sacrifícios ao Senhor.

O acordo entre o destinador-manipulador e o destinatário-sujeito pressupõe que ambos partilhem do mesmo quadro axiológico de valores. A performance se realiza, os actantessujeitos cumprem o contrato e apresentam sacrifícios ao Senhor. Abel oferece os "primogênitos do rebanho e a gordura deles" e Caim proporciona a "oferta de frutos da terra".

Após o percurso de ação do sujeito, efetiva-se a atividade do destinador-julgador. Este, ao realizar o seu fazer interpretativo, estabelece a seguinte sanção cognitiva de reconhecimento: Abel é reconhecido por sua performance, enquanto Caim não obtém reconhecimento.

No percurso do sujeito, Caim desempenha vários papéis actanciais: sujeito do quererfazer (querer cumprir o contrato pressuposto), do saber-fazer e do poder-fazer (tem a competência necessária para executar a performance) e do querer-ser (quer ser recompensando).

Ainda no percurso do destinador-manipulador, há um programa de doação de competência pressuposto. Por meio desse PN de aquisição de competência pressuposto, poder e saber são atribuídos a Caim para dominar o pecado e agir conforme os preceitos divinos. Caim tem o saber-fazer, o dever-fazer e o poder-fazer necessários para dominar o pecado.

Entretanto, efeitos de sentido afetivos ou modulações passionais orientam o percurso efetuado pelo destinatário sujeito (Caim) ao longo da narrativa. 
A narrativa de "Caim e Abel" se desenvolve, inicialmente, em torno de uma expectativa fiduciária, uma espera baseada na confiança. A expectativa fiduciária, dado o caráter intersubjetivo proposto, põe o sujeito em relação a outros sujeitos $\left(S_{1} \rightarrow S_{2}\right)$.

No enunciado considerado, a expectativa fiduciária pressupõe uma relação intersubjetiva entre o "Senhor" e "Caim". Essa expectativa fiduciária de Caim relativa ao Senhor vai transformar Caim, de sujeito desejoso do reconhecimento, em sujeito disjunto com o objeto modal querer-ser reconhecido.

Temos, inicialmente, o descontentamento do sujeito, frustrado em suas esperanças, acompanhado de um estado passional definido como um "sentimento penoso", um sentimento de falta que tem como característica a necessidade de elaboração de um PN da liquidação da falta. O descontentamento se apresenta como o pivô passional ao subsumir o desenvolvimento das estruturas passionais que constituem o sintagma passional da "cólera" (GREIMAS, 1983, p. 226).

Desse modo, vemos que o percurso de variação de tensividade organiza-se segundo um aumento de tensão: relaxamento $\rightarrow$ intensão $\rightarrow$ tensão.

Essa variação de tensividade realiza, na narrativa, o seguinte percurso passional: confiança $\rightarrow$ decepção $\rightarrow$ ciúme $\rightarrow$ inveja $\rightarrow$ cólera $\rightarrow$ revolta (liquidação da falta).

Caim deixa-se manipular, por tentação, pelo antiprograma narrativo pressuposto representado pelo pecado. As paixões do ciúme, da ira, da cólera e da inveja fazem com que ele seja induzido a executar o primeiro fratricídio, na raiz da violência contra o próximo. Caim instala-se como sujeito mediante a determinação do querer-fazer, ou seja, querer liquidar a falta sofrida. A restituição da falta é dada por intermédio de um programa de ação pautado por um desejo de vingança. Esta, definida como a necessidade ou o desejo de se vingar, não se constitui apenas de "uma simples liquidação da falta que situaria o PN no nível da circulação dos objetos de valor, mas de uma questão entre sujeitos, dos quais, um deve ser 'indenizado moralmente' e o outro, 'punido"”17 (Idem, p. 241).

Caim realiza-se como sujeito revoltado e, dotado das modalidades do poder-fazer e do querer-fazer, pode autoafirmar-se pela possibilidade de destruição do rival (vingança).

\footnotetext{
${ }^{17}$ O PN de vingança permanece, não obstante, um programa de compensação, mas esta última se realiza no nível das 'paixões' e o equilíbrio intersubjetivo buscado é uma espécie de equivalência passional. Se um sujeito S1 sofre, então é conveniente infringir a 'pena', quer dizer, a punição e a dor, ao mesmo tempo, ao sujeito S2 para fazê-lo sofrer outro tanto. A vingança, como se vê, é a princípio um reequilíbrio de sofrimentos entre dois sujeitos antagonistas. Um tal equilíbrio de sofrimentos é um fenômeno intersubjetivo, uma regulação social das paixões (GREIMAS, 1983, p. 241).
} 
$\mathrm{O}$ actante sujeito sancionado negativamente se decepciona e, por meio dos percursos passionais da revolta, da inveja, da ira e do ódio adquire o poder-fazer e o querer-fazer o mal a alguém, o rival.

A rivalidade remete, de acordo com Greimas (1993, p. 174), à "situação de duas ou mais pessoas que disputam por alguma coisa (sobretudo o primeiro lugar, a primeira fileira)". Encontram-se, assim, os papéis actanciais dos sujeitos de estado concorrentes $\left(\mathrm{S}_{1} / \mathrm{S}_{2}\right)$ entre os quais circula o objeto de valor (poder-ser e querer-ser reconhecido pelo Senhor). Caim é modalizado pela paixão intersubjetiva do ciúme pelo querer-ser (possessão) e pelo dever-ser (apego). A relação entre os irmãos é movida pela rivalidade, calcada em sentimentos de inveja e ódio em Caim. A inveja de um irmão pelo outro desencadeia um estado de alma de paixões malevolentes. Dessa forma, desenvolve-se a narrativa da rivalidade entre irmãos, segundo a qual "para melhor expressar o poder soberano, absoluto e indivisível só restava a alternativa do fratricídio" (GREIMAS, 2004, p. 26).

Caim, como sujeito ressentido, revolta-se; e, munido do poder-fazer (poder transformador de estados: da disjunção à junção), cumpre a ação, com a performance do assassínio de seu irmão. Por intermédio dessa performance, Caim executa a seguinte transformação de estados: a) Abel: sujeito conjunto com a vida e com a recompensa divina passa a $\rightarrow$ um sujeito em disjunção com a vida; b) Caim: sujeito disjunto com o poder-ser passa $\mathrm{a} \rightarrow$ um sujeito conjunto com o poder-ser.

Caim, ao matar Abel por ciúmes da preferência de Deus, adquire o poder-ser (soberania) necessário, concretizando o programa de liquidação da falta. Segue-se, à realização da performance, a rapidez e a aceleração da progressão do mal.

Terminado o percurso da ação do sujeito, tem início, na narrativa, o percurso do destinador-julgador e, consequentemente, da atividade de sanção. Ao efetivar o seu fazer interpretativo, o destinador-julgador avalia as etapas da narrativa executadas por Caim.

Após a pergunta do destinador-julgador “Onde está Abel, teu irmão?”, e da resposta de Caim “Não sei dele. Sou, porventura, guarda do meu irmão?”, segue a réplica do Senhor, “Que fizeste?”, com a figura da "voz do sangue do teu irmão clama da terra até Mim”. Essa figura é suficiente para o desmascaramento do sujeito por parte do destinador-julgador.

A evocação da "voz do sangue que clama do solo" possui origem na crença judaica, segundo a qual o sangue humano derramado e não coberto de terra clamaria aos céus (BRUNEL, 1997, p.139-140). 
O segredo e a mentira são desmascarados pelo destinador-julgador (o Senhor). Com isso, o destinador denuncia o comportamento mentiroso e ilusório de Caim aplicando-lhe uma sanção negativa. Caim, após executar a performance do assassínio de seu irmão, é sancionado negativamente pelo destinador divino. Realiza-se, na narrativa, uma sanção cognitiva e pragmática com a punição: ser amaldiçoado por Deus, como também pela terra, que lhe recusará os seus frutos (Gn 4, 11-12). Caim é punido: habitará em terras agrestes e desertas. Segue-se um PN de privação transitiva por espoliação, no qual o Senhor tira de Caim os objetos valor "riquezas da terra" e "presença do Senhor". Caim reconhece sua culpa e realizase, por fim, um PN de doação de competência, no qual o Senhor dota Caim com um sinal (objeto modal), conforme o qual Caim adquire o não-poder-ser morto por quem o encontrasse.

Ressaltamos o comportamento patêmico desse enunciador, "que perdoa e condena ao mesmo tempo, gera atritos e paixões, como a inveja de Caim, que mata o irmão Abel" (MENDES, 2009, p. 12). Tomemos a afirmação de Mendes (2009), ao elaborar a análise semiótica das paixões no Antigo testamento. Vejamos como a autora evidencia a figurativização da imagem do hiperenunciador divino instaurado no enunciado:

Instaurando-se como um "juiz implacável" e movido por um tumulto de paixões, o criador é figurativizado no discurso do Antigo Testamento como aquele que detém o poder, enquanto as criaturas que habitam o Canaã são sujeitos que também disputam o poder, sustentado nesse caso pela posse da terra prometida (MENDES, 2009, p. 12).

Com relação ao exame das estruturas discursivas do referido texto, observamos que este se realiza pela utilização de uma debreagem enunciva. As estratégias do enunciador constituem-se na ocultação do eu-aqui-agora, ancorando os movimentos do sentido nos atores do enunciado, num tempo figurativizado como o tempo do "então" e num espaço topicalizado como o espaço do "alhures". Tem-se a emergência dos atores do enunciado por meio de um discurso que parece se enunciar sozinho. A história bíblica considerada, ao ser apoiada no texto figurativo, é pautada por uma construção mítica, segundo a qual o crime, persistente fato social, é representado em nossa cultura pelo episódio bíblico de Caim e Abel.

No que diz respeito aos procedimentos de actorialização presentes no enunciado fundador bíblico considerado, notamos a presença de um narrador implícito que dá voz aos actantes do enunciado, instalando-os no discurso por meio de uma debreagem interna 
enunciativa de segundo grau. Essa debreagem dá-se pela presença do discurso direto ${ }^{18}$ instalado entre aspas, que instaura o diálogo entre os actantes representados pelo Senhor e Caim.

Desse modo, o discurso direto é resultante da debreagem interna enunciativa de segundo grau, por meio da qual o narrador delega voz aos actantes do enunciado e projeta duas instâncias enunciativas autônomas, concernentes à presença de dois atos enunciativos, duas vozes: a do narrador e a do personagem (interlocutor). Mediante emprego do discurso direto, recria-se a situação da enunciação por intermédio do narrador.

Para fazer emergir os atores do enunciado, ao introduzir o discurso direto, o narrador se enuncia por meio de um verbo dicendi (de dizer) ${ }^{19}$ :

O Senhor disse a Caim: "Onde está Abel, teu irmão?" Caim respondeu: "Não sei dele. Sou, porventura, guarda do meu irmão?" (JOAO PAULO II, 2005, p. 19, grifos nossos).

Com relação à temporalização, notamos, na fala do narrador, a presença de verbos no pretérito perfeito 2, que indicam a pontualidade e o término das ações executadas, tal como:

Abel foi pastor; e Caim, lavrador. Ao fim de algum tempo, Caim apresentou ao Senhor uma oferta de frutos da terra. Por seu lado, Abel ofereceu primogênitos do seu rebanho e as gorduras deles. O Senhor olhou favoravelmente para Abel e para a sua oferta, mas não olhou para Caim nem para a sua oferta (JOAO PAULO II, 2005, p. 19, grifos nossos).

A ambientação correspondente aos espaços nos quais se movimentam os personagens encontra-se organizada no enunciado considerado em função de dois pontos instalados no interior do texto: o "campo" no qual se desenvolve o assassínio de Abel (espaço do fratricídio) e a região de Nod, ao oriente do Éden (espaço de afastamento e errância). A partir desses pontos instalados no interior do texto, há uma movimentação dos personagens nesse espaço. Observamos a modificação de suas posições dentro dessa categoria espacial, com o movimento de afastamento pelo qual Caim é punido, sendo obrigado a ocultar-se diante do Senhor e habitar a região de Nod.

\footnotetext{
18 "O discurso direto é resultado de uma debreagem interna (em geral de segundo grau), em que o narrador delega voz a um actante do enunciado. Possui duas instâncias enunciativas, dois níveis de eu: o do narrador e o do interlocutor. O discurso direto é um simulacro da enunciação construído por intermédio do discurso do narrador. [...] O discurso direto, em geral, cria um efeito de sentido de realidade, pois dá a impressão de que o narrador está apenas repetindo o que disse o interlocutor" (FIORIN, 2002, p. 72-74).

19 "O discurso reportado deve ser marcado, para que o enunciatário perceba a distinção entre discurso citante e citado. As marcas são diferentes no texto oral ou escrito. A marca mais importante, sem dúvida, é o verbo introdutor, em geral um verbum dicendi" (FIORIN, 2002, p.77).
} 
Verificamos, portanto, que a narrativa bíblica de Caim e Abel caracteriza-se como um texto figurativo, na medida em que: "trata de personagens concretizados semanticamente que atuam num tempo e espaço específicos" (CARVALHO, 2005, p. 43).

Vejamos como os valores assumidos pelo sujeito da narrativa são disseminados segundo percursos temáticos e revestidos por percursos figurativos. Elencamos, a seguir, os temas que compõem a narrativa e, em seguida, explicitamos o revestimento figurativo decorrente.

a) Inimizade entre irmãos (configuração discursiva da rivalidade). Esse tema recebe o investimento figurativo pautado pela oposição entre os atores (Caim e Abel). A oposição entre eles desenvolve-se mediante duas isotopias figurativas distintas e que configuram oposições simétricas: agricultura (papel temático do lavrador - sedentário) em Caim vs. pecuária (papel temático de pastor - nômade) em Abel. Destaque das figuras da isotopia agrícola: "lavrador", "oferta de frutos da terra"; isotopia pecuária: "primogênitos do seu rebanho"; "gorduras deles".

b) Rivalidade entre o bom e o mal. Esse tema recebe o investimento figurativo da rivalidade entre os irmãos. Caim é representado como aquele que tem inclinação ao pecado, por oposição a Abel, considerado bom e reconhecido pelo Senhor.

c) Oposição entre o Bem e o Mal. O narrado apresenta um caráter binário, segundo o qual a narrativa bíblica se constrói mediante uma série de categorias em oposição. O texto orienta a realidade consoante dois princípios principais: o bem, proveniente da integração ao sistema de valores propostos por Deus, e o mal, proveniente de entidades demoníacas. O mal é figurativizado como o pecado, entendido como transgressão da lei divina.

d) Livre preferência de Deus pelos mais novos e fracos: figurativizado pela preferência do Senhor por Abel.

e) Fé no sacrifício: figurativizado pelo olhar favorável demonstrado pelo Senhor às ofertas de Abel. 
f) Onisciência divina: figurativizado pela "voz do sangue do teu irmão clama da terra até mim", de acordo com a qual Deus já sabia que Caim havia cometido o pecado.

g) Manutenção dos valores divinos: figurativizado pelo bom proceder. Caim estaria, inicialmente, dotado do saber-fazer, dever-fazer e poder-fazer necessários para dominar o pecado.

h) Pecado original (crime). Figurativizado pelo fratricídio: "terra que abriu a sua boca para beber da tua mão o sangue do teu irmão".

i) Errância (configuração discursiva da errância). Caim, antes sedentário, é condenado a ser nômade, à errância. Figurativiza-se esse tema por: "andar fugitivo"; "vagabundo; "região de Nod, ao oriente do Éden".

j) Punição divina: figurativizado com a maldição imposta por Deus a Caim: "De futuro, serás maldito sobre a terra";

k) Nova integração divina (redenção). Figurativizado por: "reconhecimento da culpa"; "sinal".

No terceiro Capítulo desta tese, procederemos à análise do enunciado da encíclica a fim de evidenciar como esses temas e figuras se encontram retomados e atualizados pelo discurso papal.

\subsection{Análise Semiótica da Narrativa de Atos dos Apóstolos (At, 1-3)}

Reproduzimos, a seguir, o excerto da narrativa considerado para análise ${ }^{20}$ :

\footnotetext{
${ }^{20}$ Os números antes de cada segmento correspondem à indicação do número do capítulo em negrito (por exemplo, Atos dos Apóstolos, capítulo 1) e dos versículos bíblicos, indicados em sobrescrito.
} 
Bíblia Sagrada: Atos dos Apóstolos (At, 1-3)

\section{"EM JERUSALÉM, NA JUDÉIA E NA SAMARIA"}

\section{A promessa do Espírito Santo}

1. ${ }^{1 .}$ No meu primeiro livro, ó Teófilo, tratei de tudo que Jesus fez e ensinou, desde o começo ${ }^{2}$ até o dia em que foi elevado ao céu, depois de ter dado instruções, pelo Espírito Santo, aos apóstolos que havia escolhido. ${ }^{3 .}$ Depois da sua paixão, Jesus mostrou-se vivo a eles, com numerosas provas. Apareceu-lhes por um período de quarenta dias, falando do Reino de Deus.

4. Ao tomar a refeição com eles, deu-lhes esta ordem: "Não vos afasteis de Jerusalém, mas esperai a realização da promessa do Pai, da qual me ouvistes falar, quando eu disse: ${ }^{5}$. 'João batizou com água; vós, porém, dentro de poucos dias sereis batizados com o Espírito Santo"”.

\section{Jesus elevado aos céus}

6. Então, os que estavam reunidos perguntaram a Jesus: "Senhor, é agora que vais restabelecer o Reino para Israel?" 7. Jesus respondeu: "Não cabe a vós saber os tempos ou momentos que o Pai determinou com a sua autoridade. ${ }^{8}$ Mas recebereis o poder do Espírito Santo que virá sobre vós, para serdes minhas testemunhas em Jerusalém, por toda a Judéia e Samaria, e até os confins da terra". ${ }^{9}$ Depois de dizer isto, Jesus foi elevado, à vista deles, e uma nuvem o retirou aos seus olhos. ${ }^{10}$. Continuavam olhando para o céu, enquanto Jesus subia. Apresentaram-se a eles então dois homens vestidos de branco, ${ }^{11 .}$ que lhes disseram: "Homens da Galiléia, por que ficais aqui, parados, olhando para o céu? Esse Jesus que, do meio de vós, foi elevado ao céu, virá assim, do mesmo modo como o vistes partir para o céu".

\section{A COMUNIDADE EM JERUSALÉM}

12. Então os apóstolos deixaram o monte das Oliveiras e voltaram para Jerusalém, à distância que se pode andar num dia de sábado. ${ }^{13}$ Entraram na cidade e subiram para a sala de cima onde costumavam ficar. Eram Pedro e João, Tiago e André, Filipe e Tomé, Bartolomeu e Mateus, Tiago, filho de Alfeu, Simão Zelota e Judas, filho de Tiago. ${ }^{14 .}$ Todos eles perseveravam na oração em comum, junto com algumas mulheres - entre elas, Maria, mãe de Jesus - e com os irmãos dele.

\section{Eleição de Matias}

15. Naqueles dias, estava reunido um grupo de mais ou menos cento e vinte pessoas. Pedro levantou-se no meio dos irmãos e disse: ${ }^{16 . ~ " I r m a ̃ o s, ~ e r a ~ n e c e s s a ́ r i o ~ q u e ~ s e ~ c u m p r i s s e ~ o ~ q u e ~ o ~}$ Espírito Santo, por meio de Davi, na Escritura, anunciou acerca de Judas, que se tornou o guia daqueles que prenderam Jesus. ${ }^{17}$. Ele era um dos nossos e foi incumbido do mesmo ministério 18. Ele até comprou um campo com o salário da maldade, mas caiu morto, de bruços, arrebentado pelo meio, espalhando-se todas as suas vísceras. ${ }^{19} \mathrm{O}$ fato se tornou conhecido de todos os habitantes de Jerusalém. Por isso, aquele campo chama-se na língua deles Hacéldama, quer dizer, Campo do Sangue. ${ }^{20 .}$ De fato, no livro dos Salmos está escrito: 'Fique deserta a sua morada, e não haja quem nela habite!' E ainda: 'Que outro receba o seu encargo'. ${ }^{21 .}$ Há homens que nos acompanharam durante todo o tempo em que o Senhor Jesus 
viveu no meio de nós, ${ }^{22 .}$ a começar pelo batismo de João até o dia em que foi elevado do meio de nós. Agora, é preciso que um deles se junte a nós para ser testemunha da sua ressurreição". 23. Apresentaram então dois homens: José, chamado Barsabás, que tinha o apelido de Justo, e Matias. ${ }^{24 .}$ Em seguida, fizeram esta oração: "Senhor, tu conheces os corações de todos. Mostra-nos qual destes dois escolheste ${ }^{25}$ para ocupar, neste ministério e apostolado, o lugar que Judas abandonou para ir ao lugar que lhe cabia". ${ }^{26 .}$ Tiraram então a sorte entre os dois. A sorte caiu em Matias, o qual foi acrescentado ao número dos onze apóstolos.

\section{Pentecostes: manifestação do espírito}

2. ${ }^{1 .}$ Quando chegou o dia de Pentecostes, os discípulos estavam todos reunidos no mesmo lugar. ${ }^{2}$ De repente, veio do céu um ruído como de um vento forte, que encheu toda a casa em que se encontravam. ${ }^{3 .}$ Então apareceram línguas como de fogo que se repartiram e pousaram sobre cada um deles. ${ }^{4}$. Todos ficaram cheios do Espírito Santo e começaram a falar em outras línguas, conforme o Espírito lhes concedia expressar-se. ${ }^{5 .}$ Residiam em Jerusalém judeus devotos, de todas as nações que há debaixo do céu. ${ }^{6}$ Quando ouviram o ruído, reuniu-se a multidão, e todos ficaram confusos, pois cada um ouvia os discípulos falar em sua própria língua. ${ }^{7}$ Cheios de espanto e de admiração, diziam: "Esses homens que estão falando não são todos galileus? ${ }^{8}$. Como é que nós os escutamos na nossa língua de origem? ${ }^{9}$. Nós, que somos partas, medos e elamitas, habitantes da Mesopotâmia, da Judéia e da Capadócia, do Ponto e da Ásia, ${ }^{10}$ da Frígia e da Panfília, do Egito e da parte da Líbia próxima de Cirene, e os romanos aqui residentes, ${ }^{11}$ judeus e prosélitos, cretenses e árabes, todos nós os escutamos anunciando as maravilhas de Deus em nossa própria língua!" ${ }^{12 .}$ Todos estavam pasmados e perplexos, e diziam uns aos outros: "Que significa isso?" 13. Mas outros caçoavam: "Estão bêbados de vinho doce".

\section{O anúncio de Pedro, ou querigma}

14. Pedro, de pé, junto com os onze apóstolos, levantou a voz e falou à multidão: "Homens da Judéia e todos vós, que residis em Jerusalém, seja do vosso conhecimento o que vou dizer. Escutai-me com toda a atenção. ${ }^{15}$. Estes aqui não estão embriagados, como podeis pensar, pois estamos ainda em plena manhã. ${ }^{16}$ Está acontecendo o que foi anunciado pelo profeta Joel: ${ }^{17}$. 'Nos últimos dias, diz o Senhor, derramarei do meu Espírito sobre toda carne, e vossos filhos e filhas profetizarão, os vossos jovens terão visões e os vossos anciãos terão sonhos; ${ }^{18 .}$ mesmo sobre os meus escravos e escravas derramarei do meu Espírito, naqueles dias, e profetizarão. ${ }^{19}$ E mostrarei prodígios no céu, em cima, e sinais na terra, em baixo, sangue e fogo e nuvem de fumaça. ${ }^{20}$ O sol se transformará em trevas e a lua, em sangue, antes que venha o grande e glorioso dia do Senhor. ${ }^{21 .} E$ todo aquele que invocar o nome do Senhor será salvo'. ${ }^{22 .}$ Homens de Israel, escutai estas palavras: Jesus de Nazaré foi um homem credenciado por Deus junto de vós, pelos milagres, prodígios e sinais que Deus realizou entre vós por meio dele, como bem o sabeis. ${ }^{23}$ Deus, em seu desígnio e previsão, determinou que Jesus fosse entregue pelas mãos dos ímpios, e vós o matastes, pregando-o numa cruz. ${ }^{24}$ Mas Deus o ressuscitou, libertando-o das angústias da morte, porque não era possível que ela o dominasse. ${ }^{25}$. Pois Davi diz a seu respeito: 'Eu via sempre o Senhor diante de mim, porque está à minha direita, para que eu não vacile. ${ }^{26}$. Por isso alegrou-se meu coração e exultou minha língua; mais ainda, minha carne repousará na esperança. ${ }^{27 .}$ Não abandonarás minha alma no reino da morte nem deixarás o teu Santo conhecer a decomposição. ${ }^{28 .}$ Deste-me a conhecer caminhos de vida e me encherás de alegria com a tua presença'. ${ }^{29}$ Irmãos, seja-me permitido dizer-vos, com toda liberdade, que o patriarca Davi morreu e foi sepultado, e seu sepulcro está entre nós até hoje. ${ }^{30}$ Ora, ele era profeta e sabia que Deus lhe havia jurado solenemente que um de seus descendentes se sentaria no seu trono.

31. Assim, ele previu a ressurreição do Cristo e é dela que disse: não foi abandonado no reino da morte, e sua carne não conheceu a decomposição. ${ }^{32}$. De fato, Deus ressuscitou este mesmo 
Jesus, e disso todos nós somos testemunhas. ${ }^{33 .}$ E agora, exaltado pela direita de Deus, ele recebeu o Espírito Santo que fora prometido pelo Pai e o derramou, como estais vendo e ouvindo. ${ }^{34}$. Pois Davi não subiu ao céu, mas ele diz: 'Disse o Senhor ao meu Senhor: senta-te à minha direita, ${ }^{35}$ até que eu ponha teus inimigos como apoio para teus pés'. ${ }^{36}$. Portanto, que todo o povo de Israel reconheça com plena certeza: Deus constituiu Senhor e Cristo a este Jesus que vós crucificastes".

\section{Primeiras conversões}

37. Quando ouviram isso, ficaram com o coração compungido e perguntaram a Pedro e aos outros apóstolos: "Irmãos, que devemos fazer?" 38. Pedro respondeu: "Convertei-vos, e cada um de vós seja batizado em nome de Jesus Cristo, para o perdão dos vossos pecados. E recebereis o dom do Espírito Santo. ${ }^{39}$. Pois a promessa é para vós e vossos filhos, e para todos aqueles que estão longe, todos aqueles que o Senhor, nosso Deus, chamar". " ${ }^{40 .}$ Com muitas outras palavras ainda, Pedro lhes dava testemunho e os exortava, dizendo: "Salvai-vos desta geração perversa!" ${ }^{41 .}$ Os que aceitaram as palavras de Pedro receberam o batismo. Naquele dia, foram acrescentadas mais ou menos três mil pessoas.

\section{A vida da primeira comunidade}

42. Eles eram perseverantes em ouvir o ensinamento dos apóstolos, na comunhão fraterna, na fração do pão e nas orações. ${ }^{43}$ Apossava-se de todos o temor, e pelos apóstolos realizavam-se numerosos prodígios e sinais. ${ }^{44 .}$ Todos os que abraçavam a fé viviam unidos e possuíam tudo em comum; ${ }^{45}$. vendiam suas propriedades e seus bens e repartiam o dinheiro entre todos, conforme a necessidade de cada um. ${ }^{46}$. Perseverantes e bem unidos, frequentavam diariamente o templo, partiam o pão pelas casas e tomavam a refeição com alegria e simplicidade de coração. ${ }^{47 .}$ Louvavam a Deus e eram estimados por todo o povo. E, cada dia, o Senhor acrescentava a seu número mais pessoas que seriam salvas.

Atos dos Apóstolos constitui um dos livros do Novo Testamento, em seguida aos Evangelhos. Nesse discurso, temos a narração do seguimento da história de Jesus expressa nos Evangelhos, sobretudo o de Lucas. Este é tido como um primeiro livro do qual a narrativa de Atos resume o objeto e retoma os últimos acontecimentos (aparição do ressuscitado e ascensão), encadeando-os à sequência do relato.

Procuramos demonstrar os mecanismos de construção do sentido do texto que fazem com que a narrativa de Atos possa ser considerada o primeiro relato de divulgação dos ideais cristãos.

Atos dos Apóstolos, presente no Novo Testamento, apresenta-se como um livro histórico de autoria do evangelista Lucas. O gênero desse discurso caracteriza-o como uma narrativa de atos ou práticas, tal como a literatura helenística reconhecia as narrativas de atos ou práticas de pessoas famosas, como Aníbal e Alexandre o Grande. A narrativa dos Atos apostólicos, de estilo lacônico e linguagem polida do narrador, assinala o caráter de testemunho e de conclamação da fé. 
A tradição atribui a Lucas a autoria do terceiro Evangelho e dos Atos dos Apóstolos. Entretanto, conforme ressalta Kurtz (1999, p. 143), há muitas controvérsias entre os biblistas a respeito de quem teria escrito o Evangelho, atribuído a Lucas, e os Atos dos Apóstolos.

Retomemos esses debates sob a questão teórica da autoria, tão cara aos estudos discursivos. A noção de autor compõe, para Foucault (1997, p. 33), "o momento forte de individuação na história das ideias, dos conhecimentos, das literaturas, na história da filosofia moderna, e na das ciências". A relação do texto com o seu autor aponta para essa figura que é, ao mesmo tempo, exterior e anterior. Quando pensamos no nome do autor "Lucas", ele não se estabelece como uma referência pura e simples. Ele é um nome próprio, palavra equivalente a uma série de atributos definidos em torno deste: o autor do Evangelho de Lucas e da Narrativa de Atos dos Apóstolos. Temos, segundo Foucault (Idem, p. 42), o nome próprio e o nome do autor situados nos polos da descrição e da designação. Entretanto, o nome do autor não se configura como um nome próprio exatamente como os outros. Foucault (Idem, p. 44) ressalta a singularidade paradoxal da autoria, afinal, ela não é simplesmente o elemento de um discurso. Ela assegura uma função classificativa, pois permite reagrupar, delinear e opor textos a outros. A autoria serviria, portanto, para caracterizar o modo de ser do discurso. Procuraremos delinear, assim, mediante um conjunto de traços recorrentes do plano do conteúdo e do plano de expressão, a imagem do narrador de Atos, enquanto efeito de identidade próprio a esse discurso. Como se caracteriza o éthos, a imagem do narrador do texto singular da narrativa de Atos?

A narrativa bíblica de Atos dos Apóstolos, embora seja considerada o primeiro relato das origens do cristianismo, não pode ser caracterizada como uma historiografia, no sentido contemporâneo do termo ${ }^{21}$. $\mathrm{O}$ narrador não tem a pretensão de fazer uma reconstituição científica dos fatos, mas, baseando-se em fontes fidedignas, procura evocar o sentido daquilo que aconteceu, além de prestar homenagem aos primeiros evangelizadores e fundadores das Igrejas Cristãs (BÍBLIA SAGRADA, CNBB, 2007, p. 1340).

Que expectativas os leitores do século I tinham sobre um livro que se propunha historiográfico, isto é, que procura registrar os acontecimentos e fatos históricos de seu tempo? Quais códigos de comunicação ligavam o enunciador aos enunciatários pressupostos

\footnotetext{
${ }^{21} \mathrm{O}$ sentido contemporâneo de historiografia diz respeito ao trabalho científico que tem como centro o trabalho do historiador designado a registrar os acontecimentos e fatos históricos, em correspondência ao princípio da objetividade.
} 
por esse discurso? A que regras obedecia a escritura da história na sociedade romana à qual Lucas pertencia? Essas são algumas questões sobre as quais se debruça Marguerat (2003, p. 24), exegeta que, amparado pelos métodos de interpretação da crítica histórica e da narratologia, procura depreender o sentido da narrativa bíblica de Atos, enquanto primeira história do cristianismo. Ainda que nosso arcabouço teórico seja orientado pela semiótica greimasiana, não deixaremos de vislumbrar alguns dos desenvolvimentos do pensamento do autor, na medida em que eles possam contribuir para a caracterização do éthos do narrador de Atos.

Para o autor, "fazer história é procurar as causas dos acontecimentos (o que nos leva de volta à noção de enredo, pois este consiste em estabelecer uma relação de causa e efeito entre os fatos)" (Idem, 2003, p. 24). Por historiografia entenderíamos, então, a busca de casualidades.

O prefácio do livro de Atos instaura no enunciado um endereçamento a um sujeito. Temos a referência ao narratário (Teófílo), indicada logo no início da narrativa: "No meu primeiro livro, ó Teófilo", (At, 1, 1-2, BÍBLIA SAGRADA, CNBB, 2007, p. 1342). Esse estilo prefacial pertencente à prosa técnica confirmaria a correspondência do escrito lucano ao padrão da historiografia greco-romana.

Para o autor, o leitor familiarizado com a narrativa de Atos encontraria aqui uma das normas segundo as quais Lucas teria subscrito sua narrativa. Outro traço fundamental da historiografia greco-romana, apontado pelo autor, é o seu papel edificador e a sua importância na educação.

Como poderemos depreender, na materialidade discursiva do enunciado, os traços que remetem a essa imagem de si? Ao concebermos o discurso como um conjunto de procedimentos argumentativos utilizados pelo enunciador para convencer o enunciatário, compreenderemos, mediante a análise a seguir, como esses procedimentos são empregados pelo enunciador para fazer-crer como verdadeiro seu enunciado e viabilizar, por parte do enunciatário (leitores cristãos), a adesão às normas e aos modelos a serem seguidos ${ }^{22}$. Deduziremos esses traços pela análise dos procedimentos argumentativos empregados pelo enunciado.

\footnotetext{
22 "A finalidade de todo ato de comunicação não é informar, mas persuadir o outro a aceitar o que está sendo comunicado. Por isso, o ato de comunicação é um complexo jogo de manipulação com vistas a fazer o interlocutário crer naquilo que se transmite. Por isso, ele é sempre persuasão" (FIORIN, 2005a, p. 75).
} 
No que diz respeito à análise narrativa de Atos, teremos Lucas como o destinador que busca transmitir um objeto de valor cognitivo: o saber a respeito da história da Igreja.

Mais do que um relato histórico (narrativa dos primórdios da Igreja), o texto se constitui como a transmissão do $O_{v}$ salvação para o sujeito: transmissão da boa nova, comunicação, divulgação.

Discursiviza-se, no enunciado, o plano divino da salvação e de como todos os acontecimentos expostos são respostas autênticas às promessas de Israel.

Está acontecendo o que foi anunciado pelo profeta Joel: ${ }^{17}$. "Nos últimos dias, diz o Senhor, derramarei do meu Espírito sobre toda carne, e vossos filhos e filhas profetizarão, os vossos jovens terão visões e os vossos anciãos terão sonhos; ${ }^{18}$ mesmo sobre os meus escravos e escravas derramarei do meu Espírito, naqueles dias, e profetizarão. ${ }^{19} \mathrm{E}$ mostrarei prodígios no céu, em cima, e sinais na terra, em baixo, sangue e fogo e nuvem de fumaça. ${ }^{20}$. O sol se transformará em trevas e a lua, em sangue, antes que venha o grande e glorioso dia do Senhor. 21. E todo aquele que invocar o nome do Senhor será salvo" (At, 2, 16-21, BÍBLIA SAGRADA, CNBB, 2007, p. 1344).

Podemos caracterizar esse discurso como o primeiro relato de divulgação dos ideais cristãos da Igreja Primitiva. Temos, assim, mediante a sequência da narrativa a exposição de como Pedro, Paulo e outros missionários cristãos realizaram a obra de Jesus de acordo com o seu plano salvífico. Ele demonstra a continuidade do relato entre a narrativa referente a Jesus e os apóstolos, dado como anúncio profetizado pelo Antigo Testamento.

No que concerne aos procedimentos argumentativos empregados, observamos a presença da argumentação pelo exemplo e a aquisição do $\mathrm{O}_{\mathrm{v}}$ salvação por parte do sujeito fiel, caso este siga os modelos estabelecidos e aja como um verdadeiro cristão por meio da adequada propagação do evangelho.

Se tomarmos como base os procedimentos argumentativos referentes às ligações que fundam a estrutura do real, estabelecidos por Perelman e Olbrechts-Tyteca (2005, p. 413), no que diz respeito ao fundamento pelo caso particular, a estratégia argumentativa empregada é a argumentação pelo exemplo.

A vida da primeira comunidade, um caso particular, é colocada como um exemplo, um modelo de conduta a ser imitada (Idem, p. 414).

42. Eles eram perseverantes em ouvir o ensinamento dos apóstolos, na comunhão fraterna, na fração do pão e nas orações. ${ }^{43}$. Apossava-se de todos o temor, e pelos apóstolos realizavam-se numerosos prodígios e sinais. ${ }^{44}$ Todos os que abraçavam a fé viviam unidos e possuíam tudo 
em comum; ${ }^{45}$ vendiam suas propriedades e seus bens e repartiam o dinheiro entre todos, conforme a necessidade de cada um. ${ }^{46 .}$ Perseverantes e bem unidos, freqüentavam diariamente o templo, partiam o pão pelas casas e tomavam a refeição com alegria e simplicidade de coração. ${ }^{47 .}$ Louvavam a Deus e eram estimados por todo o povo. E, cada dia, o Senhor acrescentava a seu número mais pessoas que seriam salvas (At, 2, 42-47, BÍBLIA SAGRADA, CNBB, 2007, p. 1345).

O comportamento dos membros da comunidade é exemplar por constituir um simulacro intersubjetivo da perseverança na realização de desígnios divinos. Temos a manutenção da aquisição do $\mathrm{O}_{\mathrm{v}}$ "graça divina" por parte daqueles que forem perseverantes em ouvir o ensinamento dos apóstolos.

Enquanto a comunidade adepta ao seguimento dos apóstolos é posta como modelo pelo exemplo, Judas constitui-se como o antimodelo de conduta a ser seguida. "Se a referência a um modelo possibilita promover certas condutas, a referência a um contraste, a um antimodelo permite afastar-se delas" (PERELMAN; OLBRECHTS-TYTECA, 2005, p. 417).

Pedro levantou-se no meio dos irmãos e disse: ${ }^{16 . ~ " I r m a ̃ o s, ~ e r a ~ n e c e s s a ́ r i o ~ q u e ~ s e ~ c u m p r i s s e ~ o ~}$ que o Espírito Santo, por meio de Davi, na Escritura, anunciou acerca de Judas, que se tornou o guia daqueles que prenderam Jesus. ${ }^{17}$. Ele era um dos nossos e foi incumbido do mesmo ministério ${ }^{18 .}$ Ele até comprou um campo com o salário da maldade, mas caiu morto, de bruços, arrebentado pelo meio, espalhando-se todas as suas vísceras. ${ }^{19}$. O fato se tornou conhecido de todos os habitantes de Jerusalém. Por isso, aquele campo chama-se na língua deles Hacéldama, quer dizer, Campo do Sangue (At, 1, 15-19, BÍBLIA SAGRADA, CNBB, 2007, p. 1345).

Judas é instaurado como o antiexemplo, modelo de conduta a ser rechaçado. A presença do contraexemplo faz parte da retórica didatizante desse discurso. A argumentação, ao contrapor contraexemplos às figuras exemplares, pode ser relacionada à necessidade proposta pelo discurso fundador bíblico de ensinar a "amar" e a "temer" a Deus. Temos uma manipulação por intimidação. A presença do contraexemplo a ser rechaçado (querer não ser) valoriza, pelo contraste, os demais sujeitos, tidos como exemplos a serem seguidos (querer ser).

O discurso fundador dos Atos dos Apóstolos apresenta uma aspectualização incoativa ao se estabelecer como referência básica para a instituição do domínio de divulgação dos ideais cristãos, em cumprimento às últimas palavras de Jesus no momento de sua ascensão: 
Mas recebeis o poder do Espírito Santo que virá sobre vós, para serdes minhas testemunhas em Jerusalém, por toda a Judéia e Samaria, e até os confins da terra (At, 1, 8, BÍBLIA SAGRADA, CNBB, 2007, p. 1342).

Essa conjunção com o objeto de valor modal $\left(\mathrm{O}_{\mathrm{m}}\right)$, representado pelo poder do Espírito Santo, dá-se por meio do programa narrativo de doação de competência realizado pela figura de Jesus Cristo, mediante a intermediação do Espírito Santo. A instituição do sacramento do batismo confere o poder necessário para que os apóstolos possam se tornar verdadeiros evangelizadores: "Ser testemunhas em Jerusalém", “em toda a Judéia e Samaria", "até os confins da terra". Temos a narrativa de divulgação dos ideais cristãos, por intermédio do anúncio da palavra de Deus e da difusão do cristianismo.

Realizamos, a seguir, o exame da sintaxe discursiva do referido enunciado instrucional dentro do discurso fundador. Estudamos as marcas da enunciação no enunciado, utilizandonos dos procedimentos de actorialização, temporalização e espacialização, referentes à instauração de pessoas, tempo e espaço no discurso.

No que diz respeito aos procedimentos de actorialização presentes nesta parte da narrativa bíblica, temos a presença de um narrador explícito (Lucas) que se dirige a certo Teófilo, narratário instaurado no enunciado.

No meu primeiro livro, ó Teófilo, tratei de tudo o que Jesus fez e ensinou, desde o começo até o dia em que foi elevado ao céu, depois de ter dado instruções, pelo Espírito Santo, aos apóstolos que havia escolhido (At, 1, 1-2, BÍBLIA SAGRADA, CNBB, 2007, p. 1342).

Por meio de uma debreagem interna enunciativa de segundo grau, apresentamos a instauração do diálogo entre os actantes representados por Jesus e os Apóstolos.

Então, os que estavam reunidos perguntaram a Jesus: "Senhor, é agora que vais restabelecer o Reino para Israel?" 7. Jesus respondeu: "Não cabe a vós saber os tempos ou momentos que o Pai determinou com a sua autoridade. ${ }^{8}$ Mas recebereis o poder do Espírito Santo que virá sobre vós, para serdes minhas testemunhas em Jerusalém, por toda a Judéia e Samaria, e até os confins da terra" ". (At, 1, 1-9, BÍBLIA SAGRADA, CNBB, 2007, p. 1343).

Notemos a emergência dos atores do enunciado, introduzidos em discurso direto pelo narrador por meio de um "verbo de dizer": "Então, os que estavam reunidos perguntaram a Jesus", "Jesus respondeu (...)" (grifos nossos). 
No que tange aos mecanismos de temporalização presentes no enunciado, verificamos a utilização do pretérito perfeito 2 , que procura assinalar um aspecto acabado, pontual às ações.

No meu primeiro livro, ó Teófilo, tratei de tudo que Jesus fez e ensinou, desde o começo (At, 1, 1, BÍBLIA SAGRADA, CNBB, 2007, p. 1342).

De fato, Deus ressuscitou este mesmo Jesus, e disso todos nós somos testemunhas (At, 2, 32, BÍBLIA SAGRADA, CNBB, 2007, p. 1342).

Ainda no que concerne à temporalização, notamos a presença de advérbios de tempo articulados em um sistema enuncivo, organizados em torno de um momento de referência (pretérito ou futuro), inscrito no enunciado (FIORIN, 2002, p. 162).

Esse sistema se exprime pelo uso do advérbio "então" que assinala a concomitância ao marco temporal pretérito instaurado no enunciado:

"Então os apóstolos deixaram o monte das Oliveiras" (At, 1, 12, BÍBLIA SAGRADA, CNBB, 2007, p. 1343).

"Então apareceram línguas como de fogo que se repartiram e pousaram sobre cada um deles" (At, 2, 3, BÍBLIA SAGRADA, CNBB, 2007, p. 1343).

Mantém-se o pretérito perfeito 2:

"Depois da sua paixão, Jesus mostrou-se vivo a eles, com numerosas provas" (At, 1, 3, BÍBLIA SAGRADA, CNBB, 2007, p. 1343).

"De repente, veio do céu um ruído como de um vento forte, que encheu toda a casa em que se encontravam" (At, 2, 3, BÍBLIA SAGRADA, CNBB, 2007, p. 1344).

No que diz respeito à subversão temporal, observamos a instauração da concomitância 1 pela concomitância 2 (presente pelo pretérito perfeito 2).

E agora, exaltado pela direita de Deus, ele recebeu o Espírito Santo que fora prometido pelo Pai e o derramou, como estais vendo e ouvindo. ${ }^{34}$ Pois Davi não subiu ao céu, mas ele diz: 'Disse o Senhor ao meu Senhor: senta-te à minha direita [...]" (At, 2, 33-36, BÍBLIA SAGRADA, CNBB, 2007, p. 1345).

A espacialização reconstrói a cena da enunciação por meio do uso de uma debreagem enunciva mediante a figurativização do espaço instaurado no interior da história bíblica. 
Temos dois pontos instituídos dentro do texto: "o monte das Oliveiras" e o retorno dos personagens à "Jerusalém".

12. Então os apóstolos deixaram o monte das Oliveiras e voltaram para Jerusalém, à distância que se pode andar num dia de sábado. ${ }^{13 .}$ Entraram na cidade e subiram para a sala de cima onde costumavam ficar (At, 1, 12-13, BÍBLIA SAGRADA, CNBB, 2007, p. 1343).

É interessante notar que a duração temporal da transposição espacial de um ponto a outro no enunciado não é medida cronologicamente, mas espacialmente "à distância que se pode andar num dia de sábado".

No que concerne à temática dos Atos (1-12), observamos a narração da vida da primeira comunidade reunida em torno de Pedro (primórdios do cristianismo) e o início de sua ascensão (primeiro relato de divulgação dos ideais cristãos) graças às ações missionárias de Felipe, dos Helenistas e do Próprio Pedro. Temos, portanto, no trecho em análise, a temática da origem e crescimento da Igreja em Jerusalém por intermédio do Espírito.

No que diz respeito ao modo específico de axiologizar valores, correspondentes aos preceitos de uma determinada formação ideológica, no caso, os valores propugnados pela ideologia religiosa católica e que serão materializados no nível discursivo do percurso gerativo do sentido, obtemos no enunciado a presença dos seguintes temas:
a) realização do plano divino de salvação;
b) ação do Espírito Santo por intermédio dos apóstolos,
c) salvação do povo de Deus;
d) triunfo dos ideais cristãos;
e) orientação divina do caminho cristão.

Com base nesses pressupostos, os resultados de nossa análise incidem na caracterização do enunciado divulgador bíblico de Atos como um enunciado definido segundo os parâmetros da "história da expansão dos ideais cristãos", o que projeta o papel específico do éthos do enunciador, orientado por meio de um tom de voz próprio à cena enunciativa pressuposta.

Lucas, figurativização do narrador instaurado no enunciado, escreve o relato não apenas como um simples historiador, mas como um líder pastoral, ao estabelecer uma norma 
à práxis de uma determinada comunidade de fé. Ele procura, além de fornecer o saber necessário à aquisição do histórico das origens do cristianismo, persuadir o leitor para a edificação e consolidação da fé.

Desse modo, a finalidade do enunciado fundador bíblico, ao apresentar a expansão da mensagem salvífica do cristianismo, mais do que dar sequência ao relato da história de Jesus, faz com que possamos caracterizá-lo como o primeiro relato de divulgação dos ideais cristãos. Observamos, assim, o éthos de um intelectual cristão, de um teólogo que pretende defender, construindo e não apenas transmitindo, as bases de uma doutrina universal. 


\section{Cap. II \\ DISCURSO DE FIDELIZAÇÃO RELIGIOSA: A EXPERIÊNCIA DA PALAVRA NA PRÁTICA CATÓLICA}

Desde os primórdios da Igreja, a leitura das Escrituras fez parte integrante da liturgia cristã, por um lado herdeira da liturgia sinagogal. Hoje ainda, é principalmente pela liturgia que os cristãos entram em contato com as Escrituras, particularmente durante a celebração eucarística de domingo.

Pontifícia Comissão Bíblica ${ }^{23}$

\footnotetext{
${ }^{23}$ Pontifícia Comissão Bíblica (2009, p. 148).
} 


\section{Estrutura do campo da prática de fidelização religiosa}

Dentro da perspectiva de exame dos enunciados pertencentes à fidelização religiosa, propomos, neste trabalho, examinar os mecanismos de produção do efeito de sentido afetivo ou passional, depreensíveis da prática religiosa católica. Procuramos, por meio deste Capítulo, definir o campo da prática religiosa no que se refere aos símbolos da tradição e aos ritos praticados por uma instituição determinada, no caso, a Igreja Católica.

Para a análise dos enunciados de fidelização religiosa, teremos como base os preceitos da semiótica greimasina tomada, sobretudo, no que diz respeito ao exame da dimensão passional do discurso (GREIMAS, 1993), seus recentes desenvolvimentos tensivos (ZILBERBERG, 2006) e a noção de "práticas semióticas" (FONTANILLE, 2008). Adotaremos, também, alguns conceitos advindos da Análise do Discurso Francesa, com a devida incorporação à teoria semiótica, dos quais destacamos as noções de participação (MAINGUENEAU, 2008) e de fórmula discursiva (KRIEG-PLANQUE, 2010).

Como o todo está nas partes, objetivamos estabelecer, mediante o exame dos enunciados de fidelização religiosa, recorrências que compõem a materialidade discursiva de uma totalidade: a enunciação de fidelização enquanto um éthos.

Cada enunciado de fidelização religiosa é, portanto, um unus (unidade integral) que remete a um totus que compreende a totalidade dos enunciados de fidelização religiosa.

Visamos demonstrar como se processam os diferentes graus de fidelização concernentes às práticas religiosas. Lembramos que retomamos a acepção de práticas semióticas de Fontanille (2008). Vejamos a seguinte definição do que o autor considera como o nível de pertinência dessas práticas.

As práticas recebem uma "forma" (constituintes) de sua confrontação com as outras práticas e, por isso, de um lado, integram os elementos materiais dos níveis inferiores (signos, textos, objetos) para torná-los elementos distintivos e pertinentes e lhes dar "sentido", e de outro lado, recebem um "sentido" de sua própria participação nos níveis superiores (estratégias e formas de vida) (FONTANILLE, 2008, p. 23).

Tencionamos, por intermédio da análise de enunciados de fidelização religiosa, delinear algumas considerações a respeito da estrutura aspectual e, por conseguinte, passional do crer, considerando o aspecto fiduciário envolvido nessa prática católica. Buscamos 
observar o status da dimensão passional do discurso, na medida em que "a paixão presentifica, no seio do discurso de acolhida, um conjunto de dados ao mesmo tempo tensivos e figurativos" (GREIMAS; FONTANILLE, 1993, p. 56).

Tomamos como base o termo simulacro, entendido enquanto um imaginário passional que atua aspectualizando o sujeito, ou seja, fazendo com que o sujeito queira ser de certo modo. Veremos, consequentemente, como se constitui o projeto de configuração passional ditado por esses enunciados, de tal modo que o sujeito deva agir de acordo com certos preceitos propostos por uma formação ideológica determinada, no caso, os valores propugnados pelo catolicismo.

A fim de delinear as características do campo da prática religiosa, e que compõem o nível das práticas simbólicas ritualizadas pela instituição religiosa, assumimos, como ponto de partida, as definições apresentadas por Bourdieu (1974) ao estabelecer a gênese e a estrutura do campo religioso. A constituição de um campo religioso como um sistema de práticas e representações reflete, segundo o autor, a necessidade de "moralização" e de "sistematização" das crenças e práticas religiosas (Idem, p. 34).

A prática de fidelização estabelece uma sequência canônica da ordem da difusão fidelização e rito - cujo objetivo é estimular a fidelidade a uma determinada práxis religiosa. Temos um processo de sistematização e de moralização das práticas e das representações religiosas que vai das Sagradas Escrituras, tida como discurso fundador, até a sua ritualização pelas práticas religiosas. Esse processo institui a constituição de instâncias especificamente organizadas, nas quais um corpo sacerdotal realiza a reprodução e difusão dos bens religiosos. Nele um patrimônio sagrado de símbolos da fé, deixados por Jesus, como quer essa mesma fé, é ritualizado pela Igreja mediante a instituição de práticas litúrgicas.

Caracteriza-se, assim, “a monopolização da gestão dos bens de salvação por um corpo de especialistas religiosos, socialmente reconhecidos como os detentores exclusivos da competência necessária à produção ou à reprodução de um 'corpus' de elementos sagrados e que constitui o campo religioso das práticas" (Idem, p. 39).

Para que pudéssemos demonstrar como se estabelece a transmissão ritualística, consoante a qual agentes autorizados e detentores do monopólio da fé (agentes religiosos) perpetuam a consolidação e a fidelização dos fiéis a determinadas práticas rituais, incorporamos à teoria semiótica a noção de espistemologia do rito, estabelecida pelo teórico da comunicação James Carey (2009, p. 13-36). A epistemologia do rito distingue-se como um 
conjunto de conceitos oriundos da teoria da comunicação e de disciplinas afins. Seu objetivo é desenvolver um processo comunicacional que tem em vista os objetos socioculturais, dentre os quais destacamos o domínio da religião.

Temos, conforme o autor, duas formas de conceber-se a comunicação: uma visão transmissiva, a que associamos os enunciados de divulgação religiosa, objeto do terceiro Capítulo desta tese, e uma visão ritualística, participativa da comunicação. Isso, pois, de acordo com Carey (2009, p. 13-36), o ritual tem como pressuposto a participação, a troca e a associação entre os fiéis, membros de uma fé comum.

A noção teórica de participação também tem suscitado grandes desenvolvimentos na Análise do Discurso francesa. Destacamos a "participação de comunhão" estabelecida por Maingueneau (2008, p.106): "trata-se de participações de locutor coletivo, que não privilegiam a fronteira da comunidade com o exterior, mas sim a fusão entre os membros do grupo". Ressaltamos que, devido à fundamentação teórica desta tese ter por base a teoria semiótica, tomaremos com ressalva a noção de "locutor coletivo", substituindo-a pela de actante coletivo. Nessa perspectiva, actante designará uma unidade sintática que, graças ao procedimento de figurativização, será dito coletivo em referência a uma comunidade de fé.

Antes de procedermos à definição da prática de fidelização enquanto uma prática ritualística, convém que estabeleçamos a distinção entre os domínios do sagrado e do profano.

Para tanto, retomamos alguns estabelecimentos da semiótica tensiva, dentre eles, a dimensão da extensidade, segundo a qual o intervalo de referência [concentrado vs. difuso] opera a sintaxe da extensidade mediante triagens e misturas. Zilberberg (2004, p. 90) observa que:

o religioso tem como paradigma básico a tensão entre o sagrado e o profano; essas duas categorias pertencem a estilos axiológicos distintos, que, por sua vez podem ser compreendidos em termos de valências. A prevalência das operações de triagem leva à afirmação e à adoração do sagrado como resultante incomparável e inapreciável das eliminações operadas; a prevalência das operações de mistura leva à afirmação e reconhecimento do profano como resultante aberta e dilatável dos enriquecimentos efetuados.

Subsiste, assim, a recursividade entre as operações de triagem e de mistura entre os domínios do sagrado e do profano:

O sagrado impõe a prevalência da heterogeneidade, da dissociação, de tal forma que esta, portadora daquilo que Cassirer designa pela feliz expressão de 'acento mítico', domina e desqualifica a heterogeneidade. O profano, 
sobretudo em razão dos excessos temporal e espacial que ele se permite dia após dia, deixa prevalecer a homogeneidade e marca toda a distinção como secundária, depois como não-pertinente, por fim como nula (ZILBERBERG, 2004, p. 90).

Vejamos como a prevalência do "acento mítico" (CASSIRER, 2001), expressa por Zilberberg (2004) na oposição entre o sagrado e o profano, e que exploramos no primeiro Capítulo desta tese em referência ao discurso fundador, é discursivizada mediante as práticas de transmissão ritualísticas.

Temos, no discurso fundador, a prevalência das operações de triagem, da heterogeneidade, da dissociação e do acento mítico, que confirmam a presença dos valores de absoluto, voltados para a exclusividade e unicidade e de uma espacialidade circunscritiva, concentrada (ZILBERBERG, 2004, p.90). Retomando a proposição de que a recursividade das operações de mistura implica operações de triagem que lhe são pressupostas, verificamos, nas práticas de fidelização, a transferência desse acento de sentido. Nessa transferência, o sujeito semiótico procura misturar triagens, visando a um valor de universo (ZILBERBERG, 2006, p. 102).

A fidelização religiosa como rito é ação programada, da ordem da extensidade e pertence ao eixo do exercício. O religioso está para a triagem, tal como o profano está para a mistura. A transmissão ritualística seria, portanto, mais intensa em relação ao profano e mais extensa em relação ao discurso fundador. Notamos, assim, a prevalência de operações de triagem na transmissão ritualística intrapares, domínio da comunidade daqueles que partilham da mesma fé. Nela observamos uma espacialidade extensiva, da ordem da difusão.

Vejamos como se configura a fidelização religiosa enquanto ação programada, mediante o gráfico a seguir ${ }^{24}$.

\footnotetext{
${ }^{24}$ A fim de dispor de uma metalinguagem operatória e adequada, Zilberberg (2007, p. 17-18) admite que "o modo de eficiência designe a maneira pela qual uma grandeza se instala num campo de presença. Se esse processo for efetuado a pedido, segundo o desejo de um sujeito, nesse caso teremos a modalidade do conseguir. Se a grandeza se instala sem nenhuma espera, denegando ex abrupto as antecipações da razão, os cálculos minuciosos do sujeito, teremos a modalidade do sobrevir. [...] O acontecimento é, portanto, essa grandeza estranha, por assim dizer, extraparadigmática, ou melhor, essa grandeza se manifesta a princípio no plano sintagmático por uma antecipação e, desse mesmo fato, espera sua identidade paradigmática".
} 


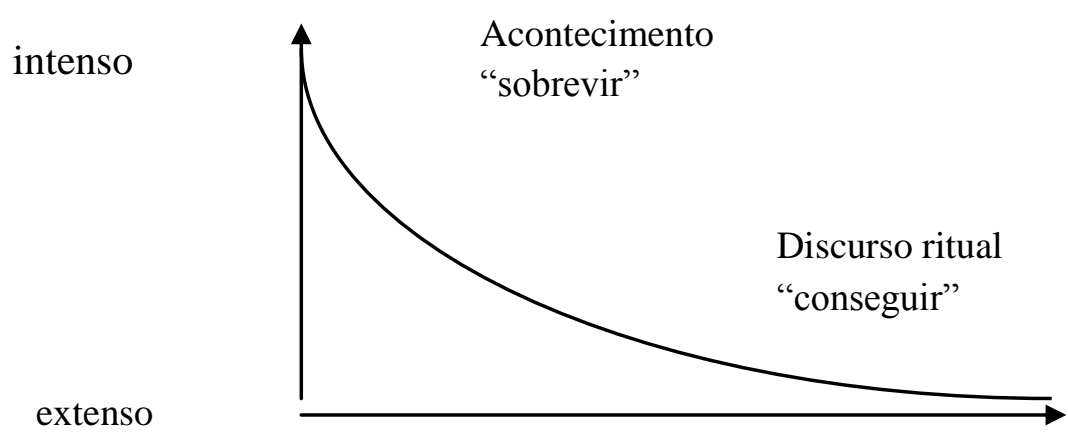

Ação programada

concentração

difusão

Figura 1. Discurso ritual como ação programada.

As práticas de fidelização constituem-se, necessariamente, como ações rituais. O rito faz parte da experiência do ser humano. A ritualidade apresenta-se na vida cotidiana por meio de uma rotina de comportamentos, gestos e ações. O rito é uma forma de ação programada e reiterativa pela qual um sujeito se integra com outros, no caso, com uma estrutura institucionalizada, uma comunidade de fiéis. Associamos a reiteração das ações rituais à noção de ritmo, tal como proposta pela semiótica tensiva (ZILBERBERG, 1979, 1990, 1996, 2001).

A noção de ritmo é de interesse à ampla porção das atividades humanas. Com ela, obtém-se a caracterização distinta dos comportamentos humanos, individuais e coletivos, no que diz respeito a: a) durações e sucessões que regulam esses comportamentos; b) ritmo nas coisas e nos acontecimentos; c) unificação do homem e da natureza ("tempo", "intervalos", “repetições semelhantes") (BENVENISTE, 2005, p. 361-370).

\section{Ritmo}

[Do gr. rhytmós, 'movimento regrado e medido', pelo lat. rhytmu.] 1.Movimento ou ruído que se repete, no tempo, a intervalos regulares, com acentos fortes e fracos;

2. No curso de qualquer processo, variação que ocorre periodicamente de forma regular;

3.Sucessão de movimentos ou situações que, embora não se processem com regularidade absoluta, constituem um conjunto fluente e homogêneo no tempo (FERREIRA, 2004) 
Os textos que materializam a fidelização religiosa trazem uma especificidade rítmica para que se defina a cena enunciativa.

Ratificamos que partimos do princípio de homologia proposto por Hjelmslev (1975, p. 53-64) entre os dois funtivos (expressão e conteúdo) que contraem a função semiótica e das considerações sobre ritmo propostas por Greimas e Courtés (1986), Valéry (1989) e Zilberberg (1979, 1990, 1996, 2001).

Contrariamente a uma acepção de ritmo puramente estética, vista como um arranjo particular do plano da expressão, com apoio em Greimas e Courtés (1986, p. 386), optamos pela noção de ritmo, compreendida como uma forma significante, associada tanto ao plano do conteúdo quanto ao plano da expressão.

A reflexão sobre o ritmo proposta por Zilberberg $(1979,1990,1996,2001)$ é oriunda da proposição de Saussure sobre silabação, mediante a consecução de implosões e de explosões na cadeia fônica, e do modelo hjelmsleviano que lhe deu continuidade. Teremos, portanto, a implosão relacionada ao fechamento e a explosão relacionada à abertura (SAUSSURE, 2004b, p.64).

A noção de ritmo, pouco abordada no âmbito semiótico, exibe seus desenvolvimentos efetuados por meio dos trabalhos de Zilberberg, como dissemos, ao se valer das concepções de Valéry em seus Cahiers. Essa noção é exposta na última seção do primeiro volume dos Cahiers, intitulada "Temps". Vejamos, tal como Válery (1989, p. 1283-1284) a apresenta: "toda lei percebida de uma sucessão é ritmo". Entenderemos o ritmo, portanto, conforme propõe o autor, como manifestação de uma periodicidade, uma lei de sucessão reconhecida enquanto uma percepção mais ou menos acelerada. Essa noção será posta em dependência do andamento como medida de velocidade, o que corresponde, nesse sentido, às modulações de velocidade na percepção que o sujeito tem do mundo discursivizado.

Observamos, dessa maneira, a organização sintagmática, aspectual e rítmica da sequência dos enunciados das práticas de fidelização, tendo como elemento primordial a fidúcia e os simulacros passionais projetados pelo sujeito (actante coletivo) enquanto percepção de mundo. Lembramos ainda que o "ritual supõe um crer específico (todas as práticas têm uma base fiduciária geral), partilhado por todos os participantes, e necessário ao êxito da ação" (FONTANILLE, 2008, p. 50)

O ritual supõe um “exemplo canônico de eficiência sintagmática. Essa 'eficiência está ligada essencialmente à organização sintagmática, aspectual e rítmica da sequência práxica" 
(Idem, p. 50). Mais precisamente, podemos dizer que a prática ritual se assemelha a uma forma de manipulação persuasiva, segundo a qual o enunciatário, além de ser capaz de distinguir o procedimento de que faz parte, também deve estar persuadido a estar comprometido com uma prática específica, circunscritiva, característica de uma determinada comunidade de fé. O próprio caráter "fechado", "concentrado", "circunscritivo" e "recorrente" de uma determinada sequência ritual constitui uma modalização do ato de enunciação, uma figura que tem por objetivo manifestar figurativamente e de uma maneira sensível (perceptível) o seu caráter distintivo (FONTANILLE, 2008, p. 48-49).

Entendemos haver uma função referencial ${ }^{25}$ de natureza retensiva, própria aos discursos de fidelização.

Tendo por base essa função retensiva e circunscritiva, da ordem da triagem e pertencente ao âmbito contratual da fé, estabelecemos uma tipologia que tem por princípio a instituição de três níveis de práticas. Firmamos, como ponto de partida, o enunciatário, considerado sob a acepção de actante coletivo.

Definimos uma gradação da atitude participativa dos fiéis no enunciado das práticas, do mais individual, ao mais coletivo. Delimitamos, assim, três níveis de práticas de fidelização, das quais procedemos à análise de suas subpráticas ${ }^{26}$. Nessa gradação, a eucaristia constitui o ápice da participação em comunidade; a oração, o nível intermediário, e a prática confessional, dada a sua realização individual, o seu contraponto mais tônico [+ individual]. Vejamos:

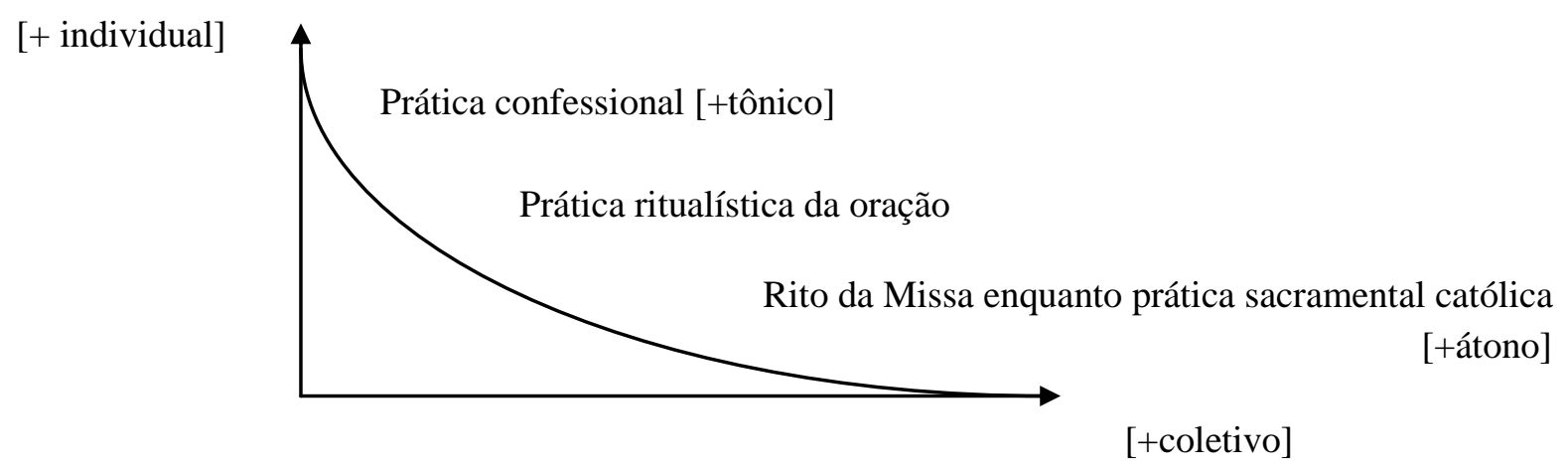

Figura 2. Gradação da atitude participativa dos fiéis.

\footnotetext{
25 "Função referencial é a função cognitiva ou denotativa através da qual o referente da mensagem é considerado como o elemento mais importante" (DUBOIS, 2001, p.512).

${ }^{26}$ Conteúdo veiculado pelo suporte.
} 
Assinalamos o enunciado da prática ritualística católica enquanto experiência da Palavra. Entendemos por Palavra, "Palavra Revelada", discurso fundador bíblico, mas falamos da divulgação da Palavra. Como se caracteriza a experiência da Palavra nas práticas de fidelização religiosa? Como se instituem os mecanismos de vivência sensível da Palavra, enquanto prática de fidelização religiosa? Como podemos depreender o éthos católico das práticas de fidelização, tal como um sujeito com caráter próprio? É o que procuramos demonstrar por meio da análise dos enunciados a seguir.

\section{Análise dos enunciados de fidelização religiosa}

\subsection{Prática ritualística católica da oração}

Para mim, a oração é o impulso do coração, é um simples olhar lançado ao céu, um grito de reconhecimento e amor no meio da provação ou no meio da alegria.

Santa Teresa do Menino Jesus ${ }^{27}$

Procuramos examinar os mecanismos de produção do efeito de sentido afetivo ou passional depreensíveis da prática ritualística católica da oração. Estabelecemos como recorte a seguinte oração devocional cristã: a ladainha de Nossa Senhora, também conhecida como ladainha lauretana. Propomos, mediante a análise do discurso oracional, definir algumas considerações a respeito da estrutura aspectual e, por conseguinte, passional do crer, levando em conta o aspecto fiduciário envolvido nessa prática católica.

Tomamos a oração enquanto um ato de linguagem, uma práxis cognitiva, pragmática e ritual. Dentro da prática ritualística católica, a oração tem por temática o agradecimento ou a súplica dirigida a Deus, a um santo, ou a uma divindade. Ela apresenta, portanto, assuntos os mais variados possíveis, incluindo pedidos de restituição da saúde, obtenção de graças e agradecimentos (COSTA, 2008, p. 145).

A Igreja Católica, embora considere serem todos os momentos indicados para oração, propõe aos fiéis tempos destinados a cadenciar e alimentar a oração contínua: oração da

\footnotetext{
${ }^{27}$ Apud João Paulo II (2000, p.657).
} 
manhã e da tarde, antes e depois das refeições; liturgia das Horas; Eucaristia Dominical; Santo Rosário, Festas do Ano Litúrgico (BENTO XVI, 2005, p.163).

O 'tempo sagrado', que se expressa no calendário de festas e celebrações, ao contrário do tempo profano, recorre constantemente e suas sequências repetem, sempre de novo, a evocação de uma determinada série de acontecimentos destacados (REHFELD, 1988, p. 55).

Retomamos a noção de ritmo na perspectiva de uma semiótica tensiva, como uma lei de sucessão percebida. "A relação entre o tempo, a duração e o ritmo é tributária da relação exclusiva ou participativa, que liga o simultâneo ao sucessivo" (ZILBERBERG, 1990, p. 39).

O ritmo das festas litúrgicas e da prática oracional, através de tempos, repetições e intervalos sucessivos, liga o indivíduo ao grupo, confirmando uma atitude participativa dos fiéis tributários às práticas da mesma fé católica.

\subsubsection{Ladainha de Nossa Senhora (ladainha lauretana): Análise Semiótica}

De acordo com os pesquisadores Basadonna e Santarelli (2000, p. 17), entre os inúmeros textos do gênero ladainha de tema mariano ${ }^{28}$, consolidou-se aquele que esteve em uso desde a primeira metade do século XVI no santuário da Casa Santa de Loreto. Explica-se, assim, a denominação ladainha lauretana. A primeira notícia sobre a prática de cantar-se a ladainha de Nossa Senhora no santuário lauretano data de 10 de dezembro de 1531. Desde então, foram realizadas várias alterações ao texto original, com o acréscimo de novas invocações mediante concessões de caráter universal, além de concessões limitadas a dioceses ou institutos religiosos particulares.

Reproduzimos o texto da tradução latina da ladainha de Nossa Senhora, a ladainha lauretana, aprovada em 9 de junho de 1992 pela Congregação dos Sacramentos e o Culto Divino.

\footnotetext{
${ }^{28}$ O termo "mariano" refere-se ao culto ou a devoção à Virgem Maria, entre os cristãos.
} 
Senhor, tende piedade de nós Cristo, tende piedade de nós Senhor, tende piedade de nós Santa Maria, rogai por nós Santa Mãe de Deus

Santa Virgem das virgens

Mãe de Cristo,

Mãe da Igreja

Mãe da divina graça

Mãe puríssima

Mãe castíssima

Mãe Imaculada

Mãe digna de amor

Mãe admirável

Mãe do bom conselho

Mãe do Criador

Mãe do Salvador

Virgem prudente

Virgem digna de honra

Virgem digna de louvor

Virgem poderosa

Virgem clemente

Virgem fiel

Espelho de perfeição

Sede da sabedoria

Fonte de nossa alegria,

Vaso espiritual

Tabernáculo da eterna glória
Moradia consagrada a Deus

Rosa mística

Torre da santa cidade de David

Fortaleza inexpugnável

Santuário da presença divina

Arca da aliança

Porta do céu

Estrela da manhã

Saúde dos enfermos

Refúgio dos pecadores

Consoladora dos aflitos

Auxílio dos cristãos

Rainha dos anjos,

Rainha dos patriarcas,

Rainha dos profetas,

Rainha dos apóstolos,

Rainha dos mártires,

Rainha dos confessores da fé

Rainha das virgens

Rainha de todos os santos

Rainha concebida sem pecado

Rainha assunta ao céu

Rainha do rosário,

Rainha da paz,

Cordeiro de Deus que tirais os pecados do mundo, perdoai-nos Senhor

Cordeiro de Deus que tirais os pecados do mundo, ouvi-nos Senhor

Cordeiro de Deus que tirais os pecados do mundo, tende piedade de nós.

(BOSADONNA; SANTARELLI, 2000, p, 17) 
O termo "ladainha", em seu sentido corriqueiro, remete a uma espécie de "falação fastidiosa que está sempre repisando as mesmas idéias; enumeração longa e cansativa; repetição monótona e tediosa de queixas e recriminações; lengalenga" (HOUAISS, 2010). Procede dessa utilização o significado vulgar do termo "ladainha" como uma repetição obsessiva de termos esvaziados de sentido, uma sequência repetitiva de afirmações vocais sem real participação do sujeito.

Longe dessa acepção corriqueira, tomamos o enunciado da ladainha como uma prática semiótica do domínio discursivo religioso ${ }^{29}$. O percurso gerativo do sentido, enquanto simulacro metodológico das abstrações que o leitor faz ao longo da leitura de um texto, nos permitirá compreender os mecanismos de construção do sentido desse gênero devoto e contemplativo.

Gêneros discursivos são práticas ou rotinas comunicativas institucionalizadas, "formas de ação social relativamente estáveis realizadas em textos situados em comunidades de práticas sociais e em domínios discursivos específicos” (MARCUSCHI, 2003, p. 25). Concebemos a ladainha, nesse sentido, como um gênero, uma organização relativamente estável, uma ação prática ritual do domínio religioso católico, caracterizada por um conteúdo temático, estilo e composicionalidade.

A temática da ladainha recobre um conteúdo de grande fervor religioso. Caracterizase como uma "oração ou prece litúrgica usada em rituais religiosos diversos, onde os fiéis, organizados ou não em procissão, entoam uma série de invocações a Deus, a Jesus Cristo, à Virgem e/ou aos santos, louvando-os ou solicitando-lhes graças e ajudas". (COSTA, 2008, p. 124).

A fim de examinar a natureza do material vocabular da ladainha, faz-se necessário analisar a composição da estrutura do enunciado, sua forma composicional, portanto.

No que diz respeito à estrutura composicional, o gênero ladainha se constitui como uma oração de súplica, cuja característica é um elemento repetitivo (ora pro nobis - rogai por nós).

\footnotetext{
${ }^{29}$ Por domínio discursivo, referimo-nos às esferas de atividade humana nas quais os textos circulam: discurso religioso, publicitário, midiático etc. Essa noção também foi desenvolvida por Maingueneau (2008) sob o conceito de cena englobante.
} 
Temos, assim, enunciados organizados em uma série de duas sequências injuntivas e invocativas, ligadas por uma formulação imperativa:

\section{Senhor, tende piedade de nós \\ Cristo, tende piedade de nós \\ Senhor, tende piedade de nós \\ Santa Maria, rogai por nós}

A ladainha poderia ser caracterizada, diferentemente dos textos de função utilitária (que tem por objetivo informar, convencer etc), poderia ser caracterizada pela predominância da função estética, dada pela relevância do plano de expressão (PE), que não serve apenas para veicular um conteúdo, mas para recriá-lo em sua organização. Entretanto, perde-se a estesia. Caracteriza-se o enunciado da ladainha enquanto um sistema semi-simbólico. "Sistema semi-simbólico é aquele que estabelece correlações entre categorias da expressão e categorias do conteúdo situadas em todos os níveis do percurso gerativo do sentido" (FIORIN, 2008, p. 59).

O modo de dispor as palavras no enunciado realça os elementos do plano do conteúdo (PC) do texto. Sintagmas cristalizados vão sendo enumerados em retomadas de unidades paradigmáticas. "Relações paradigmáticas são as relações virtuais existentes entre as diversas unidades da língua que pertencem a uma mesma classe morfossintática ou semântica" (DUBOIS, 2001, p. 453).

Verificamos, no enunciado da ladainha, a gradação da súplica, disposta no paralelismo sintático da expressão "rogai por nós", encadeada em sequências injuntivas de tom laudatório e invocatório. Temos uma espécie de ritmo composional da ladainha, dado enquanto uma gradação ascendente da súplica. Cria-se, mediante uma disposição contemplativa da oração, uma inclinação ao conotado. O texto apresenta uma espécie de sintagma cristalizado e repetitivo, conclamando a interlocutora divinizada à ação, suplicando que ela interceda por ele, fiel, enunciador.

Associamos esses sintagmas cristalizados à noção de fórmula discursiva. Faz-se de grande utilidade a incorporação do conceito de "fórmula" desenvolvida por Krieg-Planque (2010) no âmbito da Análise do Discurso francesa.

Esse conceito apresenta uma enorme tradição de estudos nas ciências humanas, da qual podemos destacar pesquisas a respeito de provérbios, slogans, ditados, entre outros. 
Em seu emprego especializado, o termo fórmula designa uma expressão lexical, mais frequentemente, um sintagma nominal ou uma colocação de caráter neológico $^{30}$, que remete a uma noção, tendo exercido, no plano ideológico, um papel fundador ativo em certa construção histórica. Uma fórmula caracteriza-se pelo seu uso maciço e repetitivo, sua circulação em um espaço público em uma conjuntura dada (CHARAUDEAU; MAINGUENEAU, 2004, p. 244)

De acordo com Krieg-Planque (2010), a noção de fórmula apresenta as seguintes propriedades: caráter cristalizado; inscrição em uma dimensão discursiva; função de referente social de uma dada formação discursiva.

A invocação "Santa Maria, rogai por nós" configura, portanto, uma fórmula discursiva, seja pela sua realização estrutural como uma sequência injuntiva cristalizada, seja por sua inscrição no domínio discursivo religioso. Ao estabelecermos a materialidade linguística da ladainha sob uma forma relativamente estável, já projetamos a inserção no discurso. A noção de fórmula, outrossim, não se inscreve dentro do âmbito linguístico, mas discursivo. Essa dimensão discursiva refere-se à utilização da fórmula por uma determinada comunidade discursiva que partilha do domínio religioso ritual católico. E, assim, dada a produtividade da concepção de fórmula discursiva, incorporamo-la ao âmbito da teoria semiótica.

A estrutura segue a utilização inicial do vocativo "Senhor", "Cristo", para evoluir na direção de "Santa Maria", inserida em uma longa lista enumerativa com a repetição da súplica "rogai por nós" a cada invocação. Cada uma das invocações realizadas constitui uma jaculatória.

A jaculatória é um gênero textual que se caracteriza por um conteúdo de grande fervor religioso, estilo laudatório e invocatório (duas sequências injuntivas ligadas na sua formulação imperativa), composição curta com poucos enunciados, voltada para a obtenção de graças ou perdão, a depender da circunstância (MARCUSCHI, 2003, p.24).

\footnotetext{
30 Por neologia, entendemos "o processo contínuo de formação de novas unidades lexicais (palavras ou combinações de uma língua” (CHARAUDEAU; MAINGUENEAU, 2004, p. 346).
} 
Ainda como critério de enumeração, o enunciado apresenta uma série de atributos, um conjunto de qualificações atribuídas a Nossa Senhora. Dentre elas, destacamos: "Espelho de perfeição"; "Sede da sabedoria"; "Fonte de nossa alegria"; "Vaso espiritual" etc.

O tempo, na ladainha, converte-se em uma vivência sensível pautada pela aceleração e pela predominância de valores emissivos ${ }^{31}$ dados pela retomada do mesmo tópico: as qualificações laudatórias a Nossa Senhora. As articulações composicionais exprimem uma intensificação, na qual a inclinação estética da ladainha remete à posição de um corpo, ativo, paradoxalmente contemplativo, do fiel instaurado no enunciado.

Temos, assim, um estilo tensivo (ZILBERBERG, 2006) caracterizado pela velocidade e duração próprias a um devir. Uma espécie de esquematismo tensivo ascendente, responsável pela projeção no campo de presença de cada vez mais unidades concentradas na célula única, a fim de que se tenha o restabelecimento da relação juntiva do sujeito, intermediada pelo pedido de súplica. Esse conjunto de configurações aspectuais apresenta grande ligação com a Retórica, na medida em que a argumentação também se situa como uma prática discursiva (FONTANILLE, 2008, p. 38).

Dentre as figuras retóricas que têm por objetivo aumentar o efeito de sentido de presença, destacamos a utilização da acumulação como figura de repetição. A acumulação é uma figura de pensamento, na qual predomina a sequência e emparelhamento de termos linguísticos pertencentes à mesma esfera conceitual, a que associamos o conceito de isotopia.

$\mathrm{O}$ enunciado da ladainha apresenta diversas isotopias figurativas que correspondem a uma mesma isotopia temática (tema da intercessão e proteção divina).

Espelho de perfeição

Sede da sabedoria

Fonte de nossa alegria,

Vaso espiritual

Tabernáculo da eterna glória

Moradia consagrada a Deus

Rosa mística

Torre da santa cidade de David

Fortaleza inexpugnável

Santuário da presença divina

Arca da aliança

Porta do céu

Estrela da manhã

\footnotetext{
${ }^{31}$ Aos valores emissivos, também denominados continuativos, associamos a noção de programa, a parada da parada. Ao fazer remissivo, associamos o antiprograma, a parada (ZILBERBERG, 2006, p. 133).
} 
Saúde dos enfermos

Refúgio dos pecadores

Consoladora dos aflitos

Auxílio dos cristãos

Vejamos como se consolida a figurativização de cada uma das séries de invocações:

$1^{a}$. Série de invocações: figurativização da temática de Jesus Cristo e da Santíssima Trindade;

Senhor, tende piedade de nós

Cristo, tende piedade de nós

Senhor, tende piedade de nós

$2^{a}$. Série de invocações: figurativização da temática da maternidade de Maria;

Mãe de Cristo,

Mãe da Igreja

Mãe da divina graça

Mãe puríssima

Mãe castíssima

Mãe Imaculada

Mãe digna de amor

Mãe admirável

Mãe do bom conselho

Mãe do Criador

Mãe do Salvador

$3^{a}$. Série de invocações: figurativização da temática da virgindade de Maria;

Virgem prudente

Virgem digna de honra

Virgem digna de louvor

Virgem poderosa

Virgem clemente

Virgem fiel

$4^{a}$. Série de invocações: (figuras simbólicas) - Símbolos de Maria que evidenciam sua virtude e papel como co-redentora da humanidade.

Espelho de perfeição

Sede da sabedoria

Fonte de nossa alegria,

Vaso espiritual

Tabernáculo da eterna glória 
Moradia consagrada a Deus

Rosa mística

Torre da santa cidade de David

$5^{a}$ Série de invocações: figurativização de Maria como Rainha.

Rainha dos anjos,

Rainha dos patriarcas,

Rainha dos profetas,

Rainha dos apóstolos,

Rainha dos mártires,

Rainha dos confessores da fé

Rainha das virgens

Rainha de todos os santos

Rainha concebida sem pecado

Rainha assunta ao céu

Rainha do rosário,

Rainha da paz,

6a. Série de invocações: figurativização da intercessão de Maria junto a Cristo remissão dos pecados

Cordeiro de Deus que tirais os pecados

do mundo, perdoai-nos Senhor

Cordeiro de Deus que tirais os pecados do

mundo, ouvi-nos Senhor.

Cordeiro de Deus que tirais os pecados do

Mundo, tende piedade de nós.

Essa forma de enumeração (enumeratio), apresentada pelo autor, refere-se às listas panegíricas $^{32}$ ou encomiásticas ${ }^{33}$, às quais pertence o gênero ladainha.

Desde a antiguidade, a retórica sempre apreciou as listas ritmicamente escandidas e escandíveis, mas não importava tanto mencionar quantidades inexauríveis quanto atribuir propriedades a alguma coisa, de modo redundante, por amor da reiteração (ECO, 2010, p. 133).

A repetição das sequências invocativas reflete o andamento acelerado da percepção que o fiel tem do mundo, diante de cada súplica dirigida a Nossa Senhora. Associamos essa percepção a uma atitude contemplativa do sujeito diante da Virgem e só dela, o que poderia

32 "Elogio solene; [...] que louva, que contém louvor; elogioso, laudatório" (HOUAISS, 2010).

33 "Fala ou discurso em louvor de alguém; elogio, gabo [...] hino religioso de louvor" (HOUAISS, 2010). 
gerar uma espécie de catarse. Para que possamos entender mais claramente como se configura o processo catártico, referimo-nos à identificação do sujeito com o objeto de sua fé, a Virgem, discursivizada na ladainha. O sujeito permanece no plano da enunciação enunciada. Temos, assim, a atitude contemplativa que se desdobra na voz presentificada (eu-tu). O sujeito é conduzido por meio de sequências invocativas e expressões injuntivas que giram em torno do mesmo tema (evocação à intermediação de Maria). Por meio desse ângulo, contempla-se a pessoa, a fé e a crença na intermediação divina realizada pela figura de Nossa Senhora. "A ladainha faz a pessoa penetrar pouco a pouco na realidade a que se alude: se se trata de pessoa, entra-se vagarosamente em seu mistério" (BOSADONNA; SANTARELLI, 2000, p. $55)$.

O estilo, segundo Bakhtin (2003), refere-se às marcas linguísticas exigidas por um determinado gênero e que o caracterizam. De acordo com Discini (2004b), o estilo diz respeito ao éthos, seja do autor, seja do gênero, o que ultrapassa o que Bakhtin propõe. O estilo conforme o qual a ladainha se caracteriza é marcado pelo ritmo repetitivo com que se desdobram cada uma das invocações, dispostas em frases breves, atributos lapidares, adjetivos e locuções. Temos aí um éthos devoto, comtemplativo e de estilo laudatório e invocatório.

Observamos a organização aspectual e rítmica da sequência de invocações oracionais, tendo como elemento primordial a fidúcia e os simulacros passionais projetados pelo sujeito enquanto percepção de mundo. Lembramos ainda que o "ritual supõe um crer específico (todas as práticas têm uma base fiduciária geral), partilhado por todos os participantes, e necessário ao êxito da ação (FONTANILLE, 2008, p. 50)".

Por contrato fiduciário, associamos um fazer persuasivo por parte do destinador e, em contrapartida, a esperada adesão do enunciatário. Trata-se da construção de simulacros, imagens intersubjetivas projetadas no enunciado, e que aludem à confiança no outro, ou a confiança em si mesmo (GREIMAS; COURTÉS, 2008, p. 208).

Verificamos, no enunciado da ladainha, a formulação de uma relação fiduciária (GREIMAS, 1983, p. 229) a que demominamos "crer", entre o actante sujeito (fiel) e a imagem de Maria como intermediadora e intercessora que este constrói para si. Além da expectativa fiduciária desse actante sujeito, fiel, a um /querer-estar reunido/, e, portanto, restituído aos valores católicos, com os quais se teria desvinculado pela prática do pecado, notamos, principalmente, a confiança na obrigação conjuntiva do sujeito do fazer (Nossa Senhora). 
O programa narrativo de base que rege este discurso pode ser descrito como se segue:

$\mathrm{S} 1$ querer $[\mathrm{S} 2 \rightarrow(\mathrm{S} 1 \cap \mathrm{Ov})]=$ querer estar reunido, restituído aos valores católicos;

$\mathrm{S} 1$ crer $[\mathrm{S} 2$ dever $\rightarrow(\mathrm{S} 1 \cap \mathrm{Ov})]=$ crença na intermediação e intercessão de Nossa Senhora.

Percebemos, no enunciado da ladainha, um contrato fiduciário estabelecido pelos actantes destinador e destinatário (S1 e S2). A crença é uma sobremodalização, o que confirma a intercessão de Nossa Senhora e consequente restituição do fluxo fórico. Ressaltamos, assim, a crença dos fiéis na proteção e intercessão da Virgem Maria e de todos os Santos junto de Deus.

Configura-se a expectativa fiduciária segundo a qual o actante-sujeito julga haver um destinador transcendente, dotado das modalidades do poder/dever atender a súplica realizada: a Virgem, Mãe de Deus, mistura-se ao próprio Deus.

$\mathrm{O}$ culto à figura de Nossa Senhora como intercessora e mediadora entre homens e Deus é de importância salutar para a Igreja.

\begin{abstract}
A maternidade de Maria, na economia da graça, perdura sem cessar, desde o consentimento que ela prestou fielmente na anunciação e manteve sem vacilar ao pé da cruz, até a consumação final de todos os eleitos. De fato, depois de elevada ao céu, não abandonou esta missão salutar, mas, pela sua múltipla intercessão, continua a obter-nos os dons da salvação eterna. Com seu amor de Mãe, cuida dos irmãos de seu Filho, que ainda peregrinam e se debatem entre perigos e angústias, até que sejam conduzidos à Pátria feliz. Por isso, a Santíssima Virgem é invocada, na Igreja, com os títulos de Advogada, Auxiliadora, Amparo e Medianeira (PAULO BISPO, 2003, p. 126-127).
\end{abstract}

$\mathrm{O}$ enunciado da ladainha se configura pela presença de uma estratégia de manipulação, com a qual o destinador busca instaurar um querer-fazer no destinatário (fiel), para que este entre também em conjunção com a fé do culto à Maria. Fica implicitado um actante, destinador transcendente, Deus, que, por intermédio de Maria, acolhe o fiel, como aquele que tudo pode e sabe.

Temos, portanto, mediante essa prática oracional, a relação entre o sujeito (actante coletivo), a fé (crença), a súplica, a remissão dos pecados e o dogma. 
Denominamos o sujeito inserido no domínio discursivo da prática oracional um actante coletivo, pois este não privilegia a fronteira da comunidade com o exterior, mas sim a fusão interna entre os membros do grupo. Caracteriza-se, desse modo, a participação na comunhão, nessa prática da oração. Ressaltamos o caráter de sistema de participação da oração, cujo domínio consolida a comunidade pertencente a um mesmo tesauro. Por domínio, integramos a memória discursiva ${ }^{34}$ (conhecimento das orações) e a competência comunicativa (saber que orações dizer e diante de qual situação) do sujeito (MAINGUENEAU, 2008, p. 106).

Em se tratando de discurso e lugares sociais, verificamos, no enunciado da ladainha, o predomínio da espacialização dada no eixo da verticatilidade. O olhar da verticalidade constrói o plano espiritual a partir do ponto de vista eufórico, estabelecendo o "alto" como categoria eufórica. Seu olhar constrói-se por meio do "baixo" (disfórico) para o "alto" (eufórico). Delineia-se, assim, a organização da sequência narrativa: eu (actante coletivo) em direção a Cristo nosso Senhor por intermédio de Maria.

O programa de oração, para o qual nos remetemos à eficácia da palavra empregada pela ladainha (FONTANILLE, 2008), é pautado pelo uso de formulações imperativas que determinam a realização de uma determinada "conduta" ritual por parte do sujeito (interlocutor divino - Maria - figura da intercessora).

Acaba por caracterizar-se a manipulação de um destinador, o enunciador, o interlocutor, aquele que diz "eu", ao interlocutário, o "tu”, a Virgem Mãe. Temos aí uma tensão para a conjunção (BLANCO, 2008, p. 57). Inicialmente, o sujeito patêmico (pecador, instaurado no enunciado) configura uma espécie de "ressentir" "do estado limite e espera do retorno da fusão". Essa espera repousa sobre a fidúcia. Observamos a dimensão passional do sujeito pautada pela expectativa de retorno aos valores com os quais este se teria desvinculado, expectativa esta que designamos, em semiótica, como protensividade fórica (GREIMAS; FONTANILLE, 1993, p. 30). Caso o destinatário (Nossa Senhora) faça o que pedimos, concretizar-se-á a expectativa fiduciária do sujeito e a tensão será atenuada. Se o simulacro aspectualiza o sujeito, confirmando nele um modo de ser no mundo,

\footnotetext{
34 "Uma formação discursiva é tomada em uma dupla memória [...]. Ela constrói para si uma memória externa colocando-se na filiação das formações discursivas anteriores. Ao longo do tempo ela cria também uma memória interna (com os enunciados produzidos antes, no interior da mesma formação discursiva). O discurso se apóia, então, em uma Tradição, mas cria pouco a pouco a sua própria Tradição. Aqui a memória não é psicológica, ela mantém-se em unidade com o modo de existência de uma formação discursiva: cada uma tem uma maneira própria de administrar essa memória" (MAINGUENEAU, 1998, p. 96-97).
} 
sobremodalizando a sua competência modal, fazendo-o querer ser de certo modo, no caso, conjunto aos valores católicos, a construção desse sujeito em sua proprioceptividade ${ }^{35}$ confirma o imaginário modal do sujeito e, por conseguinte, uma motivação orientada para uma imagem-fim (reintegração) projetando sua configuração passional (GREIMAS; COURTÉS, 1993). Assinalamos, assim, a figura de um sujeito divino (Deus, Espirito Santo) atingível apenas mediante a figura de Maria, tida enquanto mediadora (intercessora) capaz de restabelecer o fluxo fórico do fiel-enunciador, reintegrando-o a tais valores: "Rogai por nós, santa Mãe de Deus. Para que sejamos dignos das promessas de Cristo”

Remetamos aos efeitos de passionalização. Segundo a direcionalidade tensiva orientada para a concentração espacial e aceleração do andamento, o que pode ser verificado no enunciado por meio da justaposição da série de sequências injuntivas de súplicas em estilo laudatório e invocatório a partir de uma percepção ascendente em tonicidade. Podemos delinear o estilo do enunciado da experiência da palavra (prática católica da oração) por intermédio de uma direção ascendente.

\subsection{O Rito da Missa enquanto Prática Sacramental Católica}

\subsubsection{Folheto Litúrgico - Semanário Litúrgico-Catequético: Análise Semiótica}

Na liturgia da missa, exprimimos nossa fé na presença real de Cristo sob as espécies do pão e do vinho, entre outras coisas, dobrando os joelhos, ou inclinando-nos profundamente em sinal de adoração ao senhor.

João Paulo II $^{36}$

Procuramos examinar os mecanismos de produção do efeito de sentido afetivo ou passional depreensível do rito da missa enquanto prática ritualística sacramental católica.

Dentre os enunciados pertencentes à prática de fidelização própria ao domínio religioso católico, estabelecemos como recorte analítico o folheto litúrgico (suporte do rito eucarístico), também denominado semanário litúrgico catequético. Trata-se aqui, mais do que o exame do enunciado em si, de sua compreensão enquanto processo, interação e prática

\footnotetext{
${ }^{35}$ Entendemos por proprioceptividade o termo complexo da categoria exteroceptividade/interoceptividade. Esse termo tem por objetivo "classificar o conjunto das categorias sêmicas que denota o semantismo resultante da percepção que o homem possui de seu próprio corpo" (GREIMAS; COURTÉS, 2008, p. 393).

${ }^{36}$ João Paulo II (2000, p. 380).
} 
social (LANDOWSKI, 2004, p. 16). Temos, ainda, como objeto de estudo a noção de práticas semióticas empreendida por Fontanille (2008), bem como os desenvolvimentos de Blanco (2008). Ampliaremos as proposições de Blanco, que procurou tratar o rito da missa enquanto uma prática ritual. Para isso, realizamos a inclusão do folheto litúrgico, subprática manifestada enquanto objeto-suporte do rito eucarístico ${ }^{37}$.

Dentre os folhetos litúrgicos em circulação no domínio religioso católico, estabelecemos como recorte o folheto O Povo de Deus em São Paulo, publicação da Mitra Arquidiocesana de São Paulo. A Arquidiocese de São Paulo constitui uma circunscrição da Igreja Católica no Brasil, Sé Metropolitana da Província Eclesiástica de São Paulo, pertence ao Conselho Episcopal Regional Sul I da Conferência Nacional dos Bispos do Brasil (CNBB).

O folheto litúrgico, ao compor-se como um enunciado de fidelização religiosa, configura um gênero textual pertencente à esfera de circulação do discurso religioso e apresenta como elemento constitutivo de sua temática a reatualização do sacrifício eucarístico. O folheto litúrgico caracteriza-se, portanto, mediante a sua utilização como subsídio para a participação dos fiéis à Santa Missa. Esse folheto tem ainda a propriedade de promover a unidade dos católicos nas celebrações dominicais da Arquidiocese e de outras paróquias que o assinam. O Povo de Deus em São Paulo assinala-se como um canal de comunicação dos principais eventos da Igreja de São Paulo. Contemporaneamente, o folheto O Povo de Deus em São Paulo apresenta sua difusão por meio de assinaturas realizadas pelas paróquias, totalizando cerca de 70 mil exemplares por domingo. Levando em conta que o suporte também é determinante para a depreensão do sentido do texto, reproduzimos o enunciado do folheto no volume II, referente aos anexos desta tese, sob a designação "T7"38.

Ao pertencer à esfera de atividades institucionalizadas da prática religiosa católica, o folheto litúrgico configura-se como um instrumento autorizado a ser usado como subsídio às ações litúrgicas da Santa Missa.

Contemplemos, inicialmente, a composição diagramática do enunciado do folheto (Cf. T7, Vol II, Anexos). Ao observar o enunciado, verificamos que ele se constitui por uma composição diagramática pautada pelo efeito de sentido de simplicidade, em correspondência

\footnotetext{
${ }^{37} \mathrm{O}$ nível do objeto-suporte, em seu movimento de integração às práticas, é um caso exemplar do tratamento das propriedades materiais. Enquanto corpo material, na verdade, o objeto entra nas práticas e os usos dessas práticas são em si mesmos "enunciações" do objeto. Sob esse aspecto, o objeto em si só pode conter traços desses usos [...], ou seja, "vestígios enunciativos" (FONTANILLE, 2008, p. 25).

${ }^{38}$ As indicações "T" seguidas do referido número correspondem à numeração dos textos em análise e que se encontram no volume II, anexos.
} 
aos ideais didáticos de brevidade e clareza propostos pelo plano do conteúdo (PC). A própria materialidade do enunciado, determinado pelo tipo de papel (papel de jornal ${ }^{39}$ ), é característica da publicação $^{40}$ e de sua difusão como subprática manifestada no objeto-suporte do rito eucarístico.

A noção de "modo de difusão" se emparelha à de "modo de consumo" (MAINGUENEAU, 2005a, p. 141), que corresponde ao modo como esse discurso é lido, consumido e manipulado.

No plano de expressão (PE), notamos o título-síntese do enunciado disposto no alto, em letra de tamanho maior, em caixa alta e de cromatismo preto sob um fundo azul. Esse cromatismo perpassa toda a composição do folheto litúrgico, que é composto dessas mesmas cores “preto e azul”, presentes na própria segmentação do enunciado em partes.

Tomamos, como base, o folheto O Povo de Deus em São Paulo, de 16 de maio de 2010.

No que concerne à coerção genérica, a sua forma composicional, portanto, ele apresenta a seguinte estrutura: a) divisão em cinco atos e algumas cenas intermediárias, em referência ao rito eucarístico; b) ancoragem espacial e temporal representada sob a forma de cabeçalho; c) presença de uma ilustração didática.

Examinemos, inicialmente, a disposição desse gênero em cinco grandes atos e algumas cenas intermediárias. Essa segmentação dada no plano textual se estabelece em correspondência ao rito eucarístico (subprática) do qual o enunciado do folheto serve como manifestação enquanto objeto-suporte:

a) Ritos iniciais
1. ${ }^{41}$ Acolhida
2. Saudação
3. Ato Penitencial

\footnotetext{
39 "Papel de qualidade um pouco inferior à dos demais papéis de impressão, com superfície áspera e pouco encolado, geralmente usado na impressão de jornais, devido a seu baixo custo, rápida secagem e outras conveniências de produção" (RABAÇA; BARBOSA, 1987, p. 444).

${ }^{40}$ Caracteriza-se o folheto como uma "publicação não-periódica, com número limitado de páginas (mínimo de 5, máximo de 48, excluídas as capas”(RABAÇA; BARBOSA, 1987, p. 274)

${ }^{41}$ A numeração que antecede cada uma das cenas intermediárias refere-se à numeração original, tal como cada uma dessas seções aparece no folheto em análise (Cf. T7, Vol, II, Anexos).
} 
4. Hino de Louvor

5. Oração

b) Liturgia da Palavra

6. Primeira Leitura (Antigo Testamento)

7. Salmo Responsorial

8. Segunda Leitura (Novo Testamento)

9. Aclamação ao Evangelho

10. Evangelho (Homilia)

11. Profissão de fé

12. Oração dos fiéis

c) Liturgia Eucarística

13. Apresentação das oferendas

14. Oração sobre as oferendas

15. Oração eucarística

d) Rito da Comunhão

16. Pai Nosso

17. Canto de comunhão

18. Oração após a comunhão

19. Oração ao nosso patrono (opcional)

e) Ritos finais

20. Bênção e despedida

21. Canto Final

Comunicados da Arquidiocese

Leituras da Semana 
A ancoragem espacial e temporal é representada no enunciado sob a forma de cabeçalho: "São Paulo, 16 de maio de 2010. Ano 34. Lt 4. No. 33. C".

A referência a São Paulo espacializa o enunciado enquanto uma publicação a ser utilizada pelas paróquias pertencentes à Arquidiocese de São Paulo. O ano “33” refere-se aos anos de edição do folheto.

As letras "A", "B" e "C" correspondem ao modo como foram distribuídos os evangelhos dominicais. Por meio delas, temos a representação da leitura do evangelho correspondente a um determinado ano. Verificamos as leituras do evangelho de Mateus (Ano A), Marcos (Ano B) e, no caso, Lucas (Ano C).

A cada ano, os cristãos revivem as etapas consideradas mais importantes da vida de nosso Senhor: nascimento, morte, ressurreição, ascensão e envio do Espírito Santo. Assim como no ano civil, somos orientados pelas estações do ano e festas cívicas, o Ano Litúrgico ${ }^{42}$ orienta os fiéis em sua caminhada de fé, marcada pelos momentos fortes da vida do Senhor (BORTOLINI, 2006, p.7).

O Ano Litúrgico apresenta-se organizado em etapas. $O$ primeiro modo de compreender a sua organização é caracterizá-lo por meio de ciclos. “Ciclo é um período em que ocorrem fatos históricos importantes a partir de um acontecimento, seguindo uma determinada evolução" (BORTOLINI, 2006, p.8). O primeiro fato histórico considerado mais importante da vida de Cristo é o seu nascimento, o Natal. Temos, assim, o estabelecimento do primeiro ciclo, o Ciclo do Natal. Esse fato está ligado a outros, que o antecedem e o seguem e que compõem juntamente com o nascimento de Cristo o ciclo do Natal. São eles: Advento, Natal, Sagrada Família, festa da Mãe de Deus, Epifania e Batismo do Senhor.

A Páscoa caracteriza-se como o segundo fato histórico mais importante. Fazem parte do Ciclo da Páscoa: Quaresma, Semana Santa, Tríduo Pascal, Páscoa, domingos da Páscoa (Ascensão) e Pentecostes. O terceiro e mais longo período do ano, com 34 domingos, recebe a designação de Tempo Comum. O Ano Litúrgico se inicia no primeiro domingo do Advento e termina no $34^{\circ}$ domingo do Tempo Comum.

\footnotetext{
${ }^{42} \mathrm{O}$ ano litúrgico é o desdobramento de diversos aspectos do único mistério pascal. Isto vale muito particularmente para o ciclo das festas em torno do mistério da encarnação (Anunciação, Natal, Epifania) que comemoram o começo de nossa salvação e nos comunicam as primícias do Mistério da Páscoa (JOÃO PAULO II, 2000, p. 330).
} 
O tempo litúrgico em que o enunciado do folheto se situa é o Ciclo da Páscoa, em remissão à “Ascensão do Senhor”, título do folheto.

Vejamos o que representa a Ascensão, dentro do domínio religioso católico:

\begin{abstract}
A Ressurreição de Jesus é a verdade culminante da nossa fé em Cristo e representa, com a Cruz, uma parte essencial do Mistério Pascal. [...] Depois de quarenta dias, período em que se mostrou aos Apóstolos sob os traços de uma humanidade comum que escondiam a sua glória de Ressucitado, Cristo sobe aos céus e se senta à direita do Pai. Ele é o Senhor que reina agora com a sua humanidade na glória eterna do Filho de Deus e intercede incessantemente a nosso favor junto ao Pai. Envia-nos o seu Espírito e nos dá a esperança de estar com ele um dia, tendo-nos preparado um lugar (BENTO XVI, 2005, p. 53-55).
\end{abstract}

O enunciado considerado supõe que a depreensão do sentido seja dada por meio das relações sincréticas entre os dois sistemas (verbal e visual) de que se compõe o folheto litúrgico (FLOCH, 1985). Assim, como estamos diante de um texto sincrético, devemos considerar a articulação entre as diferentes linguagens, verbais e visuais, dadas por meio da utilização da ilustração didática, tudo voltado para uma unidade de sentido.

A ilustração didática, um sistema semiótico plástico, ao operar a homologia com o sistema semiótico verbal do folheto litúrgico, confirma-o como um enunciado sincrético.

Observamos, então, a presença de um sincretismo entre imagem e palavra. A estratégia enunciativa que sincretiza as diferentes linguagens de manifestação, numa totalidade de sentido, exerce-se de modo contratual.

No que concerne à coerção das imagens, percebemos que a ilustração didática, tal como nas Bíblias ilustradas, apresenta uma função pedagógica. As imagens têm como objetivo tornar esse discurso mais palatável, pois a coerção se dá pelo verbal, ao operacionalizar a colocação de categorias da crença a todo o momento.

No que diz respeito à imagem presente no enunciado do folheto, notamos a figurativização da temática da Ascensão de Cristo, por meio do cordeiro de Deus.

A Palavra Revelada é instituída como fonte primeira desse discurso, que tem por objetivo a realização do rito de atualização do sacrifício de Jesus na cruz.

O enunciado de folheto caracteriza-se, portanto, como um texto narrativo pautado pela progressão temporal e reduplicação mítica do discurso fundador, no caso, o relato bíblico de I Coríntios (I Coríntios 11, 23-26): 
A "Ceia do Senhor" - [... ${ }^{23}$ Com efeito, eu mesmo recebi do Senhor o que vos transmiti: na noite em que foi entregue, o Senhor tomou o pão ${ }^{24}$ e, depois de dar graças, partiu-o e disse: "Isto é o meu corpo, que é para vós; fazei isto em memória de mim". ${ }^{25}$ Do mesmo modo, após a ceia, também tomou o cálice, dizendo: "Este cálice é a nova Aliança em meu sangue; todas as vezes que dele beberdes, fazei-o em memória de mim. ${ }^{26}$ Todas as vezes, pois, que comeis desse pão e bebeis desse cálice, anunciais a morte do Senhor até que ele venha.

A referência ao discurso fundador confirma o caráter ritual da Santa Missa enquanto uma encenação. Temos, assim, por meio do enunciado do folheto, a construção de uma cenografia sacramental, na qual são colocadas em cena ações, gestos, palavras e acontecimentos para fazer presente um acontecimento destacado, no caso, a remissão à Santa Ceia, na condição de discurso fundador. O símbolo de comunhão eclesial estabelecido por Jesus com os seus discípulos na Última Ceia é recebido e ritualizado pela Igreja. A celebração eucarística constitui, portanto, a perpetuação eclesial dos símbolos instituídos por Jesus.

Verificamos, desse modo, uma tradição de continuidade espacial e temporal do rito da celebração eucarística, que teve seu início com a Última Ceia de Jesus, celebrada com os apóstolos na véspera de sua Paixão e Morte. Segue-se, a cada missa, uma cadeia ininterrupta de enunciações dessa prática ritual.

A última santa ceia de Jesus antes de sua paixão deu continuidade à sua prática anterior de refeições, pelo fato de que também lá a ceia, pela participação de Jesus, já se tornou antecipação, em forma de sinal, do senhorio vindouro de Deus (PANNENBERG, 2009, p. 396).

A memória figurativa da Última Ceia transposta ao corpo textual e discursivo do rito eucarístico, ao supor a vigência de uma tradição, adota um protocolo, sendo perpetuada sem interrupção pela Igreja. Entendemos por vigência de uma tradição a continuidade temporal e espacial da realização desse rito, uma cadeia temporal ininterrupta de enunciações, de práticas rituais. Configura-se, diante disso, o rito da missa enquanto uma prática significante, pertencente, segundo os princípios da semiótica tensiva ao domínio da extensidade.

O ritual eucarístico acompanha um exemplo canônico de eficiência sintagmática. Compreendemos por eficiência sintagmática a organização sintagmática, aspectual e rítimica da sequência práxica (FONTANILLE, 2008, p. 48). Sendo assim, a eficiência do ritual da missa deriva de estrita aplicação de um esquema e de um percurso gerativo fixo, tal como procuramos demonstrar a seguir. 


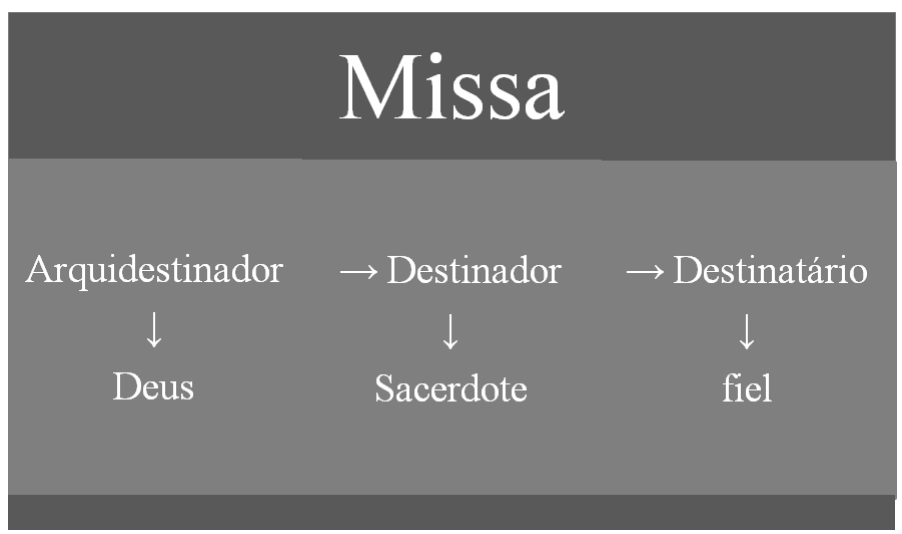

Figura 3. Esquema do ritual da Santa missa

Tomemos, inicialmente, o seguinte mandamento de Jesus, discursivizado no enunciado do folheto como uma fórmula ritual: "Fazei isto em memória de mim".

Ressaltamos o caráter injuntivo dessa fórmula discursiva que tem por objetivo manipular os destinatários (apóstolos e sucessores) a prosseguir com a tradição da performance de ações práticas referentes à repetição dos gestos e palavras realizados por Jesus Cristo na Última Ceia. Essa manipulação visa, portanto, à celebração litúrgica pelos apóstolos e seus sucessores (mediadores - sacerdotes) do memorial da vida, morte, ressurreição de Cristo e intercessão dele junto ao Pai, em benefício dos fiéis. Remetemos à noção de actante coletivo em referência à comunidade de fiéis, pois essa prática ritual privilegia a atitude participativa dos fiéis na eucaristia, a fusão entre os membros do grupo. Temos, então, a fidelização religiosa dada por meio da experiência da Palavra.

Além de ser obra de Cristo, a liturgia é também uma ação da sua Igreja. Ela realiza e manifesta a Igreja como sinal visível de comunhão entre Deus e os homens por meio de Cristo. Empenha os fiéis na vida nova da comunidade. Implica uma ação "consciente, ativa e frutuosa" de todos (PAULO II, 2000, p. 302).

No que concerne ao (PN), "sintagma elementar da sintaxe narrativa", (BARROS, 2002, p. 31), observamos a transformação principal operacionalizada por esse discurso como a ação de um sujeito sobre outro, para que este último possa manter-se em conjunção com o objeto valor "graça divina".

Assim, o programa de base que rege esse discurso pode ser descrito como segue: 
PN de base: $S_{1} \rightarrow S_{2} \cap O_{v}$

$\mathrm{S}_{1}=$ ministro sacramental $\quad \mathrm{S}_{2}=$ cristão $\quad \mathrm{O}_{\mathrm{v}}=$ graça divina

Figura 4. Programa narrativo de base

Observamos que o PN de base que rege esse enunciado apresenta o Sujeito $S_{1}$ fazendo com que $\mathrm{S}_{2}$ permaneça em conjunção com o $\mathrm{O}_{\mathrm{v}}$ "graça divina", cujo investimento semântico e atribuição já teriam sido efetuados num PN de base, subentendido, que remonta à aquisição dos sacramentos de iniciação cristã do Batismo e Crisma.

Após a saudação inicial que, como todas as práticas rituais, começa por meio da fórmula ritual "Em nome do Pai, do Filho e do Espírito Santo. Amém", há a abertura do programa modal que visa à participação do fiel (actante coletivo) no rito eucarístico. Dispõese, assim, o programa modal que tem por objetivo preparar o actante sujeito coletivo a participar dos sagrados mistérios da redenção divina.

Logo após a saudação inicial, temos o ato penitencial, caracterizado pela presença de um programa modal de baixa intensidade, que tem por objetivo realizar a conversão do pecador, para que este entre novamente em um programa conjuntivo com o objeto-valor "graça divina". Temos como contrapartida o contraprograma dominante, o contraprograma disjuntivo do pecado promovido pelo maligno, enquanto destinador do mal. Assinalamos, assim, a disposição no enunciado de ambos os programas em favor do sujeito pecador disposto a continuar a prática ritual.

O PN estabelecido pelo destinador-manipulador para que o sujeito permaneça conjunto com tais valores corresponde ao fazer emissivo, que também poderíamos denominar continuativo. Nele privilegiamos a dominância da temporalidade emissiva (parada da parada), responsável pelas experiências conjuntivas pautadas duração alongada. O antiprograma, realizado de modo implícito pelo antidestinador, demônio e más inclinações, corresponde ao fazer remissivo, à parada. Ao antiprograma remetemos o conceito de surpresa, encarregado da ruptura da relação contratual entre destinador e destinatário e da interrupção do fluxo fórico.

Notamos, ao longo do texto, a presença do destinador-manipulador tentando fazer com que o sujeito não pare, que ele siga o curso de restabelecimento da união original. Desse 
modo, o destinador-manipulador tenta assegurar a diretividade da direção estabelecida pelo âmbito contratual da fé e, para isso, faz uso de modulações de velocidade.

Toda ruptura pressupõe como coeficiente tensivo a alta velocidade, que poderia ocasionar a cisão do próprio sujeito e dos laços que o ligam ao sistema de valores considerado. Assim, para evitar a fratura da identidade entre sujeito e objeto e, consequentemente, a fratura do sistema de valores representado pela ideologia religiosa católica, o enunciador procede ao estabelecimento do prolongamento da relação conjuntiva, o que remete a uma experiência conjuntiva pautada pelo andamento desacelerado.

A desaceleração faz a duração durar de modo a dar tempo ao tempo. Por mais desconfortável que esteja a situação do sujeito, se este puder graduar seu tempo de acordo com certa programação, estabelecendo uma ordem de espera, é provável que obtenha as condições mínimas de segurança para conduzir seus passos seguintes. (TATIT, 2001, p. 117)

O domínio da religião não deseja que o objeto seja partido, para isso o crer faz uso do fazer emissivo. As atividades religiosas, devido a sua função pragmática, constituem-se como atividades desaceleradas. Já que o rito não pode ter como pressuposto a categoria surpresa, configura-se, nesse discurso, a opção pela parada da parada que visa segurar o tempo e fazer com que ele não se mova tão rápido. Esse momento desacelerado diante do mundo institui a presença de práticas para que o sujeito, ao se sentir o "senhor de seu próprio tempo", tenha as suas expectativas cumpridas.

Uma vez que o sujeito tenha adquirido o "poder" (a disposição de base, a fim de que esse possa integrar-se ao rito eucarístico), o actante sujeito necessita do objeto modal "saber", obtido mediante a liturgia da palavra. De acordo com Blanco (2008, p. 51-52), “este programa modal trata de atualizar a competência cognoscitiva dos participantes do rito. É um programa em que predomina a extensidade sobre a intensidade, o inteligível sobre o sensível".

Com a liturgia eucarística, damos início ao momento central da Santa Missa. "A Missa como 'realização' iterativa e multiplicativa do sacrifício de Jesus Cristo na cruz constitui o ponto de intensidade mais alto do desenvolvimento da prática ritual” (BLANCO, 2008, p. 52).

A liturgia eucarística apresenta uma tensão constante entre as modalidades do conseguir e do sobrevir. "Do ponto de vista figural, o sobrevir e o conseguir são regimes de valências regidos pelo andamento" (ZILBERBERG, 2007, p. 19): 


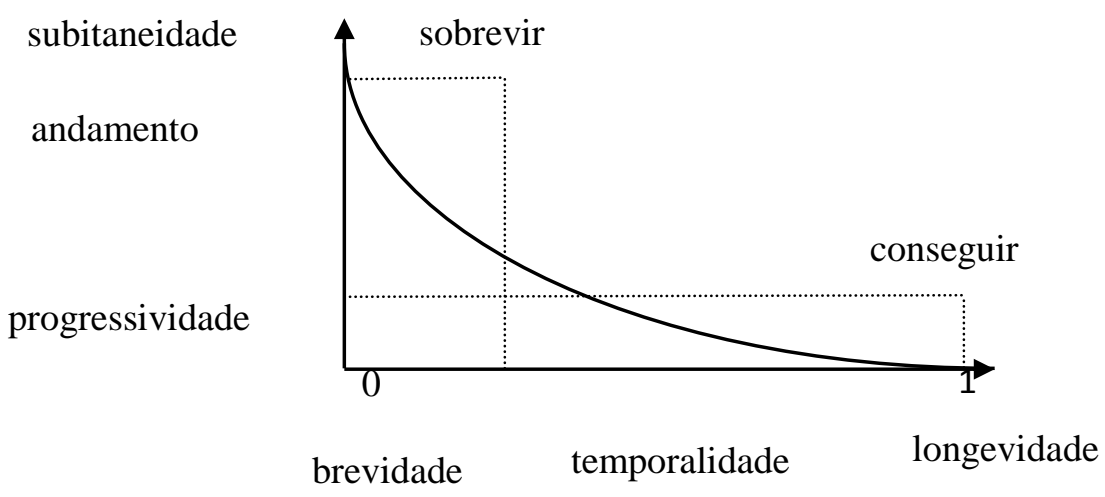

Figura 5. As modalidades do conseguir e do sobrevir.

Consoante a implicação, isto é, a doxa, temos a consagração do pão e do vinho, momento segundo o qual tem lugar a transubstanciação ${ }^{43}$ dessas espécies eucarísticas no corpo e sangue de Cristo, enquanto dogma para aquele que crê.De acordo com Zilberberg (2006), o acontecimento é o correlato objetal do sobrevir. O que, afinal, deveria ser comunicado ao enunciatário senão aquilo que lhe sobrevém e ao qual ele poderia crer, senão a partir do âmbito contratual da fé? O poder da palavra "Tomai, todos, e comei: isto é o meu Corpo, que será entregue por vós [...]. Tomai, todos e bebei: este é o cálice do meu Sangue" recai enquanto a intervenção de um acontecimento, que se sobrepõe a um enunciado de estado.

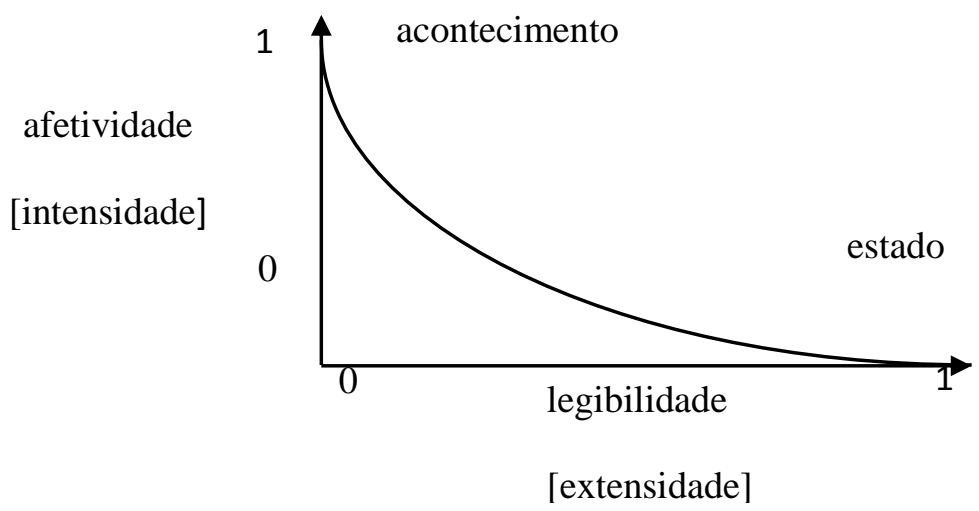

Figura 6. Discurso do estado e do acontecimento (ZILBERBERG, 2006, p. 142).

O discurso do exercício, próprio à lógica implicativa, opõe-se ao discurso dito do

\footnotetext{
43 "O Concílio de Trento resume a fé católica ao declarar: 'Por ter Cristo, nosso Redentor, dito que aquilo que oferecia sob a espécie do pão era verdadeiramente seu Corpo, sempre se teve na Igreja esta convicção, que o santo Concílio declara novamente: pela consagração do pão e do vinho opera-se a mudança de toda a substância do pão na substância do Corpo de Cristo Nosso Senhor e de toda a substância do vinho da substância do seu Sangue; esta mudança, a Igreja católica denominou-a com acerto e exatidão transubstanciação" (JOÃO PAULO II, 2000, p. 380).
} 
acontecimento. $\mathrm{O}$ acontecimento instaura, nesse momento da missa, um programa dado como irrealizável, a que se contrapõe um contraprograma que leva a termo a sua realização mediante o âmbito contratual através da fé (ZILBERBERG, 2006, p. 148). A doxa é determinada pela desaprovação do excesso. Ao se situar no eixo do exercício, ou seja, ao conseguir e à lentidão, próprias à lógica implicativa, ela se contrapõe ao acontecimento, pautado pela exclamação própria ao sobrevir. Faz-se, assim, a necessidade de um tempo lento a fim de aplacar a perturbação sofrida pelos fiéis diante da emergência do acontecimento. Essa desaceleração se caracteriza mediante uma série de posturas próprias ao rito eucarístico: “os movimentos rituais são lentos, os gestos do sacerdote são pausados, as palavras são pronunciadas com clareza e sossego" (BLANCO, 2008, p. 53). A lentidão confirma o éthos solene, da graça e da solenidade. "O tempo se converte em vivência sensível, graças a essa desaceleração dos movimentos" (BLANCO, 2008, p. 53). A aceleração, no momento da comunhão, estabelece a parada, por isso, é exclusiva. A ela se sobrepõe a desaceleração dos gestos e ações sacramentais após a comunhão. A desaceleração, de âmbito participativo, reincorpora o sujeito, que pode, dessa maneira, retomar a continuidade no programa modal de participação do rito eucarístico. Temos, nessa prática cerimonial, a presença de uma cifra, de um ritmo que reflete o próprio sujeito absorto diante do mistério da fé. O enunciado, ao manifestar uma direção ascendente a um estado de aceleração máxima [n+1], orienta-se para a atenuação do impacto dado mediante a degressividade (projeção no campo de presença de cada vez menos mais [n-1]). Vejamos:

Missa: ascendência $\rightarrow$ pico da ascendência $\rightarrow$ descendência

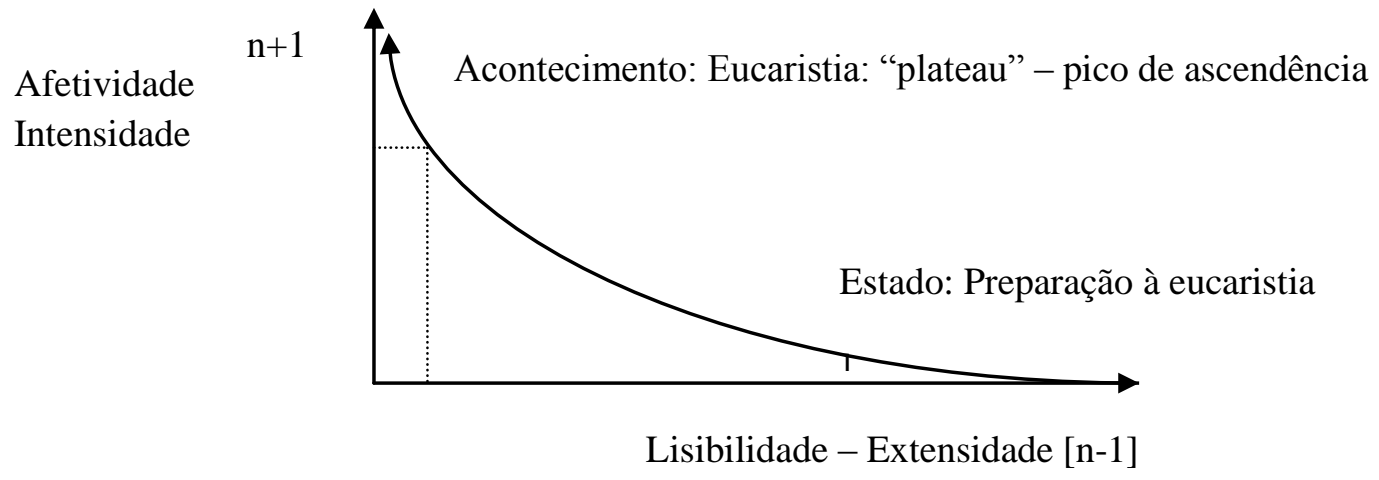

Figura 7. Parte de preparação à eucaristia: ascendência $\rightarrow$ pico da ascendência (Eucaristia). 


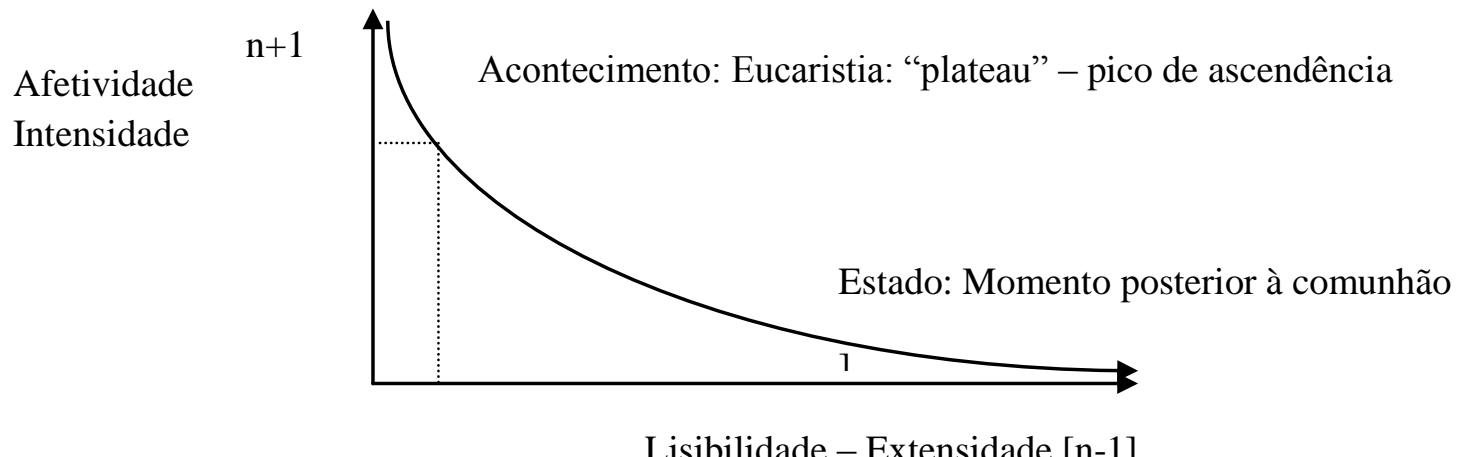

Figura 8. Parte subsequente à eucaristia.

Verificamos, pois, a projeção no enunciado do rito eucarístico de um estilo tensivo descendente, degressivo, que segue do "assomo" a "resolução" (ZILBERBERG, 2006, p. 15).

De acordo com Zilberberg (Idem, p. 151), temos, representado no gráfico a seguir, o valor realizado V1, definido pela intersecção das valências v' e v',, sobre a dimensão da intensidade. A orientação [V0 $\rightarrow \mathrm{V} 1]$ instaura uma orientação decrescente, de modo que v' depende da minimização da intensidade. Sobre a dimensão da extensidade, v' se situa na fase do restabelecimento da difusão. O acontecimento mediante a orientação [V1 $\rightarrow$ V0] instaura, em contrapartida, uma orientação ascendente.

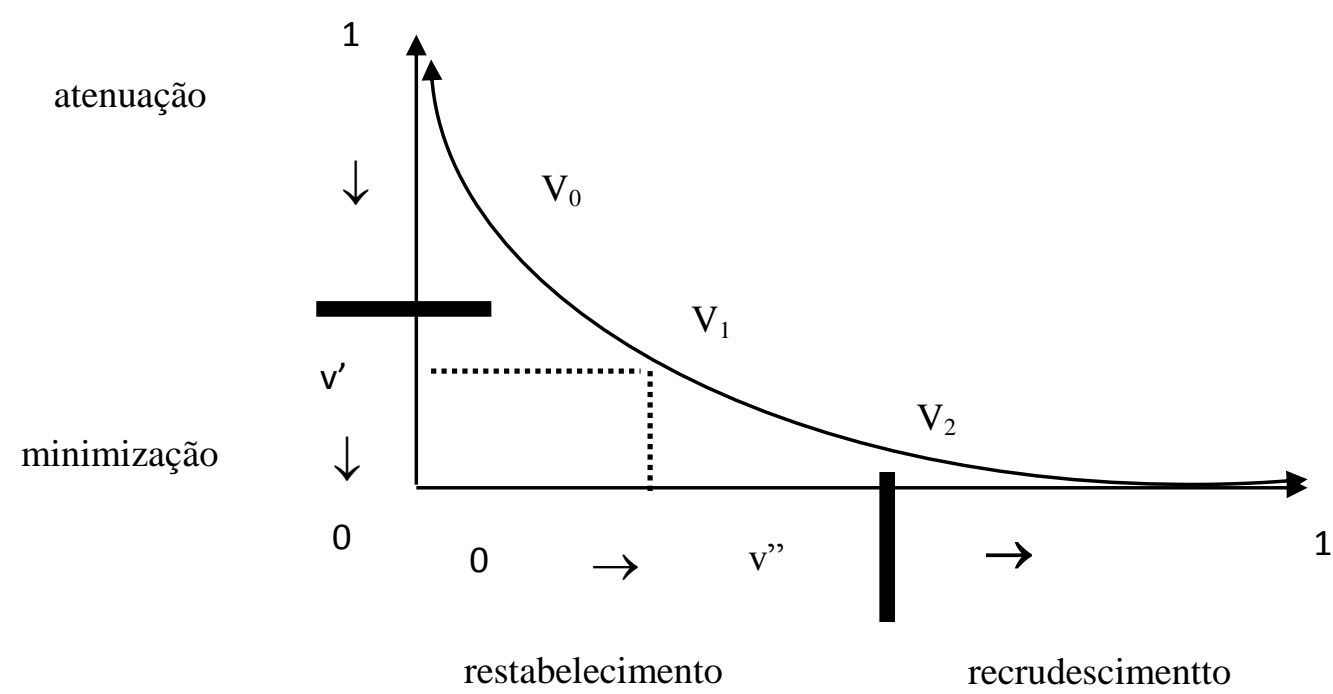

Figura 9. Projeção dos valores sobre um arco de correlação inversa (ZILBERGERG, 2006, p.151) 
Voltando para as bases narrativo-discursivas da semiótica, vemos que, se compreendemos a missa como um relato dramatizado, composto de palavras, movimentos e gestos contínuos, em uma determinada conduta ritual, remetemos a corpos que ocupam um determinado espaço tensivo. Remetemos, assim, à noção de actorialização, temporalização e espacialização própria ao nível discursivo do percurso gerativo do sentido.

Tomamos como princípio os mecanismos de sintaxe discursiva (debreagem e embreagem) com a instauração no enunciado das categorias de pessoa, tempo e espaço.

A presença do sagrado se efetua na noção de poder implicado nas palavras, o que remetemos aos usos da linguagem e às condições sociais de utilização das palavras.

Notamos a força ilocucionária das expressões, cujo poder reside na autoridade concedida ao porta-voz autorizado, no caso, o padre.

Há uma retórica característica de todos os discursos institucionais: a autoridade concedida à tomada da palavra pelo porta-voz autorizado coincide com os limites delegados pela instituição. As características da linguagem dos quadros dos porta-vozes delegados de quaisquer instituições (ex. sacerdotes) derivam da posição que ocupam esses depositários da autoridade delegada.

Não basta dizer que o uso da linguagem por parte de um locutor determinado, numa dada situação, com seu estilo, sua retórica e sua pessoa toda socialmente marcada, agrega às palavras "conotações" associadas a um contexto particular, introduzindo assim no discurso o excedente de significado que lhe confere sua "força ilocucionária". O uso da linguagem, ou melhor, tanto a maneira como a matéria do discurso, depende da posição social do locutor que, por sua vez, comanda o acesso que se lhe abre à língua da instituição, à palavra oficial, ortodoxa, legítima. (BOURDIEU, 1998, p. 87).

O poder das palavras reside não apenas no fato de terem sido proferidas por aquele que seria o "portador" delas, mas "na medida em que sua fala concentra o capital simbólico acumulado pelo grupo que lhe conferiu o mandato e do qual ele é, por assim dizer, o procurador" (BOURDIEU, 1998, p. 89).

O princípio de eficácia simbólica compreende: "a relação entre as propriedades do discurso, as propriedades daquele que o pronuncia e as propriedades da instituição que o autoriza a pronunciá-lo" (Idem, p. 89). 
Na missa, há um contrato de delegação de vozes que dá ao sacerdote o monopólio da manipulação dos bens de salvação. Esse contrato se manifesta no adequado cumprimento do código da liturgia (gestos e palavras sacramentais), bem como por meio da presença dos atributos simbólicos do magistério ${ }^{44}$ (a batina, o latim, os lugares e os objetos consagrados).

“A magia performativa do ritual funciona completamente apenas na medida em que o procurador religioso, incumbido de realizá-lo em nome do grupo, age como uma espécie de médium entre o grupo e ele próprio" (Idem, p. 95).

A "eficácia simbólica das palavras" é determinada pelo reconhecimento da autoridade do enunciador por parte do enunciatário.

Em sua celebração litúrgica, a assembléia inteira desempenha o papel de "liturgo", cada um segundo a sua função. O sacerdócio batismal é de todo o corpo de Cristo. Mas certos fiéis são ordenados pelo sacramento da Ordem para representar Cristo como cabeça do corpo (JOÃO PAULO II, 2000, p. 334).

Temos a actorialização característica do enunciado do folheto segundo a delimitação entre o que seria pronunciado apenas pelo portador autorizado, no caso, o padre, e as partes da missa a serem pronunciadas pelos fiéis. Essa disposição e delimitação de papéis definidos aparecem discursivizadas na própria composição diagramática do folheto. A letra "P" se refere à enunciação atribuída ao sacerdote e a letra " $T$ ", às respostas dirigidas pela comunidade. Essas respostas também apresentam destaque em negrito.

\section{Oração eucarística}

P. O Senhor esteja conosco

T. Ele está no meio de nós

P. Corações ao alto

T. O nosso coração está em Deus.

P. Demos graças ao Senhor, nosso Deus.

T. É nosso dever e salvação.

\footnotetext{
${ }^{44}$ Entendemos por magistério a "palavra latina que significa 'autoridade para ensinar'. De acordo com a doutrina católica, essa autoridade é conferida pelo Papa, ao sucessor de São Pedro e o chefe da Igreja, e aos Bispos em conjunto e em união com o Papa. Essa autoridade de ensinar é, em alguns casos, infalível e assim exige dos fiéis cristãos o consentimento da fé. Por outro lado, essa autoridade, mesmo quando não explicitamente infalível, expressa o autêntico ensinamento católico cristão e exige do fiel cristão a leal submissão da vontade e do intelecto" (LOWERY, 1999, p. 93).
} 
O narrador (implícito ao enunciado), por meio de uma debreagem enunciativa de segundo grau, delega voz aos actantes do enunciado (interlocutor e interlocutário), instaurando o diálogo. Observamos o estabelecimento do simulacro de uma interação ritualística sacramental por intermédio da distribuição do enunciado em uma estrutura de enunciação de fórmulas discursivas e sintagmas cristalizados. As questões possuem a forma imperativa a partir do emprego de fórmulas cristalizadas pertencentes à tradição discursiva da comunidade. Simula-se um jogo de vozes (a do interlocutor e a do interlocutário) que viabiliza o simulacro de um efeito dialogal.

Mediante a instauração dessa cena, obtém-se o efeito de sentido de distância maximizada entre enunciação e enunciado. Esse jogo de vozes entre actantes do enunciado constrói uma ilusão de realidade, a ilusão de uma situação real de enunciação do rito eucarístico.

Interlocutor (sacerdote, voz autorizada) e interlocutário (comunidade de fiéis) enunciam-se por meio do uso do pronome pessoal reto "nós". Esse "nós" configura-se como um "nós" inclusivo (eu + você + eles = nós, esta comunidade religiosa), nessa debreagem enunciativa de segundo grau.

Viabiliza-se o simulacro de um jogo de vozes, o "nós" que enuncia e o "nós" que responde, com a utilização da mesma pessoa gramatical: um nós generalizado, de toda pessoa, lugar e espaço.

P. Irmãos e irmãs, elevemos nossas preces ao Pai, pedindo-lhe a graça da fidelidade no testemunho de Cristo e na unidade entre os cristãos, rezando juntos:

\section{T. Enviai-nos, Senhor, vosso Espírito de amor!}

Nesse último caso, afirma-se pela utilização do pronome "vós" a distância entre o sujeito "nós" (comunidade eucarística) e o arquidestinador divino, intermediada pelo sacerdote: "Lembrai-vos, ó pai dos vossos filhos".

Verifica-se, também, enquanto argumento de autoridade que tem por objetivo validar a prática do sacrifício eucarístico, a instauração de uma debreagem enunciativa de segundo grau que delega voz ao próprio Cristo e encontra-se disposta diagramaticamente em caixa alta. Essa sequência injuntiva remete ao caráter sacrifical do corpo e sangue de Cristo, figurativizada sob as espécies eucarísticas do pão e do vinho. A palavra divina institui-se no enunciado como um performativo absoluto. 
TOMAI, TODOS, E COMEI: ISTO É O MEU CORPO, QUE SERÁ ENTREGUE POR VÓS [...]. TOMAI, TODOS E BEBEI: ESTE É O CALÍCE DO MEU SANGUE, O SANGUE DA NOVA E ETERNA ALIANÇA, QUE SERÁ DERRAMADO POR VÓS E POR TODOS, PARA REMISSÃO DOS PECADOS, FAZEI ISTO EM MEMÓRIA DE MIM.

Por sua vez, observa-se a presença da primeira pessoa do plural por meio do vocativo que afirma o chamamento do sujeito dado por meio do sintagma cristalizado: "Recebei, ó Senhor, a nossa oferta. O "nós", representado por meio do interlocutor (comunidade eucarística), dirige-se, em oração, a Cristo, Nosso Senhor. Isso reforça o caráter invocativo do sujeito em falta, elidido e disposto numa posição de inferioridade.

O enunciado do folheto operacionaliza uma debreagem temporal enunciativa, uma vez que "se projetam no enunciado os tempos do sistema enunciativo" (FIORIN, 2002, p. 147). Nesse nível, a debreagem actorial será dita de segundo grau, por se encontrar relacionada à categoria do interlocutor, delegada do narrador implícito e instaurada na forma de diálogo.

Estando construído dentro do sistema enunciativo, o enunciado do folheto litúrgico pauta-se em relação ao "agora", em concomitância ao marco referencial presente. Relacionase, portanto, a um momento de referência presente, idêntico ao momento da enunciação.

O tempo verbal característico desse discurso é o presente omnitemporal ou gnômico, fato que o constitui como um enunciado válido para qualquer lugar ou época histórica e o caracteriza como um enunciado próprio da esfera de circulação do discurso religioso, utilizado para a enunciação de verdades eternas.

O texto do folheto litúrgico, ao ser organizado ao redor da instância do "aqui", simula uma cena enunciativa por meio da instauração do diálogo. O espaço linguístico é expresso no enunciado do folheto mediante a utilização dos advérbios de lugar. Observamos a presença do advérbio enunciativo (aqui): "T. Em comunhão com toda a Igreja aqui estamos!”. "Aqui”" marca o espaço da cena enunciativa, sendo que este assinala o espaço do nós, da comunidade eucarística que se dirige em direção superativa ao vós arquienunciador divino.

A cena dialógica caracteriza-se pela irreversibilidade de posições enunciativas: Jesus Cristo/ Espírito Santo (lá), comunidade de fiéis (aqui) e o sacerdote como intermediário entre os planos espaciais (aqui) e o espiritual (lá). O enunciado constrói, por meio da irreversibilidade, uma proxêmica dada na ordem da estabilidade ${ }^{45}$. A estaticidade, que

\footnotetext{
45 "A proxêmica é uma disciplina - ou melhor, um projeto de disciplina - semiótica que visa a analisar a disposição dos sujeitos e dos objetos no espaço e, mais particularmente, o uso que os sujeitos fazem do espaço para fins de significação" (GREIMAS; COURTÉS, 2008, p. 395).
} 
permeia a formação ideológica considerada, produz o simulacro de um mundo estabilizado com lugares definidos.

A figura de Jesus Cristo/Espírito Santo, ao se instituir na ordem do inefável, transcende os limites humanos e consolida a isotopia da santidade.

Temos, portanto, a espacialização dada na ordem da verticalidade, pautada pela direção superativa no eixo da verticalidade. O olhar da verticalidade constrói o plano espiritual a partir do ponto de vista eufórico, estabelecendo o "alto" como categoria eufórica. Seu olhar, mediado pela instância intermediadora do agente religioso, estabelece-se por meio do "baixo" (disfórico) para o "alto" (eufórico).

\section{ORAÇÃO APÓS COMUNHÃO}

P. Oremos (silêncio): Deus eterno e todo-poderoso, que nos concedeis conviver na terra com as realidades do céu, fazei com que nossos corações se voltem para o alto, onde está junto de vós a nossa humanidade. Por Cristo, nosso Senhor.

T. Amém.

Por meio desse exemplo, adquirimos a visão do baixo disfórico, do sujeito em falta, um sujeito que não é, mas pode vir a ser por meio da invocação oracional pautada na fé.

A disposição espacial própria ao rito eucarístico se desdobra na demarcação entre o espaço sagrado e o espaço profano. Retomamos a prevalência das operações de triagem (ZILBERBERG, 2004), que caracterizam a instituição de um espaço ritual pautado por um deslocamento horizontal, segundo o qual se distribui "uma região sagrada, separada e protegida de tudo aquilo que a rodeia, e uma região profana, ou não sagrada acessível a todas as pessoas" (BLANCO, 2008, p. 48).

Verificamos um acento de valor apreciativo, transmitido por uma entonação expressiva e afetiva, conforme a qual o espaço sagrado remete a um acento de intensidade e o espaço profano se caracteriza pela extensidade. Remetemos a tonicidade ou a atonia das percepções, ao tipo perceptivo do foco e da apreensão (ZILERBERG; FONTANILLE; 2001, p. 129). Ao tipo perceptivo do foco (espacialização fechada) associamos o espaço sagrado; ao tipo perceptivo da apreensão (espacialidade aberta), o espaço profano.

Vejamos o seguinte esquema (BLANCO, 2008, p. 49, tradução nossa) ${ }^{46}$ :

\footnotetext{
${ }^{46}$ Ressaltamos que se fizeram necessárias algumas restrições ao pensamento de Blanco (2008), a partir de Zilberberg (2006). Embora Blanco (2008) se utilize da oposição entre "acento tônico", em referência à intensidade, e "ausência de acento", no que tange à extensidade, optamos por substituí-los, respectivamente, no
} 


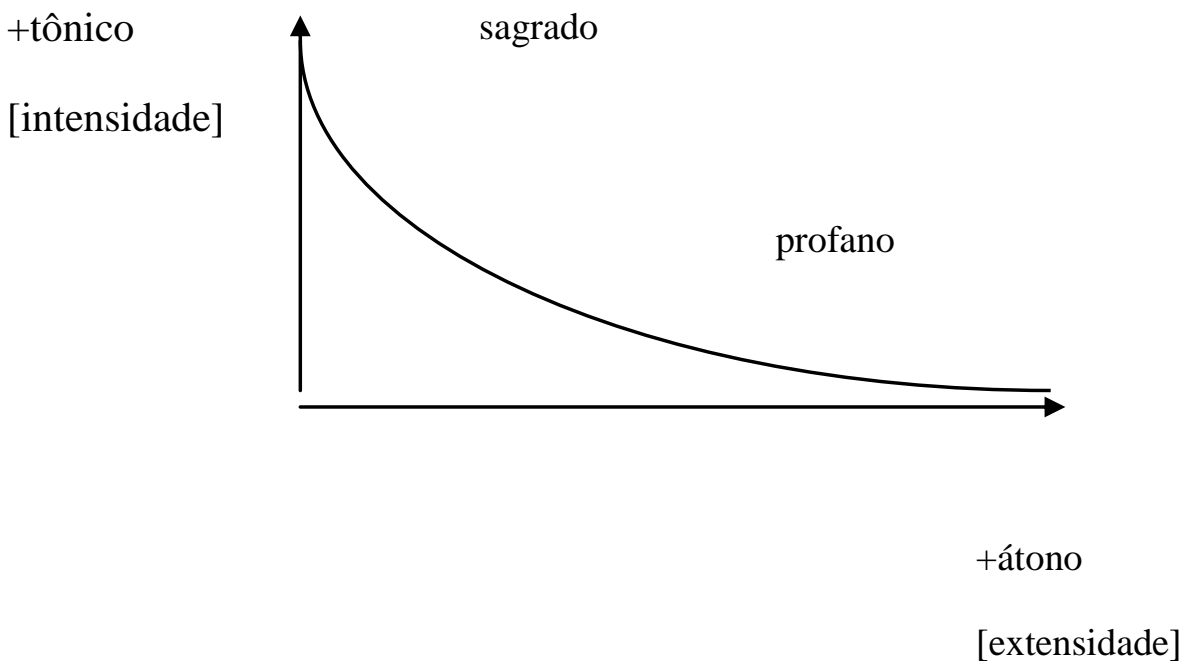

Figura 10. Oposição entre o sagrado e o profano.

Dentro do templo, podemos considerar, ainda, uma gradação da tonicidade do espaço sagrado. A tonicidade confere um determinado "acento de sentido" a cada um dos segmentos que compõe o discurso. O espaço do templo e sua disposição configuram-se como um discurso que fala a seus fiéis (BLANCO, 2008, p. 49). Consideramos a disposição das quatro partes das quais se constitui o templo, tido enquanto espaço sagrado das práticas rituais católicas: sacrário, presbitério (altar), naves e átrio.

a) Sacrário (tabernáculo): presença das espécies consagradas (corpo de Cristo);

b) Presbitério (altar): centro da Igreja, nele se faz presente o Sacrifício da Cruz sob os sinais sacramentais.

c) Naves: disposição dos fiéis;

d) Átrio: pátio interno (trânsito entre o sagrado e o profano).

Observemos como se configura a gradação do espaço tensivo do templo sob o parâmetro da tonicidade. Retomamos e ampliamos o gráfico original apresentado por Blanco (2008, p. 49).

gráfico apresentado, pelos termos "tônico" e "átono", tal como utilizados por Zilberberg (2006), a fim de que não tivéssemos incongruências na tese. 
Tônico [+sagrado]

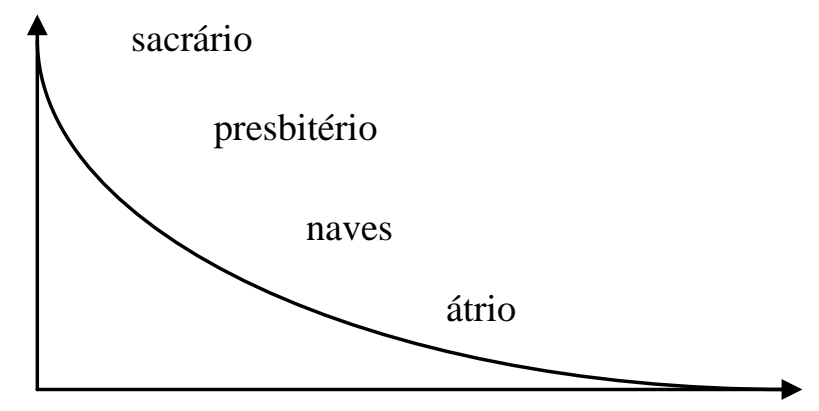

Átono [+profano]

Figura 11. Gradação do espaço tensivo no templo.

O átrio, passagem entre o sagrado e o profano, apresenta um acento de sentido débil, quase nulo. As naves constituem o espaço mais amplo do templo, onde se situam os fiéis (actantes coletivos) dispostos à participação no rito da missa. Consolida-se a atitude de participação dos fiéis, dada mediante um conjunto de posturas e disposições com os quais esses se colocam diante do sagrado.

Entre essas atitudes, podemos destacar a presença de momentos contemplativos, de silêncio, de cânticos etc, determinada no enunciado do folheto por meio de marcas enunciativas (BLANCO, 2008, p. 50). Vejamos:

\footnotetext{
HINO DE LOUVOR (preferencialmente cantado)

P. Glória a Deus nas alturas,

T. e paz na terra aos homens por Ele amados [...].
}

\section{ORAÇÃO}

P. Oremos (silêncio): Ó Deus todo poderoso, a ascensão de vosso filho já é nossa vitória [...].

O presbitério destina-se ao celebrante (porta-voz autorizado) e seus acompanhantes. O acento de sentido adquire nesse espaço um grau ainda mais alto de tonicidade. O tabernáculo, lugar das espécies consagradas, constitui-se como um lugar sacratíssimo por excelência, lugar em que se consolida a totalidade culminante no âmbito total do sagrado (Idem, p. 50). 


\subsection{Prática Semiótica: Roteiro Preparatório de Confissão}

O pecado é antes de tudo uma ofensa a Deus, uma ruptura da comunhão com ele. Ao mesmo tempo é um atentado à comunhão com a Igreja. Por isso, a conversão traz simultaneamente o perdão de Deus e a reconciliação com a Igreja, o que é expresso e realizado liturgicamente pelo sacramento da Penitência e da Reconciliação.

João Paulo II $^{47}$

A economia sacramental católica "consiste em comunicar os frutos da redenção de Cristo, mediante a celebração dos sacramentos da Igreja, principalmente da Eucaristia" (BENTO XVI, 2005, p. 79).

Os sacramentos são sinais eficazes de graça, instituídos por Cristo e confiados à Igreja, por meio dos quais nos é dispensada a vida divina. Os ritos visíveis sob os quais os sacramentos são celebrados significam e realizam as graças próprias de cada sacramento. Produzem efeito naqueles que os recebem com as disposições exigidas (JOÃO PAULO II, 2000, p. 319).

São sete os sacramentos da Igreja: Batismo, Confirmação, Eucaristia, Penitência, Unção dos Enfermos, Ordem e Matrimônio. Eles apresentam a seguinte distinção: sacramentos de iniciação cristã (Batismo, Confirmação e Eucaristia); sacramentos da cura (Penitência e Unção dos Enfermos); sacramentos a serviço da comunhão e da missão (Ordem e Matrimônio).

Dentro da ritualística sacramental católica, estabelecemos como recorte a análise do sacramento da penitência ou reconciliação. A prática católica da confissão, também designada "sacramento da penitência ou reconciliação", sinal de preparo à comunhão, constitui a busca pela absolvição sacramental e a reintegração entre os membros partícipes da formação ideológica católica.

Aqueles que se aproximam do sacramento da Penitência obtêm da misericórdia divina o perdão da ofensa feita a Deus e ao mesmo tempo são reconciliados com a Igreja que feriram pecando, e a qual colabora para sua conversão com caridade, exemplo e orações (JOÃO PAULO II, p. 392).

${ }^{47}$ João Paulo II (2000, p. 397). 
Tomamos o enunciado do folheto preparatório de confissão, enquanto subprática manifestada no objeto-suporte dessa prática semiótica. Teremos, portanto, associados a uma morfologia particular do objeto de escrita, dois tipos de prática: uma, instaurada pelo gênero, o qual denominamos folheto de preparação para a confissão e outra, pela comunicação e circulação dos objetos em sociedade, representada no enunciado pela experiência da palavra na prática religiosa, ambas relacionadas uma a outra (FONTANILLE, 2004, p. 21-22).

Ao longo da análise dos procedimentos argumentativos empregados no enunciado, conceberemos a argumentação e a arte retórica como práticas:

O discurso persuasivo é apreciado no nível do texto, mas a argumentação, da maneira como é considerada pela retórica geral, é uma prática e a pertinência de cada argumentação particular só pode ser estabelecida no âmbito de uma estratégia (FONTANILLE, 2008, p. 38).

No que diz respeito ao exame do enunciado relativo à prática católica do sacramento da confissão (penitência), considerá-lo-emos enquanto um discurso próprio ao acontecimento, isso, pois, a confissão, para cada um que a realiza, constitui um acontecimento singular. Retomamos a noção de eficiência práxica própria à confissão, determinada pela sua organização sintagmática. Remetemos ao enunciado do folheto sob a designação T6, presente no vol. II, referente aos anexos desta tese.

Na prática da confissão, temos a relação entre o homem, a fé (crença), o pecado e o dogma. Observamos, no enunciado, a presença da direção superativa no eixo da verticalidade. O olhar da verticalidade constrói o plano espiritual a partir do ponto de vista eufórico, estabelecendo o "alto" como categoria eufórica. Delineia-se o olhar do sujeito por meio do "baixo" (disfórico) para o "alto" (eufórico). No que concerne à organização da sequência narrativa, notamos a direcionalidade tensiva do eu (pecador arrependido) em direção a Cristo nosso Senhor por intermédio do sacerdote. Inicialmente, o sujeito patêmico (pecador, instaurado no enunciado) do folheto configura essa inclinação, a qual podemos definir como uma espécie de "ressentir" "do estado limite e espera do retorno da fusão" (GREIMAS; FONTANILLE, 1993, p. 30). Essa espera repousa sobre a fidúcia. Verificamos, assim, a dimensão passional do sujeito pautada pela expectativa de retorno aos valores com os quais este teria se desvinculado, expectativa essa, que designamos em semiótica, de protensividade fórica. "A protensividade é o primeito efeito da cisão, a orientação é sua propriedade figural, o devir é o produto de um desequilíbrio de tensões que confirma a cisão". (GREIMAS; 
FONTANILLE, 1993, p. 33). No que diz respeito aos dispositivos passionais do ser, observamos, tal como demonstram Greimas e Fontanille (Idem, p. 61), a presença das configurações passionais nos dicionários enquanto "disposição", "sentimento que leva a", “disposição", "inclinação".

Essa protensividade, concebida como orientação, devir do sujeito, pauta-se no enunciado na busca do retorno de uma nova expectativa de conversão, para que ele possa obter o objeto valor "graça divina", sendo reintegrado, portanto, ao sistema de valores proposto pelo catolicismo. Entendemos a disposição do sujeito "pecador arrependido", inicialmente conjunto com valores disfóricos (prática do pecado), em busca de conversão e reintegração aos valores tidos eufóricos (obediência aos mandamentos da lei de Deus). Concebemos essa disposição do sujeito como uma aspectualização temporal, imediatamente identificável ao universo passional, segundo a qual reconhecemos a protensividade, “definindo um sujeito tensivo, ou 'quase sujeito', e que engendra, sob o efeito das paixões favoráveis à cisão, o devir e, por outro lado, a fidúcia, sobre a qual se desenham 'sombras de valor' destinadas a engendrar as valências" (GREIMAS; FONTANILLE, 1993, p. 76) .

Percebemos a figura de um arquidestinador divino (Deus, Espirito Santo) atingível apenas mediante a figura do confessor, tido enquanto mediador capaz de restabelecer o fluxo fórico do sujeito, reintegrando-o a tais valores.

"Coloque-se diante de Deus. Ele quer acolhê-lo com Seu grande amor. Pelo Espírito Santo Ele revela Sua imensa Misericórdia, compreende suas fraquezas e perdoa suas faltas".

Verificamos, ao longo de todo o enunciado, o uso de verbos no imperativo, que determinam a realização de uma determinada "conduta" ritual por parte do sujeito:

"Coloque-se diante de Deus".

"Faça o sinal da Cruz e reze a Oração do Credo. Medite a Palavra de Deus".

"Ore com estes textos bíblicos".

"Diga a Deus que está arrependido e quer fazer uma boa confissão".

"Olhe para dentro de você mesmo [...]"

"Peça perdão sincero a Deus, mostre arrependimento por ter errado, e faça o propósito de lutar contra o mal e as tentações, e de se corrigir".

"Reze o Pai Nosso, Ave Maria, Glória e o Ato de Contrição.

"Volte-se ao Senhor para agradecer e fazer a penitência determinada pelo sacerdote".

"Prometa ser um bom cristão e melhorar a cada dia".

"Implore pela intercessão de Maria. Peça auxílio e a graça do Espírito Santo para permanecer em estado de graça" (grifos nossos). 
Ainda no que diz respeito à práxis do ritual, observamos a presença das seguintes performances a ser executadas pelo sujeito e apresentadas no roteiro de preparação para a confissão: exame de consciência; contrição (arrependimento); confissão (acusação dos pecados perante o sacerdote) e satisfação (cumprimentos de certos atos de penitência que o confessor impõe ao penitente para reparar o dano causado pelo pecado) (BENTO XVI, 2005, p. 99). No caso do enunciado do folheto, temos o seguinte discurso fundador bíblico, exibido logo no início do folheto: "Medite a palavra de Deus: Ef 1, 3-7, Col 3, 1-17; Cor 13, 1-7".

a) Exame de consciência

Ao considerarmos o primeiro dos atos do penitente, o exame de consciência, obtemos a configuração do imaginário passional do sujeito. A disjunção como primeira modalização do sujeito resulta em um simulacro existencial que configura no discurso o aspecto do sujeito. Aqui, mais do que uma performance do sujeito, temos um processo de aquisição de competência, na qual o sujeito deve adquirir o poder ser e saber ser necessários a sua nova conversão e reintegração.

"Olhe para dentro de você mesmo e se pergunte, recordando os mandamentos da lei de Deus, da Lei da Igreja, e os Pecados Capitais".

Veremos, assim, como se configura, no enunciado, o percurso passional do sujeito "arrependido", fundado na conjunção com um antiobjeto "pecado", e que projeta a imagem disfórica de um sujeito realizado. "Chama-se Sacramento da Conversão, pois ele realiza sacramentalmente o convite de Jesus à conversão, o caminho de volta ao Pai, do qual a pessoa se afastou pelo pecado" (JOÃO PAULO II, 2000, p. 392).

Assinalamos, dessa forma, o modo de ser do sujeito da enunciação que busca se reintegrar ao sistema de valores proposto pelo catolicismo.

O sujeito visto mediante o simulacro existencial de conjunção com um antiobjeto é percebido ao longo da práxis do ritual (ações do penitente) sob a intensidade do sentir. 
b) Contrição (arrependimento)

Entre os atos do penitente, a contrição se constitui como a primeira entre as performances a ser executada pelo sujeito, dado que o exame de consciência se estabelece enquanto um programa de aquisição de competência, tal como vimos na seção anterior. "Entre os atos do penitente, a contrição vem em primeiro lugar. Consiste numa dor da alma e detestação do pecado cometido, com a resolução de não mais pecar no futuro" (JOÃO PAULO II, 2000, p. 400). Vejamos:

"Peça perdão sincero a Deus, mostre arrependimento por ter errado, e faça o propósito de lutar contra o mal e as tentações, e de se corrigir".

$\mathrm{O}$ ato de contrição é realizado, enquanto performance do sujeito, por intermédio da seguinte fórmula:

"Meu Deus, eu me arrependo de todo o coração de Vos ter ofendido porque sois tão bom e amável. Prometo com vossa Graça esforçar-me para ser bom. Meu Jesus, Misericórdia".

c) Confissão dos pecados ao sacerdote

No que diz respeito à confissão, por meio da perfomance da acusação dos pecados diante do sacerdote, "o homem encara de frente os pecados dos quais se tornou culpado: assume a responsabilidade deles e, assim, abre-se de novo a Deus e à comunhão da Igreja, a fim de tornar possível um futuro novo" (Idem, p. 400-401).

Observamos, nessa relação de mediação, na qual o sujeito se encontra disjunto com os valores propostos pelo catolicismo, uma espera fiduciária, dado ser necessária a mediação do confessor (sacerdote), que deve ter a autoridade e competência (saber-ser e poder-ser) necessária para o exercício de sua função.

Deve possuir um comprovado conhecimento do comportamento cristão, experiência das coisas humanas, respeito e delicadeza diante daquele que caiu; deve amar a verdade, ser fiel ao magistério da Igreja e conduzir, com paciência, o penitente à cura e à plena maturidade (JOÃO PAULO II, 2000, p. 404). 
d) Satisfação (penitência)

Temos, na satisfação, a penitência imposta pelo confessor e que se dá mediante a realização de uma performance determinada pelo sujeito de mediação (sacerdote).

"Volte-se ao Senhor para agradecer e fazer a penitência determinada pelo sacerdote; se possível, diante do Sacrário. Prometa de novo ser bom cristão e melhorar a cada dia. [...] Implore pela intercessão de Maria. Peça auxílio e a graça do Espírito Santo para permanecer em estado de graça".

Após a realização dos atos do penitente, o destinador-julgador, ao julgar positivamente seus atos, concede-lhe a sanção pragmática da absolvição dos pecados e reintegração a formação católica. Esses atos de satisfação constituem a penitência.

Assim, tendo o fiel católico como leitor pressuposto, o "outro", ao qual este discurso se destina, o destinador do texto católico estabelece uma catequese sobre os princípios dogmáticos do catolicismo para fazer com que o leitor, por meio de uma manipulação baseada na intimidação (se o fiel não realizar adequadamente a práxis proposta), coloque sua confiança em Cristo Nosso Senhor, por intermédio da figura do sacerdote, peça perdão pelos pecados cometidos (transgressão da ordem proposta), cristalize sua fé em Deus, cumpra a penitência proposta pelo sacerdote e, consequentemente, seja sancionado positivamente para que possa alcançar a salvação por meio da instituição do sacramento da reconciliação e se integrar novamente ao sistema de crença proposto pelo catolicismo.

O PN estabelecido pelo destinador-manipulador, para que o sujeito permaneça conjunto com tais valores, corresponde ao fazer emissivo, que também poderíamos denominar continuativo, por nele privilegiarmos a dominância da temporalidade emissiva (parada da parada), responsável pelas experiências conjuntivas pautadas pela extensão, duração e apreensão do percurso de busca do $\mathrm{O}_{\mathrm{v}}$ "graça divina" empreendido pelo sujeito (permanecer em estado de graça). O antiprograma, realizado de modo implícito pelo antidestinador (mal e as tentações), refere-se ao fazer remissivo, à parada, o qual remetemos ao conceito de surpresa, responsável pela ruptura da relação contratual entre destinador e destinatário e pela interrupção do fluxo fórico.

$\mathrm{O}$ sujeito, já conjunto com o $\mathrm{O}_{\mathrm{v}}$ "dom da graça divina”, receberá o $\mathrm{O}_{\mathrm{m}}$ "poder ter o poder e força para resistir aos assaltos da tentação". As temáticas do combate, da defesa da vida Divina e da Santa Igreja se verificam nesse enunciado. 
Constrói-se a imagem de um sujeito que, ao agir conforme as prescrições estabelecidas, permanecerá conjunto com tais valores.

Remetemos, assim, aos efeitos de passionalização do sujeito do discurso de fidelização religiosa, nesse âmbito ora considerado. Temos como característica do enunciado da confissão a direcionalidade tensiva orientada para o grau máximo de tonicidade e aceleração. A performance referente à práxis do penitente, ao se situar no eixo do exercício, ou seja, ao conseguir e à lentidão, próprios à lógica implicativa, opõe-se ao acontecimento do ato da confissão, pautado pela exclamação inerente ao sobrevir. Verificamos, nesse sentido, a exposição das práxis do penitente mediante uma concepção descendente, pertencente à lógica implicativa. Delineamos, desse modo, o estilo do enunciado da experiência da palavra (prática católica da confissão) por meio de uma direção descendente, intrínseca à lógica implicativa. 


\section{Cap. III}

\section{A TOTALIDADE DISCURSIVA DE DIVULGAÇÃO RELIGIOSA}

Em uma sociedade marcada pela influência dos meios de comunicação e pela pluralidade de opiniões, pessoas e organizações disputam a possibilidade de utilizar os recursos e as técnicas disponíveis pela tecnologia e pela comunicação, a fim de divulgar, com eficácia, seus pontos de vista, seus objetivos, suas concepções de ser humano, de mundo e de sociedade e, assim, interferir nas decisões que pautam a vida das pessoas. Essa tendência também está presente nas instituições religiosas, o que faz com que padres e pastores, religiosos e leigos, missionários e pregadores procurem, cada vez mais, espaço nas telas de televisão, nas emissoras de rádio, nos jornais impressos, na internet e em outras possibilidades de comunicação.

Lindolfo Alexandre de Souza ${ }^{48}$

\footnotetext{
${ }^{48}$ Souza (2011, p. 13).
} 


\section{Discurso de divulgação religiosa}

Faz-se necessário que estabeleçamos, inicialmente, a definição dos termos: universo discursivo e campo discursivo, introduzidos por Maingueneau (2005), na linha teórica da AD francesa. Conforme essa concepção, denominamos universo discursivo o "conjunto de formações discursivas de todos os tipos que interagem numa conjuntura dada" (MAINGUENEAU, 2005a, p. 35). Ao definir uma extensão máxima de análise, essa noção se constitui como um elemento de pouca utilidade para o analista que "é levado a recortar campos discursivos, em que um conjunto de formações discursivas ${ }^{49}$ (ou de posicionamentos $^{50}$ ) estão em concorrência no sentido amplo, delimitando-se reciprocamente" (CHARAUDEAU; MAINGUENEAU, 2004, p. 91).

Isolamos para esta tese um campo de divulgação religiosa, ao invés de nos remeter diretamente ao campo religioso. Retomando o que se entende por campo discursivo, referimonos ao conjunto de textos voltados para uma prática: a divulgação religiosa.

Temos como ponto de partida os dois eixos fundamentais segundo os quais a pesquisa de Discini (2004b) se apoia: a) como são estabelecidas, no interior de um universo discursivo, as totalidades que configuram um estilo; b) como o estilo constrói o éthos do enunciador.

"Estilo é, então, totalidade, enquanto unidade integral (unus) e enquanto totalidade integral (totus), sendo que um termo pressupõe outro, numa relação de interdependência" (Idem, p. 34).

Cada enunciado de divulgação religiosa é, portanto, um unus (unidade integral) que remete a um totus, que compreende a totalidade dos enunciados de divulgação religiosa. "Se é por meio do exame de uma totalidade de enunciados que se obtém o efeito de individualidade,

\footnotetext{
49 "Noção usada essencialmente na Escola francesa, a formação discursiva foi introduzida por Foucault (1969: 53) para designar conjuntos de enunciados relacionados a um mesmo sistema de regras, historicamente determinadas. [...] Toda formação social, passível de se caracterizar por uma certa relação entre classes sociais, implica na existência de posições políticas e ideológicas, que não são o feito de indivíduos, mas que se organizam em formações que mantêm entre si relações de antagonismo, de aliança ou de dominação. Essas formações ideológicas constituem uma ou várias formações discursivas interligadas, que determinam o que pode e deve ser dito [...] a partir de uma posição dada numa conjuntura dada" (MAINGUENEAU, 2006, p. 67-68).

50 "Num campo discursivo, 'posicionamento' define mais precisamente uma identidade enunciativa forte [...], um lugar de produção discursiva bem específico. Esse termo designa ao mesmo tempo as operações pelas quais essa identidade enunciativa se instaura e se conserva num campo" (CHARAUDEAU; MAINGUENEAU, 2004, p. 392).
} 
o texto considerado para análise de um estilo deve ser entendido como unidade correlata a uma totalidade" (Idem, 2008, p. 35).

Assim sendo, como se constrói a imagem do ator da enunciação, o éthos como estilo?

Se apenas um enunciado de divulgação fosse examinado, teríamos unicamente a imagem do narrador de tais discursos. Embora o todo esteja na parte, a fim de que possamos obter o ator da enunciação, visto na totalidade de seus discursos, faz-se necessário ao analista depreender, em um grupo de dois ou mais textos reunidos para fins de estudo, um conjunto de traços recorrentes do plano do conteúdo e do plano de expressão. Portanto, torna-se possível compreender, por meio da análise da totalidade, um efeito de sentido de identidade e que configura uma enunciação única.

Segundo os estudos desenvolvidos por Discini (2004b), temos o percurso gerativo do sentido como ferramenta necessária para determinar o estilo em uma totalidade de discursos enunciados. Obtemos, assim, o éthos do enunciador da divulgação religiosa como efeito de sentido de uma totalidade enunciada.

Para que analisemos as recorrências encontradas na materialidade discursiva da totalidade, enquanto elemento composicional do discurso ou texto, e que configuram um fato de estilo, devemos referir, principalmente, às coerções genéricas que perpassam a construção desse efeito de individuação, uma vez que o gênero é responsável por projetar expectativas no enunciatário, adequadas à situação de enunciação.

Temos uma cena genérica que corresponde ao contrato associado aos gêneros de divulgação religiosa (encíclica, compêndio, artigos jornalísticos e entrevistas em revistas e jornais de divulgação religiosa especializada, entre outros). Entretanto, vemos como cada enunciação caracteriza, de fato, uma cenografia, pela sua maneira específica de inscrever-se e pela recorrência de um modo individualizador do dizer, inscrito no próprio enunciado de divulgação.

Feitas essas considerações, a fim de que possamos estabelecer o modo de presença da totalidade de divulgação religiosa, retomemos a estrutura mínima do dizer, proposta por Zilberberg (2007, p. 14), tal como pode ser observada mediante a seguinte esquematização: 
A comunicação, como é vista nos discursos de divulgação, dos quais nos utilizamos em nossa pesquisa, caminha em uma direção contrária à observada com relação às modalidades veridictórias de discursos de outra natureza, nos quais há o predomínio de uma retórica da retenção (conservação). Nos discursos divulgadores há o privilégio à partilha (ZILBERBERG, 2007, p. 14-15).

Concebemos, assim, os discursos de divulgação como aqueles que se valem da "partilha da veridicção", na medida em que estes se caracterizam pela propagação e difusão de saberes, crenças, ideais, valores e pontos de vista, de uma formação discursiva determinada. Para corroborar essa hipótese, tomemos, inicialmente, a própria concepção de divulgação:

Divulgar [Do lat. divulgare.] 1.Tornar público ou notório; publicar; propagar, difundir, vulgarizar. [...] 2. Tornar-se público ou conhecido; propagar-se, difundir-se [Var. ant.: devulgar. Conjug.: v. largar.] (FERREIRA, 2004).

Divulgar vb.'vulgarizar, tornar conhecido, propalar, publicar'| devulgar $\mathrm{XV} \mid$ Do lat.divulgāre\| divulgaÇÃO 1873. Do lat. divulgātîoōnis \|divulgaDOR 1813. Do lat. Divulgatōr-ōris (CUNHA, 1982, p. 273).

Vejamos a demonstração da noção de divulgação, tomando para nós o diagrama tensivo ${ }^{51}$.

\footnotetext{
51 "Entendemos por diagrama a representação gráfica convencional do espaço tensivo pela qual o eixo das ordenadas corresponde à intensidade e o eixo das abscissas à extensidade. Os valores de limite inferior da intensidade e da extensidade são, respectivamente: /tênue/ e /concentrada/; os de limite superior são: /impactante/ e /difusa/" (ZILBERBERG, 2006a, p. 207).
} 


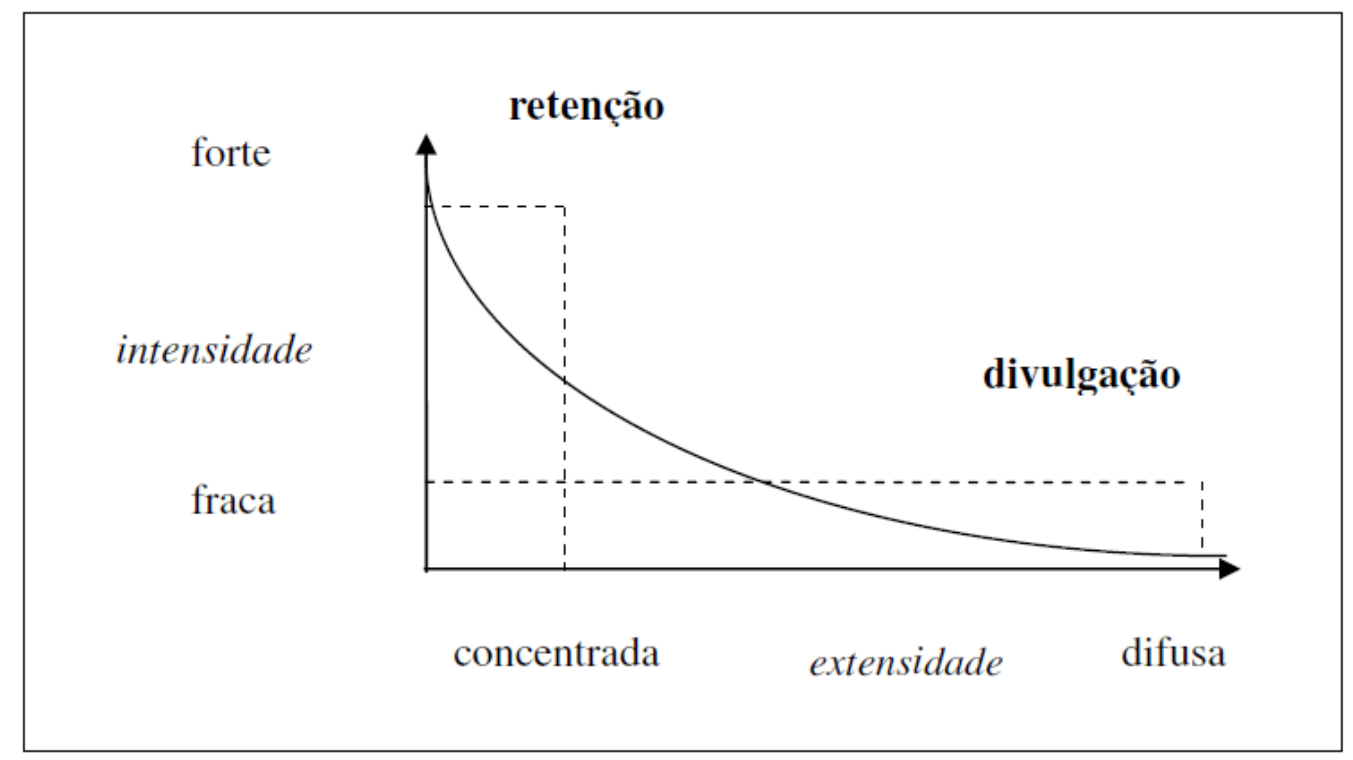

Figura 12. Esquema tensivo da divulgação (ZILBERBERG, 2007, p. 15)

Ao projetarmos o espaço tensivo (FONTANILLE e ZILBERBERG, 2001), mediante a correlação dos eixos da intensidade (eixo dos valores de absoluto, onde domina o foco) e da extensidade (eixo dos valores de universo, onde domina a apreensão), relacionando-os, conforme Zilberberg (2007, p. 15), aos estilos enunciativos de retenção e de divulgação temos: para o estilo retensivo, a pertinência da intensidade; para estilo da divulgação, a pertinência da extensidade.

Podemos verificar como a espacialidade figural é determinada nos discursos da totalidade de divulgação por uma perspectiva do extenso, de espacialidade difusora, ocupante; contrária a uma perspectiva do intenso, de espacialidade concentradora, circunscritiva, própria aos discursos pautados pela retórica da retenção.

Considerando, especificamente, a divulgação religiosa, verificamos que as crenças partilhadas por esse discurso são inseridas em uma natureza informativa. Observamos, nessa totalidade, portanto, a imbricação entre saberes de crenças e saberes de conhecimento. De acordo com Charaudeau (2006, p. 43-45), os saberes de conhecimento, pautados por um efeito de sentido de objetividade, são responsáveis pela construção de uma enunciação informativa, segundo a qual se procura realizar uma visão estruturada do mundo. Os saberes de crença seriam, em contrapartida, resultantes: 
da atividade humana quando esta se aplica a comentar o mundo, isto é, a fazer com que o mundo não exista mais por si mesmo, mas sim através do olhar subjetivo que o sujeito lança sobre ele. Uma tentativa não mais de inteligibilidade do mundo, mas de avaliação de sua legitimidade, e de apreciação quanto ao seu efeito sobre o homem e suas regras de vida (CHARAUDEAU, 2006, p. 45).

Esse olhar subjetivo corresponde ao imaginário de referência (ponto de vista) do enunciador, responsável pela justificativa de determinados comportamentos, como eufóricos ou disfóricos, dentro do quadro axiológico de uma determinada formação discursiva.

Há, na divulgação religiosa, portanto, uma imbricação entre as modalidades do crer e do saber concebidas, segundo Greimas (1983), como pertencentes a um mesmo universo cognitivo. A estruturação do saber a ser transmitido por esse discurso orienta-se consoante categorias de crença, enquanto regulação de práticas sociais e das normas efetivas de comportamento de uma determinada formação discursiva.

Verificamos, pois, como a divulgação religiosa se pauta tensivamente: as cifras tensivas das modalidades do crer, com o privilégio de valores emissivos (continuativos) e a conservação do objeto de valor. Essas modalidades estão associadas à modalidade do saber, caracterizada por valores remissivos (parada) (ZILBERBERG, 2006b).

O outro é interpelado para fazer com que esse "outro" compartilhe determinados julgamentos sobre o mundo (relação de cumplicidade), após a realização do julgamento epistêmico e posterior tomada de posição em relação à avaliação proposta ${ }^{52}$ (CHARAUDEAU, 2006, p.46).

Os discursos de divulgação religiosa caracterizam-se como um fazer interpretativo sobre um discurso primeiro, entendido, de acordo com Orlandi (2003), como discurso fundador. Assim sendo, dadas as interpretações suscitadas pela Bíblia, vista como discurso fundador do discurso de divulgação religiosa, podemos, a partir das afirmações de Panier (1986), distinguir o discurso de divulgação religiosa sob a noção do discurso-comentário, na medida em que este, ao caracterizar-se como um texto de interpretação do relato bíblico, pode ser definido como um discurso segundo "produzido a partir de um primeiro discurso, e que se apresenta como equivalente do ponto de vista do sentido" (PANIER, 1986, p. 267).

\footnotetext{
52 "Na medida em que no interior do contrato enunciativo (implícito ou explícito) o enunciador exerce uma fazer interpretativo (isto é, um fazer-crer), o enunciatário, por sua vez, finaliza o seu fazer interpretativo por um juízo epistêmico (isto é, por um crer) que ele emite sobre os enunciados de estado que lhe são atribuídos" (GREIMAS; COURTÉS, 2008, p. 172).
} 
Fiorin (1988) revê a noção de discurso-comentário, mediante a proposição do discurso teológico ou militante. Conforme o autor, "o discurso religioso teológico ou militante é um discurso interpretativo sobre um discurso primeiro, explicitamente assumido, que constitui seu referente" (FIORIN, 1988, p. 142).

Maingueneau (2005a, p. 29) traz o conceito de discurso-comentário segundo a designação de "discurso devoto". Para esse autor, os discursos devotos possuem uma característica doutrinária própria, "se entendemos por isso enunciados cuja finalidade é menos especulativa do que prática: ensinar aos fiéis quais são os comportamentos que eles devem adotar para viver cristãmente em uma sociedade determinada" (MAINGUENEAU, 2005a, p. 29).

Tomando como base as reflexões anteriores, propomos uma definição a respeito do que consideramos discurso de divulgação religiosa. Os discursos de divulgação religiosa operacionalizam duas categorias de performance: um fazer comunicativo ou persuasivo, no qual esse discurso opera com a transmissão de um saber que se pretende como a verdade (fazer-saber); um fazer interpretativo, segundo o qual ele interpreta a narrativa fundadora que toma por objeto. Esse fazer interpretativo deve ser considerado como efeito de sentido produzido por esse discurso.

Desse modo, o discurso de divulgação religiosa constitui-se por meio de um procedimento parafrástico de função essencialmente alusiva. Pautado pela construção de simulacros, apresenta, na enunciação dos diversos gêneros envolvidos, uma função de reescritura e de interpretação do relato bíblico fundador. Esse discurso, servindo como mediador entre um arquidestinador divino superior e aqueles destinatários a quem busca atingir (fiéis), por meio de um texto instrucional e propagador da doutrina das Sagradas Escrituras, possuindo, portanto, como arquiobjeto (objeto-valor ${ }^{53}$ ), a graça divina, apoia-se em uma manipulação enunciativa para que o leitor (actante coletivo), tendo sido persuadido para que aderisse ao objeto modal "saber", orientado para um "dever-saber" e, por conseguinte, deonticamente modalizado, queira aprender os fundamentos bíblicos em conformidade com a ideologia que os fundamenta.

53 "O objeto - ou o objeto-valor - define-se, então, como lugar de investimento de valores (ou das determinações) com as quais o sujeito está em conjunção ou em disjunção" (GREIMAS; COURTÉS, 2008, p. 347). 


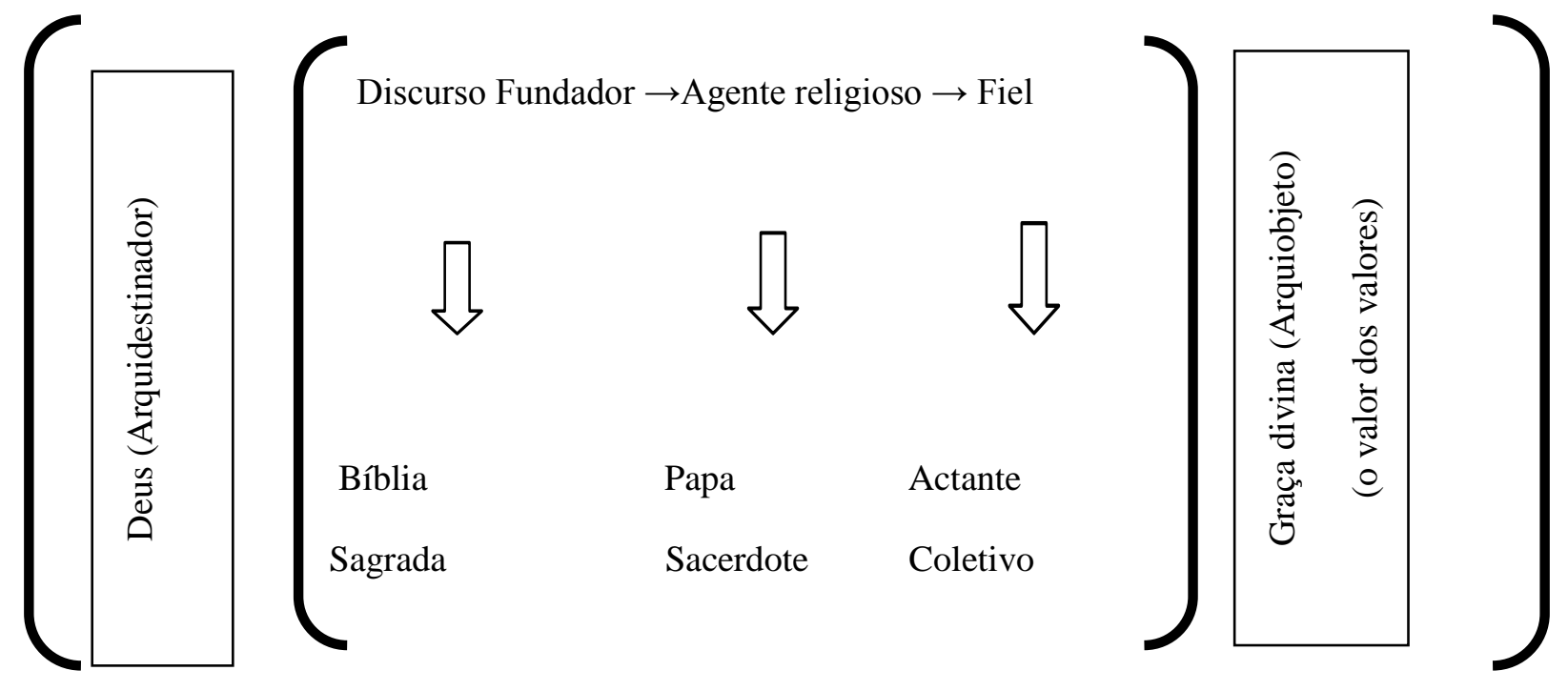

Figura 13. Dimensão cognitiva do discurso de divulgação: posição de ambivalência do agente religioso.

Percebemos, assim, mediante a observação da esquematização anterior, como o agente religioso (enquanto autoridade instituída pela formação discursiva considerada) ocupa, na totalidade de divulgação, um lugar de ambivalência: é ao mesmo tempo destinatário do arquidestinador divino e destinador em relação ao fiel. Desse modo, dentro dessa perspectiva, quando dizemos "que a voz de Deus se fala no padre, é "como se" Deus falasse: a voz do padre é a voz de Deus" (ORLANDI, 1996, p. 244).

O discurso religioso de divulgação, ao operacionalizar a dimensão cognitiva, apresenta ao homem um programa de ação por meio da execução de um fazer persuasivo, ou seja, da proposição de um dever-fazer ao destinatário. Temos, portanto, um sistema de modalidades deônticas com a instalação de prescrições (dever-fazer) e de interdições (dever não fazer).

Poder e saber são dispostos assimetricamente entre enunciador e enunciatário. O enunciador, caracterizado por intermédio de uma operação fiduciária sobredeterminada pelo crer, procura persuadir o enunciatário por meio de manipulações, nas quais são propostas, ao mesmo tempo, tentações e intimidações.

Nesse discurso, o efeito de sentido de paroxismo autoritário fica na ordem do segredo: é autoritário, mas não parece.

O representante de Deus, ao se apropriar da palavra divina, o faz sem autonomia alguma. A voz de Deus se coloca como a voz do enunciador primeiro, onipotente e onisciente, cujo enunciado, ao lembrar os atributos divinos, configura-se por meio da modalidade 
epistêmica da certeza (crer-ser), devido à ausência de quaisquer elementos modais que possam levantar incerteza (não crer ser).

O sujeito divulgador, ao aceitar ser deonticamente modalizado pelo discurso fundador, apresenta um julgamento ético sobre os enunciados primeiros. Esse julgamento se refere às estruturas modais éticas que modalizam os enunciados. "Compreende-se que haveria duas estruturas modais éticas, uma em que o /crer/ sobredetermina um /dever-fazer/ e outra em que ele sobredetermina um /poder fazer/" (GREIMAS; COURTÉS, 1986, p. 143). Assim, após o julgamento ético efetuado, o sujeito divulgador adquire um crer dever fazer (engajamento) e um crer poder fazer (competência).

Os discursos da totalidade de divulgação religiosa pertencem a uma esfera de circulação do sentido, a que se pressupõe o "fazer-saber", ou seja, a dimensão da doação de um objeto de valor cognitivo, que é o "saber das coisas de Deus", dado como objeto desejável e possível, e tem como preocupação encadear injunções e ensinamentos, direta ou indiretamente. Dessa forma, os textos da totalidade considerada se agrupam segundo elementos extensos para fundar a práxis da divulgação da fé religiosa. Para isso, o andamento tende, assim como o estilo, em princípio, a apresentar marcas de desaceleração.

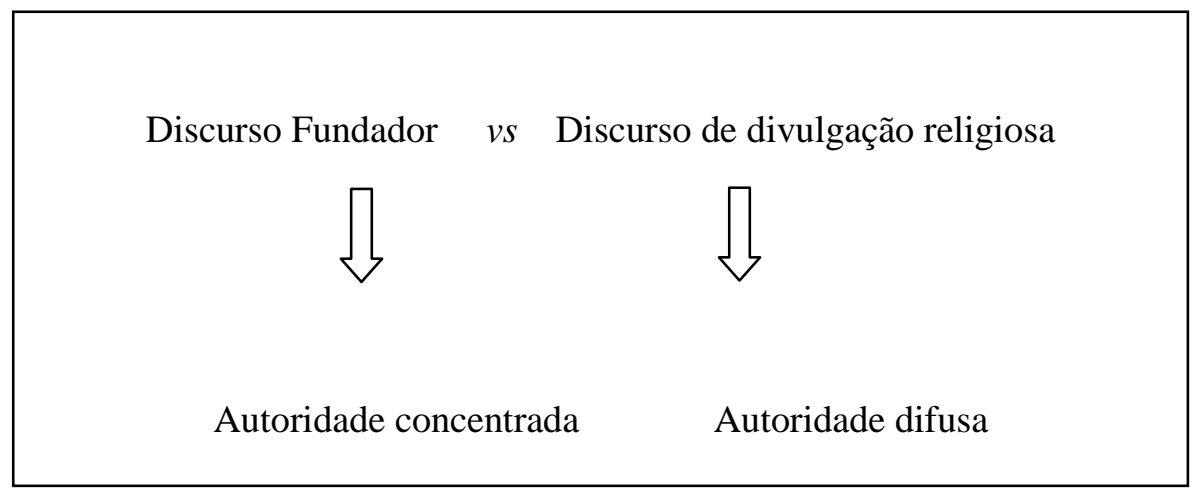

Figura 14. Práxis da divulgação da fé religiosa.

Contrariamente ao discurso fundador, pautado por um sujeito determinado segundo a concentração, há, no discurso de divulgação religiosa, um sujeito determinado segundo a expansão. Essa expansão se verifica pelo preenchimento de lacunas semânticas, com o estabelecimento de fronteiras traçadas para o fiel. Este tem de ser orientado e ensinado: é necessário que se privilegie o contínuo, para que a previsibilidade o sustente com segurança.

Por meio dessa lentidão, espera-se encontrar a imagem do sujeito, determinada nos textos que materializam a divulgação religiosa. 
Procedemos, assim, à análise do éthos característico do ator da enunciação da divulgação religiosa. Delineamos, pois, o ator da enunciação definido pela totalidade dos discursos de divulgação religiosa. Diante disso, além da persuasão por argumentos, observamos como se processa, na totalidade de divulgação religiosa, a constituição de um corpo, enquanto imagem igualitária daqueles que aderem a um mesmo posicionamento discursivo.

Dessa maneira, a descrição dos mecanismos de construção do sentido nos enunciados enfeixados pelo discurso religioso e sua divulgação, e que entendemos como cenas enunciativas complementares entre si, permite-nos compreender a instituição de um pacto fiduciário diferenciado no que corresponde à socialização do conhecimento. O preenchimento semântico dos lugares enunciativos do enunciador e do enunciatário apresenta variações no papel temático e figurativo na passagem da cena enunciativa do discurso religioso fundador para a cena enunciativa do discurso de divulgação religiosa. Isso nos leva a entender por que o discurso religioso de divulgação, de maneira distinta do discurso religioso fundador, institui a veridicção e a fidúcia segundo o proselitismo.

\section{Tipologia dos discursos de divulgação religiosa}

Uma das tarefas essenciais da análise do discurso é a de classificar os discursos que são produzidos numa sociedade. Aliás, os membros de uma coletividade têm uma competência, em matéria de tipologia dos discursos, que lhes permite reconhecer o tipo de atividade discursiva na qual eles estão engajados e, daí comportar-se de maneira apropriada.

Dominique Maingueneau ${ }^{54}$

Entendemos haver uma função referencial ${ }^{55}$ de natureza extensiva, própria aos discursos de divulgação. De acordo com Maingueneu (2008a), o discurso religioso encarna, por sua própria enunciação, o que ele prescreve. Temos, assim, o conteúdo indissociável do éthos do corpo enunciante próprio a essa totalidade de discursos. A partir disso, podemos

\footnotetext{
${ }^{54}$ Maingueneau (2006, p. 143).

55 "Função referencial é a função cognitiva ou denotativa através da qual o referente da mensagem é considerado como o elemento mais importante" (DUBOIS, 2001, p.512).
} 
delinear uma tipologia de tais discursos. Para que possamos elaborá-la, remetemo-nos à análise do discurso (AD), que tem, como uma de suas tarefas essenciais, a classificação dos discursos produzidos em sociedade (CHARAUDEAU; MAINGUENEAU, 2004, p. 468).

Para a organização dessa tipologia, tomamos como base o estudo de Grillo (2006a), concernente ao discurso de divulgação científica, ao estabelecer três campos distintos em que a divulgação científica pode ocorrer: a) campo científico (público-alvo mais restrito, especializado); b) campo educacional (instrucional); c) campo de informação midiática (público-alvo mais amplo).

Procuramos, assim, fundamentados na proposição de Grillo (Idem), formular uma tipologia do discurso de divulgação religiosa, tendo, por princípio, o estabelecimento de cinco cenas enunciativas diferenciadas: a) divulgação religiosa especializada; b) divulgação religiosa instrucional; c) divulgação para conscientização social; d) divulgação religiosa propagandista; e) divulgação religiosa midiática. Como critério diferenciador, propomos uma tipologia calcada no enunciatário.

A própria noção de divulgação apresenta influência do destinatário (público-alvo presumido) na maneira como o enunciado estrutura-se composicional e estilisticamente. Essa influência é resultado de uma cointencionalidade entre os efeitos visados, os efeitos possíveis e os efeitos produzidos a fim de atingir a afetividade do destinatário (CHARAUDEAU, 2006, p.28).

O eu e o tu são os actantes da enunciação, os participantes da cena enunciativa. Ambos constituem o sujeito da enunciação, porque o primeiro produz o enunciado e o segundo, funcionando como uma espécie de filtro, é levado em consideração pelo eu na construção do enunciado (FIORIN, 2004, p. 117).

A observação das recorrências no conjunto de textos que compõe a materialidade discursiva da totalidade de divulgação, recortada para fins de análise, permitiu-nos reconhecer e isolar metodologicamente os diferentes níveis hierárquicos em que a divulgação se realiza e que compõem as cinco cenas enunciativas em análise. 
a) Divulgação religiosa especializada

A divulgação religiosa especializada concretiza-se no campo religioso; tem como público-alvo os pares que partilham dos mesmos valores de uma determinada formação discursiva e, como enunciador, um porta voz autorizado (agente de prestígio), sobretudo, o papa. Ex.: gênero encíclica católica.

b) Divulgação religiosa instrucional

Falaremos aqui de uma espacialização enunciativa, de lugares enunciativos, estabelecidos no eixo alto/baixo, na ordem da verticalidade. A divulgação religiosa instrucional, presente no campo educacional religioso, apresenta, então, uma espacialização característica, que, organizada ao redor da instância do "aqui", constrói o simulacro da cena de doação de saber. Tomemos como um dos critérios subjacentes a essa cena enunciativa, a noção de reversibilidade. De acordo com Orlandi (1996, p. 239), podemos entender a noção de reversibilidade "como a troca de papéis na interação que constitui o discurso e que o discurso constitui". Observamos, assim, que o enunciado divulgador da cena de divulgação instrucional constrói uma da ilusão de reversibilidade, com a definição hierárquica dos lugares enunciativos do arquidestinador (Deus), do mestre (destinador mediador e, portanto, divulgador da Palavra Divina absoluta) e do discípulo (destinatário e receptor do saber religioso). Temos, por conseguinte, uma espacialização discursiva determinada pela direção superativa no eixo da verticalidade, a fim de que o destinatário (fiel) estabeleça o "alto" como categoria, para que desse modo seja possível retomar o seu encontro com Deus.

Logo, vemos emergir, nos discursos de divulgação religiosa, um tom de "orientação" determinado por uma voz que define o estabelecimento de dois lugares enunciativos: o mestre (aquele que sabe e deve transmitir o conhecimento) e o discípulo (aquele que deve aprender).

A lentidão, própria aos discursos de divulgação religiosa de caráter instrucional, corresponde à preocupação com a previsibilidade apresentada por esses discursos. O caráter de ensinamento, particular aos discursos de divulgação, pode ser associado, nesse sentido, à lentidão e desaceleração características. Ex: gênero compêndio; livros instrucionais. 
c) Divulgação para conscientização social

Tomamos como divulgação para conscientização social aqueles discursos produzidos com o intuito de se inserir em determinadas atividades de evangelização desenvolvidas pela esfera ideológica católica. Dentre essas atividades, podemos citar a campanha da fraternidade (CF), desenvolvida no período da Quaresma. Essa campanha tem como critérios para escolha de temas aspectos da vida da Igreja e da sociedade brasileira contemporânea.

d) Divulgação religiosa propagandista

Para corroborar a distinção entre divulgação religiosa instrucional (educacional) e divulgação religiosa para conversão (propagandista), tomemos como base a correlação entre educador vs. propagandista, definida por Perelman; Olbrechts-Tyteca (2005, p.57-58):

o educador difere essencialmente do propagandista porque seu tema versa sobre matérias que não são, para seu auditório, objeto de controvérsia. $\mathrm{O}$ padre católico que ensina os preceitos de sua religião a crianças católicas de sua paróquia cumpre um papel de educador, ao passo que é propagandista e se dirige com o mesmo intento, aos adultos membros de outro grupo religioso. Mas em nossa opinião há mais. Enquanto o propagandista deve grangear, previamente, a audiência do seu público, o educador foi encarregado por uma comunidade de tornar-se o porta-voz dos valores reconhecidos por ela e, como tal, usufrui um prestígio devido a suas funções.

Na divulgação religiosa propagandista (conversão), o sujeito é manipulado a realizar a parada da própria parada. Trazemos aqui valores tensivos, mediante a proposição de uma tensivização da narratividade. Expliquemos: a parada corresponde, tensivamente, a sua incidência sobre uma relação anterior de continuidade. Teríamos, assim, a parada de uma situação anterior de relaxamento na qual o sujeito estaria conjunto com uma determinada formação religiosa, cumprindo a realização dos programas narrativos propostos. À parada da continuação sucede a duração da parada (continuação da parada). A esta segue o momento tensivo traduzido sintaxicamente como "parada da parada" (TATIT, 2001, p.177). O sujeito passa por toda essa sequência, ao atingir na parada da parada, as condições tensivas do programa de manipulação dessa nova formação discursiva, que procura integrá-lo a um novo sistema de valores. Temos, portanto, a determinação de uma nova continuidade (relaxamento) concedida por meio da adesão do sujeito e posterior sanção cognitiva que integra o cristão, em 
relação desejada com o $\mathrm{O}_{\mathrm{v}}$ "graça divina" dessa nova formação discursiva. Ex. compêndio didático de estudo bíblico (Testemunha de Jeová, doravante TJ), tratados (folhetos) de estudo bíblico.

e) Divulgação religiosa midiática

A divulgação religiosa midiática, presente no campo religioso de informação midiática, possui as mesmas características que o discurso científico da esfera midiática, sendo submetida às próprias coerções do campo midiático: contemporaneidade; peculiar efeito de "objetividade"; efeito de sentido de duplicação do real; referencialidade exaltada; compromisso com a veridicção; argumento de autoridade; uso de atores detentores de legitimidade social para afirmação de determinados valores propugnados pela formação religiosa considerada; heterogeneidade mostrada e marcada (AUTHIER-REVUZ, 1982), como aspas e glosas do enunciador; informatividade acentuada (interlocução jornalística); suposta adesão do leitor a certa posição discursiva.

Afirma Martino (2003, p. 19) que podemos distinguir a grande imprensa (mídia generalista) da mídia institucional religiosa, a que denominamos de discurso de divulgação religiosa midiática. Para o autor essa distinção seria realizada por meio da distinção entre os objetos de valor almejados por cada uma delas. Enquanto, para a grande imprensa, o produto final (objeto de valor) é a informação dada enquanto valor mercadológico, para a divulgação religiosa, a informação seria o veículo para a obtenção de bens de outra natureza: os bens de salvação.

Verificamos o uso dos meios de comunicação de massa que têm a finalidade de divulgar a "Boa Nova", ou seja, o produto veiculado pela mídia institucional religiosa: o anúncio da Salvação. Esse anúncio corresponde à missão de evangelização da Igreja responsável pelo anúncio da "Boa Nova" [evangelho, discurso fundador] "a todos os homens, de qualquer país e de qualquer meio, para transformá-los, a partir de dentro, e assim tornar nova a própria humanidade" (CARDEAL ARNS, 1981, p. 27).

Vejamos como a utilização dos "mass media" no processo de evangelização aparece fundamentada em um importante documento pontifício católico, a carta encíclica Evangelii Nuntiandi: 
Postos a serviço do Evangelho, tais meios são suscetíveis de ampliar, quase até o infinito, o campo para poder ser ouvida a Palavra de Deus e fazem com que a Boa Nova chegue a milhões de pessoas. A Igreja viria a sentir-se culpável diante do seu Senhor, se não lançasse mão destes meios potentes que a inteligência humana torna a cada dia mais aperfeiçoados (PAULO VI, 2009, p. 53).

De nossa parte, consideramos essa perspectiva tipológica como um conjunto simbólico distribuído via mídia, mediante uma explícita imposição doutrinária, mascarada pela aparência de objetividade informativa e pela "indiscutibilidade" do real (MARTINO, 2003, p.9). Esse efeito de sentido de objetividade encobre a verdadeira seleção temática e lexical presente no discurso de uma formação discursiva considerada. O estilo subsume tais seleções (DISCINI, 2004b).

A cena enunciativa midiática apresenta um público-alvo mais restrito, por ter seu meio de difusão (artigos jornalísticos e entrevistas em revistas e jornais de divulgação religiosa especializada) realizado, sobretudo, por meio de assinaturas ou vendas em livrarias religiosas específicas, tais como Paulinas, Paulus, Loyola etc. Podemos citar também a televisão, que ultimamente vem se expandindo como um importante meio de divulgação religiosa, de amplitude e público maiores do que o das revistas e jornais especializados.

\section{Análise dos enunciados de divulgação religiosa}

\subsection{Divulgação religiosa especializada}

O sucessor de Pedro é assim, pela vontade de Cristo, encarregado do ministério preeminente de ensinar a verdade revelada. [...] $\mathrm{O}$ poder pleno, supremo e universal que Cristo confia ao seu Vigário para o governo pastoral da sua Igreja, acha-se, portanto, de modo especial na atividade de pregar e de mandar pregar a Boa Nova da Salvação, que o Papa exerce.

Papa Paulo VI ${ }^{56}$

Entendemos por encíclica o enunciado caracterizado como uma carta circular de autoria do Romano Pontífice, para exercer seu magistério ordinário. Dirige-se diretamente aos

${ }^{56}$ PAULO VI (2009, p. 85-86). 
bispos e por meio deles aos fiéis da Igreja Católica (leigos) e às pessoas ditas de boa vontade. A encíclica tem, por temática, assuntos da doutrina católica, pertencentes a campos diversos: fé, costumes, culto, doutrina social, entre outros ${ }^{57}$. Nelas, o Papa expõe sua posição a respeito de diversas questões que envolvam fé e moral. Procuramos observar como se constitui o estilo nos enunciados de divulgação especializada. Para estabelecer totalidades, procedemos ao recorte dos seguintes enunciados: Carta Encíclica Evangelium Vitae; Carta Encíclica "Deus Caritas Est". Nossa concepção de estilo é esta: o "estilo como modo próprio de dizer de uma enunciação única, depreensível de uma totalidade enunciada" (DISCINI, 2004b, p. 17). Cada uma dessas encíclicas é um unus, que remete a um totus, o conjunto de enunciados que compõe a divulgação religiosa especializada. Como o todo está nas partes, optamos por realizar dentro desse corpus, a análise semiótica, abarcando todos os níveis, de apenas um desses enunciados: Carta Encíclica "Deus Caritas Est". Concebemos, assim, com apoio em Discini (Idem), o percurso gerativo do sentido como ferramenta necessária a depreensão do estilo de uma totalidade de discursos enunciados. Para essa análise, isolamos duas unidades da encíclica Evangelium Vitae: Introdução e Capítulo I. O capítulo se apresenta com este título: A voz do sangue do teu irmão clama da terra até mim. Partindo da ideia de que cada unidade (unus) pressupõe a totalidade (totus) em que está inserida, realizamos, por meio da análise semiótica de excertos extraídos dessas unidades, a depreensão do estilo da totalidade da encíclica católica. Em seguida, procuraremos delimitar as recorrências na materialidade discursiva da totalidade e os procedimentos argumentativos que determinam o éthos do sujeito divulgador católico e que constituem a cena enunciativa de divulgação religiosa especializada.

São estes os enunciados de divulgação especializada que recortamos para análise:

\footnotetext{
${ }^{57}$ Segundo Calvez (1995, p. 12), não se deve conceber a palavra "doutrina” em seu "sentido forte, próximo do dogma, mas antes, precisamente no sentido de ensinamento, especificamente ensinamento moral, que se distingue do dogma por mais de um aspecto, nem que seja pela frequente referência a situações contingentes". Dessa forma, o autor se considera levado a julgar a correspondência entre "ensinamento social" com ensinamento como recomendação prática". Ensinamento social designaria "ao mesmo tempo, a mensagem evangélica, suas exigências gerais, e as conclusões ou recomendações mais particulares”.
} 
a) Carta Encíclica Evangelium Vitae: documento pontifício da Igreja Católica (IC) emitido pelo Papa João Paulo II, em 25 de março de 1995 (T8 ${ }^{58}$ ). O conteúdo temático do texto referido se volta, predominantemente, à questão da defesa da vida humana e à polêmica motivada pelas práticas atuais de disseminação do aborto, da eutanásia e das pesquisas envolvendo células-tronco embrionárias. Verificamos a divisão do enunciado da encíclica em quatro capítulos, a seguir: Capítulo. I - a voz do sangue do teu irmão clama da terra até mim; Capítulo. II - Vim para que tenham vida; Capítulo III - Não matarás; Capítulo IV. A mim o fizestes.

b) Carta Encíclica "Deus Caritas Est": documento promulgado pelo sumo pontífice Bento XVI, em 25 de dezembro de 2005. O conteúdo temático do texto referido se concentra na concepção e prática do amor na Sagrada Escritura e na Tradição da Igreja, sem prescindir da dimensão que esse conceito tem nas diversas culturas e na linguagem contemporânea. Ainda no que diz respeito à temática do referido texto, vemos que o enunciado se compõe de duas partes: i) a primeira, de índole mais especulativa, procura especificar "alguns dados essenciais sobre o amor que Deus oferece de modo misterioso e gratuito ao homem, juntamente com o nexo intrínseco daquele amor como realidade do ser humano" (BENTO XVI, 2008, p. 4); ii) a segunda, de caráter prático, trata do serviço da caridade, concebido como atividade da Igreja enquanto manifestação do amor. O texto estrutura-se composionalmente por meio de uma divisão em parágrafos indicados por números. Verificamos, por conseguinte, a presença do raciocínio argumentativo e implicativo na exposição das duas partes das quais se compõe a encíclica. Branco (2009, p. 168) refere-se à surpresa suscitada pelo lançamento da referida encíclica, em janeiro de 2006, no que diz respeito à temática escolhida: o amor. Segundo a autora (Idem, ibidem), Bento XVI já teria, por princípio, a resposta a uma imagem anterior "fria e dura" que se fazia dele, em oposição ao seu "carismático antecessor, João Paulo II". Seria possível, tal como pergunta a autora, que a própria escolha da concepção de amor como tema da encíclica fosse uma resposta a essa imagem que se fazia dele, já que o amor sensibiliza as pessoas? Embora a escolha da temática seja determinante, acreditamos que a força argumentativa empregada, bem como as marcas deixadas no enunciado e que remontam

\footnotetext{
${ }^{58}$ Levando em conta que o suporte também é determinante para a depreensão do sentido do texto, reproduzimos os artigos na seção anexos. As indicações "T" seguidas do referido número correspondem à numeração dos textos em análise e que se encontram no volume II, anexos, desta tese.
} 
a essa imagem de si sejam mais determinantes para a caracterização desse éthos benevolente que se propõe construir.

\subsubsection{Análise semiótica da encíclica Evangelium Vitae}

Como se realiza o fazer interpretativo do próprio enunciador, ora definido pelo papel daquele que interpreta a narrativa bíblica de Gênesis (Gn 4, 1-16) como discurso fundador? Como se processa a passagem do discurso figurativo bíblico para o discurso não figurativo, que toma a narrativa bíblica de Caim e Abel como discurso fundador, na raiz da violência contra a vida? Como a escolha dos recursos relativos à gramática da língua reflete na incorporação de um éthos, com entonação expressiva peculiar? Mediante quais recursos discursivos configura-se o posicionamento do sujeito, como aquele que é contrário às ameaças à vida humana enfrentadas pela sociedade contemporânea? Essas são algumas das questões que procuramos elucidar por meio da análise proposta.

Tomemos como base os seguintes segmentos, pertencentes à carta encíclica Evangelium Vitae, e dos quais procederemos à análise a seguir.

(I) A Igreja sabe que este Evangelho da vida, recebido do seu Senhor, encontra um eco profundo e persuasivo no coração de cada pessoa, crente e até não crente, porque se ele supera infinitamente as suas aspirações, também lhes corresponde de maneira admirável. Mesmo por entre dificuldades e incertezas, todo o homem sinceramente aberto à verdade $\mathrm{e}$ ao bem pode, pela luz da razão e com o secreto influxo da graça, chegar a reconhecer, na lei natural inscrita no coração (cf. $R m$ 2, 14-15), o valor sagrado da vida humana desde o seu início até ao seu termo, e afirmar o direito que todo o ser humano tem de ver plenamente respeitado este seu bem primário. Sobre o reconhecimento de tal direito é que se funda a convivência humana e a própria comunidade política (JOAO PAULO II, 2005, p.7).

(II) Já o Concílio Vaticano II, numa página de dramática atualidade, deplorou fortemente os múltiplos crimes e atentados contra a vida humana. À distância de trinta anos e fazendo minhas as palavras da Assembleia Conciliar, uma vez mais e com idêntica força os deploro em nome da Igreja inteira, com a certeza de interpretar o sentimento autêntico de toda a reta consciência: "Tudo quanto se opõe à vida, como seja toda a espécie de homicídio, genocídio, aborto, eutanásia e suicídio voluntário; tudo o que viola a integridade da pessoa humana, como as mutilações, os tormentos corporais e mentais e as tentativas para violentar as próprias consciências; tudo quanto ofende a dignidade da pessoa humana, como as condições de vida infra-humanas, as prisões arbitrárias, as deportações, a escravidão, a prostituição, o comércio de mulheres e jovens; e também as condições degradantes de trabalho, em que os operários são tratados como meros instrumentos de lucro e não como pessoas livres e responsáveis. Todas estas coisas e outras semelhantes são infamantes; ao mesmo tempo que corrompem a civilização humana, desonram mais aqueles que assim procedem, do que os que padecem 
injustamente; e ofendem gravemente a honra devida ao Criador" (JOAO PAULO II, 2005, p. 9-10).

A “cultura da morte", representada pelo domínio das pulsões individuais, realiza-se no enunciado pela exposição dos atentados contra a vida nascente e em seu término. Dentre esses atentados, destacamos, no texto, as práticas de difusão do aborto e da eutanásia. O "evangelho da vida" é representado pelos valores propostos pelo domínio religioso católico de defesa da vida em seus dois momentos principais: dignidade da criança ainda não nascida e dignidade da pessoa em fase terminal. Dessa maneira, a "defesa da vida" é euforizada axiologicamente e a "cultura da morte" é axiologizada disforicamene. Esse modo específico de axiologizar valores corresponde aos preceitos de uma determinada formação ideológica, no caso, os valores propugnados pela ideologia religiosa católica e que serão materializados no nível discursivo do percurso gerativo do sentido.

Para Greimas (2004, p.14), "toda religião é uma axiologia, isto é, um sistema conforme o qual se afirmam ou se negam certos valores: é, antes de mais nada, um sistema abstrato e conceitual".

Tomemos o seguinte gráfico a fim de que tornemos visualmente claras as relações narrativas a serem desenvolvidas a seguir:

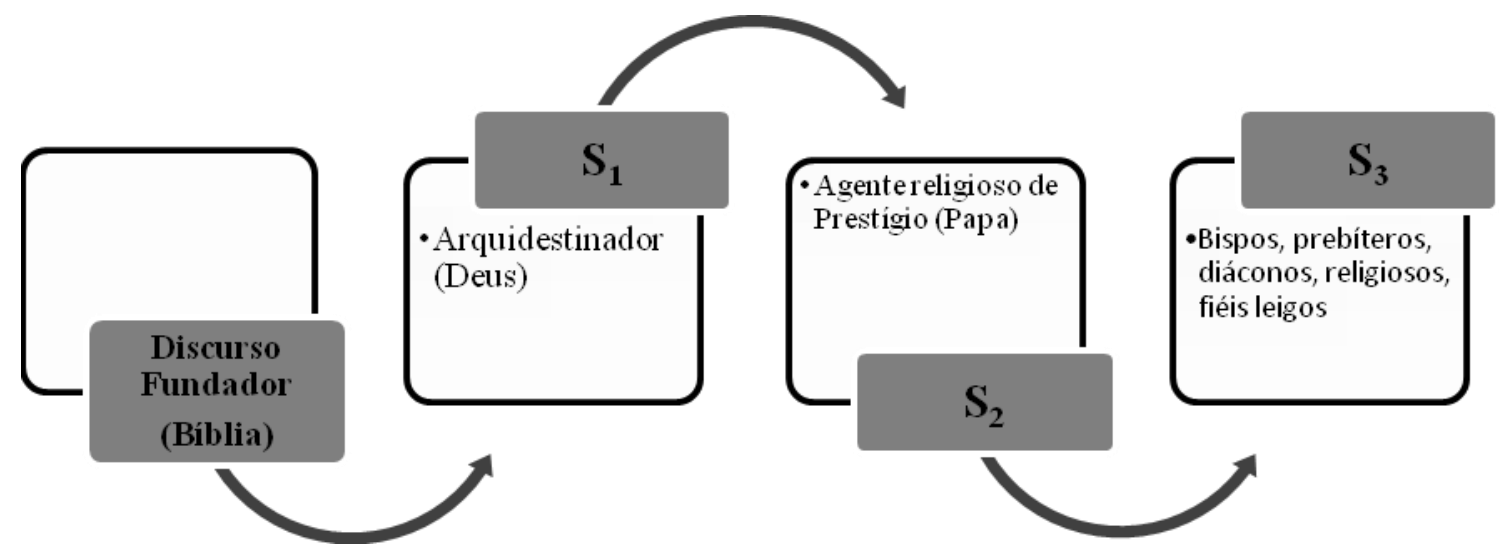

Figura 15. Discurso de divulgação religiosa: a encíclica Papal como narrativa de comentário.

Observamos, por meio da $\mathrm{SN}_{1}$ (sequência narrativa do enunciado), o Sujeito $\mathrm{S}_{2}$ (agente religioso de prestígio "Papa") e destinatário do arquidestinador divino $\mathrm{S}_{1}$ (arquidestinador 
divino) fazendo com que $S_{3}$ (bispos, presbíteros, diáconos, religiosos e religiosas, fiéis leigos e todas as pessoas ditas de boa vontade) permaneça em conjunção com o $\mathrm{O}_{\mathrm{v}}$ "destino de vida plena e perfeita". Por intermédio de um PN de aquisição de competência pressuposto, poder e saber são atribuídos ao homem para dominar o pecado e agir conforme os preceitos divinos. $\mathrm{O}$ homem, tal como na narrativa fundadora, tem as modalidades do saber-fazer, dever-fazer e poder-fazer necessárias para dominar o pecado. A performance não se realiza, o sujeito é manipulado por tentação pelo antiprograma narrativo desenvolvido pelo demônio. $\mathrm{O}$ antidestinador, figurativizado pelo demônio, interrompe o fluxo fórico proposto, ao introduzir a experiência dilacerante da morte, o que ocasiona a parada da continuidade projetada por Deus, no enunciado em análise. A experiência dilacerante da morte, introduzida pelo demônio com o primeiro fratricídio (narrativa de Caim e Abel), realiza-se na narrativa de comentário pela performance da realização de atentados contra a vida humana. Desenvolve-se, assim, a narrativa de busca pelo restabelecimento da ligação entre o homem e Deus, possível pela redenção promovida pelo "sangue de Cristo", ao propor uma nova continuidade representada no enunciado por meio de "um novo caminho de amor, de acolhimento e de serviço à vida humana". Estabelece-se um PN de doação de competência, no qual o sangue de Cristo fornece o poder-ser e poder-fazer (força) necessários para que o homem possa empenhar-se em favor da vida.

É, enfim, do sangue de Cristo que todos os homens recebem a força para se empenharem a favor da vida. Precisamente esse sangue é o motivo mais forte da esperança, melhor, é o fundamento da certeza absoluta de que, segundo o desígnio de Deus, a vitória será a vida (JOAO PAULO II, 2005, p.53).

O sujeito da enunciação é considerado um sujeito realizador de um programa de construção de um objeto de valor cognitivo: a encíclica. Os valores católicos de defesa da vida, veiculados por esse objeto-discurso, são comunicados ao sujeito da enunciação (comentador) pelo destinador-manipulador (formação discursiva católica). O enunciador (agente de prestígio, Papa), dado o poder e autoridade de Pontífice Universal, como máxima autoridade da Igreja Católica, tem seu fazer reconhecido veridictoriamente: a exposição da matéria de fé e moral deve ser executada e praticada pelos membros da formação discursiva considerada.

Nesse discurso, a arquitetura do conhecimento não se institui como primordial, mas sim o ato perlocucional representado por meio do fazer-fazer, para que o sujeito possa agir de 
acordo com os preceitos da ordem religiosa considerada. Desse modo, a cenografia selecionada para análise confirma o gênero encíclica, com a exposição de prescrições a serem realizadas a fim de se atingir um determinado objetivo: a manutenção da comunhão com a comunidade da Igreja Católica.

A contemporaneidade do enunciado constitui-se a partir da utilização de uma temática de recente polêmica: a questão envolvendo os debates a respeito da liberação das práticas abortivas.

A palavra revelada (narrativa bíblica de "Caim e Abel"), ao ser citada na narrativa de comentário, é instituída como fonte e como fiadora desse discurso, legitimando o enunciado da encíclica. O próprio título da encíclica "Evangelium Vitae" em latim, língua da Igreja, confirma seu caráter de instrumento autorizado.

Por intermédio de um programa narrativo baseado em um contrato fiduciário, o destinador (Papa) busca convencer o destinatário-sujeito (bispos, presbíteros, religiosos e fiéis leigos, a quem a encíclica se dirige) mediante argumento de autoridade expresso pela referência à palavra divina.

A modalização deôntica apresenta um dever-fazer instaurado pelo destinador: dever agir como um leigo, um crente católico. Ao operar com a revelação dos saberes a respeito do conteúdo da fé católica, o discurso busca a adesão do destinatário por meio da manipulação executada pela modalização deôntica do dever-fazer (prescrição). $\mathrm{O}$ enunciador manipula o enunciatário para dever-saber e crer-poder-saber entrar em conjunção com os valores ideológicos propostos. Dessa forma, o modo próprio do enunciador desse discurso busca a adesão a sua imagem, adesão a ser desencadeada pelo enunciatário que deve partilhar das crenças e valores propostos.

No discurso de divulgação especializada, observamos a presença dos actantes: comentador (Romano Pontífice) e destinatário (fiel). O divulgador (Papa) deve realizar a intermediação entre o arquidestinador divino e os fiéis e a tradução de um discurso bíblico original, "ausente" de autoria "seu autor é apenas o representante inspirado de uma entidade sem rosto: Deus, a Razão, o Espírito” (MAINGUENEAU, 2008c, p. 203). O sujeito que busca a conversão é também um avaliador e, dessa forma, o fazer interpretativo do destinatário deve legitimar a comunidade da qual fazem parte o comentador e seu destinatário (MAINGUENEAU, 2008c, p. 204). 
Essa "tradução" da narrativa fundadora em narrativa de comentário é realizada segundo a seguinte hierarquia de actantes/ atores: 1) Nível superior (alto) - universo celeste: Deus; Espírito Santo; 2) Nível inferior: fiéis (leigos) $\rightarrow$ busca do $\mathrm{O}_{v}$ "salvação"; 3) Nível intermediário, superior aos fiéis: comentador (divulgador); fiador; mediador autorizado da palavra de Deus.

Situa-se, portanto, no nível intermediário, o comentador (agente de prestígio, Papa), sujeito dotado de competência prática (devoção) e de competência teórica (conhecimento da doutrina).

A narrativa fundadora, enquanto enunciado destacado, é uma unidade autônoma, completa; expressão de um pensamento transcendente, cujo sentido é explicitado e desdobrado pelo comentador/divulgador.

De acordo com Maingueneau (2008c, p. 208), a Bíblia apresenta um duplo funcionamento: a) conjunto de textos; b) reservatório de citações para os membros de uma sociedade. Por sua vez, o narrador da divulgação executa uma triagem de citações, na qual o comentário se utiliza da narrativa bíblica, incorporando-a aos valores da formação discursiva considerada.

Desse modo, para divulgar uma mensagem abstrata, espiritual e teórica, e se fazer compreender, o divulgador (Papa) utiliza-se de um suporte concreto da linguagem: o pensamento figurativo ou raciocínio figurativo.

Os papéis actanciais são assumidos na narrativa de comentário pelo divulgador (narrador/ comentador) e pelo leitor-intérprete (narratário), este, implícito. Desenvolve-se, assim, a performance principal operacionalizada por esse discurso: a consumação de um comentário informativo, mediante o qual o saber comunicado pela narrativa realiza-se como um objeto-modal e como um objeto-valor.

Ao considerarmos o comentário, de acordo com Panier (1986, p. 273), como a realização de um fazer interpretativo, procedemos, em seguida, à descrição semiótica de como se processa essa interpretação. Trataremos o comentário como a integração do motivo ${ }^{59}$ da narrativa de referência. A narrativa de comentário (discurso de divulgação religiosa) realiza o princípio de saturação narrativa, segundo o qual são criados novos papéis actanciais e

\footnotetext{
${ }^{59}$ Entendemos por motivo a "unidade de tipo figurativo, que possui [...] um sentido independente de sua significação funcional em relação ao conjunto da narrativa em que se encontra" (GREIMAS; COURTÉS, 2008, p. 323).
} 
sequências discursivas, que têm por objetivo preencher as lacunas do segmento citado (discurso fundador).

Tendo em vista que os papéis e as figuras da narrativa de referência acham-se retomados, no comentário, sob novas isotopias, a interpretação da narrativa é um efeito produzido pelo discurso e a recorrência de procedimentos permite prever a forma dessas interpretações.

Dessa maneira, podemos observar que o discurso de divulgação religiosa considerado, ao expor a narrativa bíblica, completa as sequências lacunares desse enunciado de referência. Verificamos, mediante o mecanismo argumentativo empreendido pelo narrador (comentador), a explicitação daquilo que a narrativa de referência, isto é, o discurso fundador bíblico, apenas coloca segundo o parecer, tal como constatamos no seguinte excerto:

\begin{abstract}
$8^{60}$. Caim está « muito irritado » e tem o rosto «transtornado », porque « o Senhor olhou favoravelmente para Abel e para a sua oferta » $(G n 4,4)$. O texto bíblico não revela o motivo pelo qual Deus preferiu o sacrifício de Abel ao de Caim; mas indica claramente que, mesmo preferindo a oferta de Abel, não interrompe o seu diálogo com Caim. Acautela-o, recordandolhe a sua liberdade frente ao mal: o homem não está de forma alguma predestinado para o mal. Certamente, à semelhança de Adão, ele é tentado pela força maléfica do pecado que, como um animal feroz, se agacha à porta do seu coração, à espera de lançar-se sobre a presa. Mas Caim permanece livre diante do pecado. Pode e deve dominá-lo: «Cuidado, pois ele tem muita inclinação para ti, mas deves dominá-lo » $(G n$ 4, 7) (JOAO PAULO II, 2005, p. 19-20).
\end{abstract}

Percebemos, por intermédio da análise do nível discursivo, como se processa no discurso divulgador a inscrição de sequências discursivas complementares, obtidas mediante a recategorização operada pelo comentário. Observa-se a atualização no discurso de divulgação religiosa do conteúdo implícito das Sagradas Escrituras (discurso fundador) à luz da problemática da contemporaneidade.

"As figuras lexemáticas da narrativa de referência são, pelo discurso de comentário, correlacionadas com as figuras das sequências complementares e compõem [...] papéis temáticos e figurativos próprios ao comentário" (PANIER, 1986, p. 276). Vejamos como se opera essa recategorização temática e figurativa.

A narrativa de divulgação (encíclica), bem como a narrativa bíblica de referência, apresenta a seguinte configuração temática: a busca pelo restabelecimento da ligação entre o homem e Deus. Entretanto, essa configuração é determinada por meio do seguinte

\footnotetext{
${ }^{60}$ A indicação numérica presente, ao longo das citações desta tese, refere-se à numeração dos parágrafos realizada no enunciado da encíclica.
} 
investimento temático: a) defesa da vida divina; b) anúncio da mensagem divina; c) missão redentora de Jesus; d) valor incomparável da vida humana; e) atentados contra a vida humana; f) oposição entre o Bem e o Mal; g) livre preferência de Deus pelos mais fracos e indefesos; h) nova integração divina (redenção divina).

Veremos, a seguir, como esses temas recebem investimento figurativo ao longo do enunciado. As figuras extraídas do enunciado da encíclica encontram-se destacadas.

a) Defesa da vida divina: "evangelho da vida"; "valor sagrado da vida humana desde o seu início até o seu termo".

O Evangelho da vida está no centro da mensagem de Jesus. (JOAO PAULO II, 2005, p. 5, grifos nossos).

b) Anúncio da mensagem divina: "boa nova"; "aurora da salvação".

Amorosamente acolhido cada dia pela Igreja, há de ser fiel e corajosamente anunciado como boa nova aos homens de todos os tempos e culturas. Na aurora da salvação, é proclamado como feliz notícia o nascimento de um menino: «Anuncio-vos uma grande alegria, que o será para todo o povo (JOAO PAULO II, 2005, p. 5, grifos nossos).

c) Missão redentora de Jesus: "missão redentora"; "Jesus"; "Filho"; "Espírito Santificador"; "vida nova e eterna"; "comunhão com o Pai".

Ao apresentar o núcleo central da sua missão redentora, Jesus diz: « Eu vim para que tenham vida, e a tenham em abundância » $(J o 10,10)$. Ele fala daquela vida «nova » e «eterna » que consiste na comunhão com o Pai, à qual todo o homem é gratuitamente chamado no Filho, por obra do Espírito Santificador. Mas é precisamente em tal «vida » que todos os aspectos e momentos da vida do homem adquirem pleno significado (JOAO PAULO II, 2005, p. 5-6, grifos nossos).

d) Valor incomparável da vida humana: "plenitude da vida"; "dom da vida divina"; "vocação sobrenatural"; "grandeza e valor precioso da vida humana"; "realidade sagrada".

2. O homem é chamado a uma plenitude de vida que se estende muito para além das dimensões da sua existência terrena, porque consiste na participação da própria vida de Deus. A sublimidade desta vocação sobrenatural revela a grandeza e o valor precioso da vida humana, inclusive já na sua fase temporal. Com efeito, a vida temporal é condição basilar, momento inicial e parte integrante do processo global e unitário da existência humana: um processo que, para além de toda a expectativa e merecimento, fica iluminado pela promessa e 
renovado pelo dom da vida divina, que alcançará a sua plena realização na eternidade (cf. 1 Jo 3, 1-2). Ao mesmo tempo, porém, o próprio chamamento sobrenatural sublinha a relatividade da vida terrena do homem e da mulher. Na verdade, esta vida não é realidade « última », mas " penúltima »; trata-se, em todo o caso, de uma realidade sagrada que nos é confiada para a guardarmos com sentido de responsabilidade e levarmos à perfeição no amor pelo dom de nós mesmos a Deus e aos irmãos (JOAO PAULO II, 2005, p. 6, grifos nossos).

e) Atentados contra a vida humana: "múltiplos crimes e atentados contra a vida humana"; "homicídio"; "genocídio"; "aborto"; "eutanásia"; "suicídio voluntário"; "mutilações"; "tormentos corporais e mentais"; "tentativas para violentar as próprias consciências"; "condições de vida infra-humanas"; "prisões arbitrárias"; "deportações"; "escravidão"; "prostituição"; "comércio de mulheres e jovens"; "condições degradantes de trabalho".

Já o Concílio Vaticano II, numa página de dramática atualidade, deplorou fortemente os múltiplos crimes e atentados contra a vida humana. À distância de trinta anos e fazendo minhas as palavras da Assembleia Conciliar, uma vez mais e com idêntica força os deploro em nome da Igreja inteira, com a certeza de interpretar o sentimento autêntico de toda a reta consciência: «Tudo quanto se opõe à vida, como seja toda a espécie de homicídio, genocídio, aborto, eutanásia e suicídio voluntário; tudo o que viola a integridade da pessoa humana, como as mutilações, os tormentos corporais e mentais e as tentativas para violentar as próprias consciências; tudo quanto ofende a dignidade da pessoa humana, como as condições de vida infra-humanas, as prisões arbitrárias, as deportações, a escravidão, a prostituição, o comércio de mulheres e jovens; e também as condições degradantes de trabalho, em que os operários são tratados como meros instrumentos de lucro e não como pessoas livres e responsáveis. Todas estas coisas e outras semelhantes são infamantes; ao mesmo tempo que corrompem a civilização humana, desonram mais aqueles que assim procedem, do que os que padecem injustamente; e ofendem gravemente a honra devida ao Criador » (JOAO PAULO II, 2005, p. 9-10, grifos nossos).

f) Oposição entre o Bem e o Mal: "defesa e cuidado da vida humana"; "atos contra a pessoa"; "soluções falsas e ilusórias"; "verdade e o bem das pessoas e das nações"; "comportamentos contrários à vida"; "cultura da morte"; "estruturas de pecado"; "vida"; " confusão entre o bem e o mal"; "fundamental direito à vida".

A própria medicina que, por vocação, se orienta para a defesa e cuidado da vida humana, em alguns dos seus setores vai-se prestando em escala cada vez maior a realizar tais atos contra a pessoa, e, deste modo, deforma o seu rosto, contradiz-se a si mesma e humilha a dignidade de quantos a exercem. Em semelhante contexto cultural e legal, os graves problemas demográficos, sociais ou familiares - que incidem sobre numerosos povos do mundo e exigem a atenção responsável e operante das comunidades nacionais e internacionais -, encontram-se também sujeitos a soluções falsas e ilusórias, em contraste com a verdade e o bem das pessoas e das nações (JOAO PAULO II, 2005, p. 11, grifos nossos).

24. É no íntimo da consciência moral que se consuma o eclipse do sentido de Deus e do homem, com todas as suas múltiplas e funestas consequências sobre a vida. Em questão está, antes de mais, a consciência de cada pessoa, onde esta, na sua unicidade e irrepetibilidade, se 
encontra a sós com Deus. Mas, em certo sentido, é posta em questão também a « consciência moral » da sociedade: esta é, de algum modo, responsável, não só porque tolera ou favorece comportamentos contrários à vida, mas também porque alimenta a «cultura da morte », chegando a criar e consolidar verdadeiras e próprias « estruturas de pecado » contra a vida. A consciência moral, tanto do indivíduo como da sociedade, está hoje - devido também à influência invasora de muitos meios de comunicação social —, exposta a um perigo gravíssimo e mortal: o perigo da confusão entre o bem e o mal, precisamente no que se refere ao fundamental direito à vida (JOAO PAULO II, 2005, p. 49, grifos nossos).

g) Livre preferência de Deus pelos mais fracos e indefesos: figurativizado pela proteção da vida humana anterior ao nascimento e dos doentes em fase terminal.

Também no momento da doença, o homem é chamado a viver a mesma entrega ao Senhor e a renovar a sua confiança fundamental naquele que "cura todas as suas enfermidades" (JOÃO PAULO II, 2005, p. 91, grifos nossos).

h) Nova integração divina (redenção de Cristo): "sangue de Cristo"; "vitória sobre o pecado".

É, enfim, do sangue de Cristo que todos os homens recebem a força para se empenharem a favor da vida. Precisamente esse sangue é o motivo mais forte de esperança, melhor é $o$ fundamento da certeza absoluta de que, segundo o desígnio de Deus, a vitória será da vida. " Nunca mais haverá morte »- exclama a voz poderosa que sai do trono de Deus na Jerusalém celeste $(A p 21,4)$. E S. Paulo assegura-nos que a vitória atual sobre o pecado é sinal e antecipação da vitória definitiva sobre a morte, quando « se cumprirá o que está escrito: "A morte foi tragada pela vitória. Onde está, ó morte, a tua vitória? Onde está, ó morte, o teu aguilhão?" » (1 Cor 15, 54-55) (JOAO PAULO II, 2005, p. 53, grifos nossos).

Observamos no enunciado a oposição entre dois percursos figurativos conflitantes: a isotopia da "cultura da morte", com as figuras dos atos contra a pessoa, da "cultura próaborto" e da "difusão da eutanásia"; por oposição à isotopia da "cultura da vida", da defesa e proteção da vida humana. A própria liberdade é figurativizada de modo diverso de acordo com a dupla leitura isotópica: "liberdade do progresso das posições incondicionalmente a favor da vida" vs. "liberdade individualista que acaba por ser a liberdade dos mais fortes contra os débeis, destinados a sucumbir" (JOÃO PAULO II, 2005, p. 40).

Segundo Amorim (2004, p. 122-123): “a representação do outro a quem me dirijo já atua na própria divisão do discurso em partes". Ainda segundo a autora, "a presença do outro pode ser rastreada linguisticamente, isto é, através de formas gramaticais. Mas ela pode também não estar marcada no nível da frase e só ser identificável no interior do enunciado”. 
Nesse caso, segundo a autora, a presença do outro será identificável pelo "contraste de ideias no interior de um determinado texto", seja por um tom irônico, seja por um tom polêmico.

De acordo com Bakhtin/Volochinov (2004, p. 123):

Toda a palavra usada na fala real possui não apenas tema e significação no sentido objetivo, de conteúdo, desses termos, mas também um acento de valor ou apreciativo, isto é, quando um conteúdo objetivo é expresso (dito ou escrito) pela palavra viva, ele é sempre acompanhado por um acento apreciativo determinado. Sem acento apreciativo, não há palavra.

Vejamos como esse acento de valor apreciativo é transmitido por meio de uma entonação expressiva, segundo a qual a presença do outro é identificável por determinadas marcas linguísticas. Verificamos, portanto, como se constitui o contraste de ideias entre o ponto de vista defendido e o rechaçado pelo enunciado. Desse modo, podemos observar a presença da palavra alheia. Atentemos ao seguinte excerto:

11. Mas queremos concentrar a nossa atenção, de modo particular, sobre outro gênero de atentados, relativos à vida nascente e terminal, que apresentam novas características em relação ao passado e levantam problemas de singular gravidade: é que, na consciência coletiva, aqueles tendem a perder o caráter de « crimes » para assumir, paradoxalmente, o caráter de « direitos », a ponto de se pretender um verdadeiro e próprio reconhecimento legal da parte do Estado e a consequente execução gratuita por intermédio dos profissionais da saúde. Tais atentados ferem a vida humana em situações de máxima fragilidade, quando se acha privada de qualquer capacidade de defesa. Mais grave ainda é o fato de serem consumados, em grande parte, mesmo no seio e por obra da família que está, pelo contrário, chamada constitutivamente a ser « santuário da vida » (JOAO PAULO II, 2005, p. 25-26).

Por meio desse enunciado já se assume a posição valorativa da esfera ideológica católica na qual a encíclica se insere. O conteúdo temático é assumido pela voz do comentador (agente de prestígio; Papa), de tal forma que o texto vai sendo amarrado argumentativamente pela posição valorativa da esfera religiosa. A própria expressão "gênero de atentados, relativos à vida nascente e terminal" assinala essa posição valorativa.

Verifica-se a presença do tom polêmico na própria referência ao outro, "Estado e profissionais da saúde", ao agirem como instituições pró-aborto, com largo apoio da mídia e das esferas legais. Discursiviza-se a atitude responsiva entre os dois discursos (biomédico e Estatal), segundo o qual o enunciado estabelece uma relação de afirmação-objeção. $\mathrm{O}$ enunciado desenvolve-se, fazendo prevalecer o efeito de sentido de monofonia, isto é, 
mediante o abafamento das vozes e dos percursos em conflito em relação às formações ideológicas conflitantes.

Podemos, então, definir o estilo do gênero que projeta o ator da enunciação da encíclica como um éthos. A encíclica, ao apresentar um estilo caracterizado por um conteúdo doutrinário (matéria de fé e moral), precisão, referências à língua latina e pelo efeito de inquestionabilidade consumado pela utilização da narrativa bíblica fundadora, projeta um éthos de tom de voz altivo e apegado aos valores da tradição. Esse é o éthos projetado pela encíclica que, ao operar com a reduplicação mítica do discurso fundante, vai fazer a divulgação religiosa por meio da concretude das figuras, firmando o mito pelo mito. Temos a projeção de um éthos altivo, superior, autoritário e detentor de uma verdade inquestionável, pois respaldado nas verdades enunciadas no discurso fundante das Sagradas Escrituras.

Dessa forma, podemos concluir que, contrariamente ao discurso fundador, pautado por um sujeito determinado segundo a concentração, há, no discurso de divulgação religiosa, um sujeito determinado segundo a expansão. Essa expansão se verifica pela explicitação do enredamento do preenchimento de lacunas semânticas, com o estabelecimento de fronteiras traçadas para o fiel. O fiel tem de ser orientado e ensinado: é necessário que se privilegie o contínuo, para que a previsibilidade o sustente com segurança. Por meio dessa previsibilidade é que se espera encontrar a imagem do sujeito produzida nos textos que materializam a divulgação religiosa.

Os valores católicos de defesa da vida, veiculados por esse objeto-discurso, são propostos pela enunciação divulgadora, no papel actancial de um destinador-manipulador, cujos ideais, postos como objeto de valor a serem partilhados com o enunciatário, são compatíveis à formação discursiva católica. Esse mesmo sujeito da enunciação, no papel também de agente de prestígio, dentro do campo discursivo católico, tem seu fazer reconhecido: a exposição da matéria de fé e moral deve ser executada e praticada pelos membros participantes e cúmplices da formação discursiva considerada. A formação discursiva, como sistema fundado em figuras e temas de determinado discurso, acaba por esclarecer o lugar do sujeito na polêmica sobre a preservação da vida. 


\subsubsection{O éthos da divulgação religiosa especializada}

Se a nossa proposta consiste em fornecer as bases para a operacionalização da noção de éthos, no que diz respeito à associação entre semiótica tensiva e retórica, no que concerne à noção de estilo, vejamos os procedimentos argumentativos utilizados pelo enunciador da divulgação especializada, segundo os quais é possível entrever seu corpo, tom, voz, caráter e corporalidade na constituição de um modo de dizer e de ser específicos.

a) Argumento de autoridade

O primeiro recurso argumentativo empregado é o argumento de autoridade. Há uma retórica característica de todos os discursos institucionais: a autoridade concedida à tomada da palavra pelo porta-voz autorizado coincide com os limites delegados pela instituição. As características da linguagem dos quadros dos porta-vozes delegados de quaisquer instituições derivam da posição que ocupam esses depositários da autoridade delegada.

O uso da linguagem, ou melhor, tanto a maneira como a matéria do discurso, depende da posição social do locutor que, por sua vez, comanda o acesso que se lhe abre à língua da instituição, à palavra oficial, ortodoxa, legítima (BOURDIEU, 1998, p. 87).

De acordo com Bourdieu (1998), para que um enunciado seja reconhecido ele deve ser pronunciado por alguém autorizado a fazê-lo. O enunciador (voz autorizada: máxima autoridade da Igreja Católica) e os enunciatários aos quais ele se dirige são designados no próprio título da referida carta. Essa destinação aparece na forma de uma saudação inicial:

Carta Encíclica

Evangelium Vitae

Do sumo Pontífice

João Paulo II

Aos Bispos

Aos Presbíteros e Diáconos

Aos religiosos e religiosas

Aos fiéis leigos

$\mathrm{E}$ a todas as pessoas de Boa Vontade

Sobre o valor e a inviolabilidade da vida humana

(JOÃO PAULO II, 2007, p.3) 
Citações e alusões bíblicas permeiam o enunciado da encíclica e da constituição pastoral, a fim de lhes conferir o caráter de instrumento autorizado. Vejamos alguns excertos:

"Deus é amor, e quem permanece no amor permanece em Deus e Deus nele" ( $1 \mathrm{Jo} 4,16)$ (BENTO XVI, 2008, p.3).

O crente israelita, de facto, reza todos os dias com as palavras do Livro do Deuteronómio, nas quais sabe que está contido o centro da sua existência: "Escuta, ó Israel! O Senhor, nosso Deus, é o único Senhor! Amarás ao Senhor, teu Deus, com todo o teu coração, com toda a tua alma e com todas as tuas forças" $(6,4-5)$. Jesus uniu - fazendo deles um único preceito - o mandamento do amor a Deus com o do amor ao próximo, contido no Livro do Levítico: "Amarás o teu próximo como a ti mesmo" (19, 18; cf. Mc 12,29-31). Dado que Deus foi o primeiro a amar-nos (cf. $1 \mathrm{Jo} 4,10$ ), agora o amor já não é apenas um "mandamento", mas é a resposta ao dom do amor com que Deus vem ao nosso encontro (BENTO XVI, 2008, p. 3-4)

A referência bíblica à Primeira Carta de João, "Deus é amor e quem permanece no amor, permanece em Deus e Deus nele” ( I Jo, 4, 16), colocada logo no início do enunciado da encíclica "Deus Caritas Est", constitui-se como fonte primeira e fiadora do discurso de divulgação especializada considerado, ou seja, instaura-se como discurso fundador do enunciado da encíclica, graças ao caráter de autoridade proporcionado pela palavra revelada. Essa referência bíblica é apresentada como a expressão do "centro da fé cristã: a imagem cristã de Deus e também a consequente imagem do homem e do seu caminho" (BENTO XVI, 2008, p. 3). Em seguida, no mesmo parágrafo, o autor expõe o que considera a fórmula sintética da existência cristã, presente no mesmo versículo bíblico: "Nós conhecemos e cremos no amor que Deus nos tem" (BENTO XVI, 2008, p. 3).

Por meio de um contrato fiduciário peculiar, o destinador busca convencer o destinatário-sujeito mediante a utilização do argumento de autoridade expresso pela referência à palavra divina. Verificamos a projeção do éthos de um intelectual cristão, que modula sua voz por meio de um tom instrucional. A referência à Sagrada Escritura institui-se como verdade inquestionável.

b) Argumentação pelo exemplo

Se tomarmos como base os procedimentos argumentativos, concernentes às ligações que fundam a estrutura do "real", estabelecidos por Perelman e Olbrechts-Tyteca (2005, p. 
413), no que diz respeito ao fundamento pelo caso particular, a estratégia argumentativa empregada para convencer e obter, consequentemente, a adesão do enunciatário, é a argumentação pelo exemplo. Herdamos a retórica, semiotizando a noção de "real" proposta por essa teoria.

\begin{abstract}
A Beata Teresa de Calcutá é um exemplo evidentíssimo do fato que o tempo dedicado a Deus na oração não só não lesa a eficácia nem a operosidade do amor ao próximo, mas é realmente a sua fonte inexaurível. Na sua carta para a Quaresma de 1996, esta Beata escrevia aos seus colaboradores leigos: "Nós precisamos desta união íntima com Deus na nossa vida quotidiana. E como poderemos obtê-la? Através da oração" (BENTO XVI, 2008, p. 67$68)$.
\end{abstract}

Madre Teresa de Calcutá, um caso particular, é estabelecido como um exemplo, um modelo de conduta a ser imitada. Outros exemplos da prática da caridade (caritas-ágape) mencionados no enunciado são os Santos:

40. Por fim, olhemos os Santos, aqueles que praticaram de forma exemplar a caridade. Penso, de modo especial, em Martinho de Tours (†397), primeiro soldado, depois monge e Bispo: como se fosse um ícone, ele mostra o valor insubstituível do testemunho individual da caridade. [...] Mas, na história da Igreja, quantos outros testemunhos de caridade podem ser citados! [...] Figuras de Santos como Francisco de Assis, Inácio de Loyola, João de Deus, Camilo de Léllis, Vicente de Paulo, Luísa de Marillac, José B. Cottolengo, João Bosco, Luís Orione, Teresa de Calcutá — para citar apenas alguns nomes - permanecem modelos insignes de caridade social para todos os homens de boa vontade. Os Santos são os verdadeiros portadores de luz dentro da história, porque são homens e mulheres de fé, esperança e caridade (BENTO XVI, 2008, p. 71-72).

Segundo Perelman e Olbrechts-Tyteca (2005, p. 414), para que alguém sirva de modelo "é porque possui [...] certo prestígio", dado que o modelo glorificado é posto a imitação de todos.

c) Perguntas retóricas

Outro recurso argumentativo empregado é a pergunta retórica. De acordo com Discini (2005, p. 340), o enunciador, por meio da utilização da pergunta retórica, "não necessita saber a resposta do leitor, pois a resposta é dada implicitamente no próprio texto". Desse modo, a 
pergunta retórica "define-se como meio para a construção da imagem positiva do leitor: aquele que é e sabe que é o legítimo participante da cena enunciativa" (Idem, ibidem).

Esse efeito de sentido cria um simulacro de subjetividade, com uma maior aproximação entre o leitor-aprendiz e o enunciador da encíclica instrucional. Vejamos:

6. Concretamente, como se deve configurar tal caminho de ascese e purificação? Como deve ser vivido o amor, para que se realize plenamente a sua promessa humana e divina? Uma primeira indicação importante, podemos encontrá-la no Cântico dos Cânticos, um dos livros do Antigo Testamento bem conhecido dos místicos (BENTO XVI, 2008, p, 13)

Observamos aí o estabelecimento do simulacro de uma interação conversacional por meio da instauração de perguntas e respostas, à moda de perguntas retóricas. Simula-se um jogo simultâneo de vozes (a do interlocutor e a do interlocutário).

Mediante a instauração dessa cena, obtém-se o efeito de sentido de anulação da distância entre enunciação e enunciado. Esse jogo de vozes constrói uma ilusão de realidade, a ilusão de uma situação real de diálogo. Simula-se a cena de doação de saber, do ensino da doutrina, pautada pela exposição do conteúdo realizada pelo enunciador e pela expectativa de assimilação a ser feita pelo enunciatário.

d) Semiótica e retórica: o argumento metalinguístico

Neste item, tomamos como base a associação com os conceitos advindos da semiótica tensiva e incorporados à retórica, no que diz respeito ao exame dos procedimentos argumentativos observados na carta encílica "Deus Caritas est".

Teríamos como resultante da argumentação dessa encíclica uma concepção una de amor, (compacta/concentração) que englobaria uma definição comum, ou teríamos uma concepção universalizante (difusa/expansão) que englobaria as demais?

Surge então a questão: todas estas formas de amor no fim de contas unificam-se sendo o amor, apesar de toda a diversidade das suas manifestações, em última instância um só, ou, ao contrário, utilizamos uma mesma palavra para indicar realidades totalmente diferentes? (BENTO XVI, 2008, p. 8)

No que diz respeito à concentração, no que concerne à intensidade perceptiva, estaríamos na presença do compacto, "a intensidade está no auge, e a morfologia associada é a 
do uno, do singular". Já “com o difuso, [...] a máxima difusão da cisão culmina, agora, na pluralização, que é a morfologia mais intensa" (FONTANILLE; ZILBERBERG, 2001, p. 137).

Caracterizaríamos a encíclica, dessa forma, mediante a utilização do estilo ascendente, segundo a orientação do menos para o mais, ou de um estilo descendente, dirigido do mais para o menos?

Como se coloca o confronto de ideias e, por conseguinte, de pontos de vista que constituem a referida carta encíclica, cujo fio condutor é "suscitar no mundo um renovado dinamismo de empenhamento na resposta humana ao amor divino" (BENTO XVI, 2008, p.5)? Por intermédio de quais recursos discursivos configura-se o posicionamento do sujeito, como aquele que é contrário às concepções mundanas de amor e que permeiam a sociedade contemporânea? De acordo com essas concepções mundanas, o “eros degradado a puro 'sexo' torna-se mercadoria, torna-se simplesmente uma 'coisa' que se pode comprar e vender; antes, o próprio homem torna-se mercadoria” (BENTO XVI, 2008, p. 12). Teria o cristianismo destruído verdadeiramente o eros? Essas são algumas das questões que procuramos elucidar por meio da análise proposta.

Para tanto, o enunciador inicia essa questão por meio do desenvolvimento da utilização do argumento metalinguístico. Ele procede à exposição do campo semântico da palavra amor. Desenvolve-se no enunciado uma questão etimológica a respeito dos usos e interpretações da palavra amor. O enunciador utiliza-se da definição oratória, que, conforme Perelman e Olbrechts-Tyteca (2005, p.195), "é uma figura de escolha, pois utiliza a estrutura da definição, não para fornecer o sentido de uma palavra, mas para por em destaque certos aspectos de uma realidade que correriam o risco de ficar no último plano da consciência”.

As definições de eros (amor carnal), agape (termo característico para a concepção bíblica de amor) e philia (amor de amizade) vão sendo expandidas ao longo do enunciado da encíclica.

A expansão, modo de funcionamento metalinguístico do discurso, é utilizada mediante uma formulação sintaticamente delimitada: a definição.

Inicialmente, o autor da encíclica procede à definição da concepção de eros: "ao amor entre homem e mulher, que não nasce da inteligência e da vontade, mas de certa forma impõese ao humano, a Grécia antiga deu o nome de eros" (BENTO XVI, 2008, p. 8). 
Por meio da instituição de uma pergunta retórica, "O cristianismo destruiu, verdadeiramente, o eros?", o enunciador põe em seu discurso uma possível réplica do enunciatário, segundo a qual se segue a argumentação contra seu outro, no caso, o filósofo alemão Friedrich Nietzsche que, consoante esse enunciado, teria agido de modo falacioso. "Segundo Friedrich Nietzsche, o cristianismo teria dado veneno a beber ao eros, que, embora não tivesse morrido, daí teria recebido o impulso para degenerar em vício” (Idem, p. 9).

São apresentadas, em seguida, as concepções de eros, que contrariam os princípios cristãos e com as quais o enunciador se defronta. No discurso papal, o dialogimo está silenciado, visto que as vozes em confronto estão sob o controle dele, máxima autoridade da Igreja.

O enunciador retoma a questão suscitada logo de início. A mensagem sobre o amor anunciada pela Bíblia e a tradição da Igreja se oporiam a essa experiência comum do amor? É justamente essa questão que o enunciador procura responder. Para responder a ela, o autor apresenta como fundamentais as definições de eros "como termo para significar o amor "mundano" e de ágape "como expressão do amor fundado sobre a fé e por ela plasmado", além de retomar a contraposição que se estabelece frequentemente entre as duas concepções, “como amor 'ascendente' e amor 'descendente"” (Idem, p. 15-16):

Se se quisesse levar ao extremo esta antítese, a essência do cristianismo terminaria
desarticulada das relações básicas e vitais da existência humana e constituiria um mundo
independente, considerado talvez admirável, mas decididamente separado do conjunto da
existência humana. Na realidade, eros e agape - amor ascendente e amor descendente -
nunca se deixam separar completamente um do outro. Quanto mais os dois encontrarem a
justa unidade, embora em distintas dimensões, na única realidade do amor, tanto mais se
realiza a verdadeira natureza do amor em geral.

Diante dessa questão, o enunciador argumenta em favor de uma única realidade, ainda que em distintas dimensões.

8. Encontramos, assim, uma primeira resposta, ainda bastante genérica, para as duas questões atrás expostas: no fundo, o 'amor' é uma única realidade, embora com distintas dimensões; caso a caso, pode uma ou outra dimensão sobressair mais (BENTO XVI, 2008, p. 18).

Segue-se a universalização do conceito de amor, segundo a qual o amor a Deus e ao próximo se unificam: “Amor a Deus e amor ao próximo fundem-se num todo: no mais pequenino, encontramos o próprio Jesus e, em Jesus, encontramos Deus" (BENTO XVI, 2008, p. 29. 
Por fim, na segunda parte da referida encíclica, ao se referir à prática de amor na Igreja, o enunciador institui a dimensão caritas-agape como universalidade do mandamento do amor.

\begin{abstract}
A Igreja é a família de Deus no mundo. Nesta família, não deve haver ninguém que sofra por falta do necessário. Ao mesmo tempo, porém, a caritas-agape estende-se para além das fronteiras da Igreja; a parábola do bom Samaritano permanece como critério de medida, impondo a universalidade do amor que se inclina para o necessitado encontrado «por acaso » (cf. $L c 10,31$ ), seja ele quem for (BENTO XVI, 2008, p. 42-43).
\end{abstract}

Tomamos por base a noção de isotopia, determinada pelo ponto de vista do enunciador, que orienta o crivo de leitura, tornando homogênea a superfície do texto. Consideramos a configuração discursiva, conforme propõe Barros (2002, p. 120), “como uma espécie de 'lexema do discurso', que subsume vários percursos figurativos e temáticos, além dos narrativos, e conta com algumas figuras invariantes". Respaldados pelo conceito de polissememia (GREIMAS; COURTÉS, 2008, p. 376) que "corresponde à presença de mais de um semema no interior de um lexema", identificamos três sememas diferentes dentro de uma narrativa supostamente homogênea. Esses sememas compõem o lexema polissememêmico “amor". Podemos distinguir, portanto, os seguintes sememas na determinação da leitura de um enunciado específico: a) eros (temática do amor mundano); b) ágape (amor cristão); c) philia (temática do amor fraterno). A esses se sobrepõe a temática do amor caridade (caritasagape), que engloba todas as dimensões anteriores.

A definição de caritas-agape não pode ser condensada em uma concepção particularizante de amor, dado que ela engloba as demais. Assim se estabelece o lexema polissememêmico "amor", segundo o qual identificamos diferentes sememas que o compõem.

Segue-se a argumentação mediante a exposição da situação geral do empenho pela justiça e amor no mundo contemporâneo (contemporaneidade do enunciado). Dessa forma, o enunciador visa aproximar-se de seu enunciatário para que ele atenda, por meio da realização de sua performance, ao convite deixado por intermédio desta carta encíclica, "Viver o amor e, deste modo, fazer entrar a luz de Deus no mundo".

Podemos verificar, mediante a análise realizada, que o estilo da encíclica não é caracterizado por uma concepção particularizante, una e concentrada de amor, mas por uma concepção difusa e ampla. 
Desse modo, temos como característica desse enunciado, a direcionalidade tensiva orientada para a retenção. Das noções de eros, apresentadas e contrapostas, logo no início da presente encíclica, a que se seguiram as definições de ágape e philia, desenvolve-se, por conseguinte, a noção de caritas-agape, que se constitui como uma concepção universalizante de amor. Nesse sentido, ao levarmos em conta a apreensão perceptiva desse texto (FONTANILLE; ZILBERBERG, 2001, p. 130), podemos concluir que na primeira parte da encíclica, na qual são apresentadas e contrapostas as definições de eros, agape e philia, temos a dominância de valores de absoluto na caracterização das distintas acepções de amor (eros, ágape e philia), associando-as à triagem axiológica. Aí domina o foco perceptivo sobre a apreensão. Segue-se, no enunciado, mediante a definição universalizante do amor como caritas-agape, o tipo perceptivo da apreensão, ligado a valores de universo, e que relacionamos, por sua vez, às operações de mistura e totalização axiológicas.

\subsubsection{Breves considerações sobre o éthos da divulgação religiosa especializada}

Com base nesses pressupostos, os resultados de nossa análise incidem na caracterização dos enunciados como pertencentes a uma divulgação definida segundo os parâmetros da "ciência da religião", o que projeta o papel específico do éthos do enunciador, orientado por meio de um tom de voz próprio à cena enunciativa pressuposta. A formação discursiva, como sistema de crenças e aspirações, fundado em figuras e temas de determinado discurso, e a escolha de recursos relativos à gramática da língua refletem na incorporação do éthos de um "intelectual cristão", apresentado mediante uma entonação discursiva peculiar a cada uma das partes constituintes dos textos recortados. Observamos, assim, o éthos de um intelectual católico, de um teólogo que pretende defender, construindo e não apenas transmitindo, as bases de uma doutrina universal. 


\subsection{Divulgação religiosa instrucional}

Bem cedo passou-se a chamar catequese o conjunto de esforços empreendidos na Igreja para fazer discípulos, para ajudar os homens a crerem que Jesus é o filho de Deus, a fim de que, por meio da fé, tenham a vida em nome dele, para educá-los e instruí-los nesta vida, e assim construir o Corpo de Cristo. A catequese é uma educação da fé das crianças, dos jovens e dos adultos, a qual compreende especialmente um ensino da doutrina cristã, dado em geral de maneira orgânica e sistemática, com os fim de os iniciar na plenitude da vida cristã.

Papa João Paulo II $^{61}$

\subsubsection{Análise de um gênero de divulgação religiosa instrucional: Compêndio do Catecismo da Igreja Católica}

Tomemos um gênero de divulgação religiosa, o catecismo para adultos da Igreja Católica, designado Compêndio. O Compêndio do Catecismo da Igreja Católica confirma o gênero catecismo, ao se oferecer como um manual que realiza a exposição completa e integral da doutrina católica acerca da fé e dos costumes. As fontes principais de que o gênero catequético se utiliza são: a palavra da Sagrada Escritura, dos Santos Padres, da Liturgia e do Magistério da Igreja.

O catecismo configura-se como um instrumento autorizado para a realização da catequese, tanto de jovens, quanto de adultos. Desse modo, seu público-alvo é formado por: "cada pessoa que, vivendo num mundo dispersivo e de mensagens múltiplas, deseja conhecer o Caminho da Vida, a Verdade confiada por Deus à Igreja do seu Filho" (BENTO XVI, 2005, p. 10).

O Compêndio se apresenta como uma versão sintética do conteúdo do Catecismo da Igreja Católica: Edição Típica Vaticana (JOÃO PAULO II, 2000). O Compêndio, ao se caracterizar como síntese da versão típica, tem por função disseminar os elementos da fé católica e, dessa forma, constitui-se como um mecanismo de divulgação para que o Catecismo da Igreja Católica: Edição Típica Vaticana seja mais conhecido e aprofundado.

O Compêndio divulgador traz como temática a exposição, de forma concisa, de todos os elementos essenciais em matéria de fé e moral da Igreja Católica. Não esqueçamos que

\footnotetext{
${ }^{61}$ João Paulo II (2000, p. 14).
} 
esses "elementos essenciais" serão considerados efeito de sentido e serão analisados como um modo próprio de argumentar de uma enunciação que quer fazer-crer e fazer-fazer, ou seja, converter.

Assim como o Catecismo de Roma, o Compêndio também se estrutura em quatro partes, "em correspondência com as leis fundamentais da vida em Cristo" (BENTO XVI, 2005, p. 14). Essa articulação do conteúdo em quatro partes retoma a antiga ordem tradicional seguida pelo gênero catequético que fora introduzida pelo Catecismo de São Pio V. Cada parte corresponde a cada um dos quatro dos pilares da fé católica: o Credo, os Sacramentos, os Mandamentos e o Pai-nosso.

Estas são as quatro partes referidas: a) "A profissão de fé"; b) "A celebração do mistério cristão", c) “A vida em Cristo"; d) "A oração cristã".

O destinador-manipulador (Papa, catequista) institui um contrato fiduciário com o destinatário-sujeito (fiel), por meio do estabelecimento do mistério cristão como objeto de fé. $\mathrm{O}$ destinador-manipulador $\left(\mathrm{S}_{2}\right.$, Papa), revestido da autoridade que lhe foi outorgada discursivamente, estabelece, por meio da modalidade factitiva (fazer-fazer), um fazer persuasivo através do qual manipula os agentes religiosos divulgadores ( $\mathrm{S}_{3}$, catequistas) a transmitirem o objeto modal (saber a respeito da doutrina católica) aos catecúmenos $\left(\mathrm{S}_{4}\right.$, fiéis).O destinatário-sujeito (fiel), por intermédio de seu fazer interpretativo, ao crer como verdadeiro esse objeto de fé, deve professar a fé em um só Deus: o Pai todo-poderoso, o Criador; Jesus Cristo, seu Filho, nosso Senhor e Salvador; e o Espírito Santo, na Santa Igreja Católica (primeira parte).

Façamos uma síntese dessas relações narrativas:

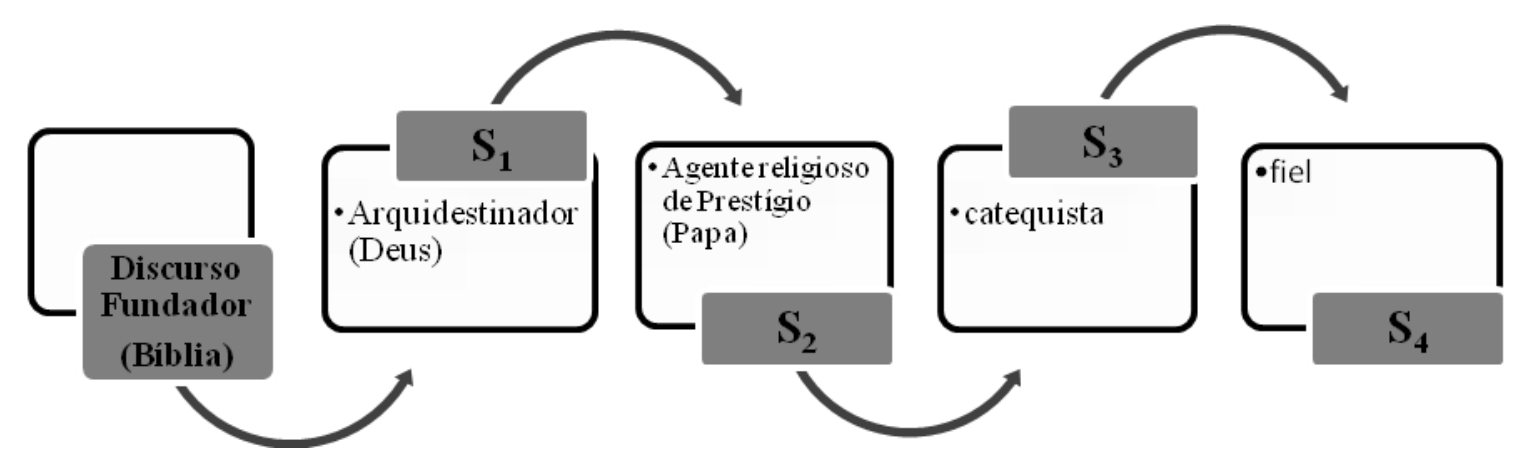

Figura 16. Discurso de divulgação religiosa instrucional: catecismo. 
O destinatário-sujeito (fiel), após ter estabelecido o julgamento epistêmico e professado a crença no mistério cristão, recebe o $\mathrm{O}_{\mathrm{v}}$ "graça divina", fruto das ações sacramentais, por meio do PN de atribuição de competência realizado pelo destinadormanipulador (segunda parte).

Por conseguinte, o destinatário-sujeito (fiel), ao ter adquirido o $\mathrm{O}_{\mathrm{v}}$ "graça divina", obtém o dom necessário para a realização da performance do "agir cristão" mediante a prática dos mandamentos (terceira parte). Tal agir é caracterizado como "um agir reto e livre, com a ajuda da fé da graça de Deus" (JOÃO PAULO II, 2000, p. 17).

Na última parte, "A oração cristã", o destinatário-sujeito (fiel) recebe o $\mathrm{O}_{\mathrm{m}}$ "poder", que faz com que ele utilize a figura exemplar de Jesus, mantenha-se em conjunção com o $\mathrm{O}_{\mathrm{v}}$ "graça divina" e possa alcançar a salvação eterna.

Por fim, o Compêndio divulgador apresenta em apêndice os seguintes itens: a) Orações comuns (Sinal da Cruz, Glória ao Pai, Ave Maria, Salve-Rainha, etc.); b) Fórmulas de doutrina católica (Os mandamentos de caridade, A regra de ouro (Mt 7, 12), As Bemaventuranças (Mt 5, 3-12), As virtudes teologais, As virtudes cardeais, Os dons do Espírito Santo, Os frutos do Espírito Santo, Os mandamentos da Igreja, As obras de misericórdia corporal, As obras de misericórdia espiritual, Os vícios capitais e Os novíssimos).

\subsubsection{Análise de uma unidade "Capítulo Terceiro: A vida de oração" (T9)}

O gênero compêndio, ao trazer a doutrina católica com a exposição da prática da oração apresentada em seu enunciado, prescreve uma série de comportamentos regrados e recorrentes, que devem ser realizados pelo sujeito para que ele possa manter-se em conjunção com o objeto-valor "graça divina".

Ao se constituir por meio da modalidade do dever-ser e dever-agir de acordo com o modo de vida, cuja receita é dada no próprio enunciado, o catecismo apresenta uma percepção orientada pelo polo do sagrado. Assim, podemos considerar o enunciado catequético como um texto instrucional programador, na medida em que possibilita ao destinatário a aquisição de uma competência: "saber ser católico".

Vejamos os seguintes excertos: 


\section{7. ${ }^{62}$ Quais momentos são mais indicados para a oração?}

Todos os momentos são indicados para a oração, mas a Igreja propõe aos fiéis ritmos destinados a alimentar a oração contínua: orações da manhã e da noite, antes e depois das refeições; liturgia das Horas; Eucaristia dominical; santo Rosário; festas do ano litúrgico. $2697-26982720^{63}$

"É preciso lembrar-se de Deus com mais frequência do que se respira" (São Gregório Nazianzeno).

\section{O Combate da Oração}

\section{Por que a oração é um combate?}

A oração é um dom da graça, mas pressupõe sempre uma resposta decidida de nossa parte, porque aquele que reza combate contra si mesmo, o ambiente e sobretudo contra o Tentador, que faz de tudo para o distrair da oração. O combate da oração é inseparável do progresso da vida espiritual. Reza-se como se vive, porque se vive como se reza. 2725(BENTO XVI, 2005, p. 170-171, grifos nossos).

As lições presentes nos artigos estruturam-se por meio de uma heterogeneidade mostrada e marcada: temos perguntas de um narrador e respostas de um narratário em uma simulação de discurso direto. A noção de heterogeneidade foi estabelecida por Authier-Revuz (1982), com base nos princípios bakhtinianos. A heterogeneidade corresponde às distintas configurações pelas quais o discurso é atravessado por diferentes vozes. Essa noção está exposta, na lição, de uma forma mostrada e marcada que corresponde à presença do outro na cadeia do discurso, explicitamente demarcado por meio de marcas linguísticas.

A estrutura composicional do texto retoma a forma do antigo gênero literário catequético estruturado em perguntas e respostas. A utilização da heterogeneidade mostrada e

\footnotetext{
${ }^{62}$ Essa numeração inicial, tal como observamos no enunciado das encíclicas, constitui a referência dos parágrafos apresentada pelo enunciado do compêndio.

${ }^{63}$ A estreita dependência do compêndio em relação ao Catecismo de Roma manifesta-se por um espelhamento discursivo. Tomamos o conceito de espelhamento discursivo como um tipo particular de interdiscursividade que pode ser expandida além do conceito de alusão. Além da incorporação interdiscursiva de temas e figuras do texto fonte (Catecismo de Roma), verifica-se também a presença de um jogo especular em que o texto fonte, tido como modelo, reflete-se no Compêndio divulgador em um completo entrelaçamento diagramático e discursivo. Observamos a presença de um entrelaçamento diagramático entre as questões propostas pelo Compêndio divulgador e os parágrafos a que elas se referem no Catecismo de Roma. A indicação dos números de referência (2697-2698 2720) dispostos logo abaixo de cada questão do Compêndio, alude ao parágrafo no qual tal questão se encontra desenvolvida no Catecismo.
} 
marcada apresenta três finalidades essenciais: a) produzir um simulacro dialógico de um encontro catequético entre mestre e discípulo; b) reduzir o conteúdo ao essencial; c) favorecer a assimilação e memorização dos conteúdos expostos.

$\mathrm{O}$ sujeito $\left(\mathrm{S}_{3}\right)$, já conjunto com o $\mathrm{O}_{\mathrm{v}}$ "dom da graça divina", recebe o $\mathrm{O}_{\mathrm{m}}$ "poder ter o poder e força para resistir aos assaltos da tentação". As temáticas do combate, da defesa da vida divina e da Santa Igreja se verificam nesse enunciado e figurativizam-se no "Combate da Oração".

Constrói-se a imagem de um sujeito que, ao agir conforme as prescrições estabelecidas, permanecerá conjunto com tais valores.

Ao tomarmos como base a proposição de que as escolhas dos valores tensivos, realizados pela instância pressuposta do sujeito da enunciação desde as etapas mais profundas do modelo, pressupõem também a escolha de modulações de velocidade, transportamo-nos ao domínio do andamento.

Desse modo, o compromisso do enunciador catequético com os valores extensos, emissivos e com o andamento desacelerado ${ }^{64}$ reflete o receio da velocidade e da interrupção brusca que, ao serem ocasionados pelo anti-PN (o Tentador), certamente acarretariam uma fratura no próprio ser e nos laços que o tornariam unido ao sistema religioso considerado.

Tendo efetuado essa análise, podemos definir o estilo, o éthos, do ator da enunciação do compêndio. O compêndio, caracterizado pela presença de um estilo marcado pela clareza, tem como objetivo encadear injunções, direta ou indiretamente. Podemos verificar, assim, a projeção de um éthos professoral, obtido mediante um efeito de didatismo peculiar, um éthos marcado por um tom de voz altivo e apegado aos valores da tradição.

\footnotetext{
${ }^{64}$ Entretanto, o ritual não necessita absolutamente da desaceleração, é possível que tenhamos rituais em domínios discursivos diferenciados em que a lentidão não seja predominante.
} 


\subsection{Divulgação para conscientização social}

\subsubsection{Campanha da fraternidade (CF 2008): o sujeito divulgador na ação evangelizadora}

No Brasil, a dimensão comunitária da Quaresma é vivenciada e assumida pela CF. A cada ano, a Igreja destaca uma situação da realidade social que precisa ser mudada. A CF ilumina, de modo particular, os gestos fundamentais desse tempo litúrgico: a oração, o jejum e a esmola.

Conferência Nacional dos Bispos do Brasil ${ }^{65}$

A Campanha da Fraternidade, coordenada pela Conferência Nacional dos Bispos do Brasil (CNBB), é uma atividade de evangelização desenvolvida durante o período da Quaresma, considerado, para essa formação ideológica, um tempo de conversão, mudança e preparação para a Páscoa. Essa campanha tem como critérios para escolha de temas: aspectos da vida da Igreja e da sociedade brasileira contemporânea.

O texto-base da CF de 2008 (T10) tem como tema: "Fraternidade e Defesa da Vida" e como lema: "Escolhe, pois, a vida (Dt 30,19)". A referência (Dt 30, 19) corresponde ao enunciado bíblico fundador do texto-base da campanha da fraternidade: livro de Deuteronômio, capítulo 30, versículo 19.

O conteúdo temático do texto referido se volta, predominantemente, à questão da defesa da vida humana e à polêmica motivada pelas práticas contemporâneas de disseminação do aborto, da eutanásia e das pesquisas envolvendo células-tronco embrionárias.

O enunciado se desenvolve mediante a oposição entre: a) temática relativista (ética relativista), figurativizada pelas diferentes formas de violência e atentados contra a vida, em especial contra a pessoa humana: "a luta contra o aborto, ou contra a manipulação de embriões humanos" (CF, p. 67); b) temática do valor inviolável da vida humana (visão integral da vida e da pessoa humana).

O enunciado apresenta uma composição diagramática estruturada em três partes, intercaladas e distribuídas em seções e parágrafos numerados: I. Ver - entre a cultura da vida e a cultura da morte; II. Julgar - Deus indica o caminho da vida; III. Agir - em defesa da vida.

\footnotetext{
${ }^{65}$ Conferência Nacional dos Bispos do Brasil - CNBB (2008, p. 131).
} 
O discurso fundador do texto-base da CNBB é apresentado como lema da Campanha da Fraternidade de 2008: Escolhe, pois, a vida (Dt 30, 19).

(Dt 30, 15 -19).

15. Eis que hoje estou colocando diante de ti a vida e a felicidade, a morte e a infelicidade [...].

19. Hoje tomo o céu e a terra como testemunhas contra vós: eu te propus a vida ou a morte, a benção ou a maldição. Escolhe, pois a vida, para que vivas tu e a tua descendência (BÍBLIA DE JERUSALÉM, 2004, p. 296).

A autoridade das Sagradas Escrituras, constantemente invocada pelos discursos de divulgação religiosa, também é utilizada como argumento de autoridade pelo texto-base da CNBB. Verificamos a presença de uma triagem de citações (Cf, MAINGUENEUAU, 2008), ou seja, a escolha, por parte do enunciador de textos citáveis por um determinado posicionamento na defesa de um ponto de vista.

O posicionamento corresponde à posição que um locutor ocupa em um campo de discussão, aos valores que ele defende (consciente ou inconscientemente) e que caracterizam reciprocamente sua identidade social e ideológica. Esses valores podem ser organizados em sistemas de pensamento (doutrinas) ou podem ser simplesmente organizados em normas de comportamento social que são então mais ou menos conscientemente adotadas pelos sujeitos sociais e que os caracterizam identitariamente (CHARAUDEAU; MAINGUENEAU, 2004, p. 393).

Vejamos a presença da citação bíblica no seguinte excerto, extraído do enunciado da $\mathrm{CF}$ :

154. Nesse discernimento, o chamado julgar significa exercer a recomendação de São Paulo, de "examinar tudo e guardar o que for bom" (1 Ts 5, 21), o verdadeiro caminho da vida. O juízo cristão, mais que uma condenação, é um convite à verdadeira vida (cf. Rm 2, 1-13) (CF, 2008).

Também como mecanismo argumentativo empregado pelo agente de prestígio vinculado à $\mathrm{CNBB}$, observamos o emprego da citação da palavra autoritária (documento papal - Encíclica Evangelium Vitae) na defesa do ponto de vista da esfera ideológica católica.

15. Logo no início da encíclica Evangelium Vitae, João Paulo II associa "a grandeza e o valor precioso da vida humana" ao "valor incomparável de cada pessoa humana" (CF, 2008, p. 16). 
Procuraremos estabelecer, inicialmente, a oposição semântica fundamental, representativa da organização mínima do texto. Para tanto, tomemos como base os seguintes segmentos recortados do texto analisado:

\section{INTRODUÇÃO}

A CF tem refletido, desde que foi realizada pela primeira vez, em 1964, sobre a vida em todas as suas dimensões. O motivo para tal encontra-se no fato de que a Campanha da Fraternidade acontece durante o tempo da Quaresma, tempo de conversão e mudança de vida em vista da festa da Ressurreição. Para que a conversão aconteça, se fazem necessárias uma profunda revisão de vida e uma renovada adesão a Deus. [...] A CF 2008 continua essa reflexão. Com o tema Fraternidade e defesa da vida e o lema Escolhe, pois, a vida (Dt 30, 19) ela expressa a preocupação com a vida humana, ameaçada desde o início por causa do aborto até sua consumação em vista da eutanásia (CF, 2008, p.9).

[...] O objetivo geral da CF- 2008 é levar a Igreja e a sociedade a defender e a promover a vida humana, desde a sua concepção até a sua morte natural, compreendida como dom de Deus e co-responsabilidade de todos na busca de sua plenificação, a partir da beleza e do sentido da vida em todas as circunstâncias, e do compromisso ético do amor fraterno (CF, 2008, p. 14).

A oposição semântica fundamental é estabelecida nesse discurso entre os termos contrários "vida e morte". O sistema católico de valores é determinado da seguinte maneira: a defesa da vida é axiologizada com valores eufóricos e as ameaças à vida ("morte") são axiologizadas com valores disfóricos.

Esse modo específico de axiologizar valores corresponde aos preceitos de uma determinada formação ideológica, no caso, os valores propugnados pela ideologia religiosa católica e materializados no nível discursivo. A ideologia católica faz-se presente como feixe de valores prescritos por sua doutrina por meio da expectativa de adesão (conversão) do fiel aos conteúdos da fé, da moral e das práticas cristãs. Os valores não prescritos e, consequentemente, tidos como transgressores da crença e moral católicas e de tendência disforizante, constituem aqueles que, ao pararem de cumprir os seus deveres de católico, deixem-se levar por práticas que ameacem a integridade da vida.

Tomemos o seguinte excerto:

Esta Campanha quer ser mais um esforço quaresmal de todos os cristãos, no sentido de buscar uma fidelidade ainda maior ao Deus criador e doador da vida. Essa conversão é tanto necessária quanto oportuna. Necessária porque ainda estamos distantes do ideal de vida presente no projeto da criação. Oportuna, devido às grandes ameaças que a vida vem sofrendo nos dias atuais e que exigem de todos nós um corajoso protagonismo para defendê-la, seja no seu início, decurso ou término (CF, 2008, p. 7). 
No que concerne ao PN (programa narrativo de base) que rege esse discurso, observamos que o enunciador, no papel de agente de prestígio vinculado à CNBB, visa estabelecer um contrato fiduciário com o enunciatário (fiel), para que este adquira a competência esperada (conversão) e possa manter-se em conjunção com os valores de defesa da vida cristã.

Vejamos:

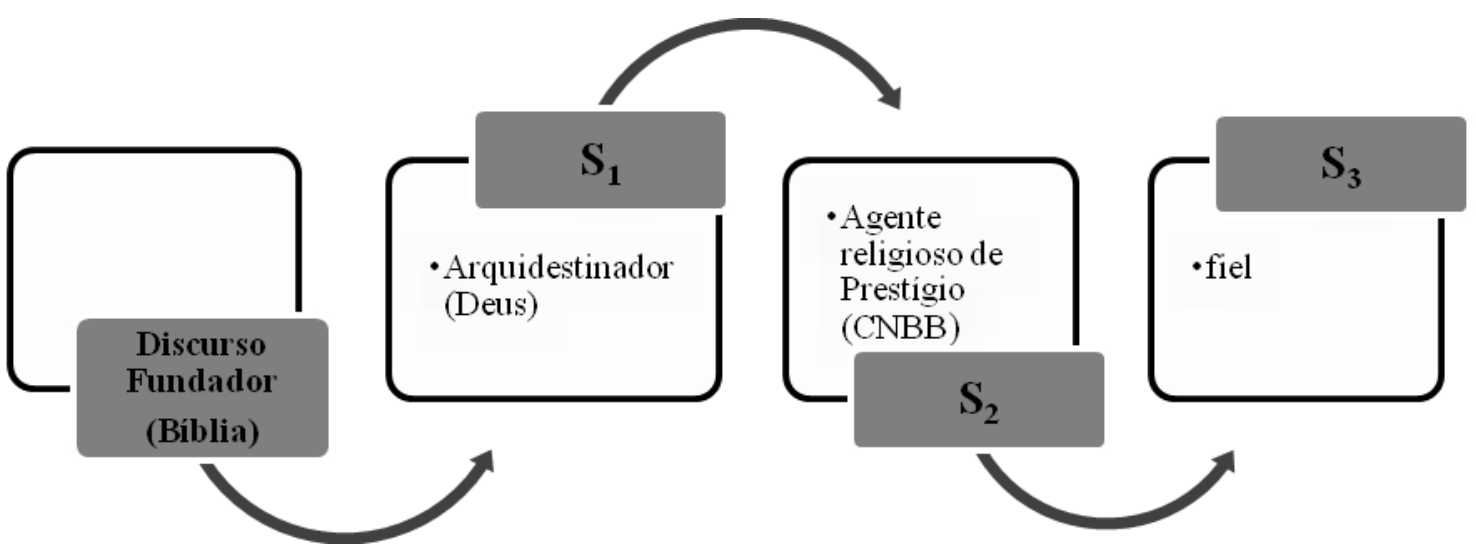

Figura 17. Divulgação para conscientização social.

Voltemos à estruturação do enunciado em três partes intercaladas. Tomemos o seguinte excerto:

Utilizando o método Ver-Julgar-Agir, [a CF 2008] busca olhar a realidade social e iluminá-la mostrando o Deus vivo que nos dá a vida e as decorrências éticas dessa verdade para então propor caminhos de conversão e de transformação da sociedade a fim de que a pessoa humana seja sempre valorizada em sua plenitude, conforme a sua natureza e vontade de Deus, de modo que a vida seja um dos principais fundamentos da hierarquia de valores que marca nosso existir e determina nosso agir (CF, 2008, p. 9).

Depreendamos desse excerto, o percurso do destinador manipulador, que se estende nesta outra passagem:

16 $6^{66}$. A CF-2008 nos propõe assumir uma atitude corajosa em favor da vida, a partir da constatação do valor incondicional e inviolável da vida humana. Para isso, precisamos iniciar

\footnotetext{
${ }^{66}$ Todas as indicações numéricas, que antecedem as citações, referem-se à estrutura composicional do enunciado da CF 2008, pautado pela divisão em parágrafos numerados.
} 
nossa reflexão partindo de uma visão geral da vida e da pessoa humana - a partir de sua realidade existencial - condizente com sua dignidade e que se contrapõe aos modelos reducionistas tão difundidos em nossa época (CF, 2008, p. 16).

O destinador-manipulador estabelece um contrato fiduciário, segundo o qual manipula o enunciatário a "assumir um atitude corajosa em favor da vida, a partir da constatação do valor incondicional e inviolável da pessoa humana" (CF, 2008, p. 16).

De acordo com Barros (2005, p. 28), "no percurso do destinador-manipulador, o programa de competência é examinado não na perspectiva do sujeito de estado que recebe os valores modais, mas do ponto de vista do sujeito doador ou destinador desses valores”. Desse modo, articulam-se, no enunciado, as duas etapas hierarquizadas desse processo: a competência semântica e a competência modal. A atribuição da competência semântica que, ainda conforme Barros (Idem, ibidem), está sempre pressuposta na competência modal, configura-se mediante o crer do sujeito, que deve crer como verdadeiro esse discurso. Para isso, o enunciado é pronunciado por alguém autorizado a fazê-lo: o sujeito da enunciação coloca-se no papel também de agente de prestígio vinculado à $\mathrm{CNBB}$, dentro do campo discursivo católico.

Na segunda etapa do percurso do destinador-manipulador (atribuição de competência modal), o destinador confere ao destinatário-sujeito, os valores modais do querer-fazer e do dever-fazer, querer e dever tomar "uma atitude corajosa em favor da vida a partir da constatação do valor incondicional e inviolável da vida humana” (CF, 2008, p.16).

O enunciador tem seu fazer reconhecido: a exposição da matéria de fé e moral deve ser executada e praticada pelos membros participantes e cúmplices da formação discursiva considerada. Passemos agora a examinar certa atitude de julgamento epistêmico, desdobrado em novos programas do sujeito da performance.

152. Diante da complexa realidade que nos é apresentada, percebemos que o grande desafio da humanidade é saber discernir entre os conhecimentos e as práticas que levam a uma plenitude da vida e os conhecimentos e práticas que desviam deste caminho, colocando-se a serviço da morte. Desenvolver a capacidade de discernir torna-se hoje, uma necessidade fundamental para o bem viver.

[...] 154. Nesse discernimento, o chamado julgar significa exercer a recomendação de São Paulo, de "examinar tudo e reter o que é bom" (1 Tes 5, 21), o verdadeiro caminho da vida. O juízo cristão, mais que uma condenação, é um convite a verdadeira vida (cf. Rm 2, 1-13) (CF, 2008, p. 66). 
"As modalidades epistêmicas dizem respeito à competência do enunciatário que, em seguida ao seu fazer interpretativo, toma a cargo, assume (ou sanciona) as posições cognitivas formuladas pelo enunciador (ou submetidas pelo sujeito)" (GREIMAS; COURTÉS, 2008, p. 172).

Realiza-se, por conseguinte, a performance da decisão, situada na dimensão cognitiva. O destinador manipulador (agente da CNBB) estimula o enunciatário (fiel católico) a discernir entre "os conhecimentos e as práticas que levam a plenitude da vida e os conhecimentos e práticas que desviam desse caminho, colocando-se a serviço da morte" (CF, 2008, p. 66).

O sujeito (fiel) ao realizar a performance cognitiva da decisão de se integrar ao sistema proposto de valores, recebe do destinador a sanção cognitiva de reconhecimento e pertença ao sistema de restrições semânticas proposto. Examinemos em seguida certa atitude de perfomance pragmática do sujeito.

249. Quando pensamos em ações em defesa da vida, é importante que nos livremos de qualquer redução moralista do tema, olhando-o em sua globalidade e a partir da experiência do nosso pertencer a Cristo [...].

250. [...] De nossa fé em Cristo nasce também a solidariedade como atitude permanente de encontro, irmandade e serviço. Ela há de se manifestar em opções e gestos visíveis, principalmente na defesa da vida e dos direitos dos mais vulneráveis e excluídos, e no permanente acompanhamento em seus esforços, por serem sujeitos de mudança e de transformação de sua situação [...].

251. [...] Entendemos, além disso, que a verdadeira promoção humana não pode se reduzir a aspectos particulares: deve ser integral, isto é, promover a todos os homens e a todo homem, a partir da vida nova em Cristo que transforma a pessoa de tal maneira que a faz sujeito de seu próprio desenvolvimento (CF, 2008, p. 98).

O enunciado propõe a prática das seguintes "ações desenvolvidas na defesa da vida humana, numa visão integral de pessoa" (CF 2008, p.98), expostas mediante os subtítulos das seções que compõe a terceira parte do enunciado: a) "desenvolver a espiritualidade da vida"; b) "conscientizar por meio de uma educação afetivo-sexual integral"; c) "conscientizar para o valor da família"; d) "incentivar a reflexão nos ambientes acadêmicos, científicos e técnicos; e) "atuar junto aos meios de comunicação social"; f) "acolher a gestante em dificuldade e seu 
filho"; g) "apoiar os menores em situação de risco; h) "trabalhar junto às pastorais desenvolvendo a ação em defesa da vida”.

Essas ações se materializam na última seção, por meio de um gesto concreto: "Coleta da Solidariedade: Gesto Concreto de Fraternidade" (CF 2008, p.115).

Realiza-se, portanto, a performance pragmática do sujeito (execução). No que concerne à estrutura modal do fazer, observamos, nessa seção, o "programa narrativo do sujeito competente e em ação" (GREIMAS; COURTÉS, 2008, p. 364).

A identidade enunciativa se estabelece no enunciado por meio da produção do objeto cognitivo: o enunciado CF 2008. Verificamos a presença de um tom didático e da postura professoral na exposição da explicitação da doutrina, o que constitui a imagem do mestre, do conhecedor das Escrituras e dos documentos da Igreja. A isso podemos acrescentar a imagem de um éthos racionalista e da postura de um intelectual cristão preocupado com os problemas enfrentados pela sociedade.

A assimilação de simulacros das imagens ditadas pela crença refere-se aos diferentes modos de pensar o mundo, relacionados aos interesses de grupos sociais postos em confronto e ligados à instituição religiosa que os legitima.

Temos, desse modo, a possibilidade de ressemantização de um tema como a defesa da vida divina. A defesa da vida, no que diz respeito à temática da proteção e defesa da vida divina, terá os semas retomados e alterados ao passar de uma totalidade para outra.

Verificamos a polêmica ressurgida entre duas totalidades discursivas, na medida em que cada uma delas tematiza e figurativiza o mundo de maneira contraditória, para construir, cada qual, o mundo segundo representações homogeneizadas ou cindidas e, por conseguinte, heterogêneas: a) ética relativista, figurativizada pelas diferentes formas de violência e atentados contra a vida, em especial contra a pessoa humana; b) ética católica: temática do valor inviolável da vida humana (visão integral da vida e da pessoa humana)

Estabelece-se, nesse sentido, a relação polêmica entre o éthos da defesa da vida humana, caracterizado pela "visão integral que não deve levar à censura do corpo, com todas as suas manifestações biopsíquicas, mas considerar a pessoa numa unidade que leva em conta todas as suas inclinações biológicas e espirituais" (CF 2008, p. 67) e o antiéthos (cultura da morte) pautado pela lógica relativista da sociedade contemporânea, ao apresentar "visão redutiva da pessoa humana, que considera que apenas aquilo que é instintivo seria natural”. O éthos da CF-2008 só se constitui por oposição ao outro (ética relativista), pelo embate de duas 
posições determinadas pelo ressurgimento da polêmica. $\mathrm{O}$ diálogo de ataque unilateral estrutura o éthos da CF-2008, ao reavivar e reconstruir o antiéthos relativista dentro de seu próprio sistema de restrições semânticas como um simulacro a ser rechaçado.

Os valores católicos de defesa da vida veiculados por esse objeto-discurso (texto base da CF) são propostos pela enunciação divulgadora, no papel actancial de um destinadormanipulador, cujos ideais, postos como objeto de valor a serem partilhados com o enunciatário, são compatíveis à formação discursiva católica. Esse mesmo sujeito da enunciação, no papel também de agente de prestígio vinculado à $\mathrm{CNBB}$, dentro do campo discursivo católico, tem seu fazer reconhecido: a exposição da matéria de fé e moral deve ser executada e praticada pelos membros participantes e cúmplices da formação discursiva considerada.

\subsection{Divulgação religiosa propagandista ${ }^{67}$}

O que se tem, enfim, é a busca, por parte das instituições, de legitimação perante a sociedade, a fim de divulgar suas ideologias. Os bens em jogo são de duas espécies: os simbólicos, referentes à satisfação mental-espiritual, e os bens materiais, dos quais depende o funcionamento da instituição religiosa.

Luís Mauro Sá Martino ${ }^{68}$

No que tange à especificação da tipologia proposta nesta tese como discurso de divulgação religiosa para conversão (propagandista), tomamos como corpus o gênero compêndio didático de estudo bíblico, enquanto um gênero de divulgação religiosa. Procedemos ao recorte da unidade quinze "A adoração que Deus aprova" $\left(\mathbf{T 1 2}^{69}\right)$, extraída do livro $O$ que a Bíblia realmente ensina, publicado pela Sociedade Torre de Vigia de Bíblias e Tratados e pertencente à formação discursiva das Testemunhas de Jeová ${ }^{70}$ (doravante TJ).

\footnotetext{
${ }^{67}$ Entendemos por propaganda o "conjunto de técnicas e atividades de informação e de persuasão, destinadas a influenciar as opiniões, os sentimentos e as atitudes do público num determinado sentido. Ação planejada e racional, desenvolvida através dos veículos de comunicação, para divulgação das vantagens, das qualidades e da superioridade de um produto, de um serviço, de uma marca, de uma ideia, de uma doutrina, de uma instituição etc" (RABAÇA; BARBOSA, 1987, p. 481).

${ }^{68}$ Martino (2003, p. 11-12).

69 T12 refere-se à indicação do texto, tal como ele consta no exemplar "Anexos" e que constitui o segundo volume desta tese.

${ }^{70}$ As Testemunhas de Jeová tiveram início na década de 1870. Inicialmente chamadas de "Estudantes da Bíblia", adquiriram a denominação de Testemunhas de Jeová em 1931. Com um pensamento religioso de forte cunho
} 
Dirigido à população em geral, o compêndio didático $O$ que a Bíblia realmente ensina se apresenta como um curso de estudo bíblico, um manual de instrução fundamental da doutrina das $\mathrm{TJ}^{71}$, a ser utilizado no trabalho de evangelização voluntária realizado por essa instituição religiosa, cujo objetivo é fazer novos discípulos. O compêndio se mostra, portanto, um instrumento de pregação e de ensino no qual se abre a possibilidade para que se possa conhecer aquilo que essa instituição professa, celebra e prega em sua doutrina cotidiana.

Ele se constitui, dessa forma, como um manual para aqueles que desejam saber mais sobre a doutrina das TJ e obter um "bom conhecimento" da "verdade" bíblica ${ }^{72}$. Esse enunciado tem por objetivo fundamental procurar levar o fiel a cultivar a personalidade cristã ressaltada como verdadeira por essa formação religiosa ${ }^{73}$. Enfatizamos aqui o caráter desse "bom conhecimento" ancorado no ponto de vista do enunciador responsável por essa formação religiosa.

Procuramos destacar, a seguir, os mecanismos argumentativos de que o enunciador do compêndio se utiliza, na medida em que, ao se constituir como um texto instrucional de divulgação religiosa (divulgação propagandista), tem por objetivo primordial persuadir e convencer seu enunciatário da veracidade do sistema de valores das TJ por oposição aos valores partilhados por outro sistema de valores cristãos.

milenarista e nominalista, as Testemunhas de Jeová tiveram a sua fundação no início do século XIX em 1881 por Charles-Taze Russel (1852-1916) nos Estados Unidos.

${ }^{71}$ Para um estudo mais aprofundado das características constituintes da formação discursiva em análise nos remetemos ao nosso estudo anterior: Ramos-Silva (2007).

72 “As Testemunhas de Jeová consideram praticar a única religião verdadeira (o primitivo Cristianismo) e, por isso, possuem uma configuração interdiscursiva, em que polemizam com relação às organizações religiosas consideradas biblicamente erradas em suas doutrinas e práticas nesse contexto" (RAMOS-SILVA, 2007, p. 62).

73 “As Testemunhas de Jeová baseiam as próprias crenças na Bíblia, tida como palavra de Deus, com a consideração de seus 66 livros como divinamente inspirados e historicamente corretos. Tomam o Novo Testamento por Escrituras Gregas Cristãs e o Velho Testamento por Escrituras Hebraicas. Fundamentadas e baseadas nesses dois escritos, afirmam interpretar a Bíblia literalmente, com exceção das situações em que o contexto indique se tratar de conteúdo figurativo ou simbólico. A tradução utilizada pelas TJ é a Tradução do Novo Mundo das Escrituras Sagradas, publicada pela Torre de Vigia. O texto bíblico é interpretado e aprovado pelo Corpo Governante das Testemunhas de Jeová. Esse Corpo Governante é um órgão central das Testemunhas de Jeová formado por homens experientes, comumente designados anciãos e considerados "porta vozes" de Jeová a fim de difundir sua doutrina e ensinos bíblicos adequados. A interpretação do texto bíblico é publicada pela Sociedade Torre de Vigia de Bíblias e Tratados” (RAMOS-SILVA, 2007, p. 59). 


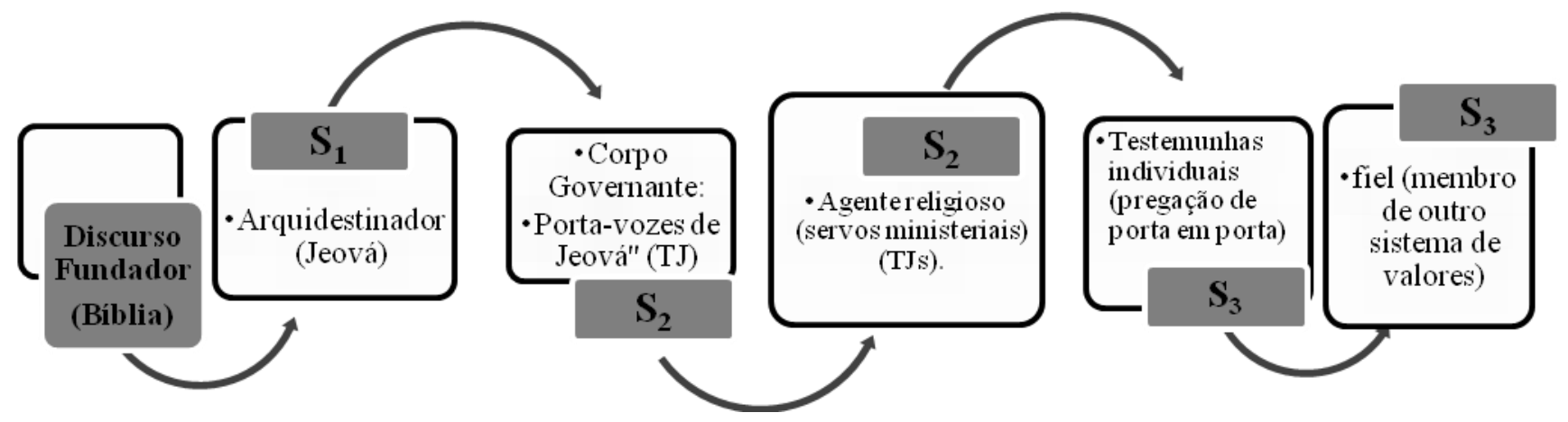

Figura 18. Divulgação propagandista $\left(\mathrm{TJ}_{\mathrm{s}}{ }^{74}\right)$.

Vejamos como essa instituição discursiviza o perfil do enunciatário desse gênero textual:

O fato de estar lendo este livro mostra que você quer saber o que a Bíblia ensina. O livro vai ajudá-lo. Note que, ao pé da página, há perguntas relacionadas aos parágrafos. Milhões de pessoas que estudam a Bíblia com as Testemunhas de Jeová gostam do método de perguntas e respostas. Esperamos que você também goste, e que receba as bênçãos de Deus à medida que sentir a emoção e a alegria de aprender o que a Bíblia realmente ensina! (O QUE A BÍBLIA REALMENTE ENSINA, 2006, p. 7).

O enunciador do compêndio discursiviza o enunciatário como aquele detentor da modalidade do querer-saber o que a "Bíblia realmente ensina", saber esse necessário à aquisição do objeto valor "graça divina", figurativizado no enunciado pelas bênçãos de Deus.

\footnotetext{
74 “As Testemunhas de Jeová apresentam uma forte organização hierárquica e piramidal. A sede mundial das Testemunhas de Jeová está situada no Brooklyn, Nova York, EUA. Nela se encontra o corpo governante (grupo central de anciãos experientes que tem por função supervisionar a congregação mundial). O corpo governante é responsável pelo envio de representantes a várias regiões do globo, para que possam conferenciar com os representantes das filiais ou congêneres dessas regiões. Em cada uma dessas filiais, ou congêneres, encontra-se uma comissão de filial, composta de três a sete membros, com a finalidade de supervisionar a obra nos países que se encontram sob sua jurisdição. Cada país ou região, tendo uma filial ou congênere que o supervisione, é dividido em distritos e esses, posteriormente, são divididos em circuitos, tendo cada um deles seu representante. Para cada circuito, há cerca de 20 congregações com a realização de duas assembléias anuais para cada circuito. As congregações locais são denominadas de Salões do Reino, responsáveis pela proclamação das Boas Novas na comunidade. Para cada congregação, temos a presença de anciãos ou superintendentes que tomam a dianteira no ensino da congregação. Esses recebem a ajuda de servos ministeriais. As regiões destinadas para cada congregação são divididas em pequenos territórios designados a Testemunhas individuais, empenhadas na realização de sua missão de divulgação de porta em porta" (RAMOS-SLVA, 2007, p. 61-62).
} 
Ressaltamos o destaque em itálico presente no enunciado que faz sobressair o caráter do conhecimento bíblico proposto e tido como verdadeiro por essa formação discursiva.

Verificamos também, ainda nesse parágrafo, a apresentação da composição diagramática do enunciado, no qual os estudos bíblicos são apresentados mediante a estrutura de perguntas e respostas, por meio de um entrelaçamento diagramático dado no plano de expressão (PE): as respostas das perguntas dispostas na nota de rodapé são indicadas numericamente no enunciado principal do compêndio.

A utilização desse mecanismo de projeção dos atores da enunciação, a partir da instauração de perguntas e respostas (P-R), exibe um efeito de realidade ou referente, com a ilusão de uma situação real de interação conversacional empregada no curso de estudo bíblico.

O próprio enunciador, por intermédio do uso da pergunta retórica como recurso argumentativo, procura responder em seu enunciado à seguinte questão: "Como é possível saber qual é a maneira correta de adorar a Jeovác"75"? Ao que ele responde "Não é preciso estudar e comparar os ensinos de todas as muitas religiões. É preciso apenas aprender o que a Bíblia realmente ensina a respeito da adoração verdadeira" (grifos no original).

Outro recurso argumentativo empregado pelo enunciador, a fim de que o enunciatário adquira a competência da adequada identificação da "adoração verdadeira" e que situe a sua argumentação no tempo de uma prática discursiva de conversão, é a ilustração.

$\underline{2}$ Como é possível saber qual é a maneira correta de adorar a Jeová? Não é preciso estudar e comparar os ensinos de todas as muitas religiões. É preciso apenas aprender o que a Bíblia realmente ensina a respeito da adoração verdadeira. Para ilustrar: em muitos países, existe o problema da falsificação de dinheiro. Se você fosse encarregado de identificar dinheiro falso, como faria isso? Memorizando todos os tipos de falsificações? Não. Seu tempo seria melhor gasto se você o usasse para estudar o dinheiro legítimo. Depois de conhecer bem

\footnotetext{
${ }^{75}$ Conforme ressaltamos em estudo anterior (RAMOS-SILVA, 2007, p.58), existem duas formas possíveis de dizer o nome de Deus, que em hebraico é impronunciável, através da vocalização das consoantes que formam o tetragrama YHWH. A forma Yahweh derivou-se pela vocalização utilizando-se as vogais de adonai, "meu senhor", em hebraico. No entanto, havia variantes da forma de dizer, o que levou à outra forma de vocalização das consoantes, derivando o nome Yehowah, chegando até Jeová. O caráter oriundo do nominalismo filosófico apregoa que a nomeação é condição de existência, ou seja, para que algo adquira sua existência "real" deve ser nomeado. Dessa forma, as TJ utilizam-se do tetragrama hebraico YHWH (Yahweh) como representação e demonstração da denominação de Deus como Jeová. Eles justificam essa denominação com apoio do pensamento nominalista, para o qual algo, para ser entendido, compreendido e aceito deve ser nomeado.
} 
o dinheiro legítimo, poderia reconhecer o falso. Do mesmo modo, quando aprendemos a identificar a religião verdadeira, podemos reconhecer as que são falsas (O QUE A BÍBLIA REALMENTE ENSINA, 2006, p. 144).

De acordo com Perelman e Olbrechts-Tyteca (2005, p. 407), o mecanismo argumentativo da ilustração "tem a função de reforçar a adesão a uma regra conhecida e aceita, fornecendo casos particulares que esclarecem o enunciado geral", aumentando, assim, a presença na consciência.

Dessa maneira, o enunciador dessa formação discursiva utiliza-se desse mecanismo argumentativo com o intuito de reforçar a adesão do enunciatário à aquisição da competência necessária mediante o aprendizado do que a Bíblia realmente ensina a respeito da "adoração verdadeira". Uma regra abstrata como a identificação da "adoração verdadeira" é concretizada por meio de um caso particular, os mecanismos pelos quais é possível se reconhecer o "dinheiro legítimo".

Para que o enunciatário desenvolva a performance cognitiva da decisão, que deve culminar com a aquisição da competência necessária à adequada identificação da religião verdadeira, TJ, e posterior adesão a ela, o enunciador faz uso, também, de outro procedimento argumentativo, a citação de autoridade. Para tanto, tendo como base a argumentação utilizada pelo mecanismo da ilustração, segundo a qual o enunciatário deveria adquirir o saber necessário à identificação do "dinheiro legítimo", pela aquisição da identificação das características constituintes de sua veracidade, são apresentados no enunciado os seis aspectos necessários ao enunciatário para a identificação daqueles que praticam a "religião verdadeira". Por intermédio do recurso argumentativo da citação de autoridade do enunciado fundador bíblico, o enunciador procura atestar e comprovar esses aspectos mediante exemplos extraídos das Sagradas Escrituras.

Vejamos quais são esses aspectos: 1) "Os servos de Deus baseiam seus ensinos na Bíblia"; 2) "Os que praticam a religião verdadeira adoram apenas a Jeová e divulgam seu nome"; 3) "Os do povo de Deus têm amor genuíno e altruísta entre si"; 4) "Os cristãos verdadeiros aceitam a Jesus Cristo como meio de salvação provido por Deus"; 5) Os adoradores verdadeiros não fazem parte do mundo"; 6) "Os verdadeiros seguidores de Jesus pregam que o Reino de Deus é a única esperança para a humanidade" (O QUE A BÍBLIA REALMENTE ENSINA, 2006, p. 146-151). 
Tomemos o primeiro desses aspectos: "os servos de Deus baseiam seus ensinos na Bíblia”. Citações e alusões bíblicas têm por objetivo reforçar o caráter dessa formação discursiva como "verdadeira", dado ser fundamentada, conforme essa formação discursiva, no discurso fundador bíblico.

\footnotetext{
${ }^{6}$ Os servos de Deus baseiam seus ensinos na Bíblia. A própria Bíblia diz: "Toda a Escritura é inspirada por Deus e proveitosa para ensinar, para repreender, para endireitar as coisas, para disciplinar em justiça, a fim de que o homem [ou mulher] de Deus seja plenamente competente, completamente equipado para toda boa obra." (2 Timóteo 3:16, 17) O apóstolo Paulo escreveu aos companheiros cristãos: "Quando recebestes a palavra de Deus, que ouvistes de nós, vós a aceitastes, não como a palavra de homens, mas, pelo que verazmente é, como a palavra de Deus." (1 Tessalonicenses 2:13) Assim, as crenças e as práticas da religião verdadeira não se baseiam em conceitos humanos nem em tradições. Elas se originam da Palavra inspirada de Deus, a Bíblia.
}

O estudo do enunciado teria como objetivo, portanto, fornecer a aquisição do aprendizado necessário (saber) dos requisitos que Deus exigiria dos "verdadeiros cristãos". Diante disso, o enunciatário, deve adquirir o saber a respeito da adequada verdade bíblica, a fim de que possa aprender a adorar a Jeová da maneira correta.

Assim sendo, o enunciado do compêndio, pautado pelo tom injuntivo e pelas modalidades deônticas, procura descrever uma série de instruções e comportamentos regrados e recorrentes, baseadas no discurso fundador bíblico como argumento de autoridade a fim de que o fiel proceda à adequada identificação da "religião verdadeira".

A doação do saber é modalizada segundo o ponto de vista veridictório: o enunciado de divulgação religiosa oferece parâmetros do parecer e ser cristão.

A figura emblemática e central daqueles que "praticam a religião verdadeira" é determinada pelas modalidades veridictórias, de forma que a imagem traçada para o enunciatário é daquele que parece e é cristão.

Os estados cognitivos (posições cognitivas) do verdadeiro cristão, obtidos graças ao jogo do ser e do parecer, possuem a seguinte articulação, no que diz respeito às modalidades veridictórias: verdadeiro/falso/secreto/mentiroso (GREIMAS; COURTÉS, 2008, p.532). 


\section{verdade}

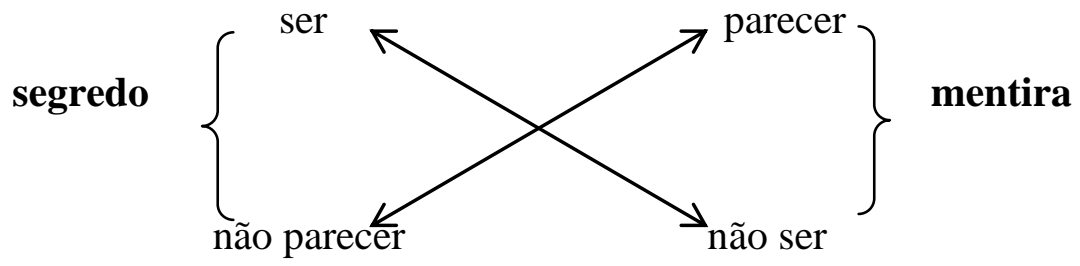

falsidade

O fazer persuasivo, aplicado pelo destinador-manipulador, visa fazer o sujeito manipulado crer no sistema de crenças, pertencente ao sistema de valores das TJ. Tal criação desse sistema é, no entanto, motivada pelo fazer-parecer-verdadeiro. Desse modo, o sujeito do fazer procede ao estabelecimento de efeitos de verdade que procuram levar o enunciatário a crer nos valores e ideais propostos pelo enunciado, fazendo com que ele creia serem, tais valores, os verdadeiros. Todo o processo de fazer-crer, é importante ressaltar, dá-se mediante uma performance cognitiva.

O enunciatário, por conseguinte, deve realizar um fazer interpretativo da manipulação exercida pelo destinador-manipulador (fazer-crer verdadeiro). Tal fazer interpretativo é realizado pelo julgamento epistêmico do crer. Dessa forma, ele deverá considerar os valores propostos como certamente verdadeiros: crer-ser (certeza) e parecer.

O destinatário-sujeito, desejoso dos valores cognitivos necessários para se tornar um verdadeiro-cristão, quer-saber entrar em conjunção com esses valores e integrar-se a eles.

O sujeito, ao realizar a performance cognitiva da decisão de se integrar ao sistema de valores, recebe do destinador a sanção cognitiva de reconhecimento, na qual o sujeito é julgado como cumpridor do contrato e pertencente ao sistema de restrições semânticas proposto. Por meio da instauração dessa cena enunciativa, o enunciador transmite o saber, caracterizado pela modalidade veridictória como o "saber verdadeiro", por oposição ao considerado "falso" pelo julgamento do enunciador. À medida que esse enunciador vai apresentando os argumentos, ele vai dizendo: temos o "saber verdadeiro". Entretanto, o éthos se explicita na enunciação enunciada, nas marcas da enunciação deixadas no enunciado (FIORIN, 2004, p. 120). A lição instrucional, ao operar com a dimensão da enunciação informativa dos saberes de crença, pretende fazer com que o interlocutário partilhe os 
julgamentos negativos que estabelece em relação às crenças e costumes considerados errôneos e falsos, pois seriam, segundo essa formação discursiva, originários de "religião falsa".

O enunciador, mediante a seção final da lição "O que você fará", força o enunciatário a tomar uma posição com relação ao saber que lhe foi transmitido, com a posterior adesão ao sistema de valores proposto.

\section{O QUE VOCÊ FARÁ?}

${ }^{15}$ Simplesmente crer em Deus não é suficiente para agradá-lo. Afinal, a Bíblia diz que até os demônios crêem que ele existe. (Tiago 2:19) Mas eles, obviamente, não fazem a vontade de Deus e não têm sua aprovação. Para sermos aprovados por Deus, não só temos de crer na sua existência, mas também fazer a sua vontade. É preciso também cortar os laços com a religião falsa e aceitar a adoração verdadeira (O QUE A BÍBLIA REALMENTE ENSINA, p. 151).

O enunciatário, tendo realizado a adesão ao sistema de valores proposto, deveria efetuar a passagem do saber considerado "falso" ao saber "verdadeiro". Temos, dessa forma, a instauração da distensão propriamente dita, e que determina, no nível narrativo, o abandono dos programas desenvolvidos, até então, pelo sujeito e o seu ingresso na rota desejada pelo destinador.

As crenças partilhadas anteriormente pelo actante sujeito (cristão) são axiologizadas com o valor do repudiável e indesejável a esse sistema de valores, pois, de acordo com esse discurso, seriam originárias de religiões falsas, ou pertencentes a outros ensinos bíblicos.

Depreendemos a narrativa de transformação de estados do sujeito cristão, que inicialmente conjunto com o $\mathrm{O}_{\mathrm{v}}$ "saberes originários de religiões falsas", busca, por meio do estabelecimento de um programa de privação, renunciar o contrato anterior e entrar em conjunção com o contrato vigente para pertencer ao sistema de valores proposto pelas TJ.

Caracteriza-se essa divulgação como propagandista. Nela o sujeito é manipulado a realizar a parada de uma situação anterior de relaxamento, na qual ele estaria conjunto com os valores de uma determinada formação religiosa, sendo integrado, por conseguinte, a um novo sistema de valores. Observamos uma estratégia por intermédio da qual o enunciador, ao fornecer a competência necessária para que o sujeito reconheça e assuma sua posição em favor da "religião verdadeira", utiliza-se de um processo ordenado argumentativamente e regulado no tempo e no espaço. Temos, portanto, a argumentação empregada no tempo de uma prática discursiva, um processo de natureza linguística em uma estrutura temporal e espacial hierarquizada. 


\subsection{Divulgação religiosa midiática}

A mídia religiosa, aliando dois discursos legitimantes, o religioso e o da mídia - um por sua condição de dogma revelado, outro por sua pretensão a uma impossível e indesejável objetividade - , procura reforçar esta ou aquela posição, com o cuidado que tais questões possam ter aparência e relevância doutrinária que justifique sua presença em um veículo religioso.

Luís Mauro de Sá Martino ${ }^{76}$

\subsubsection{O sujeito divulgador no campo discursivo religioso midiático}

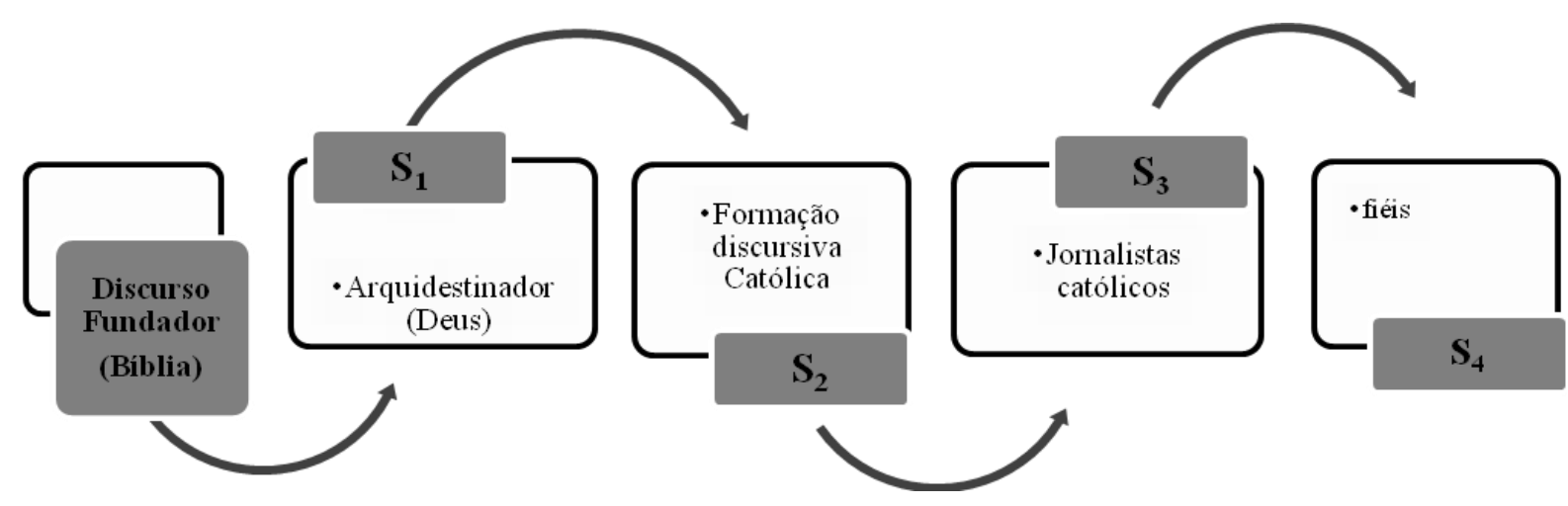

Figura 19. Divulgação religiosa midiática.

No que concerne ao campo religioso de informação midiática, estabelecemos como recorte textual um enunciado de divulgação religiosa: um artigo jornalístico extraído da revista Catolicismo, pertencente à esfera ideológica da religião católica. Partindo do princípio dialógico da linguagem, tal como proposto por Bakhtin (2003), reconhecemos o sujeito da enunciação constitutivamente dialógico.

Buscar-se-á, no recorte analítico proposto, definir, como objeto de pesquisa, o diálogo presente no enunciado de divulgação religiosa entre duas esferas ideologicamente constituídas (ciência e religião) no que concerne à temática a respeito da pesquisa envolvendo células-

\footnotetext{
${ }^{76}$ Martino (2003, p. 56).
} 
tronco embrionárias. Ao observar as recorrências dos mecanismos de construção do sentido dos textos, refletimos sobre a noção de discurso de "divulgação religiosa" e de "divulgação científica", que permeia o espaço discursivo das esferas em confronto, e que é pertinente a cena enunciativa partilhada em que se propõe um fazer-crer e um fazer-saber peculiar, seja a palavra revelada, seja às descobertas de origem científica.

Para que possamos estabelecer a caracterização do gênero artigo jornalístico de divulgação religiosa, presente no campo religioso de informação midiática, tomamos como base o texto "29 de maio de 2008: dia trágico na história do Brasil", publicado na seção SOS Família, extraído da revista Catolicismo, pertencente à esfera ideológica Católica (T13).

Observamos, portanto, como se dá a argumentação entre os campos discursivos de divulgação religiosa e científica. Consideramos o enunciado de divulgação religiosa apoiado em seus pontos de vista, de acordo com a ideologia da instituição.

Vemos, por meio da análise realizada, como são construídos, no enunciado, o conjunto de posicionamentos e, por conseguinte, o diálogo entre os campos discursivos (divulgação religiosa/ científica). Verificamos como esse dialogismo é determinado pela atitude responsiva, discordância, controvérsia, ética e tomada de posição com relação ao tema das configurações discursivas, estabelecida no próprio texto. Tudo gravita em torno do núcleo temático-figurativo: as células-tronco.

Constatamos, assim, como são instituídas, no enunciado, as perspectivas da esfera ideológica católica defendidas pela revista. Percebemos como se articula, mediante recursos composicionais que fundam o estilo, a relação entre a palavra alheia, representada pelo diálogo entre duas esferas ideologicamente constituídas (ciência e religião), em um enunciado de divulgação religiosa: um artigo jornalístico extraído da revista Catolicismo, pertencente à esfera ideológica da religião Católica. Veremos emergir duas concepções diferenciadas, religiosa e científica, no que diz respeito à temática das células-tronco embrionárias.

Segundo Grillo (2006, p. 145-146), as esferas são determinantes para a compreensão da palavra alheia, pois a relação do tema com seu referente é condicionada pelo campo de comunicação discursiva.

Atentaremos, a seguir, a como o diálogo com os elos precedentes, denominados interdiscurso e intertexto, processa-se no enunciado, mediante o condicionamento motivado pela identidade temática e as coerções do campo de divulgação religiosa contemplada. 
O enunciado do artigo jornalístico de divulgação religiosa constitui-se levando em consideração as atitudes responsivas em função das quais ele se origina. Ele tanto responde àqueles que partilham de um ponto de vista contrário à crença e moral católicas de defesa da vida, quanto se antecipa àqueles que futuramente podem lhe responder. Construindo-se, por conseguinte, em função dessa resposta, antecipa-se a ela.

Além disso, o enunciado tem como elemento constitutivo um direcionamento a um enunciatário presumido que deve ser partidário dos mesmos valores. Segundo Bakhtin (2003, p. 302), a consideração do destinatário irá determinar a escolha do gênero do enunciado, dos procedimentos composicionais e dos recursos linguísticos, ou seja, do estilo do enunciado.

$\mathrm{O}$ artigo jornalístico de divulgação religiosa recortado se insere no suporte revista que, segundo Rabaça e Barbosa (1987, p. 516), caracteriza-se como uma "publicação periódica que trata de assuntos de interesse geral ou relacionados a uma determinada atividade ou ramo do conhecimento (literatura, ciência, comércio, política etc.)”.

A revista Catolicismo, redigida "por uma equipe altamente capacitada de jornalistas católicos", assinala-se como um veículo impresso, de periodicidade mensal. Essa revista relaciona-se à lógica do campo religioso católico no qual se insere, e que determina, portanto, a posição do sujeito nesse campo. Ela tem como objetivo exercer uma influência educativa e uma formação moral e cultural sobre seus leitores que devem partilhar dos mesmos valores presentes na formação discursiva em que a revista se insere. A revista se apresenta como "porta voz da TFP"77". O próprio título da seção em que o artigo se insere, seção "SOS Família", pressupõe a defesa de valores da doutrina católica, em oposição a uma "lógica da cura" estabelecida pelas pesquisas científicas não comprometidas com valores éticos e morais.

A divulgação religiosa midiática possui as mesmas características que o discurso científico da esfera midiática, sendo submetida às próprias coerções desse campo: contemporaneidade, periodicidade, objetividade, informatividade e adesão do enunciatário. Veremos como essas coerções caracterizam o gênero artigo jornalístico de divulgação religiosa. Aliados a esses elementos, explicitamos quais são os principais recursos estilísticocomposicionais empregados para a organização do conteúdo semântico-objetal do enunciado,

\footnotetext{
77 “Organização ligada a extrema direita da Igreja católica, que se destaca por suas ideias conservadoras" e que tem por objetivo "defender a ortodoxia dos ensinamentos doutrinários da Igreja Católica, Apostólica, Romana” (MEDEIROS, 2004, p. 3-16).
} 
bem como as formas empregadas para incorporação, apreensão e contestação do discurso alheio.

A contemporaneidade do enunciado constitui-se por meio da utilização da seguinte temática: a questão envolvendo as células-tronco embrionárias motivada por um fato político - a votação de um projeto de lei. O artigo jornalístico presente na edição de julho da revista expõe, portanto, um fato contemporâneo a sua realização: a votação do artigo $5^{\circ}$ da lei de Biossegurança no Supremo Tribunal Federal, com a consequente aprovação das pesquisas com células-tronco embrionárias, realizada em 29 de maio de 2008.

O debate moral envolvendo o uso de embriões em pesquisas divide-se entre: a) o campo científico, com a busca permanente pelo desenvolvimento técnico-científico; b) o campo jurídico/ Estatal, segundo o qual são considerados a Constituição e o Direito Civil na defesa dos direitos do nascituro, associados à necessidade de uma legislação que regulamente tais práticas genéticas; c) o campo religioso, com a busca e preservação de determinados valores e princípios tradicionais advindos de uma entidade superior e inquestionável (palavra autoritária).

Nos textos jornalísticos, o efeito de objetividade é produzido por meio de recursos enunciativos que procuram conferir efeito de sentido de imparcialidade, conforme os quais os assuntos noticiados seriam independentes da instância jornalística que os veicula. Essa informatividade e ilusão de objetividade se constituem no enunciado pela predominância da terceira pessoa.

Também se observa, como efeito de objetividade, a utilização do discurso citado, com a presença de atores com legitimidade social para abordar o tema em questão, o que confere um efeito de sentido de realidade e duplicação do real ao enunciado:

A deplorável votação no STF parece interpretar a Constituição como não reconhecendo o direito à vida senão depois do nascimento. [...] É o que, por exemplo, afirma a renomada pesquisadora e médica Dra. Alice Ferreira Teixeira : "Está demonstrado pela ciência que a origem do ser humano se situa no momento da concepção [...]”. (CAMPOS, 2008, p. 40).

No excerto anterior, a voz do ator social, a "renomada pesquisadora e médica Dra. Alice Teixeira Ferreira”, embora não seja pertencente à comunidade religiosa, apresenta-se como uma autoridade legítima e reconhecida pela comunidade. Ela partilha os mesmos valores da comunidade católica, com a defesa de um ponto de vista contrário às pesquisas de células-tronco embrionárias. Verifica-se, portanto, por meio da utilização da articulação 
composicional obtida mediante o uso das aspas que circundam o discurso do outro, uma forma convergente de relação dialógica, na medida em que há a defesa do mesmo ponto de vista adotado pela esfera religiosa de divulgação. Desse modo, percebemos a presença do estilo linear, uma vez que é possível demarcar, por intermédio das aspas, o discurso do jornalista e a fala do cientista. Delimitam-se, assim, tanto os discursos convergentes, citados como argumento de autoridade, por apresentarem valores partilhados com a comunidade católica, quanto aqueles com os quais se pretende polemizar.

$\mathrm{Na}$ divulgação religiosa, no entanto, também podemos notar a presença de um efeito de sentido de subjetividade. As especificidades desse campo discursivo, mais do que simplesmente noticiar os argumentos de forma ilusoriamente imparcial, sem posicionamento, caracteriza-se por uma linha editorial doutrinária, cujo enunciado procura realizar a adesão do leitor ao ponto de vista defendido.

Constatamos, no excerto a seguir, um elemento característico do estabelecimento de um efeito de sentido de subjetividade, com a utilização do "nós" inclusivo, que tende a apagar a assimetria entre o autor-jornalista (detentor do saber) e o leitor (que procura a informação).

Entretanto, não temos a menor dúvida em afirmar que foi um dia sinistro e triste para a história de nosso País (CAMPOS, 2008, p. 40, grifos nossos).

Cabe ressaltar que essa revista possui um público-alvo mais restrito, por ter seu meio de difusão realizado, sobretudo, por meio de assinaturas. Por isso, classificamos o texto como artigo jornalístico de divulgação religiosa especializada. Ele apresenta um público-alvo homogêneo, mais restrito, da comunidade católica que partilha das mesmas crenças e valores propugnados no enunciado. Isso explica também o consenso, obtido mediante a utilização do "nós" inclusivo que confirma a presença de um conteúdo temático amarrado pela posição valorativa da esfera religiosa.

A esfera da revista Catolicismo caracteriza-se como híbrida. Nela há elementos da esfera jornalística e religiosa. Além de o próprio enunciado ser de autoria de um jornalista (Paulo Roberto Campos), verificamos também a citação e a referência às fontes midiáticas como argumento de autoridade. Como exemplo, temos, a seguir, a citação de algumas fontes midiáticas em alguns trechos extraídos de um artigo jornalístico publicado na "Folha de S. Paulo" (28-5-08), intitulado A Constituição e as células-tronco adultas, do Prof. Ives Gandra da Silva Martins, jurista e professor emérito da Universidade Mackenzie, partidário dos mesmos valores dessa formação. 
A Constituição brasileira declara, no caput do artigo $5^{\circ}$, que o direito à vida é inviolável; o Código Civil, que os direitos do nascituro estão assegurados desde a concepção (artigo $2^{\circ}$ ); e o artigo $4^{\circ}$ do Pacto de São José, que a vida do ser humano deve ser preservada desde o zigoto. $\mathrm{O}$ argumento de que a Constituição apenas garante a vida da pessoa nascida - não do nascituro - e que nem sequer se poderia cogitar de 'ser humano' antes do nascimento, é no mínimo curioso: retira do homem a garantia constitucional do direito à vida até um minuto antes de nascer e assegura a inviolabilidade desse direito a partir do instante do nascimento. De rigor, a Constituição não fala em direito inviolável à vida em relação à pessoa humana, mas ao ser humano, ou seja, desde a concepção (CAMPOS, 2008, p.42-43).

Observamos a referência desse enunciado a gêneros de esferas distintas. Há, portanto, a incorporação de gêneros intercalados da esfera do direito (constituição, código civil); da esfera científica (conferência); da esfera midiática (artigo jornalístico); da esfera religiosa (salmo, discurso fundador bíblico - Gn 3,5) e de divulgação religiosa (documento autorizado da Congregação para a Doutrina da Fé - instrução).

$\mathrm{O}$ artigo em análise distingue-se como um enunciado verbo-visual com a presença de fotografias ${ }^{78}$ dos ministros e juristas, durante a votação do artigo $5^{\circ}$ da lei de Biossegurança: a) fotografia do ministro Marco Aurélio Mello, do Supremo Tribunal Federal, no momento de seu voto no julgamento da constitucionalidade do artigo $5^{\circ}$. da Lei de Biossegurança; b) fotografia dos juristas Ives Gandra Martins e Cláudio Fonteles em meio à votação no Supremo Tribunal Federal (STF) sobre o uso de células-tronco embrionárias em pesquisas científicas. Essas fotografias, por inserir a espacialização da seção de votação no Supremo Tribunal Federal, conferem um efeito de sentido de objetividade, ao transferirem o leitor ao espaço-tempo em que se deu a aprovação do projeto de lei.

Verificamos também a presença do personagem individualizado do cientista, por meio da fotografia da pesquisadora Natália López Moratalla, catedrática de Bioquímica da Universidade de Navarra. Mediante essa ilustração, tem-se a representação do corpo exterior do cientista. A fotografia destaca o prestígio e competência do cientista em seu local de trabalho. Há, portanto, a valorização do fazer-científico comprometido com a ética, segundo a concepção da esfera religiosa na qual se insere a revista Catolicismo.

\footnotetext{
${ }^{78}$ Ressaltamos que, embora estejamos tratando de enunciados sincréticos, devido aos objetivos desta tese, optamos por não realizar a análise das fotografias e ilustrações que acompanham as reportagens que compõe a divulgação religiosa midiática.
} 
Há também a representação do discurso do outro, das pesquisas embrionárias, por intermédio da fotografia do corpo da ovelha Dolly, "a primeira ovelha clonada", e das células tronco (Cf. A, fig. 4, p. 147).

$\mathrm{O}$ enunciado utiliza também a estrutura de perguntas e respostas como recurso de articulação composicional. Simula-se, por meio delas, o processo interacional do texto: o diálogo com o leitor, partidário dos mesmos valores que o autor-jornalista (enunciador).

De acordo com Bakhtin/Volochinov (2004, p. 123):

Toda a palavra usada na fala real possui não apenas tema e significação no sentido objetivo, de conteúdo, desses termos, mas também um acento de valor ou apreciativo, isto é, quando um conteúdo objetivo é expresso (dito ou escrito) pela palavra viva, ele é sempre acompanhado por um acento apreciativo determinado. Sem acento apreciativo, não há palavra.

Vejamos como esse acento de valor apreciativo é transmitido mediante uma entonação expressiva, conforme a qual a presença do outro é identificável por determinadas marcas linguísticas. Percebemos, nesse sentido, como se constitui o contraste de ideias entre o ponto de vista defendido e o rechaçado pelo enunciado. Desse modo, podemos observar como as articulações composicionais do título e dos intertítulos explicitam a presença da palavra alheia.

Comecemos pela análise do título "29 de maio de 2008: dia trágico na história do Brasill”. Por meio dele já se assume a posição valorativa da esfera ideológica católica na qual a revista Catolicismo se insere. O conteúdo temático é assumido pela voz do autor-jornalista, de tal forma que o texto vai sendo amarrado em suas articulações composicionais pela posição valorativa da esfera religiosa. A própria expressão "dia trágico” assinala essa posição valorativa.

Verificamos a presença, no enunciado a seguir, logo abaixo do título, do tom polêmico na própria referência ao outro: "alguns cientistas e instituições pró-aborto, com largo apoio da mídia" como não pretendente à verdade. A própria expressão "propaganda enganosa", em referência aos discursos deste outro é colocada entre aspas.

Para a obtenção do amparo legal às pesquisas com embriões humanos - com a controvertida decisão do STF - alguns cientistas e instituições pró-aborto, com largo apoio da mídia, fizeram "propaganda enganosa", venderam ilusões, e muitos compraram suas falsas promessas (CAMPOS, 2008, p. 40, grifos nossos). 
Como elementos de estrutura composicional característicos do gênero, dado o caráter noticioso da divulgação religiosa midiática especializada, observamos o resultado do projeto de lei aprovado, logo no primeiro parágrafo do texto. A própria apresentação do resultado é revestida pelo tom polêmico, em que se dá o embate entre aqueles que "festejaram tal aprovação, considerando aquele dia como radioso e de grandes esperanças" e dos partidários da formação considerada, inseridos pelo "nós" inclusivo, e que não possuem "a menor dúvida em afirmar que foi um dia sinistro e triste para a história de nosso País" (CAMPOS, 2008, p.40, grifos nossos).

A própria escolha dos recursos gramaticais e fraseológicos adotado pelo enunciado reflete, por meio da entonação expressiva empregada, o posicionamento contrário às pesquisas envolvendo células-tronco embrionárias, tal como destacamos em alguns exemplos, a seguir:

em controvertida sessão aprovou por 6 votos a 5 as pesquisas com células-tronco embrionárias (CAMPOS, 2008, p. 40, grifos nossos).

Entretanto, não temos a menor dúvida em afirmar que foi um dia sinistro e triste para a história de nosso País (CAMPOS, 2008, p. 40, grifos nossos).

A deplorável votação no STF parece interpretar a Constituição como não reconhecendo o direito à vida senão depois do nascimento (CAMPOS, 2008, p.40, grifos nossos).

Isso corresponde a um verdadeiro atentado contra a Lei natural, a ética e a moral católica (CAMPOS, 2008, p. 40, grifos nossos).

Para sensibilizar e criar forte emoção na opinião pública, e assim influenciar os senhores ministros, não tiveram escrúpulos em fazer uso de deficientes, enganados por falsas promessas de curas (CAMPOS, 2008, p. 42).

Há a presença de poucos intertítulos que, mais do que articular composicionalmente o enunciado, são repletos de entonações expressivas e valorativas a respeito do ponto de vista defendido pelo enunciado, tal como vemos a seguir.

Resolução que abre as portas para a prática do aborto (CAMPOS, 2008, p. 40, grifos nossos). As declarações "salvadoras" antes da votação no STF (CAMPOS, 2008, p. 42, grifos nossos). Verdadeira esperança da medicina: resultados apenas com CTAH (CAMPOS, 2008, p. 42, grifos nossos). 
"A verdade sobre as células embrionárias contras as mentiras divulgadas" (CAMPOS, 2008, p. 43, grifos nossos).

Embriões congelados tornaram-se seres humanos sadios (CAMPOS, 2008, p. 44).

Se a ciência renega o Criador: ela retrocede (CAMPOS, 2008, p. 45).

Os intertítulos expõem o ponto de vista do autor-jornalista que assume os valores da esfera religiosa católica, contrários às pesquisas que violem princípios divinos. Há, nos intertítulos, portanto, a defesa das pesquisas com células-tronco adultas tidas, segundo o enunciado, como a "verdadeira esperança da medicina".

Verifica-se a polêmica na representação do discurso do outro no próprio discurso, por meio da citação do discurso do outro, ao qual não há adesão. O enunciado, a seguir, constróise por meio do estilo linear, de limites precisos, nos quais a alternância dos sujeitos do discurso é estabelecida pelas aspas.

[...] a geneticista Mayana Zatz (da USP) declarou: "Todos vamos nos beneficiar dessa vitória. Temos uma enorme responsabilidade pela frente. Quero deixar claro que não estamos prometendo cura imediata, mas dar o melhor de nós nas pesquisas" (CAMPOS, 2008, p. 42).

Estabelece-se o enquadramento contextual (dialógico) da voz do outro, conforme a qual observamos a relação entre a palavra alheia e o discurso que a enquadra. Notamos a presença da polemização intersubjetiva dentro do campo de divulgação religiosa e até mesmo o diálogo entre campos (divulgação religiosa e divulgação científica). No parágrafo citado anteriormente, mais uma vez, o autor-jornalista adquire o conteúdo temático e a posição valorativa da esfera religiosa, ao pressupor a defesa de valores da doutrina católica em oposição ao que se consideraria uma "lógica da cura" estabelecida pelas pesquisas científicas não comprometidas com valores éticos. Verifica-se, portanto, a utilização palavra bivocal, na qual a presença de um outro discurso é representada no interior do próprio enunciado.

Como mecanismos argumentativos da palavra interiormente persuasiva, empregada pelo autor-jornalista, também se nota uma crítica à mídia, segundo a qual o ponto de vista por ela defendido contraria os valores católicos. A oposição ao ponto de vista do outro "campo midiático" se estabelece na medida em que este, de acordo com o enunciado da revista, estaria distorcendo a realidade por meio do emprego de argumentos infundados e inverossímeis. 
Na mesma ocasião, observou-se também grande atividade midiática de desinformação. Muitas vezes a mídia adulterava os fatos, noticiava sucessos em pesquisas com célulastronco, insinuando que se tratava de células-tronco embrionárias (CTEH), quando os bons resultados tinham sido obtidos a partir de células-tronco adultas (CTAH). (CAMPOS, 2008, p. 42, grifos nossos).

Percebemos também como o discurso do outro é rechaçado, atravessado pela exclusão, na medida em que este seria baseado em "falsas premissas".

Contudo, os seis ministros, fundamentados em falsas premissas (que os embriões congelados não têm vida; que são inviáveis; e que o destino deles era o lixo), concluíram que os embriões não são pessoas humanas (CAMPOS, 2008, p. 43-44).

O discurso do outro, dos seis ministros que aprovaram a lei de Biossegurança com a liberação de pesquisas envolvendo células tronco embrionárias, seria fundamentado "em falsas premissas (que os embriões congelados não têm vida; que são inviáveis; e que o destino deles era o lixo)". O autor-jornalista procede, a seguir, na exposição da argumentação em defesa do ponto de vista conforme o qual "os embriões são pessoas humanas". Faz-se uso, para tanto, da articulação composicional por meio do diálogo em perguntas e respostas, no qual institui a interlocução dialógica com o qual se pretende opor.

Data vênia, os senhores ministros não sabiam que o fato de o embrião estar congelado não é impedimento para que ele dê origem a um ser humano? (CAMPOS, 2008, p. 44).

Discursiviza-se a atitude responsiva entre os dois discursos (do autor-jornalista e dos ministros), segundo a qual o enunciado estabelece uma relação de afirmação-objeção e com os quais pretende polemizar. $\mathrm{O}$ autor-jornalista realiza uma argumentação pautada pela utilização de dados estatísticos extraídos da esfera midiática ou exemplos concretos, de acordo com os quais embriões congelados seriam uma forma de vida humana: "Em uma única clínica no Brasil, a partir de embriões congelados ocorreram 402 nascimentos de bebês, a maior parte acima de três anos de congelamento" (CAMPOS, 2008, p. 44).

O exemplo concreto de Vinícius é corroborado no enunciado pelo argumento de autoridade do Dr. José Gonçalves Franco Junior, médico ginecologista responsável pela clínica onde Vinícius ficou por oito anos congelado em forma de embrião: “É uma loucura falarem que embrião congelado há mais de três anos é inviável. E isso não tem nada a ver com religião. A viabilidade é um fato, e ponto” (CAMPOS, 2008, p,45). 
Como mecanismos argumentativos da palavra interiormente persuasiva empregada pelo autor-jornalista verificamos também a presença da citação da palavra autoritária na defesa do ponto de vista. Observa-se, assim, a atualização do divulgador do conteúdo presente nas Sagradas Escrituras (discurso fundador) à luz da problemática contemporânea.

De qualquer modo, vai ficando claro que há, da parte de alguns, um desígnio malfazejo de substituir-se ao Criador, à maneira do ato de revolta de Lúcifer que quis igualar-se a Deus. Revolta esta que a serpente infernal procurou instilar também nos homens, quando prometeu a Eva: "Sereis como deuses" (Gen. 3,5) (CAMPOS, 2008, p.42).

Por fim, o enunciado termina com a inserção de trechos de um instrumento autorizado da Congregação para a Doutrina da fé, a instrução Donun Vitae, (Instrução sobre o respeito à vida humana nascente e a dignidade da procriação) assinada em 22 de fevereiro de 1987, pelo então Cardeal Joseph Ratzinger (Papa Bento XVI). Percebe-se o prestígio do agente e a posição de poder da esfera ideológica católica e da valorização do veículo instrucional pertencente à doutrina tradicional da Igreja. Observa-se, por meio desse veículo, a vinculação da palavra com a autoridade reconhecida por essa formação ideológica. A palavra autoritária vale por si só, impõe-se independentemente de uma manipulação interior, tal como destacamos, no texto, a expressão "se isso fosse necessário", e caracteriza as coerções desse gênero.

Desde a fecundação tem início a aventura de uma vida humana, cujas grandes capacidades exigem, cada uma, tempo para organizar-se e para encontrar-se prontas a agir. Esta doutrina permanece válida e, além disso, é confirmada - se isso fosse necessário - pelas recentes aquisições da biologia humana, que reconhece que no zigoto [célula resultante da fusão dos núcleos dos dois gametas] derivante da fecundação já está constituída a identidade biológica de um novo indivíduo humano (CAMPOS, 2008, p.44).

Procuramos demonstrar como se processa no enunciado o conjunto de pontos de vista e, por conseguinte, o diálogo entre os campos (divulgação religiosa/ científica), determinado pela atitude responsiva, discordância, controvérsia, ética e tomada de posição com relação ao tema das células-tronco, estabelecida no próprio texto. Os valores católicos de defesa da vida veiculados por esse discurso são propostos pela enunciação divulgadora, no papel actancial de um destinador-manipulador, cujos ideais, postos como objeto de valor a ser partilhados com o enunciatário, são compatíveis à formação discursiva católica. Esse mesmo sujeito da enunciação, no papel também de agente de prestígio vinculado à Revista Catolicismo, dentro 
do campo discursivo católico, tem seu fazer reconhecido: a exposição da matéria de fé e moral deve ser executada e praticada pelos membros participantes e cúmplices da formação discursiva considerada. A formação discursiva, como sistema fundado em figuras e temas de determinado discurso, acaba por esclarecer o lugar do sujeito na polêmica sobre a preservação da vida.

\subsubsection{Relações polêmicas no campo de informação midiática}

O poder coercitivo da instituição revela-se tanto na manutenção de sua ordem interna quanto no combate às instituições concorrentes. Sem significar exclusivamente violência física, o poder coercitivo é sempre uma violência, sob qualquer forma de manifestação, pois condiciona o indivíduo a um comportamento que segue os padrões de expectativa do grupo.

Luís Mauro Sá Martino ${ }^{79}$

\subsubsection{A polêmica do sujeito divulgador no campo discursivo religioso de informação midiática}

Adotamos, para nossa análise, os desenvolvimentos efetuados por Martino (2003) a respeito da midiatização ocorrida no interior do campo religioso, sem que deixem de ser contemplados os trabalhos de Jadon (2005), Maingueneau (2005a), Ramos-Silva (2007) e Silva (2008), a respeito do discurso religioso.

Ressaltamos que nosso objeto de pesquisa é a análise do discurso religioso midiático, não o posicionamento referente a uma ou outra doutrina religiosa contemplada.

Procuramos delimitar dois tipos de concepções polêmicas: a) diálogo polêmico entre uma mesma esfera de sentido; b) diálogo entre esferas na divulgação religiosa. Organizamos um espaço discursivo, com ao menos dois posicionamentos antagônicos sobre uma questão dada. Estabelecemos como recorte, para o primeiro tipo de concepção polêmica, os seguintes textos: a) "Em Recife: tentativa de quebrar a barreira psicológica contra o aborto", presente na seção aborto, extraído da revista Catolicismo, pertencente à esfera ideológica Católica

\footnotetext{
${ }^{79}$ Martino (2003, p.23).
} 
(T14); b) "Médicos contra o Vaticano", que consta na seção Brasil em Xeque, extraído da Folha Universal, veículo de divulgação da Igreja Universal do Reino de Deus (IURD) (T17). No que diz respeito ao diálogo polêmico entre uma mesma esfera de sentido, delimitamos, como espaço discursivo, enunciados de divulgação religiosa de duas totalidades religiosas católicas (TFP-Revista Catolicismo; Movimento dos Focolares - Revista Cidade Nova) e que, supostamente, opõem-se entre si. Estabelecemos como recorte textual, dentro desse espaço discursivo, as seguintes reportagens de capa: "Evolucionismo, criacionismo ou...?" (T16) e "Darwin: evolucionismo anticristão rumo à extinção do homem" (T15), extraídas de duas revistas, respectivamente, Cidade Nova e Catolicismo, ambas pertencentes à esfera ideológica católica.

Define-se o enquadramento contextual (dialógico) da voz do outro, segundo a qual verifica-se a relação entre a palavra alheia e o discurso que o enquadra. Observamos a presença da polemização intersubjetiva dentro do campo/ esfera de divulgação religiosa e até mesmo o diálogo entre esferas (divulgação religiosa e divulgação científica).

Notamos também como o discurso do outro é rechaçado, atravessado pela exclusão, na medida em que este seria baseado em "falsas premissas".

\section{a) O diálogo polêmico entre uma mesma esfera de sentido}

O conteúdo temático das reportagens refere-se à recepção das teorias darwinistas pela esfera ideológica católica, discussão retomada por ocasião dos duzentos anos do nascimento de Charles Darwin.

Vemos emergir duas concepções diferenciadas, no que diz respeito ao modo como cada um dos artigos constrói uma representação da teoria darwinista correspondente a seu próprio universo de sentido.

Buscamos depreender, por meio das relações entre enunciado e enunciação, o modo próprio de ver e perceber o mundo dos sujeitos inscritos em cada uma das formações discursivas contempladas (TFP- Revista Catolicismo; Movimento dos Focolares - Revista Cidade Nova) e que fundamentam cada um dos enunciados extraídos da totalidade discursiva católica. 
Ambas as revistas relacionam-se à lógica do campo/esfera católica na qual se inserem. A revista Catolicismo apresenta-se como "porta voz da TFP", "organização ligada à extrema direita da igreja católica, que se destaca por suas ideias conservadoras" e que tem por objetivo "defender a ortodoxia dos ensinamentos doutrinários da Igreja Católica, Apostólica, Romana" (MEDEIROS, 2004, p. 3-16). A revista Cidade Nova tem como linha editorial ser expressão e divulgação do Movimento dos Focolares, que possui como linha espiritual a proposição de uma "espitiritualidade da unidade", tendo por princípio o estabelecimento do diálogo e da fraternidade entre toda a família humana.

Consideremos alguns excertos extraídos do artigo "Evolucionismo, Criacionismo, ou...?", presente na edição de junho de 2009 da revista Cidade Nova.

Na sua mensagem à Academia Pontifícia para as Ciências, no dia 22 de outubro de 1996, o papa João Paulo II se pronunciou sobre a teoria da evolução e sobre a interação entre fé e ciência. Citou a encíclica "Humani generis", publicada em 1950 por Pio XII, que afirma que não existe oposição entre a evolução e a doutrina da fé acerca do homem e da sua vocação (POMPERMAYER, 2009, p.14).

Como elementos característicos da divulgação religiosa midiática, destacamos a utilização de uma temática contemporânea à edição contemplada: o bicentenário de nascimento de Charles Darwin e a recepção de suas teorias pelo campo religioso. Observamos, ainda, a utilização do efeito de sentido de objetividade (imparcialidade jornalística) por meio do uso da terceira pessoa.

Temos, também, como argumento de autoridade, a referência a um instrumento autorizado, a encíclica Humani generis, publicada em 1950 por Pio XII. Verifica-se, assim, o prestígio do agente e a posição de poder da esfera ideológica católica e da valorização do veículo instrucional pertencente à doutrina tradicional da Igreja. Nota-se, mediante esse veículo, a vinculação da palavra com a autoridade reconhecida por essa formação ideológica.

O reconhecimento da teoria da evolução é corroborada no enunciado pelo argumento de autoridade da voz do ator social, o Prof. Paul Schweitzer, "doutor em Matemática, mestre em filosofia, teólogo e promotor de estudos sobre Cosmologia e Religião: 'a Evolução é amplamente comprovada e a Igreja reconhece isso'." (POMPERMAYER, 2009, p.15).

Consideremos agora os seguintes excertos, extraídos da revista Catolicismo (T15): 
As teorias darwinistas, quando levadas ao seu extremo de negação de Deus e da ordem natural, induzem à aceitação da "cultura da morte": a extinção do homem (DUFAUR, 2009, p. 27).

Veja a religião católica, teólogos que aceitam a evolução, como Teilhard de Chardin. Eles criaram uma nova teologia, viraram a Igreja Católica pelo avesso (DUFAUR, 2009, p. 27).

Darwin passou a confessar-se agnóstico e a menosprezar acintosamente a Religião. Lê-se em sua Autobiografia: "O Antigo Testamento é manifestadamente falso, a Torre de Babel, o arco-íris como sinal, etc" [...] (DUFAUR, 2009, p. 28).

A utopia pós-humana imagina o fim da história natural da humanidade, tal como foi elaborada pela evolução (DUFAUR, 2009, p. 34).

Evidencia-se, ainda, o efeito se sentido de subjetividade. O autor-jornalista instaura-se como interlocutor (a). Esse artigo, mais do que simplesmente noticiar os argumentos de forma imparcial, sem posicionamento, caracteriza-se por uma linha editorial doutrinária, cujo enunciado procura realizar, portanto, a captação do leitor sobre o ponto de vista defendido.

Observamos no enunciado a oposição entre dois percursos figurativos conflitantes: a isotopia da "cultura da morte", com a figura do "evolucionismo anticristão rumo à extinção do homem”, por oposição à cultura da vida, da defesa e da proteção da vida divina.

Verificamos a recorrência na materialidade discursiva da totalidade, a presença dos intertítulos, que, mais do que articular composicionalmente o enunciado, são repletos de entonações expressivas e valorativas a respeito do ponto de vista defendido pelo enunciado, tal como veremos a seguir.

\footnotetext{
Anticristianismo e evolucionismo explicados simultaneamente;

Cascata de conjecturas inverificáveis;

Recusa do sério debate científico;

O "assassinato" da moral confessado por Darwin.
}

Percebemos duas formas de habitar o espaço discursivo que, por sua própria constituição semântica, são polêmicas. Ao éthos da justa medida da Revista Cidade Nova, que procura integrar as noções de evolucionismo e criacionismo, pautado pelo tom informativo e construído pelo efeito de sentido de objetividade e imparcialidade, opõe-se o éthos beligerante da Revista Catolicismo. Este, constituído pela isotopia da guerra, procura combater seu 
inimigo "evolucionismo" rechaçando o ponto de vista defendido por esse "outro" em seu próprio enunciado.

\section{b) O diálogo entre esferas na divulgação religiosa}

O conteúdo temático dos textos recortados refere-se ao caso ocorrido em Alagoinha e Recife (PE), em 25 de fevereiro de 2009, e amplamente noticiado pela mídia, no qual uma menor de nove anos de idade, violentada pelo padrasto, teria ficado grávida de gêmeos; fato que reacendeu o debate sobre o aborto na mídia nacional e internacional.

Verificamos sob a aparente objetividade informativa apregoada pelos textos, como a própria escolha dos recursos gramaticais, fraseológicos e estilísticos reflete, por meio da entonação expressiva empregada, o tom polêmico do sujeito divulgador, mediante o posicionamento adotado a respeito da temática do aborto.

Tal como verificamos na seção anterior, a revista Catolicismo, porta voz da TPF, redigida "por uma equipe altamente capacitada de jornalistas católicos" caracteriza-se como veículo impresso, de periodicidade mensal.

A Folha Universal é um veículo impresso, de periodicidade semanal da Igreja Universal do Reino de Deus (IURD), denominação evangélica que tem mais relações com a mídia. Tem circulação nacional e uma tiragem média de 2,5 milhões de exemplares.

A contemporaneidade do enunciado em ambos os artigos jornalísticos de divulgação religiosa constitui-se por meio da utilização da seguinte temática: o caso ocorrido em Alagoinha e Recife (PE) em fevereiro de 2009 e amplamente noticiado pela mídia.

Os artigos jornalísticos presentes na edição de 14 março da Folha Universal (T17) e da edição de abril da Revista Catolicismo (T14) expõem, portanto, um fato contemporâneo a sua realização. Tal como observamos, nos textos jornalísticos da esfera midiática, a objetividade é produzida por meio de recursos enunciativos que procuram conferir efeito de sentido de imparcialidade jornalística, segundo os quais os assuntos noticiados seriam independentes da instância jornalística que os veicula: a) predominância da terceira pessoa; b) utilização de dados estatísticos: "Algumas pesquisas chegaram a dar 90\% de respostas contrárias ao aborto (VIOTTI, 2009, p. 40)”; c) utilização do discurso citado, com a presença de atores com legitimidade social para abordar o tema em questão: 
Em artigo publicado no jornal "Folha de São Paulo", o oncologista Draúzio Varela, um dos médicos mais respeitados do País, resumiu de forma categórica o papel desempenhado por todos os envolvidos no episódio de Recife. Os médicos, que foram excomungados pelo Clero Romano, cumpriram a lei ao "interromper a prenhez gamelar numa criança franzina" e salvaram a vida dela (FOLHA UNIVERSAL, 2009, p. 14).

Temos a voz do ator social, o oncologista Dráuzio Varella "um dos médicos mais respeitados do país", que, embora não seja pertencente à comunidade religiosa da IURD, apresenta-se como uma autoridade legítima e reconhecida, ao trazer valores partilhados com a comunidade, com a defesa de um ponto de vista contrário à postura da Igreja Católica no caso da menina estuprada em Pernambuco.

Embora o tema contemplado seja pertencente à temática pública institucionalizada, verifica-se que a mídia religiosa escrita possui um público alvo mais limitado, por ter seu meio de difusão realizado, sobretudo, por meio de assinaturas, no caso da revista Catolicismo, ou de difusão interna, no caso da Folha Universal.

Os artigos apresentam um público-alvo homogêneo, mais restrito, da comunidade que supostamente partilha das mesmas crenças e valores propugnados no enunciado.

A reportagem da Folha Universal caracteriza-se como um enunciado verbo-visual com a presença de fotografias do médico Dráuzio Varela, de Sérgio Cabral Júnior (excomungado pelo Clero romano), da vítima e uma caricatura.

$\mathrm{O}$ artigo da revista Catolicismo realiza-se como um enunciado verbal; apenas nas páginas subsequentes da revista é colocada a fotografia de Dom José Cardoso Sobrinho, Arcebispo Metropolitano de Olinda e Recife.

Vejamos como o acento de valor apreciativo é transmitido por meio de uma entonação expressiva, segundo a qual a presença do outro é identificável por determinadas marcas linguísticas. Verificamos, portanto, como se constitui o contraste de ideias entre o posicionamento defendido e o rechaçado pelos enunciados.

Comecemos pela análise dos títulos "Médicos Contra o Vaticano" e "Em Recife, tentativa de quebrar a barreira psicológica contra o aborto" e da temática anunciada no sumário da revista Catolicismo "Recife: Estrondo publicitário a favor do aborto". Mediante eles, já se assume a posição valorativa da esfera ideológica na qual o artigo se insere. $\mathrm{O}$ conteúdo temático dos artigos é assumido pela voz do autor-jornalista, de tal forma que os textos vão sendo amarrados em suas articulações composicionais pela posição valorativa da esfera religiosa em que estão inseridos. 
Como mecanismos argumentativos da palavra interiormente persuasiva, empregada pelo autor-jornalista do enunciado católico (VIOTTI, 2009), também se percebe a crítica à mídia, conforme a qual o ponto de vista por ela defendido contrarie os valores católicos. A oposição ao ponto de vista do outro "esfera midiática" se estabelece na medida em que essa perspectiva, segundo essa esfera, estaria distorcendo a realidade por meio da utilização de argumentos infundados e inverossímeis.

Verificamos no enunciado extraído da revista Catolicismo, a presença do tom polêmico na própria referência ao outro "mídia" como falacioso, que não aspira à verdade, à isenção e à objetividade jornalísticas:

Mas a confusão do noticiário não ficou apenas nisso. Muitos detalhes foram omitidos para favorecer a posição pró-aborto [...]. O quadro criado pelo noticiário de certa mídia era tendencioso. [...] Estava montado um verdadeiro circo de desinformação e sensacionalismo, que obviamente servia a um único propósito: favorecer a prática do aborto e dividir a opinião católica (VIOTTI, 2009, p. 40, grifos nossos).

Como mecanismos argumentativos da palavra interiormente persuasiva empregada pelo autor-jornalista católico constatamos também a presença citação da palavra autoritária na defesa do ponto de vista. Observamos, assim, a citação do Código de Direito Canônico Cânon 1398 - como argumento de autoridade para defesa do ponto de vista da esfera ideológica católica:

A lei da Igreja prevê, em seu cânon 1398: "Quem provoca o aborto, seguindo-se o efeito, incorre em excomunhão latae sententiae", ou seja, quem participa do aborto incorre em pena automática (sem necessidade de ser decretada) de excomunhão (VIOTTI, 2009, p. 40).

O artigo da Folha Universal apenas reproduz o conteúdo do artigo de Dráuzio Varella (relação intertextual) "Incoerência Católica", publicado na Folha de São Paulo, no dia 14 de março de 2009 (T18), com o qual é partidário dos valores expostos (Cf. C, p. 154).

Notamos, por meio da entonação expressiva empregada no enunciado da IURD, o posicionamento favorável adotado pelo enunciado ao artigo de Varella e, por conseguinte, à prática dos médicos excomungados pela Igreja Católica, tal como destacamos em alguns exemplos, a seguir:

A polêmica em torno da menina de 9 anos, estuprada pelo padrasto, ganhou o capítulo mais lúcido, no último dia 14 (FOLHA UNIVERSAL, 2009, p. 14). 
O diretor médico do Centro Integrado de Saúde Amaury de Medeiros, em Pernambuco, Sérgio Fernandes Cabral Junior, um dos excomungados pela Igreja Católica, avaliou como "pertinente" a atitude de Dráuzio Varella. É uma incoerência quando qualquer instituição religiosa tende a bloquear a execução de políticas públicas de saúde (FOLHA UNIVERSAL, 2009, p. 15).

Os valores católicos de defesa da vida veiculados por esse objeto-discurso são propostos pela enunciação divulgadora, no papel actancial de um destinador-manipulador, cujos ideais, postos como objeto de valor a serem partilhados com o enunciatário, são compatíveis à formação discursiva católica. Esse mesmo sujeito da enunciação, no papel também de agente de prestígio vinculado à revista Catolicismo, dentro do campo discursivo católico, tem seu fazer reconhecido: a exposição da matéria de fé e moral deve ser executada e praticada pelos membros participantes e cúmplices da formação discursiva considerada. A formação discursiva, como sistema fundado em figuras e temas de determinado discurso, acaba por esclarecer o lugar do sujeito na polêmica sobre a preservação da vida.

Observamos, novamente, duas formas de habitar o espaço discursivo que, por sua própria constituição semântica, são polêmicas. Ao éthos católico pautado pelo tom instrutivo e construído pelo efeito de sentido de objetividade e imparcialidade, opõe-se o éthos beligerante da IURD. Este, constituído pela isotopia da guerra, procura combater seu inimigo "Igreja Católica" rechaçando o ponto de vista defendido por esse "outro" em seu próprio enunciado. 
CAP. IV

A NOÇÃO DE ÉTHOS:

FUNDAMENTOS TEÓRICOS E BASES PARA A OPERACIONALIZAÇÃO

A retórica é a faculdade de ver teoricamente o que, em cada caso, pode ser capaz de gerar a persuasão. [...] A retórica parece ser capaz de, por assim dizer, no concernente a uma dada questão, descobrir o que é próprio para persuadir. Por isso dizemos que ela não aplica suas regras a um gênero próprio e determinado.

Aristóteles $^{80}$

\footnotetext{
${ }^{80}$ Aristóteles (2005, p. 33).
} 


\section{Semiótica e Retórica: fundamentos teóricos e bases para a operacionalização da noção de éthos}

Zilberberg (2006a) ${ }^{81}$ refere-se ao objetivo principal da retórica, tal como estabelecido por Aristóteles (2005, p. 33): “A retórica é a faculdade de ver teoricamente o que, em cada caso, pode ser capaz de gerar a persuasão". Ressaltamos a epígrafe que abre este Capítulo para dar respaldo à definição de retórica com a qual partilhamos nesta tese: "retórica é a arte de persuadir pelo discurso" (REBOUL, 2004, p. XVI). Entendemos a retórica, portanto, como uma teoria do discurso que tem por objetivo o exame de enunciados persuasivos.

A retórica esteve muitas vezes relegada ao segundo plano, tratada pejorativamente pelo senso comum como sinônimo de coisa empolada, artificial, aravessada pelo descrédito de uma persuasão vinculada ao engodo, a serviço da falsidade.

Cabe a Aristóteles (384-322 a. C.) a reabilitação da retórica, integrando-a a uma visão sistemática do mundo, de modo a transformá-la em um sistema retórico. Abordaremos como se processa essa sistematização a seguir.

Todo sistema tem por princípio uma classificação. Reboul (2004, p. 41) define com vagar a classificação do sistema retórico, tal como desenvolvido por Aristóteles. Na sistematização que a retórica faz de seu objeto, ela procede à separação entre pensamento e linguagem, mediante a sua dissociação em cinco partes, que podem ser associadas às fases de elaboração de um discurso. Lembrando Aristóteles (2005), temos as seguintes partes que caracterizam o sistema retórico: a) inventio (busca de argumentos e de outros meios de persuasão); b) dispositio (ordenação dos argumentos); c) elocutio (estilo, conversão em linguagem do material das fases anteriores); d) actio (proferição efetiva do discurso); e) memória (memorização do discurso).

Como precisar o papel preponderante da retórica na tradição de estudos das teorias da linguagem, dentre as quais destacamos a semiótica?

Entre as propostas que procuraram relacionar semiótica e retórica e das quais nos utilizamos em nossa tese, chamamos a atenção aos trabalhos de Barros $(2002,2008)$ e

\footnotetext{
${ }^{81}$ Agradecemos aos professores Ivã Carlos Lopes e Luiz Tatit que gentilmente nos cederam a versão provisória da tradução dos Elements de grammaire tensive. Ressaltamos, entretanto, que optamos por manter a numeração original das páginas, tal como no original francês.
} 
Zilberberg (2006a). Inicialmente, apresentaremos cada uma dessas propostas, para, em seguida, evidenciar nossa perspectiva, que busca desenvolver e expandir os desenvolvimentos ora expostos, mediante a proposição de uma revitalização da retórica, unindo-a ao ponto de vista tensivo da semiótica. Assim sendo, não podemos deixar de destacar a coletânea de artigos organizada na revista Langages, número 137 (BORDRON; FONTANILLE, 2000), obra pioneira a formalizar teoricamente o tratamento tensivo da retórica.

O interesse da semiótica pela retórica se explicaria, em um primeiro momento, pelo reaparecimento da problemática do discurso ao longo dos estudos semióticos.

Entendemos o percurso gerativo do sentido como simulacro metodológico das abstrações que o leitor faz durante a leitura de um texto e que se define em três níveis homogêneos de análise. Estaremos amparados no conceito de nível discursivo, enquanto instância do percurso gerativo do sentido e, ao mesmo tempo, realização do conteúdo manifestado pelo texto e responsável pelo efeito de individualidade dos conteúdos expressos.

São objeto de estudo da análise discursiva: "as projeções da enunciação no enunciado, os recursos de persuasão utilizados pelo enunciador para manipular o enunciatário, a cobertura figurativa dos conteúdos narrativos abstratos” (BARROS, 2002, p. 73).

Barros (Idem, ibidem) ressalta a associação da semiótica com outras propostas teóricas a fim de examinar as organizações sintáticas e semânticas do discurso. Para a elaboração da sintaxe discursiva, pautada pela problemática da enunciação ${ }^{82}$, a autora destaca a associação com as "diferentes colocações da semântica da enunciação - da argumentação, da pressuposição, dos atos de fala -, na teoria do texto literário, principalmente quando aprecia questões de foco narrativo, na estilística e na retórica" (Idem, ibidem).

A enunciação, de início rejeitada por razões de método da semântica estrutural, foi em seguida reintegrada no corpo teórico da análise do discurso, como pressuposto lógico do enunciado, e definida pelas operações de debreagem e embreagem. Na perspectiva do discurso em ato, a enunciação tem a primazia e seu sujeito define-se, de maneira indissociável, como sujeito sensível da percepção e sujeito discursivo da predicação (BERTRAND, 2003, p. 419).

\footnotetext{
82 "A mediação entre estruturas narrativas e estruturas discursivas é tarefa da enunciação: os esquemas narrativos são assumidos pelo sujeito da enunciação, que os converte em discurso e nele deixa suas 'marcas'. Dessa forma, o exame da sintaxe e da semântica do discurso permite reconstruir e recuperar a instância da enunciação, sempre pressuposta" (BARROS, 2002, p. 72).
} 
À semântica discursiva determinada pela assunção em discurso de configurações temáticas e figurativas, a estudiosa sugere uma aproximação da teoria com as questões de estilística, tal como desenvolvidas pela poética e pela retórica.

Em meados dos anos 60 dá-se o ressurgimento da perspectiva retórica, do qual podemos distinguir dois enfoques diferenciados. O primeiro movimento, ao incluir Jean Cohen, Gérard Genette, Roland Barthes, Jean Dubois, Jean M. Klinkeberg, entre outros, sob a designação de grupo $\mu$, postula que "a literatura é antes de tudo um uso singular da linguagem". De acordo com essa perspectiva, o grupo propõe que "é precisamente a teoria desse uso que constitui o primeiro objeto de uma retórica geral, e, quem sabe, generalizável" (DUBOIS et alii, 1974, p. 23). Os procedimentos característicos do domínio literário parecem reduzidos a uma estilística da expressão, sistematizada pelo estudo das figuras de estilo, consideradas como o desvio de um "grau zero" da linguagem e, portanto, centrada na elocutio.

Entre os procedimentos de persuasão, propostos por Barros (2002), ao longo do exame das teorias pragmáticas as quais teriam influenciado a semiótica, daremos destaque a um segundo movimento, empreendido pelos enfoques da Nova Retórica, obtidos, principalmente, por meio dos trabalhos de Meyer (2007), Perelman e Olbrechts-Tyteca (2005). Vejamos como Perelman (1984, p. 234) procede à definição da teoria da argumentação indicada pela Nova Retórica:

Uma teoria da argumentação, na sua concepção moderna, vem assim retomar e ao mesmo tempo renovar a retórica dos Gregos e dos Romanos, concebida como a arte de bem falar, ou seja, a arte de falar de modo a persuadir e convencer, e retoma a dialética e a tópica, artes do diálogo e da controvérsia.

Merece destaque o Tratado de Argumentação de Perelman e Olbrechts-Tyteca (2005, p. 8), que procura versar sobre os recursos discursivos empregados a fim de se obter a adesão dos espíritos, cuja exposição se pauta apenas na técnica que utiliza a linguagem para persuadir e para convencer.

Ressaltamos a associação com a retórica, nesse primeiro momento, no que tange às "formas de composição do discurso e pela preocupação com os procedimentos de argumentação e persuasão" (Idem, p. 73). Assim, são analisados, pelo modelo semiótico, dois aspectos da sintaxe discursiva sob influência da teoria retórica: as projeções da enunciação no enunciado e as relações argumentativas entre enunciador e enunciatário. Por enunciador e 
enunciatário, compreendemos os "desdobramentos do sujeito da enunciação que cumprem os papéis actanciais de destinador e de destinatário do objeto-discurso" (BARROS, 2002, p. 92). Caberia ao enunciador, portanto, a responsabilidade pelos valores do discurso, de maneira a levar o enunciatário a crer e a fazer. O fazer manipulador realizado pelo enunciador corresponde a um fazer persuasivo. Em contrapartida, temos o fazer interpretativo do enunciatário. No nível discursivo, consoante Barros (2002, p. 93), o contrato fiduciário realiza-se enquanto um contrato de veridicção, o que determina o estatuto veridictório de um discurso determinado. Aponta, ainda, a autora que "o fazer persuasivo do enunciador é diferente segundo o jogo de imagens que constrói de si mesmo e do enunciatário - o que o leva à sedução, à tentação, à provocação ou à intimidação" (Idem, p. 95). Um fazer pragmático e um fazer cognitivo estão em jogo.

Competiria à sintaxe do nível discursivo a análise dos procedimentos argumentativos entre enunciador e enunciatário e, à semântica discursiva, responsável pelos procedimentos de concretização do sentido, que são a tematização e figurativização, a recuperação dos conteúdos ideológicos veiculados pelo discurso.

Com base nessas afirmações, poderíamos relegar o nível discursivo como sendo o lugar por excelência da retórica? O próprio Dicionário de Semiótica estabelece essa afirmação com reserva, vejamos:

O interesse atual pela retórica explica-se pelo reaparecimento, sob o impulso da semiótica, da problemática do discurso. Se bem que não possam, por razões evidentes, ser integrados tais quais na semiótica discursiva, certos campos teóricos da antiga retórica correspondem às preocupações atuais e merecem ser explorados (GREIMAS; COURTÉS, 2008, p. 421).

Além disso, de acordo com Barros (2008, p. 27), os diálogos que a semiótica vem travando no âmbito da ciência retórica têm sido muito produtivos, "seja no tratamento das questões discursivas de persuasão e argumentação, com os contratos fiduciários, a interação entre sujeitos e a construção da identidade e do éthos do enunciador, seja no exame das figuras de conteúdo e expressão".

Como dissemos, apoiados nos desenvolvimentos de Discini (2004b, p. 17), procuramos desenvolver uma proposta de conceituação da noção de estilo, que junte as partes componentes do sistema retórico (inventio, dispositio, elocutio, actio e memória), reexaminando-as sob o prisma da semiótica tensiva. 
Ressalta Reboul (2004, p. 44) que "antes de empreender um discurso, é preciso perguntar-se sobre o que ele deve versar, portanto sobre o tipo de discurso, o gênero que convém ao assunto". Para a inventio, teremos, então, a associação da escolha da problemática relativa à escolha do gênero do discurso, bem como da busca de argumentos e outros meios de persuasão necessários para a construção do discurso. É importante que se faça uma ressalva quanto à noção de gênero empregada nesta tese, e que se insere em um âmbito distinto daquele proposto pela retórica. A retórica remete a três gêneros oratórios: o deliberativo, o demonstrativo e o judiciário ${ }^{83}$. Situamos esta tese dentro da problemática dos gêneros tal como proposta por Bakhtin (2003). Conforme salienta o autor, ao longo do estabelecimento da definição da problemática dos gêneros do discurso, todos os campos da atividade humana, nas suas mais diversas manifestações, ligam-se ao uso da linguagem, naquilo que ela apresenta de experiência concreta. Por conseguinte, o emprego da língua se efetua por meio de enunciados que refletem as condições específicas de cada campo da atividade humana. Cada um dos campos de utilização elabora tipos relativamente estáveis de enunciados, denominados "gêneros discursivos", definidos por uma estrutura composicional, uma temática e um estilo. A temática é característica da esfera de sentido e diz respeito ao assunto de que trata o gênero. A estrutura composicional é representada por intermédio da estrutura apresentada pelo texto. O estilo, segundo Bakhtin (2003), refere-se às marcas linguísticas exigidas por um determinado gênero e que o distinguem e, mais do que isso, de acordo com Discini (2004b), o estilo se refere ao éthos do gênero: o estilo do gênero.

Por dispositio é entendida a "maneira de dispor as diferentes partes do discurso, o qual deve ter os seguintes componentes: exórdio, proposição, partição, narração/descrição, argumentação (confirmação/refutação) e peroração" (MOSCA, 2004, p. 28). Trata-se, portanto, da organização interna do discurso. A elocutio "é o estilo ou as escolhas que podem

\footnotetext{
83 "São três os gêneros da Retórica, do mesmo modo que são três as categorias de ouvintes dos discursos. Com efeito, um discurso comporta três elementos: a pessoa que fala, o assunto de que se fala e a pessoa a quem se fala; e o fim do discurso refere-se a esta última, que chama o ouvinte. [...] Donde, resultam necessariamente três gêneros e discursos oratórios: o gênero deliberativo, o gênero judiciário e o gênero demonstrativo (ou epidíctivo). Numa deliberação, aconselha-se ou desaconselha-se, quer se delibere sobre uma questão de interesse particular, que se fale perante o povo acerca de questões de interesse público. Uma ação judiciária comporta a acusação e a defesa: necessariamente os que pleiteiam fazem uma destas duas coisas. O gênero demonstrativo comporta duas partes: o elogio e a censura. Cada um destes gêneros tem por objeto uma parte do tempo que lhe é próprio: para o gênero deliberativo é o futuro, pois que delibera-se sobre o futuro, para aconselhar ou desaconselhar; para o gênero judiciário é o passado, visto que a acusação ou a defesa incide sempre sobre fatos pretéritos; para o gênero demonstrativo, o essencial é o presente, porque para louvar ou para censurar apoiamonos sempre no estado presente das coisas; contudo sucede que frequentemente utilizamos a lembrança do passado ou presumimos o futuro" (ARISTÓTELES, 2005, p. 39).
} 
ser feitas no plano de expressão para que haja adequação forma/conteúdo" (Idem, p. 28-29). À actio associamos a proferição do discurso. Por fim, a memória é concebida como a forma pela qual os discursos seriam conservados por uma determinada comunidade discursiva.

Retomemos o componente discursivo de actorialização, como procedimento argumentativo. Lembremos a análise do enunciado do folheto de missa, suporte do rito eucarístico, visto como feixe de análise, realizada no segundo Capítulo desta tese. Procuramos demonstrar como esse enunciado traz uma retórica própria do gênero. Destacamos a presença, no enunciado do folheto, de um contrato de delegação de vozes que daria ao sacerdote o monopólio da manipulação dos bens de salvação. Caracterizamos, diante disso, a actorialização característica do enunciado do folheto consoante a delimitação entre o que seria pronunciado apenas pelo portador autorizado, no caso, o padre, e as partes da missa a ser pronunciadas pelos fiéis. Temos, assim, um contrato de delegação de vozes, ao longo do qual o narrador, mediante uma debreagem enunciativa de segundo grau, delega voz aos actantes do enunciado (interlocutor e interlocutário), instaurando o diálogo.

Ressaltamos a correlação que procuramos empreender ao longo da análise dos enunciados de divulgação religiosa (Capítulo III), ao projetarmos o espaço tensivo (FONTANILLE e ZILBERBERG, 2001), mediante a correlação dos eixos da intensidade (eixo dos valores de absoluto, onde domina o foco) e da extensidade (eixo dos valores de universo, onde domina a apreensão), relacionando-os, conforme Zilberberg (2007, p. 15), aos estilos enunciativos de retenção e de divulgação. Assim, para o estilo retensivo, temos a pertinência da intensidade; para estilo da divulgação, a pertinência da extensidade.

Na concepção de Aristóteles, a retórica não se definiria, portanto, somente no poder de persuadir, mas na arte de encontrar os meios de persuasão propícios a cada caso.

O filósofo procura, ainda, associar a dialética e a retórica, situando-as no mesmo patamar, na medida em que, tal como ressalta Reboul (2004, p. 35), a retórica utilizaria a dialética como um meio, entre outros, de persuadir ${ }^{84}$. Embora Aristóteles tenha se valido das

\footnotetext{
${ }^{84}$ Esclareçamos a noção de dialética: "Esse termo, que deriva do diálogo, não foi empregado, na história da filosofia, com significado unívoco, que possa ser determinado e esclarecido uma vez por todas; recebeu significados diferentes, com diversas inter-relações, não sendo redutíveis uns aos outros ou a um significado comum. Todavia, é possível distinguir quatro significados fundamentais: $1^{\circ}$. D. como método de divisão; $2^{\circ}$. D. como lógica do provável; $3^{\circ}$. D. como lógica; $4^{\circ}$. D. com síntese dos opostos. Esses quatro conceitos têm origem nas quatro doutrinas que mais influenciaram a história desse termo, mais precisamente a doutrina platônica, a aristotélica, a estóica e a hegeliana" (ABBAGNANO, 2007, p. 315).
} 
bases da dialética, o autor, longe de limitar-se a essa aplicação, introduz na retórica três tipos de provas empregadas como meios de persuadir. Vejamos:

\begin{abstract}
Entre as provas fornecidas pelo discurso, distinguem-se três espécies: umas residem no caráter moral do orador; outras, nas disposições que se criaram no ouvinte; outras no próprio discurso, pelo que ele demonstra ou parece demonstrar. Obtém-se a persuasão por efeito do caráter moral, quando o discurso procede de maneira que deixa a impressão de o orador ser digno de confiança. [...] Obtém-se a persuasão nos ouvintes, quando o discurso os leva a sentir uma paixão, porque os juízos que proferimos variam, consoante experimentamos aflição ou alegria, amizade ou ódio. [...] Enfim, é pelo discurso que persuadimos, sempre que demonstramos a verdade ou o que parece ser a verdade, de acordo com o que, sobre cada assunto, é suscetível de persuadir (ARISTÓTELES, 2005, p. 33-34).
\end{abstract}

A essas provas se associam o éthos (caráter do orador), o logos (discurso) e o páthos (disposição dos ouvintes), o que detalharemos a seguir com mais vagar, tendo por base a importância fundamental dessas noções para a problemática teórica proposta nesta tese.

Para Aristóteles, o éthos constitui a prova mais importante entre as demais, produzidas pelo discurso. Sob a perspectiva do resgate da retórica clássica, observamos, então, o estilo enquanto éthos, conforme recuperado do pensamento de Discini (2004b). Nesse intento, temos respaldo nos desenvolvimentos da noção de éthos elaborada por Maingueneau (2005b), na medida em que o autor ultrapassa e expande o conceito retórico tradicional de éthos ao incorporar o conceito de adesão.

Vejamos como se institui a noção de éthos desenvolvida por Maingueneau (2005b) no quadro teórico da Análise do Discurso francesa.

Ao mesmo tempo que deve demonstrar um modo de dizer, "um modo de enunciação", o enunciador "deve se conferir, e conferir a seu destinatário, certo status para legitimar seu dizer: ele se outorga no discurso uma posição institucional e marca sua relação com um saber" (AMOSSY, 2005, p. 16). O estatuto dessa noção no quadro da Análise do Discurso estaria ligado, desse modo, à enunciação e não a um saber extradiscursivo sobre o enunciador. O próprio pertencimento a um gênero de discurso ou a um certo posicionamento ideológico já induz a expectativas em matéria de éthos. Por éthos entendemos o tom, a voz, o caráter e a corporalidade depreensíveis de uma determinada totalidade de discursos, conforme proposto por Discini (2004b). Juntamente com Maingueneau (2005b, p. 72) concebemos tom como a vocalidade específica que todo texto possui, relacionado a uma fonte enunciativa, que indica quem o disse. Associamos a vocalidade ao corpo do enunciador, à sua dimensão vocal, dada 
mediante determinações físicas e psíquicas. Por caráter temos um "feixe de traços psicológicos" (Idem, p. 72). Para a corporalidade remetemos a "compleição corporal", a "forma de vestir-se e de mover-se no espaço social" (Idem, ibidem).

Ressaltamos o conceito de incorporação como a "maneira pela qual o co-enunciador se relaciona ao éthos de um discurso" (Idem, p. 73). Essa incorporação se caracterizaria pela constituição de um corpo, de uma imagem igualitária daqueles que aderem a um mesmo discurso, por intermédio da identidade de um posicionamento discursivo (Idem, ibidem).

O enunciador não é um ponto de origem estável que se "expressaria" dessa ou daquela maneira, mas é levado em conta em um quadro profundamente interativo, em uma instituição discursiva inscrita em uma certa configuração cultural e que implica papéis, lugares e momentos da enunciação legítimos, um suporte material e um modo de circulação para o enunciado (Idem, p. $75)$.

Temos, assim, a expansão do conceito retórico tradicional de éthos. Para além do conceito de persuasão, "ele é parte constitutiva da cena da enunciação, com o mesmo estatuto que o vocabulário ou os modos de difusão que o enunciado implica por seus modos de existência" (Idem, ibidem).

A noção de éthos associada à determinada totalidade e à noção de estilo, tal como desenvolvida por Discini (2004b), nos dá a fundamentação necessária para a articulação da noção de estilo e de éthos à semiótica tensiva.

Estilo é visto como um conjunto de traços particulares, recorrentes do plano do conteúdo ou da expressão, que produzem um efeito de sentido de identidade, por meio dos quais se determina a singularidade e especificidade de um autor, de uma época etc. Esses traços configuram um éthos discursivo, uma imagem do enunciador. Mas, o que seriam esses traços recorrentes? Podemos exemplificá-los como sendo determinadas características, seja do plano de conteúdo, por exemplo, a reiteração de certos temas; seja do plano da expressão, por exemplo, as formas de organização de um determinado texto (FIORIN, 2008).

O éthos não é dito, ele se mostra por meio das marcas da enunciação depreensíveis do enunciado e pelo modo particular de combinação de temas e figuras. Por intermédio desses mecanismos, vemos emergir o juízo de valor e, por conseguinte, o ponto de vista do observador (ator debreado), o qual remete, por sua vez, ao enunciador. 
Tal como demonstramos na introdução desta tese, procuramos ampliar o diálogo proposto por Zilberberg (2006a) entre o ponto de vista tensivo da semiótica e a retórica.

Procuramos, mediante a observação feita desse diálogo, fornecer os alicerces para a operacionalização da noção de éthos, contemplada nos discursos de fundação, de fidelização e de divulgação religiosa.

Reservamos, para esse Capítulo o espaço necessário para os tópicos que pretendemos elencar, seja como base para a operacionalização da noção de éthos, seja como base para a depreensão das particularidades dos modos de construção da tipologia dos discursos de divulgação religiosa, ou ainda na distinção entre o discurso religioso, o discurso fundador, o discurso de fidelização e o discurso de divulgação.

Perelman e Olbrechts-Tyteca (2005) demonstram os meios discursivos de se obter a adesão, mediante o emprego de técnicas argumentativas utilizadas para persuadir ou convencer o auditório (enunciatário, para a semiótica). Destaca-se, assim, o desenvolvimento de uma teoria da argumentação dirigida "a indivíduos em relação aos quais ela se esforça para obter a adesão" (PERELMAN, 1984, p. 234).

No quadro da semiótica, tomamos como base a proposta de Fontanille (2008), segundo a qual a argumentação estaria situada no tempo de uma prática discursiva. Fontanille (Idem, p. 42) afirma que cada discurso argumentativo "visa a uma fase que lhe é posterior: a crença, a adesão, a decisão e a ação". É exatamente essa estrutura dada por intermédio dessa sequência de fases, que organiza o tempo dos enunciados em análise. As flutuações temporais que, na cena prática, constituem as manipulações cognitivas e passionais do enunciatário, são, pois, a verdadeira "substância estratégica", que, por meio da ordem dos argumentos no enunciado, age sobre a adesão constituinte das cenas práticas dos discursos de fundação, de fidelização e de divulgação religiosa.

Zilberberg (2006a) destaca dois campos de ação do discurso persuasivo: a) a argumentologia, implicativa e de atonia reduzida; b) a tropologia, concessiva e de maior tonicidade.

Nossa proposta pretendeu pensar a argumentação enquanto busca de adesão consoante a um determinado posicionamento discursivo, no que diz respeito a esse auditório constituinte dos gêneros de divulgação. 
Retomemos, dentro da tipologia proposta (Capítulo III), a divulgação propagandista, mediante a análise da unidade "A adoração que Deus aprova" $\left(\mathbf{T 1 2}{ }^{\mathbf{8 5}}\right)$, extraído do livro $O$ que a Bíblia realmente ensina, e pertencente à formação discursiva das Testemunhas de Jeová. Analisamos nessa unidade como o enunciatário, tendo realizado a adesão ao sistema de valores proposto, deveria efetuar a passagem do saber considerado "falso" ao saber "verdadeiro". Observamos como os recursos argumentativos empregados pelo enunciador, a fim de que o enunciatário adquirisse a competência da adequada identificação da "adoração verdadeira", situam a sua argumentação no tempo de uma prática discursiva de conversão.

Para que possamos retomar os tipos de argumentos apresentados, retomemos os dois aspectos segundo os quais as técnicas argumentativas se mostraram:

O fato de o objetivo da argumentação ser o de intensificar a adesão do auditório a certas teses apresentadas pelo orador traz como consequência que as técnicas argumentativas se venham a apresentar sob dois aspectos diferentes. O aspecto positivo consistirá no estabelecimento de uma solidariedade entre teses que se procuram promover e as teses já admitidas pelo auditório: trata-se de argumentos de ligação. O aspecto negativo visará abalar ou romper a solidariedade constatada ou presumida entre as teses admitidas e as que se opõem às teses do orador: tratar-se-á da ruptura das ligações e dos argumentos de dissociação (PERELMAN, 1984, p. 246).

Ainda conforme Perelman (Idem, ibidem), os argumentos de ligação podem ser agrupados em três classes: "os argumentos quase lógicos, os argumentos fundados na estrutura do real, e aqueles que permitem estruturar a realidade". Por argumentos quase lógicos, o autor entende aqueles que, pela sua estrutura, podem ser aproximados aos raciocínios formais, lógicos e matemáticos, diferenciando-se destes últimos apenas por um esforço de redução ou de precisão, o que caracterizaria uma aparência demonstrativa (PERELMAN; TYTECA, 2005, p.219). No que concerne aos argumentos fundados sobre a estrutura do real, são analisadas as ligações que fundamentam o real pelo recurso ao particular (Idem, p.399). Dentre estes, destacamos, ao longo das análises empreendidas, a utilização da argumentação pelo exemplo e pela ilustração.

Perelman e Olbrechts-Tyteca (2005, p. 413), a respeito do fundamento pelo caso particular, ressaltam a argumentação pelo exemplo como estratégia argumentativa. Para

\footnotetext{
${ }^{85}$ T12 refere-se à indicação do texto, tal como ele consta no exemplar "Anexos" e que constitui o segundo volume desta tese, como temos dito.
} 
elucidar, retomemos a análise proposta da narrativa de Atos dos Apóstolos (At, 1-3), realizada no primeiro Capítulo desta tese. Nessa narrativa, a vida da primeira comunidade de fé, um caso particular, é estabelecida como um exemplo, um modelo de conduta a ser imitada (PERELMAN; OLBRECHTS-TYTECA, 2005, p. 414). Notamos o quanto o comportamento dos membros da comunidade era exemplar por constituir um simulacro intersubjetivo da perseverança no cumprimento de desígnios divinos.

Já no Capítulo terceiro, no decorrer da análise da Carta Encíclica "Deus Caritas Est", destacamos Madre Teresa de Calcutá, um caso particular, ao ser estabelecido como um exemplo, um modelo de conduta exemplar a serviço da caridade a ser imitada.

O prestígio de uma pessoa é uma qualidade que incita a imitar os seus comportamentos e a seguir os seus juízos. É ele que, qualquer que seja o seu fundamento, está na base do argumento de autoridade, tão essencial em todos os domínios em que não se dispõe de um procedimento admitido para o estabelecimento dos fatos e das verdades. Este argumento foi frequentemente atacado, enquanto se contestava muitas vezes não o uso do argumento, mas a autoridade daqueles aos quais se fazia apelo (PERELMAN, 1984, p. 256).

Ressaltemos o uso argumentativo das figuras, tal como discorremos ao longo da tese.

$\mathrm{O}$ uso argumentativo das figuras, encaradas habitualmente como figuras de estilo, permite-nos sublinhar uma distinção importante. Uma figura é argumentativa se o seu emprego, ao arrastar uma mudança de perspectiva, parece normal relativamente à nova situação. Pelo contrário, se o discurso não arrasta a adesão do auditor, a figura será percebida como ornamento, como figura de estilo, tendo talvez algum valor literário, mas sendo ineficaz como meio de persuasão (PERELMAN, 1984, p. 243).

Dentre as figuras retóricas que têm por objetivo aumentar o efeito de sentido de presença, citemos a utilização da acumulação como figura de repetição, tal como examinamos a série de atributos e qualificações atribuídas a Nossa Senhora, obtidas ao longo da análise referente à ladainha de Nossa Senhora, empreendida no segundo Capítulo desta tese.

Afinal, como destaca Fontanille (2007, p. 217), a tomada de posição supõe "um corpo próprio, ela instaura um campo de presença, com uma profundidade que pode ser avaliada". Emerge, pois, do enunciado, um corpo sensível, modulado pelos efeitos passionais determinados pelas estratégias argumentativas e que deve se instituir na tomada de posição e adesão a um determinado discurso. 
Para Maingueneau (2005, p. 69) "além da persuasão por argumentos, a noção de éthos permite, de fato, refletir sobre o processo mais geral da adesão dos sujeitos a uma certa posição discursiva”.

Diante disso, procuramos observar não só a persuasão por argumentos, mas também como se processa na totalidade de divulgação, na fidelização e na fundação, a constituição de um corpo enquanto imagem igualitária daqueles que aderem a um mesmo posicionamento discursivo.

Dessa forma, ao nos situar nos desenvolvimentos recentes da teoria, não podemos conceber a enunciação sem a participação de um corpo onipresente (TATIT, 1997). Em relação a esse sujeito que deixa transparecer partes de seu corpo na percepção de um mundo discursivizado, propomos associar, com apoio em Discini (2004 a, 2005c, 2010), a noção de aspectualização do ator de enunciação à noção de estilo (éthos) proposta pela autora, como caráter, tom, voz e corporalidade, característicos de um modo de dizer e de habitar o espaço social, depreensível de uma totalidade de textos.

Nesse sentido, a noção de aspecto, ligada à categoria temporal e definida como um ponto de vista sobre a ação, será correlacionada aos processos discursivos de antropomorfização do sujeito enunciador.

Retomemos a proposição de Discini (2004a), ao destacar a ausência de estudos no âmbito semiótico, determinada pelo aprofundamento da noção de estilo, dada mediante a construção do sujeito visto sob a intensidade do sentir. Vejamos:

Permanecemos sabendo muito pouco, quase nada, do corpo como fenômeno, do corpo como unidade promovida no fazer perceptivo em relação aos próprios fenômenos; do corpo como resposta ao elemento fórico, visto como elemento tensivo que, ao privilegiar paradas no seu fazer, pressupõe continuidades. Falta verdadeiramente a síntese perceptiva do sujeito, dada por uma intersecção tempo-espaço em profundidade figural, como propõe Zilberberg em Raison et poétique du sens ${ }^{86}$ (DISCINI, 2004a, p. 2).

Procuramos associar as noções de éthos ao conceito de presença, da semiótica tensiva, e, desse modo, determinar a noção do observador que, ao imprimir um ritmo aos seus discursos, contribui para a fundamentação do éthos.

A noção de presença, dentro da perspectiva semiótica, é definida da seguinte forma:

\footnotetext{
${ }^{86}$ Zilberberg (2006).
} 
Na perspectiva semiótica, a presença (o "estar aí") será considerado como uma determinação atribuída a uma grandeza, que a transforma em objeto de saber do sujeito cognitivo. Tal acepção, essencialmente operatória, estabelecida no quadro teórico da relação transitiva entre o sujeito do conhecimento e o objeto cognoscível, é muito ampla: estão presentes neste caso, todos os objetos de saber possíveis e a presença identificam-se, em parte, com a noção de existência semiótica (GREIMAS; COURTÉS, 2008, p. 382-383).

A noção de ritmo nos permite depreender o modo de presença dos enunciados da totalidade religiosa católica, bem como sedimentar nossa proposta de tipologização do discurso de divulgação religiosa.

Delineamos, portanto, o conceito de éthos, o ator da enunciação, em consonância com a totalidade recortada para análise, na depreensão de uma percepção de mundo mais acelerada ou menos, que o sujeito tem do mundo discursivizado. Propomos, diante do exposto, traçar, de forma mais abrangente, o modo de presença dos enunciados enfeixados pelo discurso de divulgação religiosa e, por conseguinte, o modo próprio de presença da totalidade recortada e, até mesmo, do discurso religioso em si.

Assim, tal como sugere Zilberberg (2006b), estaremos aliados aos desenvolvimentos recentes da semiótica ao exercer a escuta do figural, ou seja, recuperar algo profundo a partir da superfície figurativa do discurso.

Estaremos diante de uma pessoa, tempo e espaço, determinados conforme um "fundo figural” (ZILBERBERG, 1986, p. 92); este, pressuposto ao nível figurativo, orienta-se segundo a tensividade, sendo determinado pela correlação entre os eixos do espaço tensivo, a intensidade do sensível e a extensidade do inteligível.

Apoiamo-nos na definição de Discini (2010, p. 7), segundo a qual "o figural, como pressuposto, sustenta seu pressuponente, a concretude figurativa do discurso, contribuindo para que se vislumbre a presença como 'campo de presença', ou uma presença que vai de x a y".

Amparados na fenomenologia de Merleau-Ponty (1994), a noção de corpo será concebida como um modo de presença da qual se depreendem todas as relações da vida perceptiva e do mundo sensível.

Associamos o ser que percebe e sente de Merleau-Ponty (Idem) com o sujeito enunciativo, que, ao instalar um centro dêitico, exerce a escolha de valores temporais e 
aspectuais desde as etapas mais profundas do modelo, o que remetemos, por fim, à noção de éthos proposta por Discini (2004b), entendido como tom, voz, caráter e corporalidade.

A noção de ritmo será relacionada à noção do observador correlacionado, por Discini (2005d, 2010), aos processos discursivos de antropomorfização do sujeito enunciador. Concebemos um sujeito que, ao imprimir um ritmo aos seus discursos, contribui para a fundamentação do éthos, o ritmo dos textos determinado por meio da percepção de um corpo que percebe e sente.

Remetemos, dessa maneira, ao domínio do andamento, subjacente ao ritmo, com a percepção mais acelerada, ou menos, de um modo de presença na percepção de um mundo discursivizado, a que se relacionam a tonicidade ou atonia das percepções.

Propusemos dar justificativa a este projeto com respaldo na afirmação proposta pelos desenvolvimentos da semiótica tensiva, de que o sujeito semiótico, antes de assumir valores socioculturais e ideológicos, em conformidade com a formação discursiva em que se encontra instaurado, estaria operacionalizando a seleção de valores tensivos desde as etapas mais profundas do modelo.

Longe de qualquer remissão ao psicologismo, ou de qualquer tendência ontológica que poderia estar fora das preocupações semióticas, concebemos uma espécie de protótipo do sujeito da enunciação realizado em uma prefiguração profunda de percepções e sentimentos, e concebido como "tensividade fórica".

Entendemos, por tensividade fórica (GREIMAS; FONTANILLE, 1993), a categoria concernente ao nível de pré-condições da significação enquanto um patamar de "présentimento", segundo o qual se encontrariam o sujeito para o mundo e o mundo para o sujeito. A caracterização de uma instância de "tensividade fórica" será configurada, tal como postula Tatit (1997, p. 17), como recurso ao nível missivo "onde os valores remissivos e emissivos articulam-se sintática e ritmicamente gerando as matrizes das descontinuidades e das continuidades que estruturam os discursos verbais e não-verbais".

Ao relacionar a função (fazer missivo) com seus dois funtivos (fazer remissivo e emissivo), podemos, de acordo com Zilberberg (2006b), obter a seguinte correlação: ao fazer remissivo, temos como correspondente a parada, ou seja, o antiprograma; ao fazer emissivo (continuativo), associamos a parada da parada.

Dessa forma, a partir de determinadas predominâncias tensivas ou missivas, foi possível entrever um sujeito operando a escolha de valores de continuidade (euforia) ou de 
descontinuidade (disforia), antes mesmo da operacionalização de configurações modais, actanciais ou temático-figurativas (TATIT, 1997, p. 26). A escolha de valores pertencentes à dimensão da extensidade contribui para os efeitos de sentido de desaceleração e de restituição da duração, quer seja da relação entre o sujeito e o objeto, quer seja entre os próprios sujeitos. De maneira inversa, a escolha de valores intensos revela a tendência do texto para a aceleração e a concentração. Com base nesses pressupostos e nas definições de Tatit (1997), podemos entender que o andamento (aceleração/desaceleração), observado tanto no plano do conteúdo, quanto no plano de expressão dos enunciados recortados para análise, determina o tempo (duração).

A experiência do espaço é regida pela experiência do tempo, sendo este, pela velocidade. Assim, o andamento se coloca como medida de velocidade, o que se refere à presença de velocidades maiores ou menores na percepção que o sujeito tem do mundo feito discurso.

Esta é uma maneira de compreender as relações juntivas, pelo fato de que uma relação de conjunção ou de disjunção somente é experienciada por um actante sujeito, caso a conjuntividade estabeleça alguma duração. A experiência do sujeito vai se alongando à medida que o andamento decresce. Teremos, pois, experiências conjuntivas conduzidas pela extensão e duração do percurso; ou experiências construídas por mediação do instante, pautadas pela transição imediata, sem duração que apresente uma continuidade possível, e que possa remeter à práxis semiótica apreendida em suas duas dimensões: a intensidade (sensível) e a extensidade (inteligível).

Destacamos dos capítulos iniciais da obra Élements de Grammaire Tensive (ZILBERBERG, 2006b) as particularidades que definem o denominado "ponto de vista tensivo", que é, segundo o autor, herança incerta da retórica. A seguir, nos deteremos na exposição dos conceitos principais realizados pelo autor ao longo da obra (Cf. MENDES; SILVA, 2009).

Um dos conceitos de que Zilberberg trata é o de direção, que pode ser descendente, quando a estesia caminha para a anestesia, e ascendente, quando ocorre o contrário. Dessa direção, decorrem os estilos tensivos - ascendente, da resolução ao assomo, ou seja, do inteligível para o sensível, e descendente, do assomo à resolução.

A depreensão de unidades é apresentada como um problema sempre renovado em semiótica, tendo origem nos estudos saussurianos. Nesse raciocínio, o autor admite o "mais" o 
e o "menos" como unidades extremas da progressividade e da degressividade. Caracterizamse, dessa forma, os estilos ascendentes segundo a orientação do menos para o mais e os estilos descendentes, do mais para o menos. O estudioso procura demonstrar de que maneira, a partir de uma direção identificada, unidades acabam por se projetar.

É nessa direção que buscamos associar a noção de estilo desenvolvida por Discini (2004b) ao ponto de vista tensivo proposto por Zilberberg. Nessa formulação, ascendência vs. descendência são vistas como direções $\left[\mathrm{N}_{1}\right]$, atenuação/minimização vs. restabelecimento/ recrudescimento constituem categorias $\left[\mathrm{N}_{2}\right]$ e as derivadas da ordem subsequente $\left[\mathrm{N}_{3}\right]$ configuram unidades, tal como observado no quadro a seguir:

\begin{tabular}{|c|c|c|}
\hline $\mathrm{N}_{1}$ & $\begin{array}{c}\text { continuum orientado } \rightarrow \\
\downarrow\end{array}$ & direção \\
\hline $\mathrm{N}_{2}$ & $\begin{array}{c}\text { categorização } \rightarrow \\
\text { [primeira partição] } \\
\downarrow\end{array}$ & categorias \\
\hline $\mathrm{N}_{3}$ & $\begin{array}{c}\text { segmentação } \rightarrow \\
\text { [segunda partição] }\end{array}$ & unidades \\
\hline
\end{tabular}

Figura 20.Depreensão de unidades a partir de uma direção identificada (ZILBERBERG, 2006a, p. 48)

Ainda no que diz respeito às singularidades do modelo tensivo, merece destaque a introdução dos conceitos de implicação e concessão, o primeiro referente à gramaticalidade das regras e o segundo aos enunciados de ruptura consensuais, que remetem ao acontecimento caracterizado pela realização de um contraprograma, desastroso ou salvador, para o sujeito, conforme o caso (ZILBERBERG, 2006a, p.204).

Se nossa proposta se refere à concatenação entre o nível profundo e as instâncias enunciativas, temos aqui um terreno sólido de desenvolvimento. Para isso, tomamos a noção de direção tensiva, concernente aos dois estilos tensivos sugeridos pelo autor: implicação e concessão. Preservamos, tal como propõe Zilberberg (2006a), a conexão da sintaxe tensiva, que opera por aumentos e diminuições, com a retórica. Como podemos estabelecer uma 
aproximação entre a semiótica tensiva com relação à retórica? É isso que tentamos elucidar por meio desse estudo.

Aumentos e diminuições são definidos também por Meyer (2007, p.51), mas como instrumentos retóricos essenciais: "o mais e o menos são, portanto, instrumentos retóricos essenciais. $\mathrm{O}$ recurso à quantidade desempenha um papel fundamental, pois permite acentuar as diferenças e minimizar as demais". Atentemos para a semiótica.

O apelo à recursividade é motivado por duas razões distintas: (i) para que o recrudescimento e a minimização sejam vividos, não seria sensato que cada operação, na ordem que lhe é própria, tivesse direito de se repetir? (ii) a recursividade também é solicitada para dar conta de sintagmas em princípio impossíveis, como três vezes nada, menos que nada, em que o primeiro opera por recrudescimento recursivo da niilidade e o segundo, por minimização recursiva e ultrapassagem da niilidade, disposição que lembra imediatamente a eficiência imputada à homeopatia. Na mesma linha, o "minúsculo" fica à mercê da irrupção do ínfimo, ou seja, da minimização recursiva que se aplica ao quantum da grandeza subsistente no "minúsculo". As qualidades são ora fases, ora acontecimentos do devir tensivo. (ZILBERBERG, 2006a, p. 171).

Para Zilberberg (Idem), o linguista Roman Jakobson (1969), teria ido longe na identificação entre a retórica e a semiótica de acordo com o que ele considera um ponto de vista contestável, pois, segundo a concepção de Jakobson, o eixo paradigmático seria o eixo das similaridades e o eixo sintagmático, o das contiguidades. Assim, a metáfora seria a figura por excelência da similaridade e a metonímia, a figura da contiguidade. Diante disso, onde se encaixariam as outras figuras, pergunta Zilberberg?

Para tentar responder, tomemos de início a seguinte definição de Meyer:

O objetivo das figuras é instaurar uma identidade que salienta um traço comum - para chamar a atenção sobre o que conta, no espírito de quem o utiliza. Uma evidência, uma presença - especificava Perelman, mas, de qualquer forma, uma substitubilidade que diz o que está em causa, o que é sujeito da discussão, mesmo que a título de resposta (MEYER, 2007, p. 88).

O enunciador pode realizar a combinação, de temas e figuras, de formas diferenciadas com o propósito de chamar a atenção de seu enunciatário para um determinado aspecto da realidade que busque descrever ou explicar.

Um texto dominantemente conotativo não apenas diz o mundo, mas recria-o por meio da linguagem, sendo predominante, portanto, não só o que o texto diz, mas a maneira de dizer 
o que diz. Dessa forma, a discursivização passa a ser significativa na produção do sentido, com realce para o modo particular de combinação de temas e figuras, nos quais se destaca a utilização de recursos diferenciados.

A relevância do plano de expressão no estabelecimento de novas relações de sentido em sua organização e os modos específicos de combinação de figuras e temas para a construção de um determinado efeito de sentido, como já dissemos anteriormente, propiciaram-nos a caracterização do estilo dos textos, ao que fizemos corresponder as noções de estilo ascendente e descendente propostas pela semiótica tensiva. Dessa forma, nosso estudo procurou identificar alguns desses elementos e ressaltar a importância do estudo da discursivização para a construção do estilo do enunciador.

Retomamos a concepção de Zilberberg (2006a, p. 204-205), segundo a qual "os sintagmas implicativos reportam-se à gramaticalidade das regras; os sintagmas concessivos, ao acontecimento, ou seja, ao sucesso de um contraprograma, conforme o caso, desastroso ou salvador para o sujeito.” Observemos o gráfico:

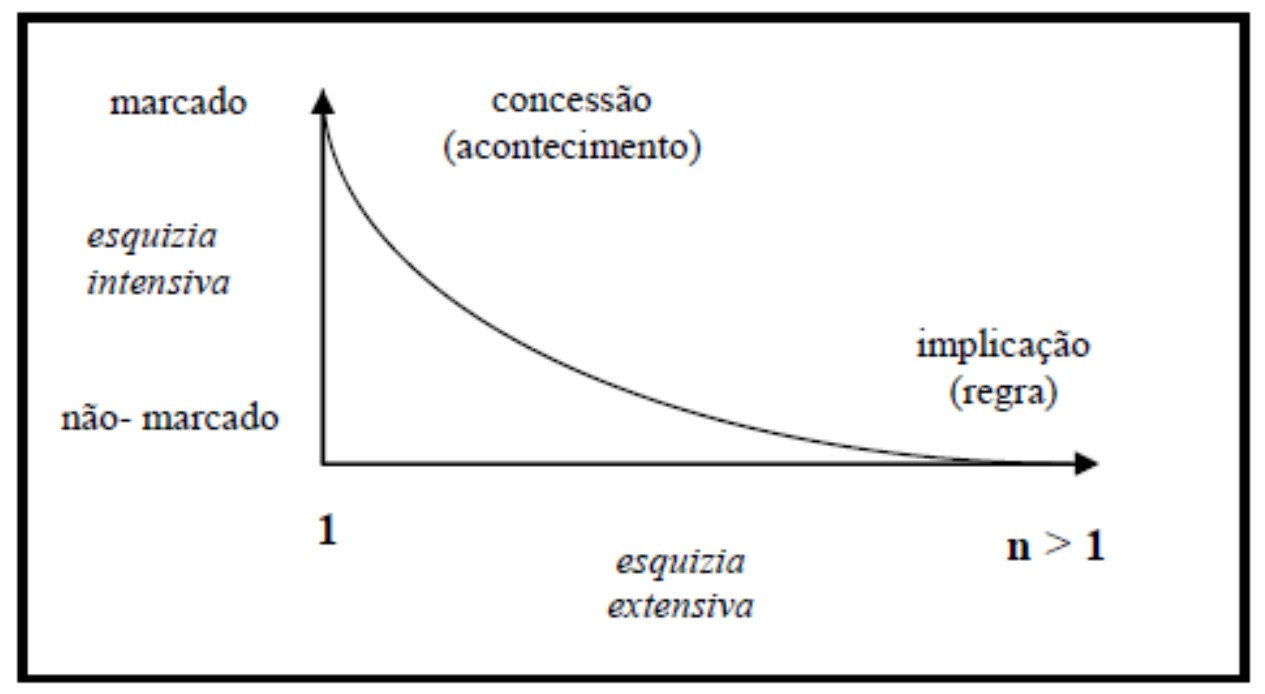

Figura 21. Sintagmas concessivos e implicativos (ZILBERBERG, 2006a, p. 205). 
Reproduzimos, a seguir, o paradigma dos sintagmas elementares da crença, que "se baseia na partilha em sintagmas implicativos correspondentes a alguma doxa e em sintagmas concessivos apartados dessa mesma doxa”, como foi proposto por Zilberberg (Idem, p. 204):

\begin{tabular}{|c|c|}
\hline sintagmas & sintagmas \\
implicativos & concessivos \\
$\downarrow$ & $\downarrow$ \\
\hline crer no acreditável & crer no inacreditável \\
não crer no & não crer no \\
inacreditável & acreditável \\
\hline
\end{tabular}

Figura 22. Paradigma dos sintagmas elementares da crença (ZILBERBERG, Idem, p. 204)

Retomemos o nascimento de Cristo, tal como desenvolvemos no primeiro Capítulo. A maternidade de Maria é tida pelo discurso religioso como uma obra divina que ultrapassa toda compreensão e possibilidade humanas. Ainda que não se admita que uma virgem possa dar à luz um filho, isso é possível no âmbito contratual da fé como obra do Espírito Santo.

Embora a modalidade concessiva (ZILBERBERG, 2004), situada no âmbito do acontecimento, tenha o poder de instaurar um programa dado como irrealizável em outras dimensões, o resíduo mítico impede que se instaure a lógica concessiva na Bíblia. $O$ nascimento miraculoso de Jesus é tido como verdade indiscutível, é palavra revelada, e, portanto, pertencente à doxa, à lógica implicativa do âmbito contratual da fé.

Verificamos como o uso das figuras retóricas produz o efeito de sentido persuasivo e, por conseguinte, os estilos implicativo e concessivo, que remetem a uma aspectualização do sujeito: a) aspectualidade doxal: implicativa - coloca a perfectividade como esperado legal da imperfectividade; b) aspectualidade paradoxal: concessiva - procura a imperfectividade utopia do retorno às origens (ZILBERBERG, 2006a). 
Ressaltamos a liturgia eucarística, cuja análise empreendemos ao longo do segundo Capítulo, ao apresentar uma tensão constante entre as modalidades do conseguir e do sobrevir. Voltemos ao gráfico:

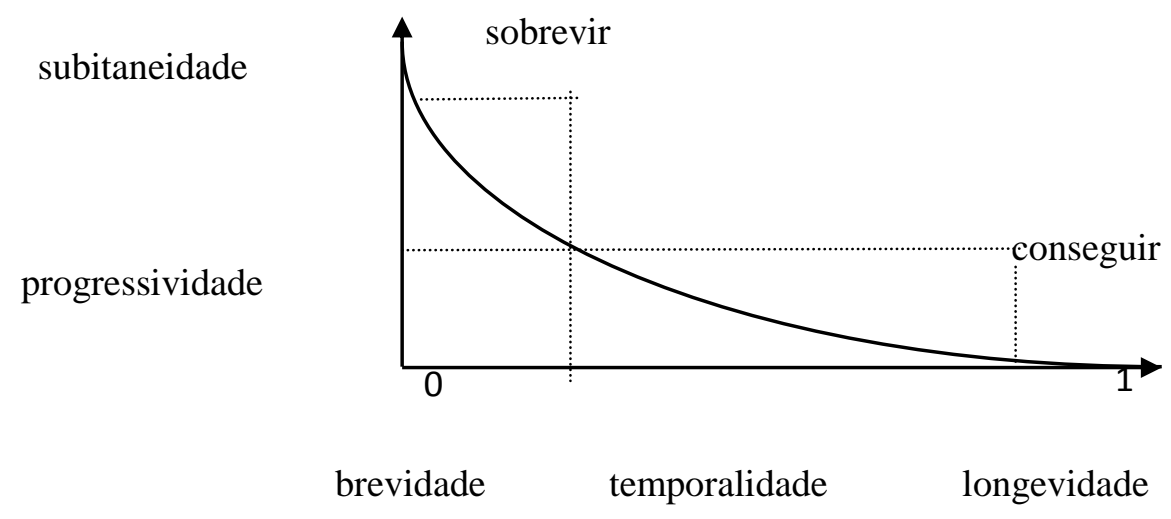

Figura 23. As modalidades do conseguir e do sobrevir (ZILBERBERG, 2006a)

Consoante à implicação, isto é, à doxa, observamos a consagração do pão e do vinho, mediante a transubstanciação das espécies eucarísticas no corpo e sangue de Cristo, consideradas dogma para aquele que crê.

$\mathrm{O}$ acontecimento instaura, nesse momento da missa, um programa dado como irrealizável, a que se contrapõe um contraprograma que leva a termo a sua realização por meio do âmbito contratual através da fé (ZILBERBERG, 2006, p. 148). O enunciado do folheto de missa, suporte do rito eucarístico, ao se situar no eixo do exercício, ou seja, ao conseguir, próprio à lógica implicativa, contrapõe-se ao acontecimento, pautado pela exclamação própria ao sobrevir.

Apresentamos, por intermédio da análise, o quanto se faz necessária a necessidade de um tempo lento a fim de aplacar a perturbação sofrida pelos fiéis diante da emergência do acontecimento. A aceleração, no momento da comunhão, estabelece a parada. A ela se sobrepõe a desaceleração dos gestos e ações sacramentais após a comunhão. A desaceleração, de âmbito participativo, reincorpora o sujeito, que pode, dessa maneira, retomar a continuidade no programa modal de participação do rito eucarístico.

Temos, nessa prática cerimonial, a presença de uma cifra, de um ritmo que reflete o próprio sujeito absorto diante do mistério da fé. Retomemos a orientação apresentada pelo enunciado. Ao manifestar uma direção ascendente a um estado de aceleração máxima [n+1], o 
enunciado do folheto orienta-se para a atenuação do impacto dado mediante a degressividade (projeção no campo de presença de cada vez menos mais [n-1]): Missa: ascendência $\rightarrow$ pico da ascendência $\rightarrow$ descendência.

Voltemos ao gráfico ora proposto:

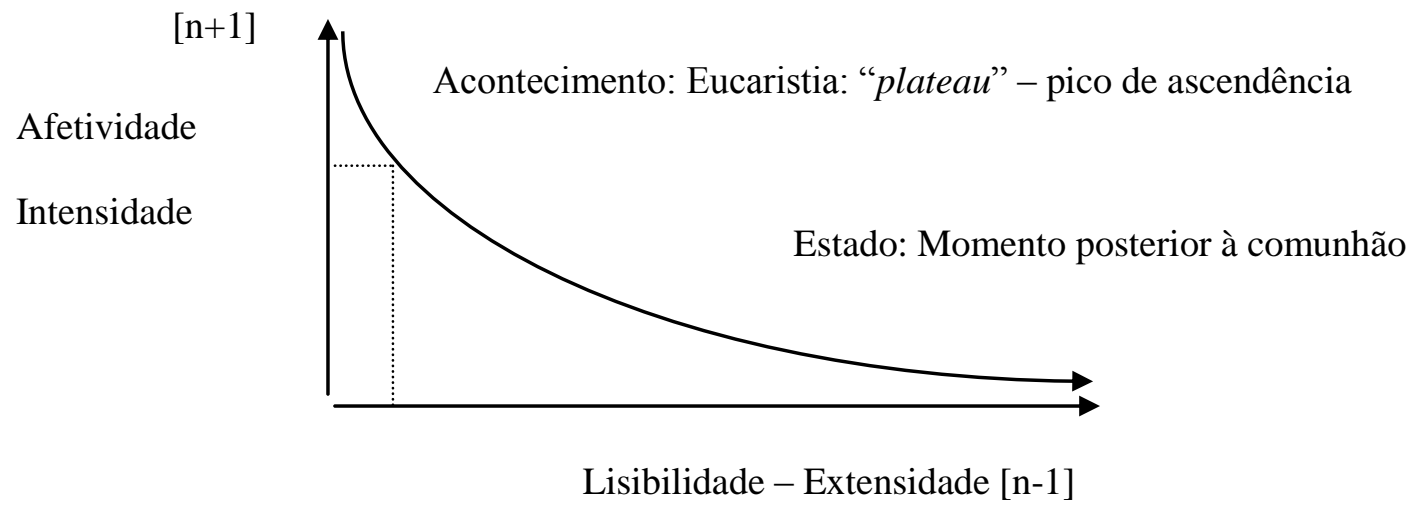

Figura 24. Parte subsequente à eucaristia.

Verificamos, pois, a projeção, no enunciado do rito eucarístico, de um estilo tensivo descendente, degressivo, que segue do "assomo" à "resolução" (ZILBERBERG, 2006a, p. $15)$.

\section{A operacionalização da noção de éthos no domínio religioso: a proposição de uma tipologia calcada no enunciatário}

Procuramos pensar a tipologia dos discursos de fundação, fidelização e divulgação religiosa, relacionando-a aos diferentes modos segundo os quais se processualiza o paradigma da crença proposto por Zilberberg (2006a).

Por meio da análise de elementos estilísticos, extraídos de excertos do discurso fundador bíblico, do discurso de divulgação e dos gêneros a que denominamos experiência da palavra, iniciaremos a caracterização das marcas de discursivização, uma vez que os elementos do plano da expressão também são importantes na determinação do sentido dos textos. Tais marcas nos auxiliarão na descrição, por ora preliminar, da associação entre o ponto de vista tensivo e a retórica.

Ao tomarmos como base as definições de Zilberberg (2004, 2006a), realizamos a análise dos funtivos do andamento que perpassam o domínio religioso considerado. Para tanto, retomemos a noção de esquematismo tensivo (Idem, 2004), tal como a abordamos no 
primeiro Capítulo desta tese. Segundo o autor citado, o esquematismo tensivo consiste na mistura de duas ordens ou dimensões, uma dimensão da intensidade (do sensível) e uma dimensão da extensidade (do inteligível). Cada uma dessas dimensões é analisável em valências que segmentam um intervalo de referência, ao que fica associada uma sintaxe específica. Para a dimensão da intensidade, o intervalo de referência [impactante vs. fraco] refere-se a uma sintaxe ascendente ou decadente. Para a dimensão da extensidade, o intervalo de referência [concentrado vs. difuso] opera a sintaxe da extensidade mediante triagens e misturas.

Na concepção de Zilberberg (2006a, p. 171), de um modo mais geral, os linguistas têm optado pela exploração da sintaxe extensiva e reservado a sintaxe intensiva à retórica. Nossa proposta, entretanto, procura se valer tanto de uma quanto de outra, na medida em que ambas são necessárias à determinação do éthos, do estilo dos três níveis de prática no que concerne ao discurso religioso.

Estabelecemos, assim, mediante a recursividade das operações de triagem e de mistura, a concepção do tratamento analítico do afeto por meio da instituição dos estados aspectuais "caracterizados pelas tensões e ambivalências que os modos de existência peculiares à sintaxe discursiva determinam" (ZILBERBERG, 2004, p. 76).

Foram determinados três níveis de práticas no que concerne ao discurso religioso e que serviram de objeto de análise nos Capítulos precedentes.

Sintaxe da intensidade

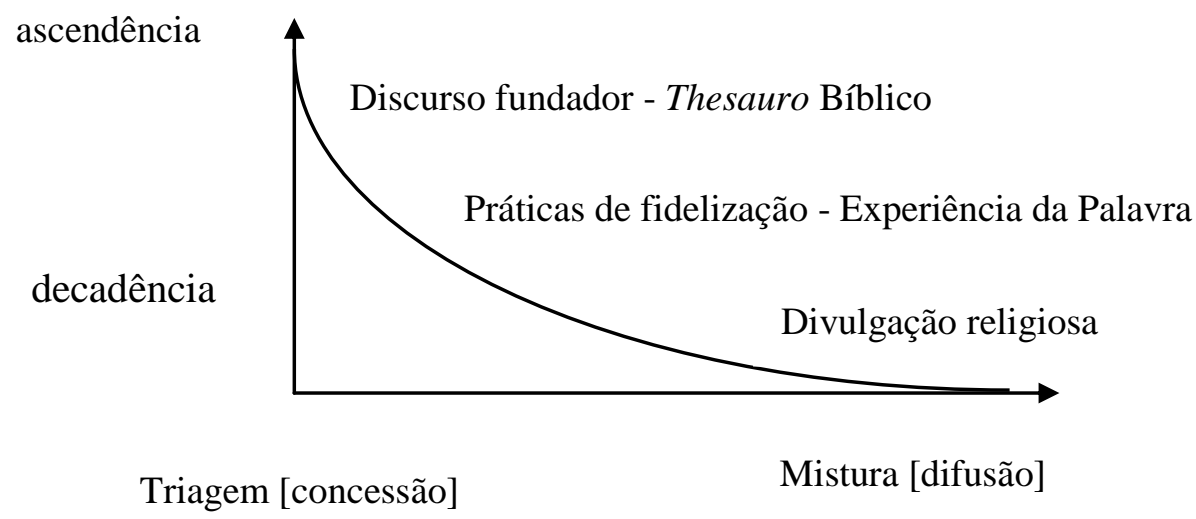

Sintaxe da extensidade

Figura 25. Os três níveis de prática no que concerne ao discurso religioso: fundação, fidelização e divulgação. 
A recursividade das operações de mistura implica operações de triagem que lhe são pressupostas. "Todo o ponto de vista compreende ao mesmo tempo uma acentuação e uma limitação" (ZILBERBERG, 2004, p. 75).

Observamos, no discurso fundador, mediante a análise dos enunciados bíblicos realizados ao longo do primeiro Capítulo desta tese, a prevalência das operações de triagem. Nelas, ressaltamos o predomínio da homogeneidade, da dissociação e do acento mítico, que confirmavam a presença dos valores de absoluto, voltados para a exclusividade e unicidade (ZILBERBERG, 2004, p.90). Ao partirmos do princípio de que a Bíblia consistiria no livro de uma determinada comunidade de fé, para a qual a sua interpretação estaria ligada ao pertencimento do sujeito a uma determinada formação discursiva, ressaltamos o caráter hermético, circunscritivo dessa comunicação intrapares, domínio da triagem, portanto.

Evidenciamos, ainda, a aspectualização incoativa do discurso fundador, cuja organização subjacente é a base para a instituição dos níveis de prática de fidelização e de divulgação.

A análise do discurso fundador dos Atos dos Apóstolos (Capítulo I) tornou possível evidenciar esse caráter incoativo. Isto, pois a narrativa de Atos se estabelece como referência básica para a instituição do domínio de divulgação dos ideais cristãos.

Procuramos levar em conta como se processava a passagem do enunciado bíblico à sua transmissão, seja pelas práticas de fidelização, seja pelas práticas de divulgação.

Delineamos, assim, para o discurso fundador, uma aspectualidade incoativa, que se realiza de forma durativa por meio da celebração periódica das prescrições rituais referentes às práticas de fidelização de uma comunidade de fé e que se temporaliza e se espacializa no discurso de divulgação religiosa.

Procuramos analisar, nos Capítulos subsequentes ao Capítulo I, como são evocadas as cenas validadas (discurso fundador) que situam os enunciados de fidelização e de divulgação religiosa e que tornaram possível a depreensão do éthos católico enquanto um sujeito com caráter próprio.

Destacamos, ao longo do segundo Capítulo desta tese, como se consolida o processo de sistematização e de moralização das práticas e das representações religiosas que vai das Sagradas Escrituras, tidas como discurso fundador, até a sua ritualização pelas práticas religiosas. 
A fidelização religiosa, como rito, ao constituir uma ação programada, da ordem da extensidade, pertence ao eixo do exercício.

Tendo por pressuposto que a recursividade das operações de mistura implica operações de triagem que lhe são pressupostas, notamos a prevalência de operações de triagem na transmissão ritualística intrapares, domínio da comunidade daqueles que partilham da mesma fé.

Verificamos, mediante a análise do gráfico anterior, o quanto a fidelização é mais difusa em relação ao discurso fundador. Assim, para o fundador, ela está mais para a mistura, ao passo que, para a divulgação, ela está mais para a triagem. Nela observamos uma ação programada de espacialidade extensiva, da ordem da difusão.

As práticas de fidelização constituem-se como ações rituais. Retomemos o gráfico apresentado no Capítulo II, que configura a fidelização religiosa enquanto ação programada ${ }^{87}$.

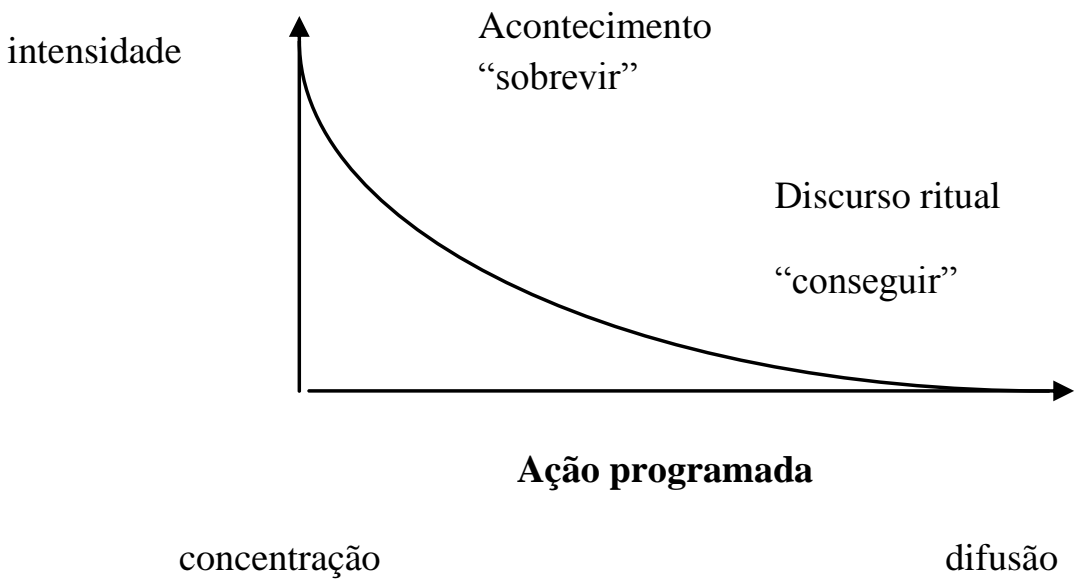

extensidade

Figura 26. Discurso ritual como ação programada.

\footnotetext{
${ }^{87}$ A fim de dispor de uma metalinguagem operatória e adequada, Zilberberg (2007, p. 17-18) admite que "o modo de eficiência designe a maneira pela qual uma grandeza se instala num campo de presença. Se esse processo for efetuado a pedido, segundo o desejo de um sujeito, nesse caso teremos a modalidade do conseguir. Se a grandeza se instala sem nenhuma espera, denegando ex abrupto as antecipações da razão, os cálculos minuciosos do sujeito, teremos a modalidade do sobrevir. [...] O acontecimento é, portanto, essa grandeza estranha, por assim dizer, extraparadigmática, ou melhor, essa grandeza se manifesta a princípio no plano sintagmático por uma antecipação e, desse mesmo fato, espera sua identidade paradigmática".
} 
Tendo por base a função retensiva e circunscritiva, com a prevalência das operações de triagem, própria aos enunciados de fidelização religiosa, estabelecemos uma tipologia que tem por princípio a instituição de três níveis de práticas, dos quais procedemos à análise de seus objetos-suportes. Nessa gradação, temos a eucaristia enquanto ápice da participação em comunidade; a oração, o nível intermediário, e a prática confessional, o seu contraponto mais tônico [+ individual]. Voltemos ao diagrama que apresentamos no segundo Capítulo:

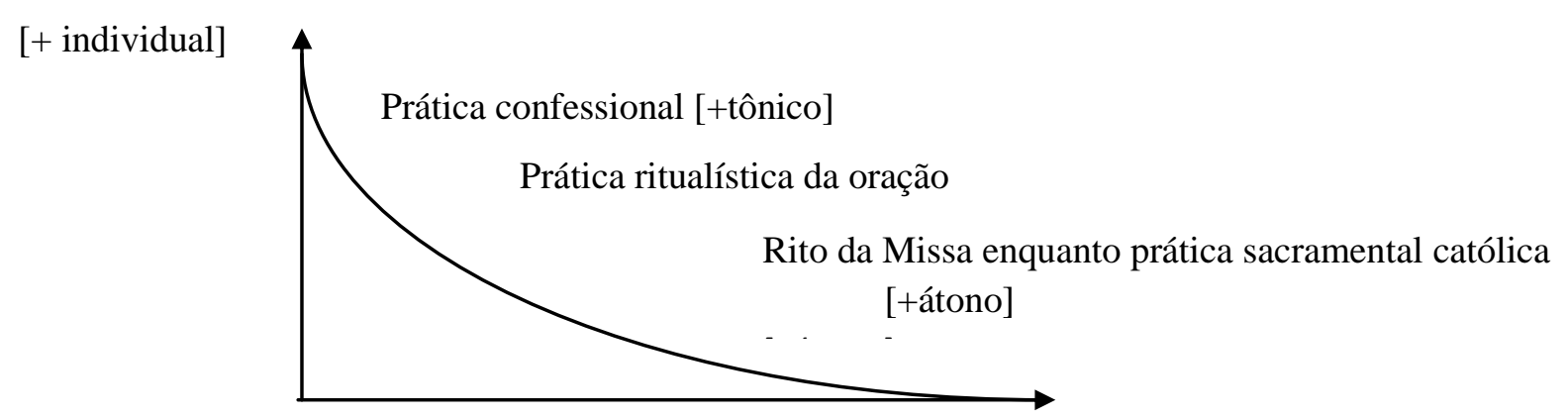

Figura 27. Os três níveis de prática de fidelização religiosa.

[+coletivo]

Inicialmente, tomemos a prática ritualística da oração. Podemos caracterizá-la segundo a direcionalidade tensiva orientada para a concentração espacial e aceleração do andamento. Observamos como a gradação da súplica instituía-se no enunciado da ladainha mediante uma percepção ascendente em tonicidade. É possível delinear, dessa forma, o estilo do enunciado da experiência da palavra (prática católica da oração - ladainha) por intermédio de uma direção ascendente.

Entre os mecanismos de vivência sensível da Palavra, enquanto prática de fidelização religiosa, ressaltamos o enunciado do folheto litúrgico, suporte do rito eucarístico, enquanto prática sacramental católica. Procuramos destacar, por meio da análise empreendida, como a memória figurativa da Última Ceia, ao ser trasposta ao corpo textual e discursivo do rito eucarístico, caracterizava a vigência de um protocolo, de uma ação programada, cuja continuidade temporal e espacial, em uma cadeia ininterrupta de enunciações, localizá-la-ia no domínio da extensidade. A noção de actante coletivo em si, em referência à comunidade de fiéis, enfatiza a atitude participativa enquanto domínio da extensidade. A própria espacialização do templo, espaço sagrado das práticas do rito eucarístico, ao instituir a sua disposição em quatro partes (sacrário, presbitério, naves e átrio), em uma gradação que vai de 
um maior acento sacralizado à sua atonização [+profano], institui-se dentro do âmbito da triagem.

Por fim, o folheto preparatório de confissão [+individual] e, por princípio, [+ tônico] apresenta a exposição das práxis do penitente segundo uma concepção descendente, pertencente à lógica implicativa, se comparado ao ato de confessar.

Como delienar o éthos das práticas de fidelização, gêneros de fronteira entre a fundação e a divulgação, senão pela altivez de um éthos dogmático na proposição de condutas rituais a ser seguidas por um sujeito movido pela paixão da resignação?

Tomemos a sintaxe da extensidade, ao verificar "a divisão das grandezas em classes enumeráveis e a instabilidade dessa divisão” (ZILBERBERG, 2004, p. 73). Uma classe compreende $[n]$ termos, mas pode ganhar outros $[n+1]$ ou perder outros termos $[n-1]$.

Temos, por fim, a tipologia dos discursos de divulgação, objetivo maior desta tese.

Verificamos que nos enunciados de divulgação, dos quais nos ocupamos no terceiro Capítulo da tese, há o predomínio daquilo que Zilberberg (2007) denomina "partilha da veridicção", por neles prevalecerem a propagação e difusão de saberes, crenças e ideais de uma formação discursiva determinada. Tomamos o espaço tensivo, estabelecido pela correlação entre os eixos da intensidade e da extensidade, relacionando-os aos estilos enunciativos de retenção e divulgação. Observamos, para o estilo da divulgação, como se instituía a pertinência da extensidade, dada mediante uma espacialidade difusora, ocupante, contrária a uma espacialidade circunscritiva, própria à retenção.

Reapresentemos o esquema:

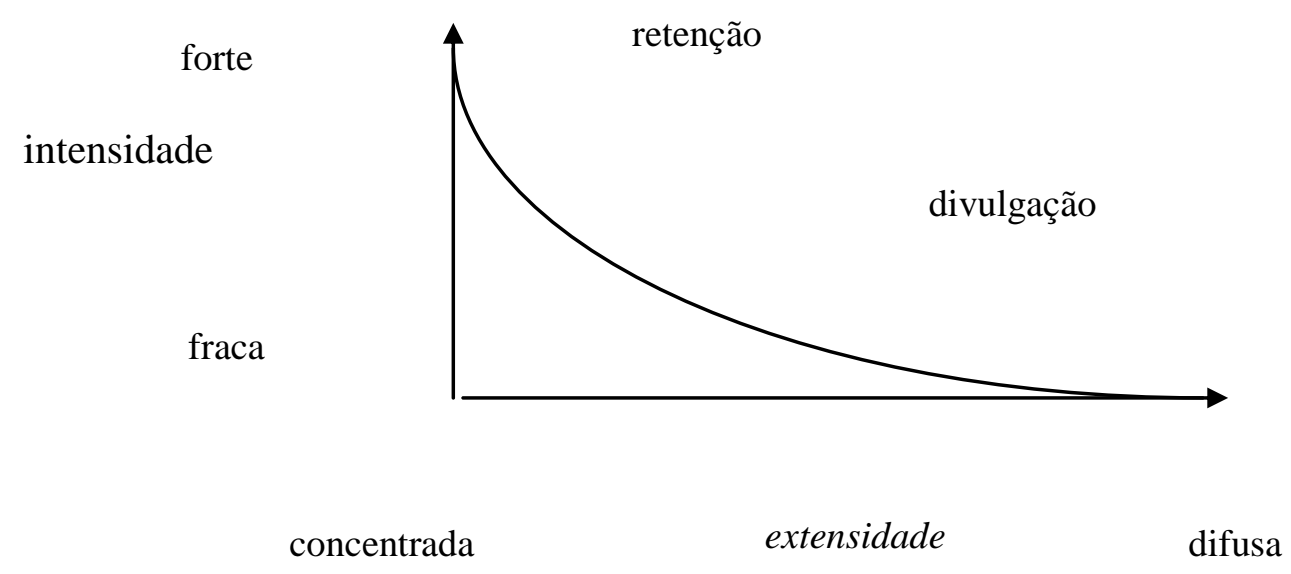

Figura 28. Esquema tensivo da divulgação (ZILBERBERG, 2007, p. 15). 
Essa expansão pode ser verificada em relação ao preenchimento de lacunas semânticas. O fiel tem de ser orientado e ensinado; assim, faz-se necessário que se privilegie o contínuo, de modo que a previsibilidade o sustente com segurança. Os textos da totalidade de divulgação são agrupados segundo elementos extensos. $\mathrm{O}$ andamento tende, tal como o estilo, a apresentar marcas de aceleração. Os enunciados divulgadores se caracterizariam enquanto um fazer interpretativo sobre um discurso primeiro, ao qual designamos discurso fundador. Neles, duas categorias de perfomance fazem-se evidentes: um fazer comunicativo ou persuasivo e um fazer interpretativo, mediante o qual eles interpretariam o enunciado fundador tomado como objeto. Dentro dessa perspectiva, ressaltamos a ambivalência da posição do agente religioso, ao mesmo tempo destinatário do arquidestinador divino e destinador em relação ao fiel.

Destacamos o caráter inovador da tipologia proposta, na medida em que a realizamos tendo por princípio o enunciatário almejado. Esse princípio está plenamente de acordo com o que propõe a retórica, dado que o páthos, as paixões do auditório, constitui uma das provas mais importantes da teoria da argumentação. Para a retórica, o auditório constitui o conjunto de todos aqueles que o orador deseja influenciar por intermédio de seu discurso (PERELMAN, 1984, p. 237).

O orador deve ter do seu auditório uma idéia tanto quanto possível próxima da realidade, uma vez que um erro sobre este ponto pode ser fatal para o efeito que ele quer produzir; é em função do auditório que toda a argumentação se deve organizar, se esta quiser ser eficaz (Idem, ibidem).

Situamo-nos no domínio da teoria semiótica ao instituir o enunciatário como uma das instâncias do sujeito da enunciação, ressaltando o seu papel de co-enunciador.

Com efeito, a imagem do enunciatário constitui uma das coerções discursivas a que obedece o enunciador: não é a mesma coisa produzir um texto para um especialista numa dada disciplina ou para um leigo; para uma criança ou para um adulto. O enunciatário é também uma construção do discurso. Não é o leitor real, mas um leitor ideal, uma imagem de leitor produzida pelo discurso (FIORIN, 2008, p. 153).

Estabelecemos, assim, como o conteúdo seria indissociável do éthos do corpo enunciante que seria próprio a essa totalidade de discursos. Notemos o quanto a dimensão da 
extensidade, segundo a qual o intervalo de referência [concentrado vs. difuso], ao operar a sintaxe da extensidade mediante triagens e misturas, apresenta fundamental importância para a constituição da tipologia ora proposta.

Definimos uma tipologia que tem por princípio a instituição de cinco cenas enunciativas diferenciadas, de cujos enunciados procedemos à análise. Propomos estabelecer, desse modo, recorrências que compunham a materialização discursiva da totalidade, a enunciação de divulgação enquanto éthos. Examinamos as cinco cenas enunciativas, tendo como base os elementos da sintaxe extensiva, triagens e misturas.

a) Divulgação religiosa especializada (A);

b) Divulgação religiosa instrucional (B);

c) Divulgação para conscientização social (C);

d) Divulgação religiosa propagandista (D);

e) Divulgação religiosa midiática (E).

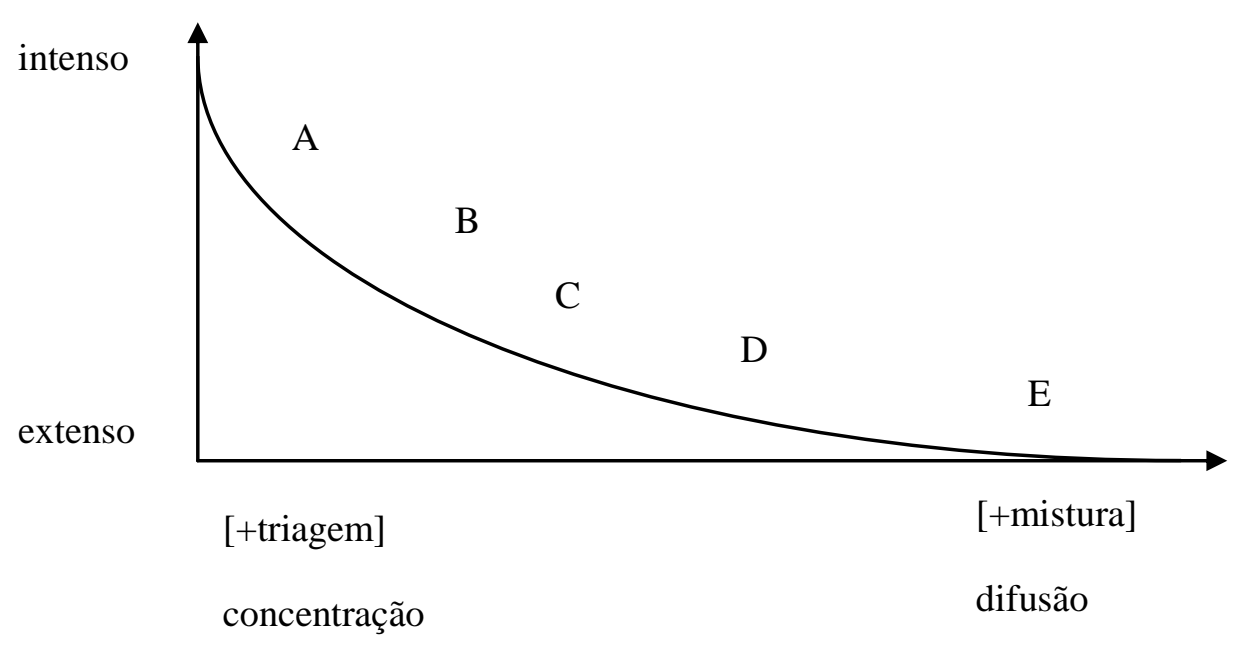

Figura 29. Tipologia dos discursos de divulgação religiosa.

Se a extensidade opera a divisão das grandezas em classes enumeráveis e a instabilidade dessa divisão (ZILBERBERG, 2004, p. 73), como caracterizar a composição de uma classe no domínio religioso de divulgação? Ainda segundo o autor, uma dada classe 
compreende [n] termos, que podem sofrer o acréscimo de outros termos [n+1] ou a supressão de outros [n-1].

Zilberberg (Idem, p. 76) apresenta a instituição de quatro estados aspectuais “caracterizados pelas tensões e ambivalências que os modos de existência peculiares à sintaxe discursiva determinam” (Idem, p. 76): a separação, a continuidade, a mescla e a fusão.

Tomemos a representação proposta pelo autor (Idem, ibidem):

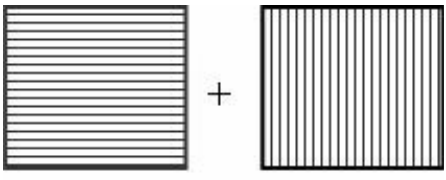

separação

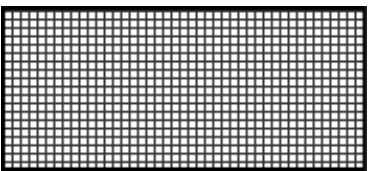

mescla

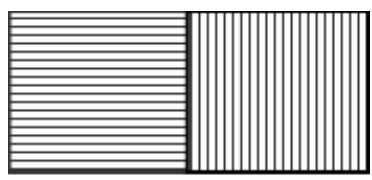

contigüidade

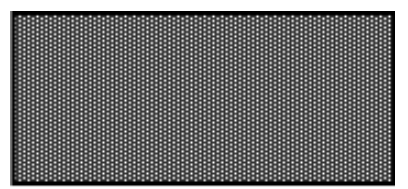

fusão

Figura 30. Quatro estados aspectuais (ZILBERBERG, 2004, p. 76).

A recursividade das operações de triagem e mistura é determinante para o estabelecimento dos estados aspectuais elencados. Ressalta o autor que, para a separação, há a plenitude [1] da valência da triagem [t], o que fornece a designação [ $\left.\mathrm{t}_{1}\right]$, por oposição a uma valência de mistura $[\mathrm{m}]$ nula [0], cuja representação é $\left[\mathrm{m}_{0}\right]$. Na contiguidade, a triagem domina a mistura: $[\mathrm{t} \geq \mathrm{m}]$, ao passo que, na fase da mescla, a triagem passa de dominante a dominada $[\mathrm{t} \leq \mathrm{m}]$. No caso da fusão, inversamente à separação, temos nula a valência da triagem $\left[\mathrm{t}_{0}\right]$ e plena a valência da mistura $\left[\mathrm{m}_{1}\right]$ (Idem, p. 77).

Propomos, assim, associar esses estados aspectuais ${ }^{88}$ às cinco cenas enunciativas de divulgação propostas, tendo como ponto de partida a apreensão sintagmática marcada pela progressividade e pela série, tal como proposto pelo autor (Idem, ibidem).

\footnotetext{
88 “Toda aspectualização de um devir é condicionada pelo andamento, e tanto a análise quanto a síntese são condicionadas pela lentidão. O processo de mistura pode, conforme o caso, ser mais lento ou mais acelerado: neste, a síncope da contigüidade e da mescla transformam o advir em sobrevir, já que o processo passa sem transição, e principalmente sem retardamento para o observador, da separação à fusão" (ZILBERBERG, 2004, p. 77).
} 


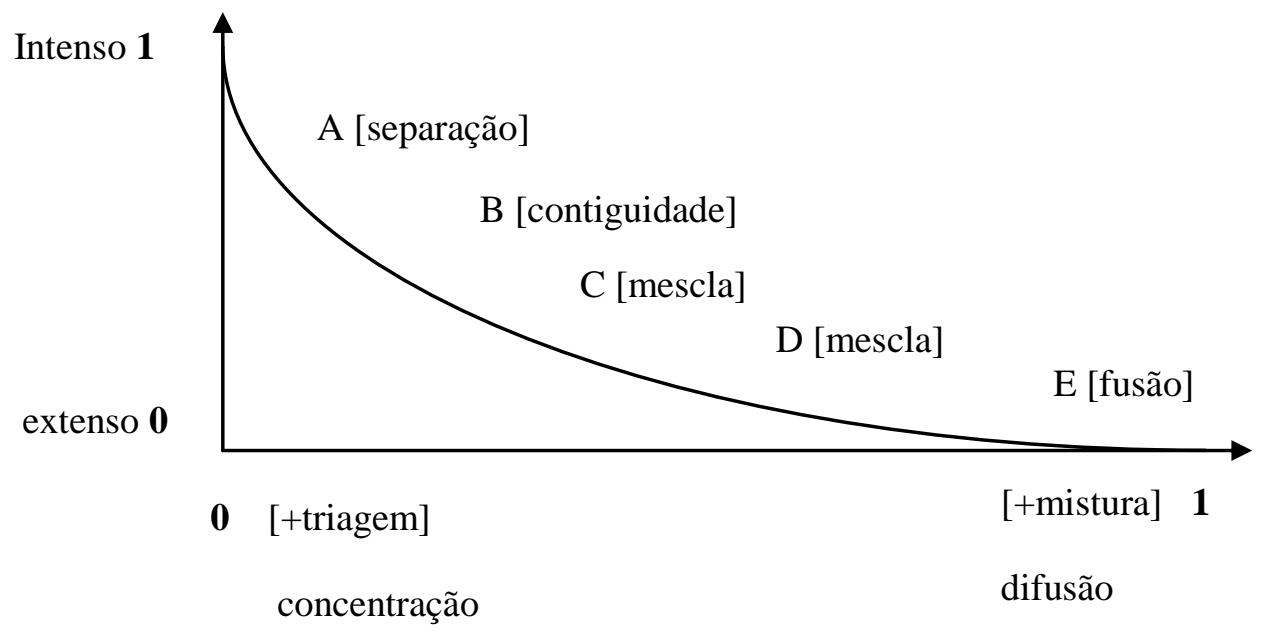

Figura 31. Tipologia dos discursos de divulgação religiosa.

Vejamos como esses estados aspectuais podem ser associados às cenas enunciativas da divulgação religiosa. Para tal fim, consideremos as operações elementares da mestiçagem, na medida em que esta constitui progressivamente uma gramática. Pensemos a mistura, portanto, como uma mistura de dois termos [a $+b]$, à qual se pretende incorporar um elemento [c], e de cujo resultado obteríamos $[(a+b)+c]$ (Idem, p. 82).

Para a divulgação especializada (A), intrapares, determinada pela estabilidade de lugares definidos mediante a instituição de um agente de prestígio, no caso o papa, dirigido aos bispos e aos leigos em geral, teríamos o estado aspectual da separação, pautado pelo predomínio da triagem e da dissociação. Essa dissociação seria determinada pela posição de prestígio do agente religioso, máxima autoridade da Igreja Católica, disposto em um grau hierárquico diferenciado daqueles a quem ele se dirige. Em relação à divulgação instrucional (B), que simula o diálogo e a aproximação entre catequista e catequizando temos a contiguidade, com predomínio das operações de triagem sobre as de mistura. Tanto para a divulgação de conscientização social, quanto para a divulgação propagandista, há o predomínio da mescla, embora em grau diferenciado. No que tange à divulgação para conscientização social, a conversão e posterior adesão seria realizada entre os membros de uma mesma comunidade de fé, o que caracterizaria, portanto, uma operação de mistura por participação. "Apreendemos a mistura como transferência-transporte de uma determinada grandeza [b], por exemplo, de uma classe para outra classe receptora" (ZILBERBERG, 2004, p. 83). Na mistura por participação, uma grandeza [b] é transferida para a classe $\mathrm{C}_{2}$, sem 
deixar de pertencer à classe $\mathrm{C}_{1}$. Assim sendo, o sujeito católico, embora tenha sido convertido à adesão às práticas sociais determinadas pela campanha da fraternidade, não deixa de pertencer ao domínio da formação discursiva católica. Diferente é o que observamos em relação à divulgação propagandista, caracterizada pela mistura por privação, "na qual a transferência põe fim, pelo menos provisoriamente, à subordinação da grandeza [b] à classe C1” (Idem, ibidem). Verificamos, nessa cena enunciativa de divulgação, a passagem, mediante adesão e conversão, de um sujeito de uma formação discursiva a outra, no caso em análise, da formação considerada "falsa", à religião verdadeira (TJ). Vejamos:

$$
\frac{\left[\left[\mathrm{C}_{1} \rightarrow \mathrm{a}, \mathbf{b}, \mathrm{c}, \mathrm{d}\right]-\left[\mathrm{C}_{2} \rightarrow[\mathrm{e}, \mathrm{f}, \mathrm{g}, \mathrm{h}]\right] \rightarrow\left[\left[\mathrm{C}_{1} \rightarrow[\mathrm{a}, \mathrm{c}, \mathrm{d}]-\left[\mathrm{C}_{2} \rightarrow[\mathbf{b}, \mathrm{e}, \mathrm{f}, \mathrm{g}, \mathrm{h}]\right]\right.\right.\right.}{\text { Situação inicial }}
$$

Figura 32. Mistura por privação (ZILBERBERG, 2004, p. 83).

Para a divulgação midiática, há o predomínio da fusão. Isso, pois mesclam-se os espaços do sagrado e do profano, a fim de que se atinja um número ainda maior de fiéis. Ressaltamos, entretanto, o quanto a divulgação midiática, embora nela haja o predomínio das operações de mistura, a sua circunscrição a um público específico, dada por meio de assinaturas, não deixa de revelar elementos próprios à triagem, característicos do domínio religioso.

Atentemos, a seguir, à caracterização do éthos de cada uma dessas cenas enunciativas, determinados por intermédio dos resultados de nossas análises. A divulgação especializada (A) tem como característica a direcionalidade tensiva orientada para a retenção espacial. Projetamos o papel específico do éthos do enunciador, orientado por meio de um tom de voz próprio a um intelectual cristão que procura defender, construir e transmitir as bases de sua doutrina.

Para a divulgação instrucional (B), fez-se a projeção de um éthos professoral e de tom de voz altivo dado por um efeito de um didatismo peculiar.

Em relação à divulgação para conscientização social (C), temos o ressurgimento da polêmica, por meio da instituição de um éthos que só se constitui em relação ao ponto de vista determinado enquanto simulacro a ser rechaçado, dentro do sistema de coerções semânticas 
em que esse discurso se institui. O mesmo ocorre com a divulgação religiosa propagandista (D), com a diferença de que, além do ressurgimento da polêmica, ele tem por objetivo principal a adesão ao novo sistema de valores proposto na prática do discurso de uma nova formação discursiva, no caso, um domínio religioso distinto.

Por fim, para a divulgação midiática (E), procuramos demonstrar como se processa o diálogo entre campos (divulgação religiosa/divulgação científica), dado por uma atitude responsiva e do posicionamento aos temas propostos. Mais do que simplesmente informativo, emerge um éthos mediador daquele que orienta e determina ao leitor instituído (páthos) quais comportamentos adotar e quais posicionamentos seguir. 


\section{CONCLUSÃO}

A peroração compõe-se de quatro partes: a primeira consiste em dispor bem o ouvinte em nosso favor e em dispô-lo mal para com o adversário: a segunda tem por fim amplificar ou atenuar o que se disse; a terceira, excitar as paixões no ouvinte; a quarta, proceder a uma recapitulação.

Aristóteles $^{89}$

${ }^{89}$ ARISTÓTELES (2005, p. 220). 
Expandir o conceito retórico tradicional de éthos, para além do conceito de persuasão, enquanto parte constitutiva da cena da enunciação, associando-o à noção de estilo, tal como desenvolvida por Discini (2004b) consistiu a base necessária para que pudéssemos proceder à articulação da noção de estilo e de éthos à semiótica tensiva. Ao inserirmos nossa tese naquilo que se procurou denominar "tensividade fórica", prefiguração profunda do nível de précondições da significação como um patamar de "pré-sentimento", segundo o qual seria possível entrever um sujeito operando a escolha de valores de continuidade (euforia) ou de descontinuidade (disforia), antes mesmo da operacionalização de configurações modais, actanciais ou temático-figurativas (TATIT, 1997, p. 26), tornou possível a aproximação entre o ponto de vista proposto pela semiótica tensiva e a retórica. Nessa direção procuramos associar a noção de estilo desenvolvida por Discini (2004b) ao ponto de vista tensivo proposto por Zilberberg (2006a) em referência às noções de estilo ascendente e descendente propostas pelo autor. Nossa tese se insere nessa perspectiva de retorno que a semiótica vem empreendendo em relação à retórica. Aproximando a retórica da semiótica, foi possível estudar as partes componentes do sistema retórico como o aparato teórico da semiótica greimasiana, cuja análise dos mecanismos sintáticos do discurso tornou possível a operacionalização do conceito de éthos segundo as bases tensivas. Nesta tese foram apresentados alguns desses pontos de contato, na medida em que eles tornaram possível atingir os objetivos propostos no que diz respeito à associação entre semiótica tensiva e retórica e no que concerne à noção de estilo.

Aliada a essa problemática teórica, acrescentamos a problemática analítica que fundamenta a proposição de nossa tese. Nossa dissertação de mestrado (RAMOS-SILVA, 2007) havia deixado aberta a possibilidade de ampliar a relação estabelecida entre discursos da totalidade discursiva de divulgação religiosa. Fazia-se necessária também a ampliação da pesquisa a respeito da utilização dos gêneros discursivos correspondentes à divulgação religiosa, no que diz respeito a publicações que não se restringissem unicamente ao caráter doutrinário, de ensino e instrução religiosa. Portanto, a pesquisa em relação à utilização de diversos gêneros de divulgação religiosa (encíclica, compêndio, compêndio didático de estudo bíblico, texto-base da campanha da fraternidade, artigo jornalístico de divulgação religiosa, entrevista), do domínio religioso católico e, quem sabe, até acrescidos de outros discursos, tentou delinear, de forma mais abrangente, a tipologia dos discursos de divulgação religiosa que buscamos propor neste estudo. Para isso, priorizamos o exame dos textos relativos à 
divulgação promovida pela Igreja Católica (IC), textos aproximados com outros, também voltados para a divulgação religiosa, dos quais destacamos aqueles representativos da Igreja Universal do Reino de Deus (IURD) e da Igreja das Testemunhas de Jeová (TJ).

A organização da tese em três conjuntos discursivos - a) discurso fundador; b) discurso de fidelização religiosa; c) discurso de divulgação religiosa - deu-se como resultado da relação entre o trato do material de trabalho enquanto corpus e da análise propriamente dita. Procuramos instituir as particularidades que distinguem esses três níveis de práticas no que concerne ao discurso religioso a partir das análises dos enunciados, mediante a observação das recorrências dos mecanismos de construção do sentido dos enunciados reunidos por ambos os discursos e que foram objeto de análise dos Capítulos deste trabalho. Procurarmos delinear, portanto, mediante a recursividade das operações de triagem e de mistura, o conceito de éthos, o ator da enunciação, na depreensão de uma percepção de mundo mais acelerada, ou menos, que o sujeito tem do mundo discursivizado e observado em cada um desses níveis de práticas.

Tomamos a Sagrada Escritura como objeto de estudo do primeiro Capítulo desta tese a fim de que pudéssemos desvendar o processo de significação do discurso bíblico. Realizamos a análise semiótica de excertos extraídos do Antigo e do Novo Testamento. Procuramos demonstrar como o próprio entendimento da cena fundadora bíblica torna possível depreender o modo de ser e de habitar o espaço social do enunciador responsável por esse discurso. Caracterizamos a Bíblia como discurso fundador de nossa cultura, relato das ações divinas na história, texto fundador de uma religião ou religiosidades, norma a ser seguida pela práxis de uma determinada comunidade de fé. O texto bíblico, considerado como texto de referência primeiro e como discurso fundador dos discursos de fidelização e de divulgação religiosa, devido ao efeito de atemporalidade do discurso religioso, é a base para a discursivização do discurso de divulgação religiosa.

Os resultados de nossa análise se refletem na incorporação de um sujeito modalizado pela paixão fiduciária da crença que, dado o caráter intersubjetivo proposto, institui a relação entre o sujeito e o exercício da própria fé. A esse sujeito, que deixa transparecer partes de seu corpo, na percepção de um mundo discursivizado, propomos associar, com apoio em Discini (2005), a noção de aspectualização do ator da enunciação, à noção de estilo (éthos), o que projeta o papel específico do éthos do enunciador, orientado por meio de um tom de voz próprio à cena enunciativa pressuposta. 
Reservamos o segundo Capítulo da tese para a análise dos enunciados de fidelização religiosa. A formação discursiva, como sistema de crenças e aspirações, fundado em figuras e temas de determinado discurso, e a escolha de recursos relativos à gramática da língua se refletem na incorporação de um éthos dogmático, o que permite caracterizar os enunciados de fidelização, definindo-os segundo os parâmetros da "prática religiosa católica", como gêneros de fronteira entre a divulgação e a fidelização religiosa, que julgamos por bem nomeá-los como pertencentes à "experiência da Palavra". Esses gêneros são voltados para arrebanhar mais e mais fiéis no exercício da própria fidelização.

Ao éthos da resignação associamos o sujeito (fiel) dominado e subjugado pela instituição religiosa e as suas práticas instituídas sob a aparência da unidade. Por sujeito resignado, está o sujeito submisso a essas práticas ritualísticas e que a elas deve se submeter a fim de obter a salvação.

Estabelecemos como objetivo específico do terceiro Capítulo depreender o éthos do enunciador da divulgação religiosa como efeito de sentido de uma totalidade enunciada. Nosso fazer sancionador, responsável pelo recorte e delimitação de totalidades, delineou um conjunto de enunciados de divulgação. Procedemos à formulação de uma tipologia do discurso de divulgação religiosa, calcada no enunciatário e disposta em cinco cenas enunciativas diferenciadas: a) divulgação religiosa especializada; b) divulgação religiosa instrucional; c) discurso para conscientização social; d) divulgação religiosa propagandista; e) divulgação religiosa midiática. A análise dos enunciados que compunham cada uma dessas cenas enunciativas permitiu que depreendêssemos os diferentes níveis hierárquicos segundo os quais se realiza o estilo, o ator da enunciação de tais discursos. Verificamos, assim, que a formação ideológica dos discursos de divulgação religiosa projeta um éthos mediador, de tom de voz próprio daquele que ensina, orienta e dita ao leitor aprendiz (páthos) determinadas regras de conduta de como pensar e proceder por meio de formações discursivas. As formações discursivas agrupam ao longo dos textos de divulgação religiosa temas que refletem diferentes categorizações de mundo, que se materializam através de figuras, em consonância com as restrições de cada totalidade discursiva.

Reservamos para o Capítulo final o espaço necessário para os tópicos teóricos que pretendíamos elencar e que tornariam possível a aproximação e a associação entre o ponto de vista retórico com a semiótica tensiva. Essas questões, ao permitirem a operacionalização da noção de éthos, forneceram as bases necessárias para a depreensão das particularidades que 
tornaria possível, tanto a distinção entre o discurso religioso, o discurso fundador, o discurso de fidelização e o discurso de divulgação religiosa, quanto delinear a tipologia dos discursos de divulgação religiosa proposta nesta tese.

Esperamos assim, termos cumprido os objetivos propostos no que concerne ao desenvolvimento da noção semiótica de estilo com a operacionalização da noção de éthos, bem como evidenciar nosso ponto de vista, que procura desenvolver e expandir os desenvolvimentos ora apresentados, mediante a proposição de uma revitalização da retórica, associando-a ao ponto de vista tensivo da semiótica.

Mediante essas considerações, esperamos poder ter contribuído de alguma forma com o estudo dos discursos de fundação, fidelização e de divulgação religiosa, com o exame da própria esfera de circulação do sentido religioso, ou seja, com reflexões a respeito do discurso religioso, como enunciado, enunciação, éthos e estilo. 


\section{REFERÊNCIAS BIBLIOGRÁFICAS}

AMORIM, Marília.O pesquisador e seu outro:Bakhtin nas Ciências Humanas. São Paulo: Musa Editora, 2004.

AMOSSY, Ruth (org.) Imagens de si no discurso: a construção do ethos. São Pulo: Contexto, 2005.

ARISTÓTELES. Arte Retórica e Arte Poética. 17a. ed. Rio de Janeiro: Ediouro, 2005.

ATOS DOS APÓSTOLOS. Português. In: Bíblia Sagrada: Tradução da CNBB. $6^{\text {a }}$. ed. Trad. Conferência Nacional dos Bispos do Brasil. São Paulo: Edições CNBB, 2007.

AUTHIER-REVUZ, Jacqueline. Hétérogéneité montrée et hétérogéneité constitutive: élements pour une approuche de l'autre dans Le discours. DRLAV, 26. Paris, Centre de Recherche de l'Université de Paris, VIII, 1982, p.91-151.

BAKHTIN, Mikhail. Estética da criação verbal. 4a . ed. São Paulo, Martins Fontes, 2003.

BAKHTIN, Mikhail M./VOLOSHINOV. Marxismo e filosofia da linguagem. $11^{\mathrm{a}}$. ed. Trad. Michel Lahud e Yara Frateschi Vieira. São Paulo: Hucitec, 2004. Original francês.

BARROS, Diana Luz Pessoa de. Teoria do Discurso: Fundamentos semióticos. $3^{\text {a }}$. ed. São Paulo: Humanitas, 2002.

Teoria Semiótica do Texto. São Paulo: Ática, 2005.

Semiótica e Retórica: um diálogo produtivo. In: LARA, Gláucia Muniz Proença Lara; MACHADO, Ida Lúcia; EMEDIATO, Wander. (orgs). Análises do discurso hoje. Vol. II. Rio de Janeiro: Nova Fronteira, 2008.

BASADONNA, G; SANTARELli, G. Ladainhas de Nossa Senhora. São Paulo: Loyola, 2000.

BAUER, Johannes. Dicionário de teologia bíblica. Vol. II. 4ª ed. São Paulo:Loyola, 1988.

BERTRAND, Denis. Caminhos da Semiótica Literária. Bauru-SP: Edusc, 2003.

BENTO XVI, Papa. Carta Encíclica Deus Caritas Est. 9a. ed. São Paulo : Paulinas, 2008.

BENTO XVI. Compêndio do Catecismo da Igreja Católica. São Paulo: Loyola, 2005.

BENVENISTE, Émile. Da subjetividade na linguagem. In: Problemas de Linguística Geral. São Paulo: Editora Nacional, Editora da Universidade de São Paulo, 1976, p.284-293). 
A noção de "ritmo" na sua expressão linguística. In: Problemas de Linguística Geral I. 5a . ed. Campinas, SP: Pontes Editora, 2005, p. 361-370.

BERTRAND, Denis. Caminhos da Semiótica Literária. Bauru, SP: EDUSC, 2003.

BÍBLIA de Jerusalém. São Paulo: Paulus, 2004.

BLANCO, Desiderio. El rito de la Misa como práctica significante. Topicos del Seminário, n. 20, Puelbla/ México: Benemérita Universidad Autónoma de Puebla, pp. 43-70, 2008.

BORDRON, Jean-François; FONTANILLE, Jacques. Introduction. Langages, 34e année, n.137. 2000, pp. 3-15.

BORN, A. Van Den. Dicionário Enciclopédico da Bíblia. 2a . ed. São Paulo: Vozes, 1977.

BORTOLINI, José. A Missa explicada parte por parte. São Paulo: Paulus, 2006a.

Quaresma, Páscoa e Pentecostes. São Paulo: Paulus, 2006 b.

BOURDIEU, Pierre. A economia das trocas simbólicas. São Paulo: Perspectiva, 1974.

A linguagem autorizada: as condições sociais da eficácia do discurso ritual. In: A economia das trocas linguísticas: o que falar quer dizer. São Paulo: EDUSP, 1998, p.85-96.

O espaço dos pontos de vista. In: Os usos sociais da ciência. São Paulo: Editora UNESP, 2004, p. 43-48.

BRANCO, Nanci Moreno. O dialogismo na Encíclica Deus Caritas est, de Bento XVI. In: MIOTELLO, Valdemir (org). Dialogismo: olhares, vozes, lugares. São Carlos: Pedro e João Editores, 2009.

BUENO, Wilson da Costa. Jornalismo Científico: conceito e funções. Ciência e Cultura. São Paulo: SBPC, vol. 37, n.9, p. 1420-1427, set. 1985.

BRUNEL, P. Dicionário de Mitos Literários. Rio de Janeiro: José Olympio, 1997.

CALVEZ, Jean-Yves. A economia, O Homem e a Sociedade: o ensinamento social da Igreja. Trad. Orlando Soares Moreira. São Paulo: Loyola, 1995 (Original Francês).

CAMPBELL, J. O poder do mito. São Paulo: Paulo: Palas Atena, 2005.

CAMPOS, Paulo Roberto. 29 de maio de 2008: um dia trágico na história do Brasil. Catolicismo, São Paulo, ano LVIII, n. 691, p. 40-45, julho, 2008.

CARDEAL ARNS, Paulo Evaristo. O que é Igreja. São Paulo: Brasiliense, 1981.

CAREY, James W. Communication as culture. Essays on media and society. New York: Routledge, 2009. 
CARVALHO, Paulo César de. Fragmentos epistolares de um discurso amoroso: elementos para uma análise semiótica do estatuto do gênero Carta de Amor. Dissertação de Mestrado. São Paulo: Universidade de São Paulo, 2005.

CASSIRER, Ernest. A filosofia das formas simbólicas. Vol. I e II. São Paulo: Martins Fontes, 2001.

CHABROL, C. Problemas de Semiologia Narrativa dos textos bíblicos. In: CHABROL, C; MARTIN, L. Semiótica Narrativa dos textos bíblicos. Trad. de Katia Hakin Chalita. Rio de Janeiro: Forense Universitária, 1980, p. 2, p. 2-12.

CHARAUDEAU, Patrick. Discurso das Mídias. São Paulo: Contexto, 2006.

; MAINGUENEAU, Dominique. Dicionário de Análise do Discurso. São Paulo: Contexto, 2004.

CHAUÍ, Marilena. Brasil: Mito fundador e sociedade autoritária. São Paulo: Editora Fundação Perseu Abramo, 2006.

COHN, Carlos; NASCIMENTO, Lyslei. A Bíblia e suas traduções. São Paulo: Humanitas, 2009.

CONCÍLIO VATICANO II. Gaudium et Spes: Constituição Pastoral do Concílio Vaticano II sobre a Igreja no mundo de hoje. 15ª . ed. São Paulo: Paulinas, 2007.

CONFERÊNCIA Nacional dos Bispos do Brasil - CNBB. Campanha da Fraternidade 2008: Texto-base. São Paulo: Editora Salesiana, 2008.

COSTA, Sergio Roberto. Dicionário de gêneros textuais. São Paulo: Autentica, 2008.

COURTÉS, Joseph. L' énonciation comme acte sémiotique. Nouveaux Actes Sémiotiques 58-59. Pulim, Université de Limoges, 1998.

CUNHA, Antônio Geraldo. Dicionário Etimológico Nova Fronteira da Língua Portuguesa. 2a . ed. Rio de Janeiro: Nova Fronteira, 1982.

DABEZIES, A. Mitos primitivos e mitos literários. In: BRUNEL, P. Dicionário de Mitos Literários. Rio de Janeiro: José Olympio, 1997, p. 731-735.

DELORME, Jean. Analyse Sémiotique du discours et étude de la Bible. In: Sémiotique et Bible, Lyon, Centre pour l'analyse du discours religieux, n. 66, jun. 1992, p. 37-44.

La semiotique greimassienne et les études bibliques. In: ARRIVÉ, Michel et. alii (org.) Nouveaux Actes Semiotiques, n. 25, Limoges- France, Pulim,Université de Limoges, 1993, p. 35-43.

DISCINI, Norma. Ator e Aspecto. Caderno de Discussão do Centro de Pesquisas Sociossemióticas, 2004a. 
Disponível em:www.pucsp.br/pos/cos/cps/arquivo/arqs/PDF/colo2004/Norma_Atorpdf. Acesso em: 30 de Nov. de 2011.

. O estilo nos textos. São Paulo: Contexto, 2004b.

Identidade e Modo de Presença. In: II Congresso Internacional- Brasil, Identidade e alteridade. Anais. N.2. vol.1. São Paulo: Associação Brasileira de Estudos Semióticos, 2005a. 1 CD-ROM .

A Comunicação nos textos. São Paulo: Contexto, 2005b.

.Diário e Carta: Questões de Gênero e Estilo, 2005c. Cópia xeróg.

Da presença sensível. In: Cadernos de Semiótica Aplicada, vol. 8, n.2, dezembro de 2010. Disponível em: http://seer.fclar.unesp.br/casa/article/view/3330. Acesso em: 30 nov. 2011.

Ethos e Estilo. In: MOTTA, Ana Raquel; SALGADO, Luciana (orgs.). Ethos discursivo. São Paulo: Contexto, 2008.

DUBOIS, Jean; et alii. Retórica Geral. Tradução de Carlos Felipe Moisés, Duílio Colombini e Elenir de Barros. São Paulo: Cultrix; Ed. da Universidade de São Paulo, 1974.

Dicionário de Linguística. São Paulo: Cultrix, 2001.

DURKHEIM, Émile. As formas elementares da vida religiosa. São Paulo: Martins Fontes, 2003.

ECO, Umberto. A vertigem das listas. São Paulo: Record, 2010.

ELIADE, M. Tratado de História das Religiões. São Paulo: Martins Fontes, 1993.

Mito e realidade. São Paulo: Perspectiva, 2004.

FERREIRA, Aurélio Buarque de Holanda. Novo Dicionário Aurélio da Língua Portuguesa. $3^{\mathrm{a}}$. ed. Rio de Janeiro: Regis, 2004 corresponde à $3^{\mathrm{a}}$. edição, Rio de Janeiro: Nova Fronteira; Positivo, 2004. CD-ROM.

FIORIN, José Luiz. O regime de 1964: Discurso e Ideologia. São Paulo: Atual, 1988.

. A lógica da neutralidade: um caso de aspectualização do ator. Estudos Linguísticos. XVIII Anais de seminários do GEL. Lorena: Prefeitura Municipal de Lorena, 1989. p. 348355.

Semântica estrutural: o discurso fundador. In: OLIVEIRA, Ana Cláudia Mei Alves de; LANDOWSKI. Do inteligível ao sensível: em torno da obra de Algirdas Julien Greimas. São Paulo: EDUC, 1995, p. 17-42.

As astúcias da enunciação. São Paulo: Ática, 2002. 
O éthos do enunciador. In: CORTINA, Arnaldo; MARCHEZAN, Renata Coelho (orgs). Razões e sensibilidades: a semiótica em foco. Araraquara: Laboratório Editorial/FCL/UNESP; São Paulo: Cultura Acadêmica Editora, 2004, p. 117-138.

Em busca do sentido: estudos discursivos. São Paulo: Contexto, 2008.

FLOCH, Jean-Marie. Petites mythologies de l'oeil et de l'esprit: pour une sémiotique plastique. Paris/Amsterdam: Hadés/Benjamins, 1985.

FOLHA UNIVERSAL. Médicos Contra o Vaticano. São Paulo, 22 de março de 2009, p. 1415.

FONTANILlE, Jacques. Semiótica do discurso. Trad. Jean Cristtus Portela. São Paulo: Contexto, 2007.

Práticas Semióticas: Imanência e pertinência, eficiência e otimização. In: Diniz, Maria Lúcia Visotto Paiva; Portella, Jean Cristtus (orgs). Semiótica e Mídia: textos, práticas e estratégias. Bauru: UNESP/FAAC, 2008.

FONTANILlE, Jacques; ZILBERBERG, Claude. Tensão e significação. São Paulo: Humanitas, 2001.

FOUCAULT, Michel. O que é um autor? 3a . ed. Lisboa: Passagens, 1997.

GREIMAS, Algirdas Julien. Du Sens. Paris: Seuil, 1970.

Semântica Estrutural. São Paulo: Cultrix, 1973.

De la colère. In : GREIMAS, Algirdas Julien. Du Sens II : Essais Sémiotiques. Paris : Éditions Du Seuil, 1983a.

. Le savoir et le croire: um seul univers cognitif. In : GREIMAS, Algirdas Julien. $D u$ Sens II : Essais Sémiotiques. Paris : Éditions Du Seuil, 1983b.

. Folclore, religião e história. Trad. Ana Maria Petraitis Liblik. Significação: revista brasileira de estudos semióticos, São Paulo, n. 21, p. 9-28, junho, 2004 (Original Lituano).

GREIMAS, Algirdas Julien; COURTÉS, Joseph. Dicionário de Semiótica. São Paulo: Contexto, 2008.

Sémiotique: dictionnaire raisonné de la théorie du langage. Tome 2. Paris: Hachete, 1986.

; FONTANILLE, Jacques. Semiótica das Paixões. São Paulo: Ática, 1993.

GRILLO, Sheila.V.C. A divulgação científica na esfera midiática. Intercâmbio (CD-ROM), v.15, p. 1-10, 2006 .

Esfera e Campo. In: BRAIT, Beth. Bakhtin: outros conceitos-chave. São Paulo: Contexto, 2006b. 
HABERMAS, Jürgen. O futuro da Natureza Humana: a caminho de uma eugenia liberal? Trad. Karina Janini. São Paulo: Martins Fontes, 2004. Original alemão.

HJELMSLEV, L. Prolegômenos a uma teoria da linguagem. São Paulo: Perspectiva, 1975.

HOUAISS, Antonio. Dicionário Eletrônico Houaiss da Língua Portuguesa. São Paulo: Objetiva, 2010. Cd.Rom.

JADON, José Carlos. A ideologia do sucesso: Uma análise semiótica do discurso televisivo da Igreja Universal do Reino de Deus. Dissertação de Mestrado. São Paulo: Universidade Presbiteriana Mackenzie, 2005.

JAKOBSON, Roman. Linguística e Comunicação. São Paulo: Cultrix, 1969.

JOÃO PAULO II, Papa. Catecismo da Igreja Católica: edição típica vaticana. São Paulo: Loyola, 2000.

Evangelium Vitae: Carta Encíclica de João Paulo II sobre o valor e a inviolabilidade da vida humana. $5^{\text {a }}$. ed. São Paulo: Paulinas, 2005.

KATER FILHO, Antonio Miguel. O Marketing aplicado à Igreja Católica. São Paulp : Loyola, 1994.

KRIEG-PLANQUE, A. A noção de fórmula em análise do discurso - quadro teórico e metodológico. Trad. Luciana Salazar Salgado e Sírio Possenti. São Paulo: Parábola Editorial, 2010.

KURTZ, William. Atos dos Apóstolos. In: BERGANT, Diane; KARRIS, Robert (orgs.). Comentário Bíblico. Vol. III. São Paulo, Loyola, 1999, p.143-174.

LANDOWSKI, Eric. Passions sans nom. Paris: Presses Universitaires France, 2004.

LOWERY, Daniel L. Dicionário Católico Básico. 2a. Ed. Aparecida, SP : Editora Santuário, 1999.

MAINGUENEAU, Dominique.Approche de l'enunciation em linguistique française : Embrayers, Temps. Discours rapporté. Paris : Hachette, 1981.

Novas Tendências em Análise do Discurso. $3^{\text {a }}$.ed. Campinas: Pontes, 1997.

A Gênese dos discursos. Trad. Sírio Possenti. Curitiba: Criar Edições, 2005a. Original francês.

.Ethos, Cenografia, Incorporação. In: AMOSSY, Ruth (org.). Imagens de si no discurso: a construção do ethos. São Paulo: Contexto, 2005b.

Termos-Chave da Análise do Discurso. Belo Horizonte: Editora da UFMG, 2006.

A propósito do ethos. In: MOTTA, Ana Raquel; SALGADO, Luciana (orgs.). Ethos discursivo. São Paulo: Contexto, 2008a. 
Cenas da Enunciação. São Paulo: Parábola Editorial, 2008b.

Polifonia e Cena da Enunciação na pregação religiosa. In: LARA, Gláucia Muniz Proença; MACHADO, Ida Lúcia; EMEDIATO, Wander (orgs.). Análises do discurso hoje, vol. 1. Rio de Janeiro: Nova Fronteira, 2008c, p. 199-218.

MARCUSCHI, Luiz Antônio. Gêneros Textuais: definição e funcionalidade. In: DIONISIO, Angela Paiva; MACHADO, Ana Rachel; BEZERRA, Maria Auxiliadora (orgs). Gêneros textuais e ensino. Rio de Janeiro: Lucerna, 2003, p. 19-36.

MARGUERAT, Daniel. A primeira história do cristianismo: os Atos dos Apóstolos. São Paulo: Loyla, 2003.

MARTINO, Luís Mauro Sá. Mídia e poder simbólico: Um ensaio sobre comunicação e campo religioso. São Paulo: Paulus, 2003.

MEDEIROS, Maria do Carmo Ivo de. Duas leituras do Fórum Social Mundial: Caros Amigos e Catolicismo. Dissertação de Mestrado. Campinas- SP: Universidade Estadual de Campinas, 2004.

MENDES, Mariza B. T. No princípio era o poder. Uma análise semiótica das paixões no discurso do Antigo Testamento.São Paulo: Abbablume/FAPESP, 2009.

MENDES, Conrado Moreira; SILVA, Sueli Maria Ramos. ZILBERBERG, Claude. Elements de grammaire tensive. Limoges: PULIM, 2006. 244. In: Cadernos de Semiótica Aplicada, Vol. 7.n. 2, dezembro de 2009. Disponível em: http://seer.fclar.unesp.br/casa/article/viewFile/2227/1834. Acesso em: 29 nov. 2011. Resenha.

MERLEAU-PONTY, Maurice. Fenomenologia da Percepção. São Paulo, Martins Fontes, 1994.

MEYER, Michel. A Retórica. São Paulo: Ática, 2007.

MOSCA, Lineide do Lago Salvador (org). Retóricas de ontem e de hoje. $3^{\text {a }}$. ed. São Paulo: Associação Editorial Humanitas, 2004.

MOTTA, Ana Raquel. Fórmulas discursivas. São Paulo: Contexto, 2011.

O POVO DE DEUS EM SÃO PAULO. Folheto de Missa: Semanário LitúrgicoCatequético. São Paulo: Mitra Arquidiocesana de São Paulo, 2010.

O QUE A BÍBLIA REALMENTE ENSINA. São Paulo: Sociedade Torre de Vigia de Bíblias e Tratados, 2006.

O QUE DEUS requer de nós. São Paulo: Sociedade Torre de Vigia de Bíblias e Tratados, 1996.

ORLANDI, E. Discurso Fundador. 3ª ed. Campinas: Pontes, 2003.

PANNENBERG, Wolfhart. Teologia Sistemática. vol. 1. São Paulo: Paulus, 2009. 
PANIER, Louis. O discurso de interpretação no comentário bíblico. In: GREIMAS; LANDOWSKI. Análise do discurso em ciências sociais. São Paulo: Global, 1986.

Une lecture Semiotique des textes: questions de theologie biblique. In: Sémiotique et Bible, Lyon, Centre pour l'analyse du discours religieux, n. 56, déc. 1989, p. 19-36.

Sémiotique et etudes bibliques. Évolutions méthodologiques et perspectives épistémologiques. EC - Rivista dell'Associazone Italiana Studi Semiotici, 28 febbraio, 2008. Disponível em : <www.ec-aiss.it>. Acesso em: 04 mar. 2009.

PAULO VI, Papa. Constituição dogmática dei verbum: sobre a revelação divina. In: Bíblia Sagrada. Tradução da CNBB. 6a . ed.São Paulo: Edições CNBB, 2007.

Exortação Apostólica Evangelii Nuntiandi. Sobre a evangelização no mundo contemporâneo. 21 a . ed. São Paulo: Paulinas, 2009.

PEREIRA, Lygia da Veiga. Células-Tronco, Embriões e a Constituição. In: Scientific American Brasil, n. 73, junho de 2008. São Paulo: Duetto, 2008, p. 94.

PONTIFÍCIA COMISSÃO BÍBLICA. A Interpretação da Bíblia na Igreja. $8^{a}$. ed. São Paulo, paulinas, 2009.

PONTIFÍCIO CONSELHO “Justiça e Paz". Compêndio da Doutrina Social da Igreja. Trad. Conferência Nacional dos Bispos do Brasil (CNBB). 4ª ed. São Paulo: Paulinas, 2008.

PERELMAN, Chaïm. Argumentação. In: Enciclopédia Einaudi. Oral/Escrito. Argumentação. vol. 11. Lisboa, Imprensa Nacional-Casa da Moeda, 1984, p. 234-265.

; OLBRECHTS-TYTECA, Lucie. Tratado de argumentação: A nova retórica. São Paulo: Martins Fontes, 2005.

PIETROFORTE, Antônio Vicente. Semiótica visual: os percursos do olhar. São Paulo: Contexto, 2004.

RABAÇA, Carlos Alberto; BARBOSA, Gustavo Guimarães. Dicionário de Comunicação. São Paulo: Ática, 1987.

RAMOS, Dalton Luiz de Paula. Uma nova vida humana começa no exato momento da fecundação. Catolicismo, São Paulo: Padre Belchior de Pontes, n. 689, p.18-20, maio de 2008. Entrevista concedida a Revista Catolicismo.

RAMOS-SILVA, Sueli M. O discurso de divulgação religiosa materializado por meio de diferentes gêneros: dois ethé: duas construções do Céu e da Terra. Dissertação de Mestrado. São Paulo: Universidade de São Paulo, 2007. Disponível em: <http://www.teses.usp.br/teses/disponiveis/8/8139/tde-18102007-145252/>. Acesso em: 26 jun. 2008.

RATZINGER, Cardeal Joseph. Instrução sobre o respeito à vida humana nascente e a dignidade da procriação: respostas a algumas questões atuais. $5^{\text {a }}$ ed. São Paulo: Paulinas, 
2005.

REBOUL, Olivier. Introdução à retórica. São Paulo: Martins Fontes, 2004.

RECTOR, Mônica. Para ler Greimas. São Paulo: Francisco Alves, 1978.

REHFELD, Walter I. Tempo e religião. São Paulo: Perspectiva, 1988.

ROTEIRO PREPARATÓRIO PARA CONFISSÃO. Taboão da Serra: Santuário Santa Teresinha, s.d.

RUBEM ALVES. Perguntaram-me se acredito em Deus. São Paulo: Planeta do Brasil, 2007.

SAUSSURE, Ferdinand de. Curso de Linguística Geral. São Paulo: Cultrix, 2004a. Escritos de Linguística Geral. São Paulo: Cultrix, 2004b.

SAVIOLI, Francisco Platão ; FIORIN, José Luiz. (2004) Lições de texto: leitura e redação.4 ed. São Paulo : Ática.

SILVA, Edvania Gomes da. O ethos nos discursos da Teologia da Libertação e da Renovação Carismática Católica. In: MOTTA, Ana Raquel; SALGADO, Luciana. Ethos discursivo. São Paulo: Contexto, 2008, p. 241-253.

SOUZA, Lindolfo Alexandre de. Marketing católico e a crítica profética: desafios à ação evangelizadora. Aparecida, SP: Editora Santuário, 2011.

STERNBERG, Meir. O jogo das perspectivas na narrativa bíblica: o narrador e Deus. In: AMOSSY, Ruth (org.). Imagens de si no discurso: a construção do éthos. São Paulo: Contexto, 2005, p.185-194.

TATIT, Luiz. Musicando a Semiótica: Ensaios. São Paulo: Annablume, 1997.

Análise semiótica através das letras. São Paulo: Ateliê Editorial, 2001.

THÉRIAULT, Jean-Yves. Quand la Bible s'ouvre à la lecture sémiotique. Protée : Revue Internationale de théories et de pratiques sémiotique, vol. 34, n.1, p. 67-75, 2006.

TIRABOSHI, Juliana; MENAI, Tânia; AQUINO, Guilherme. Religião X Ciência: Mais uma vez, o conflito pega fogo. Galileu, São Paulo: Editora Globo, n. 171, p. 28-41, outubro de 2005.

TRAVAGLIA, Luiz Carlos. Aspecto verbal no português: a categoria e sua expressão. Uberlândia: EDUFU, 2006.

VALÉRY, Paul. Cahiers. tome 1. Paris: Gallimard, 1989.

VIOTTI, Freferico R. de Abranches. Em Recife, tentativa de quebrar a barreira psicológica contra o aborto. Catolicismo, São Paulo, ano LIX, n. 700, p. 40, abril, 2009. 
ZILBERBERG, Claude. L 'essor du poéme: information rythmique. Saint-Maur : Phoriques, 1979.

Figure. In : GREIMAS, Algirdas Julien; COURTÉS, Joseph. Sémiotique : Dictionaire raisonné de la théorie du langage. Vol.II. Paris, Hachete, 1986, p. 91-93.

Relativite du rythme.Théories e pratiques sémiotiques. Proteé. Vol. 18, n.1., 1990.

.Présence de Wölfflin. Nouveaux Actes Sémiotiques 23-24. Pulim, Université de Limoges, 1992. 1996.

.Signification du rythme et rythme de la signification. In: DEGRÉS n. 87. Bruxelles,

.Remarques sur l'assiete tensive du rythme. 2001. Disponível em: http://www.claudezilberberg.net/download/downset.htm. Acesso em: 3 outubro 2007.

As condições semióticas da mestiçagem. In: Cañizal, E. P. \& Caetano, K. E. (orgs.)

O olhar à deriva: mídia, significação e cultura. São Paulo: Annablume, 2004, p. 69-101.

Elements de grammaire tensive. Limoges: Pulim, 2006a.

2006b.

.Razão e poética do sentido. São Paulo: Editora da Universidade de São Paulo,

.Síntese da gramática tensiva. Significação, São Paulo, n. 25, p.163-204, 2006c.

Louvando o acontecimento. Revista Galáxia, São Paulo, n.13, p. 13-28, jun. 2007.

Glossaire de Sémiotique Tensive. Disponível em :

<http://claudezilberberg.net/glossaire/glossairesetA.htm. Acesso em : 1 julho 2009. 